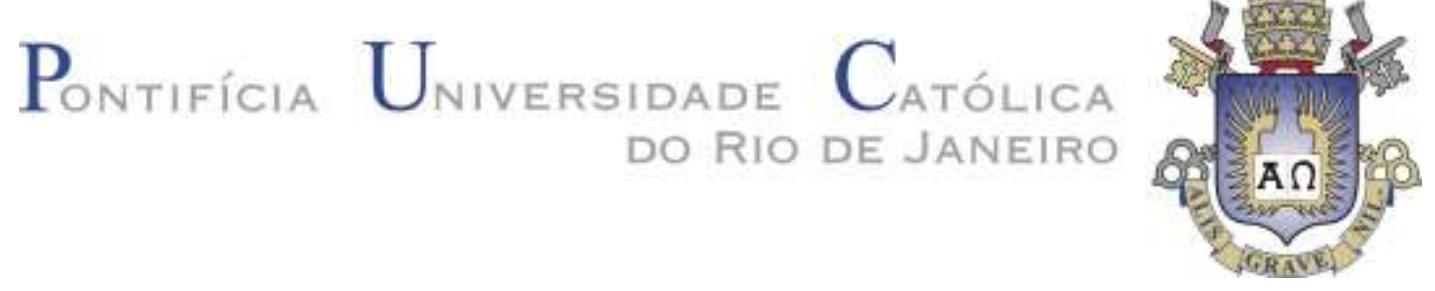

Magnólia Grangeiro Quirino

\title{
UMA PROPOSTA DE MODELO CONCEITUAL PARA A PRODUÇÃO DO AÇAÍ NO ESTADO DO AMAZONAS.
}

Tese de Doutorado

Tese apresentada ao Programa de Pós-graduação em Design como requisito parcial para obtenção do grau de Doutor em Design.

Orientadora: Prof. ${ }^{\text {a }}$ Luiza Novaes Co-orientador: Prof. Fernando Betim Paes Leme 


\section{UMA PROPOSTA DE MODELO \\ CONCEITUAL PARA A PRODUÇÃO \\ DO AÇAÍ NO ESTADO DO AMAZONAS.}

Tese apresentada ao Programa de Pós-Graduação em Design como requisito parcial para obtenção do grau de Doutor em Design. Aprovada pela comissão Examinadora abaixo assinada.

Prof. - Luiza Novaes

Orientador

Departamento de Artes \& Design - PUC - Rio

Prof. Fernando Betim Paes Leme

Co-orientador

Departamento de Arquitetura e Urbanismo - PUC - Rio

Prof. a Jackeline Lima Farbiarz Departamento de Artes \& Design - PUC - Rio

Prof. Wagner Braga Baptista Universidade Federal da Paraíba - UFPB

Prof. Roberto Verschleisser Universidade Estadual do Rio de Janeiro - UERJ

Prof. Alexandre Farbiarz Universidade Federal Fluminense - UFF

Profa. Monah Winograd Coordenadora Setorial do Centro de Teologia e Ciências Humanas 
Todos os direitos reservados. É proibida a reprodução total ou parcial do trabalho sem autorização da universidade, da autora e do orientador.

\section{Magnólia Grangeiro Quirino}

Designer e professora. Mestrado em Engenharia Civil na Universidade Federal do Amazonas - UFAM em 2010, na linha de pesquisa de Materiais não convencionais. Especialização em Meio Ambiente e Políticas Públicas na Faculdade Cathedral de Ensino Superior em 2003. Graduação em Desenho Industrial na Universidade Federal de Campina Grande - UFCG em 1994. Participação em Congressos na área de Design e materiais sustentáveis. Palestrante no evento: "4th Amazon Green Materials Meeting". Atualmente é professora do curso de Design da UFAM e coordenadora do Laboratório de Design de Produtos, com pesquisa e ênfase em desenvolvimento de produto de uso.

Ficha Catalográfica

Quirino, Magnólia Grangeiro

Uma proposta de modelo conceitual para a produção do açaí no Estado do Amazonas / Magnólia Grangeiro Quirino ; orientadora: Luiza Novaes ; coorientador: Fernando Betim Paes Leme. - 2016.

249 f. : il. color. ; $30 \mathrm{~cm}$

Tese (doutorado)-Pontifícia Universidade Católica do Rio de Janeiro, Departamento de Artes e Design, 2016.

Inclui bibliografia

1. Artes e Design - Teses. 2. Design sustentável. 3. Geopolítica do Amazonas. 4. Modelo conceitual na produção do açaí. I. Novaes, Luiza. II. Leme, Fernando Betim Paes. III. Pontifícia Universidade Católica do Rio de Janeiro. Departamento de Artes e Desian. IV. Título. 
Aos meus pais, Manoel Quirino Evangelista (in Memoriam) e Helena Grangeiro Quirino, pela educação e pele o carinho.

Ao meu marido, Marcus Vinícius Moreira Vasconcellos, pela compreensão da minha ausência diante de várias viagens para o Rio de janeiro - RJ.

Aos meus queridos filhos, Manoel Quirino Evangelista Neto e Laurino Gomes de Moraes Vasconcellos Neto, pelo incentivo e orgulho.

Aos meus queridos irmãos, Marconi, Marcelo, Mônica, Maria Helena, Marize

e Márcio, pelo exemplo de solidariedade.

Aos meus cunhados, cunhadas, sobrinhos e sobrinhas, pelo apoio e carinho. 


\section{Agradecimentos}

À minha orientadora, professora Dra. Luiza Novaes pela orientação recebida durante essa jornada.

Ao meu coorientador, professor Dr. Fernando Betim pelo incansável apoio e sabedoria em suas orientações.

À Universidade Federal do Amazonas - UFAM pela minha liberação das atividades docentes.

Ao Programa de Pós-graduação em Design da PUC - Rio pela oportunidade oferecida.

À Fundação de Amparo à Pesquisa do Estado do Amazonas - FAPEAM pela bolsa concedida, sem a qual este trabalho não poderia ter sido realizado.

Aos meus colegas da Universidade Federal do Amazonas - UFAM.

Aos meus colegas da Pontifícia Universidade Católica do Rio de Janeiro - PUC Rio.

Aos professores que participaram da banca examinadora.

A todos os professores e funcionários da Pontifícia Universidade Católica do Rio de Janeiro - PUC - Rio pelos ensinamentos e pela ajuda.

Ao professor José Enos Rodrigues pela leitura do documento.

Ao professor Dr. Luiz Eduardo Cid Guimarães pelas informações.

Ao professor Dr. Wagner Braga Batista pelas considerações.

A todos os familiares e amigos que me incentivaram a realizar esta pesquisa. 


\section{Resumo}

Quirino, Magnólia Grangeiro; Novaes, Luiza; Leme, Fernando Betim Paes. Uma proposta de modelo conceitual para a produção do açaí no Estado do Amazonas. Rio de Janeiro, 2016. 249 p, Tese de Doutorado Departamento de Artes e Design, Pontifícia Universidade Católica do Rio de Janeiro.

Esta tese apresenta uma proposta de modelo conceitual para a produção do açaí (Euterpe precatoria) no Estado do Amazonas, a partir de uma reflexão sobre metodologias emergentes de design sustentável. Tais metodologias buscam integrar as dimensões ambiental, econômica e social aos processos de desenvolvimento de produtos. Na pesquisa, conceitos de ecodesign, design social, design participativo, design sustentável e tecnologia apropriada são abordados. Foi realizado um levantamento dos impactos ambientais e sociais observados no modelo produtivo do açaí (Euterpe precatoria) do Amazonas, tendo como objeto de estudo a Cooperativa de Açaí de Codajás, e em seguida foi elaborada uma proposta de modelo conceitual para a produção do açaí na região, buscando responder aos princípios ambientais e priorizar a responsabilidade socioeconômica, visando ao desenvolvimento da região e à melhoria da qualidade de vida dos agricultores envolvidos no processo.

\section{Palavras-chave}

Design sustentável; geopolítica do Amazonas; modelo conceitual na produção do açaí. 


\section{Abstract}

Quirino, Magnólia Grangeiro; Novaes, Luiza (Advisor); Leme, Fernando Betim Paes. (Co-Advisor) A proposal of a conceptual model for the production of açaí in the State of Amazonas. Rio de Janeiro, 2016. 249 p, Doctorate Thesis - Departamento de Artes e Design, Pontifícia Universidade Católica do Rio de Janeiro.

This thesis presents a proposal of a conceptual model for the production of açaí (Euterpe precatoria) in the State of Amazonas, based on a reflection on emerging sustainable design methodologies. These methodologies seek to integrate the environmental, economic and social dimensions into the product development processes. In the research, concepts of ecodesign, social design, participatory design, sustainable design and appropriate technology are addressed. A survey of the environmental and social impacts observed in the açaí (euterpe precatoria) production model of Amazonas was carried out, having the Cooperativa de Acaí de Codajás as the object of study. In the sequence, a conceptual model was proposed for the production of the açaí in the region, seeking to respond to environmental principles and to prioritize socio-economic responsibility, aiming at the development of the region and the improvement of the quality of life of farmers involved in the process.

\section{Keywords}

Sustainable Design; geopolitics of Amazonas; conceptual model for the production of açaí. 


\section{Sumário}

1. Introdução 20

1.1 Contextualização da pesquisa $\quad 22$

1.2 Problema e delimitação da pesquisa 22

$\begin{array}{ll}1.3 \text { Justificativa } & 23\end{array}$

1.4 Hipótese $\quad 24$

1.5 Objetivo Geral $\quad 24$

1.6 Objetivos específicos 25

1.7 Metodologia e estrutura da pesquisa 25

2. Design e sustentabilidade $\quad 27$

2.1 A sustentabilidade nos métodos projetuais 27

2.1.1 Design Orientado ao Meio Ambiente (DfE - Design for 40 Environment)

2.1.2 Análise do Ciclo de vida do Produto - ACV (LCA - Life-Cycle 42 Assessment)

2.2 Delimitação conceitual entre ecodesign, design social, design 44 participativo, design sustentável e tecnologia apropriada

2.2.1 Ecodesign 45

2.2.2 Design social 46

$\begin{array}{ll}\text { 2.2.3 Design participativo } & 47\end{array}$

$\begin{array}{ll}\text { 2.2.4 Design sustentável } & 47\end{array}$

2.2.5 Tecnologia apropriada 48

3. As questões geopolíticas da Amazônia na elaboração de uma 55 proposta de intervenção sustentável do design

3.1 A Zona Franca de Manaus - ZFM 59

3.2 Fundação Amazonas Sustentável - FAZ 62

3.3 Novas formas de entendimento do espaço rural 70

4. Modelo produtivo do fruto do açaí (Euterpe precatoria) 73 
4.1 O fruto do açaí $\quad 73$

4.1.1 Mesocarpo 75

4.1.2 Epicarpo $\quad 75$

4.1.3 Endocarpo 76

4.2 Palmeira do açaí (Euterpe precatoria) 77

$\begin{array}{ll}4.3 \text { Cultivo do açaí } & 78\end{array}$

4.4 Atividades do modelo produtivo do fruto do açaí 81

4.4.1 Colheita do fruto do açaí $\quad 84$

4.4.2 Debulhamento 86

$\begin{array}{ll}\text { 4.4.3 Acondicionamento } & 88\end{array}$

$\begin{array}{ll}\text { 4.4.4 Transporte } & 90\end{array}$

4.4.5 Despolpamento 91

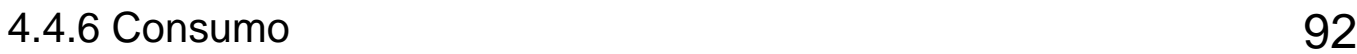

$\begin{array}{ll}\text { 4.4.7 Descarte } & 93\end{array}$

4.5 Pesquisa de campo em Iranduba e Codajás, municípios do 94 Amazonas

4.5.1 O açaí na comunidade de Iranduba 95

$\begin{array}{ll}\text { 4.5.1.1 Comunidade e sustentabilidade } & 98\end{array}$

4.5.2 Município de Codajás: interior do Amazonas 100

4.5.2.1 Levantamento da Cooperativa de Açaí de Codajás 107

4.5.2.2 Levantamento da infraestrutura e equipamentos da 117

Cooperativa de Açaí de Codajás

5. Desenvolvimento de uma proposta de modelo conceitual para a 131 produção do açaí

5.1 Síntese dos critérios para o desenvolvimento do modelo conceitual com base nas metodologias sustentáveis

5.2 Síntese das etapas do modelo conceitual e situações para possível intervenção do design

5.3 Desenvolvimento do modelo conceitual para a produção do açaí 140

$\begin{array}{ll}\text { 5.3.1 Proposta para a colheita do açaí } & 141\end{array}$ 
5.3.3 Proposta para o acondicionamento

5.3.4 Proposta para o transporte

5.3.5 Propostas para o aproveitamento das sementes do açaí

5.4 Considerações sobre o Modelo Conceitual para a Produção do

Açaí no Estado do Amazonas

6. Considerações finais

7. Glossário

8. Referências Bibliográficas

9. Apêndice

Apêndice 1 - Entrevistas realizadas com a presidente da Cooperativa de Açaí de Codajás, a Sra. Franciani Sobreira da Silva Apêndice 2 - Entrevistas realizadas com o Secretário de Cultura de 203 Codajás, o Sr. Ebenézer de Alencar Bastos

Apêndice 3 - Entrevistas realizadas com a vice-presidente da Cooperativa de Crédito Rural e Economia Solidária de Codajás CODCRED, a Sra. Diane Sobreira da Silva

\section{Anexos}

Anexo 1 - Organização das Nações Unidas para o

Desenvolvimento Industrial

Anexo 2 - Organização das Nações Unidas para o 


\section{Lista de figuras}

Figura 1 - Análise do Ciclo de Vida - ACV (Life-Cycle Assessment - $\quad 43$ $L C A)$

Figura 2 - Dimensões territoriais da Zona Franca de Manaus

60

Figura 3 - Prorrogações dos incentivo fiscais da Zona Franca de

62 Manaus

Figura 4 - Mapa das áreas de atuação da FAZ

64

Figura 5 - Núcleo Ângelo Uchôa Bitencourt

64

Figura 6 - Núcleo Assy Manana

65

Figura 7 - Núcleo Uatumã

65

Figura 8 - Núcleo Samuel Benchimol 65

Figura 9 - Núcleo Victor Civita 66

Figura 10 - Núcleo Professor Márcio Ayres 66

Figura 11 - Núcleo Vila Cujubim 66

Figura 12 - Núcleo Bertha Becker 67

Figura 13 - Núcleo Padre João Derickx 67

Figura 14 - Protótipo de "tiradeira" de açaí 69

Figura 15 - Protótipo de "tiradeira" de açaí (simulação de uso) 69

Figura 16 - Fruto do açaí $\quad 69$

Figura 17 - (a) Cacho com frutos do açaí. (b) Cacho sem frutos $\quad 74$ (debulhado)

Figura 18 - Partes do fruto do açaí

Figura 19 - Mesocarpo (polpa) do fruto do açaí 75

Figura 20 - Epicarpo (fibras e casca sobre a semente) 75

Figura 21 - (a) Casca sobre a semente. (b) Casca e fibra extraídas 76 da semente

Figura 22 - Endocarpo (semente do açaí) 76

Figura 23 - (a) Sementes (endocarpo). (b) Sementes beneficiadas 76

Figura 24 - Açaizeiro (Euterpe precatoria) 77

Figura 25 - (a) Palmeira com um estipe. (b) Palmeira touceira 78 
Figura 26 - Área de várzea com sistema consorciado de açaizeiro e 80 bananeira

Figura 27 - Fluxograma representativo do processo de obtenção da 82 polpa de açaí

Figura 28 - Organograma das atividades da cadeia produtiva do

83 açaí

Figura 29 - Extração do cacho na palmeira

84

Figura 30 - (a) Para a retirada dos cachos de açaí, o uso da

85

peconha. (b) Detalhe da peconha

Figura 31 - Debulhamento manual sobre a manta de plástico

87

Figura 32 - Acondicionamento do fruto em cestos e caixas de

88 plástico

Figura 33 - Caixas de plástico

89

Figura 34 - Rasas colocadas nos barcos

90

Figura 35 - Despolpadeira de açaí semi-industrial

91

Figura 36 - Despolpadeira de açaí industrial

92

Figura 37 - Modelo produtivo do açaí com o aproveitamento dos

94 resíduos

Figura 38 Município de Iranduba em destaque na cor vermelha

95

Figura 39 - Plantio de açaí

97

Figura 40 - Localização do município de Codajás no mapa do Amazonas

100

Figura 41 - Principal avenida do município de Codajás 101

Figura 42 - O ícone de Codajás é representado por um extrativista de 102 açaí

Figura 43 - Orla do município de Codajás 102

Figura 44 - Atração da Festa Cultural do Açaí

103

Figura 45 - Centro Cultural de Codajás próximo à orla do município 103

Figura 46 - Acondicionamento dos frutos em sacos de plástico de cinquenta quilos

Figura 47 - Um dos transporte utilizado pelos moradores de Codajás é a bicicleta 
Figura 48 - Cooperativa de Açaí de Codajás e a fábrica de gelo

Figura 49 - Recepção da Cooperativa de Açaí de Codajás

Figura 50 - Esteira rolante que transportar os frutos para a despolpadeira que se encontra na sala de produção

Figura 51 - Entrada da produção da Cooperativa

Figura 52 - (a) Pia quebrada na entrada da produção da

Cooperativa (b) Cartaz ampliado para orientar a higienização das mãos

Figura 53 - Produção da Cooperativa

Figura 54 - Máquina despolpadeira semi-industrial

Figura 55 - Máquina despolpadeira industrial inoperante

Figura 56 - Detalhe da máquina despolpadeira industrial que

transporta as sementes para a área externa da Cooperativa

Figura 57 - Máquina de pasteurização

Figura 58 - Tanques que comportam a polpa para ser embalada

Figura 59 - Sala de controle e qualidade e envase

Figura 60 - Almoxarifado

Figura 61 - Sala de congelamento da polpa

Figura 62 - Porta de saída da câmara de congelamento da polpa

Figura 63 - Escritório da Cooperativa

Figura 64 - (a) Caminhão da Cooperativa. (b) Plataforma motorizada sobre trilho

Figura 65 - O trilho da plataforma vai até o rio Solimões em cuja margem se encontram os fundos da Cooperativa. (a) Trilho da plataforma (b) Limite da Cooperativa com o rio Solimões

Figura 66 - Contêiner da Cooperativa

Figura 67 - Resíduo de sementes acumulados na lateral da

Cooperativa

Figura 68 - Resíduo de sementes utilizados como adubo

Figura 69 - Plantio de açaí (Euterpe precatoria)

Figura 70 - Imagem das palmeiras vistas de baixo para cima 
Figura 71 - Casa de palafita, apropriada para áreas alagadiças

Figura 72 - Açaizeiro de Iranduba. Açaizeiro de Codajás

Figura 73 - Açaizeiro de Codajás.

Figura 74 - Organograma da problemática da Cooperativa de açaí 133 de Codajás

Figura 75 - Organograma para a Cooperativa de açaí de Codajás, com os problemas identificados e estratégias de solução

Figura 76 - Coletor de cacho de açaí feito de madeira com suas variações no sistema de corte

Figura 77 - Protótipo de "tiradeira" de açaí

Figura 78 - Equipamento e Métodos para a Colheita de Cachos de

Frutas

Figura 79 - Primeira etapa do sistema de escada em espiral.

Colocação de fita

Figura 80 - Segunda etapa do sistema de escada em espiral.

Fixação do degrau

Figura 81 - Sistema de escada em espiral finalizado

Figura 82 - Debulhador (pente) para a remoção dos frutos das ráquilas

Figura 83 - Remoção dos frutos das ráquilas com o auxílio do debulhador

Figura 84 - Vagoneta usada no transporte de frutos de açaizeiro 154

Figura 85 - Vagoneta usada no transporte de frutos de açaizeiro 154

Figura 86 - Descarte da cadeia produtiva e aproveitamento dos

resíduos com o aproveitamento das sementes germinativas e não germinativas

Figura 87 - Aproveitamento das sementes como substrato orgânico: 156 terra preta + sementes do açaí + terra preta

Figura 88 - Foto ilustrativa de calçada feita com seixo e argamass

Figura 89 - Homogeneização manual: mistura das sementes do açaí com o adesivo

Figura 90 - Homogeneização mecânica (encoladeira): mistura das 
sementes do açaí com as resinas dentro do recipiente de inox

Figura 91 - Pré-prensa (prensa mecânica) 159

Figura 92a e 92b - (a) Prensa hidráulica da marca Marconi aberta 160 com o colchão e (b) prensa hidráulica descendo a bandeja superior, início da prensagem

Figura 93a e 93b - (a) Painel finalizado sobre a bandeja metálica e 160

(b) pronto para o período de estabilização (cura)

Figura 94 - Organograma do modelo conceitual para a produção do 162 açaí

Figura 95 - Organograma das propostas para desenvolvimento da 163 Cooperativa de açaí de Codajás com as melhorias

Figura 96 - Desenho ilustrativo do modelo de açaí vigente 167

Figura 97 - Desenho ilustrativo da proposta de modelo conceitual 169 para a produção do açaí no Estado do Amazonas. 


\section{Lista de tabelas}

Tabela 1 - Características das metodologias emergentes 52 sustentáveis

Tabela 2 - Legenda da Figura $2 \quad 63$

Tabela 3 - Melhorias: técnicas, ambientais, sociais e culturais do 170 modelo conceitual para a produção do açaí 


\section{Lista de abreviaturas}

ABCV - Associação Brasileira de Ciclo de Vida

ACM - Aterro Controlado de Manaus

ACV - Análise do Ciclo de Vida

ADCT - Ato das Disposições Constitucionais Transitórias

ALCs - Áreas de Livre Comércio

APA - Área de Proteção Ambiental

CODCRED - Cooperativa de Crédito Rural e Economia Solidária de

Codajás.

CREDSOL - Instituição de Crédito Solidário

DfA - Design for Assembly - Design Orientado para Montagem

DfD - Design for Disassembly - Design Orientado para Desmontagem

DfE - Design for Environment - Design Orientado para o Meio Ambiente

DfM - Design for Maintenance - Design Orientado para Manutenção

DfR - Design for Reciclability - Design Orientado à Reciclagem

DfS - DfS - Design for Service - Design Orientado ao Serviço

EEA - European Environment Agency

EMBRAPA - Empresa Brasileira de Pesquisa Agropecuária

FAS - Fundação Amazonas Sustentável

FLOREST de Maués - Floresta de Maués

GDDS - Industrial Design and Sustainable Development Group

IBGE - Instituto Brasileiro de Geografia e Estatística

ICSID - International Council Society Industrial Design

IDAM - Instituto de Desenvolvimento Agropecuário e Florestal Sustentável

do Estado do Amazonas

ISO - International Standardization for Organization

LCA - Life-Cycle Assessment

LMO - Licença Municipal de Operação

NCS - Núcleos de Conservação e Sustentabilidade

ONU - Organização das Nações Unidas 
OSCIP - Organização da Sociedade Civil de Interesse Público

PNUD - Programa das Nações Unidas para o Desenvolvimento

RDS - Reserva de Desenvolvimento Sustentável

RESEX - Reservas extrativista

UNIDO - Organização das Nações Unidas para o Desenvolvimento

Industrial

WDSD - World Design Science Decade

ZFM - Zona Franca de Manaus 
Só compreendemos um universo modelado por nós mesmos.

Nietzche 


\section{Introdução}

O tema desenvolvimento sustentável tem gerado vários debates, expandindo-se para diversas áreas profissionais e, até mesmo, para o cotidiano das pessoas. Na atualidade, o desenvolvimento sustentável é reconhecido oficialmente em agenda política internacional.

Para o entendimento de Manzini (2008. p. 27), o conceito sustentável é um processo que compreende viver melhor consumindo menos e recuperando a qualidade do ambiente. A sustentabilidade, colocada nestes termos, transmite a ideia de ser um processo simples, mas na verdade requer um aporte estratégico que, por sua vez, empreende ruptura de hábitos, que é algo complexo de ser realizado e que demanda tempo.

O tema da sustentabilidade gera abordagens e visões diferentes, e um denominador comum entre elas se mostra um objetivo ainda distante de ser alcançado. O desenvolvimento sustentável provoca divergências para os modelos de expansão econômica: de um lado, estão os expansionistas que buscam o crescimento da economia em detrimento do meio ambiente; e do outro lado, estão os que almejam um modelo econômico equilibrado entre aspectos econômicos, sociais e ambientais.

Neste sentido, a sustentabilidade tem sido objeto de discussões a respeito do meio ambiente e seus parâmetros produtivos, que envolvem neste contexto a economia e o campo social. O design reúne esforços para fazer parte desta conjuntura.

A conexão entre o design e o campo social é discutida há um bom tempo e vem se consolidando, após o ano de 1972, com o livro de Victor Papanek intitulado: Design for the Real World. O design sempre visitou o campo social, embora de modo discreto. Esta conexão convergia para o atendimento às necessidades especiais de idosos, pobres e portadores de deficiências. Estas solicitudes foram aumentando e tornando imperativo uma mudança para aproximar, efetivamente, a prática projetiva do design ao campo social.

Segundo Eichenberg e Reyes (2014. p. 2), o design foi utilizado para reforçar o atual sistema econômico, voltado para a sociedade de consumo, agora investiga estratégias sustentáveis. No campo do design, tais estratégias estão representadas pelas metodologias do ecodesign, do design social, do design 
participativo, do design sustentável e junta-se a este grupo a tecnologia apropriada. Estas metodologias estabelecem afinidades com as ciências sociais.

Existe um esforço em dinamizar a retórica sustentável do design e, para tal, é colocado o humanismo, no sentido de conduzir a atividade projetual com propostas emancipatórias a favor do empoderamento dos grupos sociais.

Cabe um estudo mais profundo nestas metodologias, assinalando suas semelhanças e divergências, de forma a perceber as fronteiras de cada uma e a interface com sustentabilidade. Deste modo, o design vai consolidando seus parâmetros sustentáveis para formatar uma proposta de um modelo conceitual para a produção do açaí inserido no estado do Amazonas.

Para entender a dinâmica da sustentabilidade no Amazonas é necessário um estudo mais específico. É colocada a geopolítica da Amazônia para auxiliar no entendimento da relação do poder público e do espaço geográfico com o processo de povoamento. São delineados os diversos fatores que contribuíram para o desenvolvimento econômico do estado do Amazonas. Neste contexto geopolítico, é configurado um cenário complexo.

Apesar da complexidade e dificuldades encontradas no estado do Amazonas, é possível implementar iniciativas que são referências de modelos sustentáveis em cenários complexos. Estes modelos estão sendo implementados no interior do estado do Amazonas coordenados pela Fundação Amazonas Sustentável - FAS, assim como, pela Zona Franca de Manaus - ZFM.

A FAS surgiu em 2007, e desde então vem apresentando resultados significativos nos âmbitos social, político, educacional e da saúde para as comunidades ribeirinhas e comunidades afastadas.

A ZFM iniciou suas atividades no ano de 1957, com dois grandes objetivos: promover a ocupação da Amazônia Ocidental e garantir segurança para a integridade desta região; e estabelecer um modelo econômico com ênfase no incentivo fiscal para a consolidação de um polo industrial, comercial e agropecuário nesta região. De acordo com Rios (2015. p. 24), a Zona Franca de Manaus é reconhecida como estratégia de desenvolvimento regional eficaz que realizou uma base econômica sólida na Amazônia Ocidental. Devido a esta credibilidade o governo federal vem prorrogando os prazos de vigência de incentivo fiscal, contribuindo para que a ZFM não seja extinta. 


\section{1}

\section{Contextualização da pesquisa}

A partir de meados do Século XX, o meio ambiente vem sendo observado mais intensivamente, sendo apresentados alguns sinais que se tornam primordiais para traçar um paralelo entre a expansão econômica e as melhorias sociais. Neste sentido, várias profissões possuem uma parcela de responsabilidade quanto às questões socioambientais. Nós, como designers, atuamos diretamente na melhoria da qualidade de vida das pessoas, portanto, não estamos fora desta responsabilidade.

Este paralelo entre a expansão industrial e as melhorias sociais é processado por meio da equalização dos conceitos ambientais, econômicos, sociais e políticos. Neste sentido, o conjunto destas variáveis torna-se maior quando tratado no estado do Amazonas, devido a sua grandeza territorial.

O design sustentável busca estabelecer estratégias para obter resultados simples e que possam ser replicados, possibilitando minimizar as grandes distâncias geográficas presentes no Amazonas.

Neste cenário, esta pesquisa apresenta um estudo sobre possibilidades de atuação do design no Estado do Amazonas, considerando princípios de sustentabilidade. Daí ser relevante que estas estratégias estejam fundamentadas na valorização da cultura local, na interpretação do discurso da comunidade e, por fim, na ponderação da aquisição e uso dos recursos naturais.

\section{2}

\section{Problema e delimitação da pesquisa}

Um modelo conceitual para a produção do açaí no Estado do Amazonas, um estado de grande extensão territorial que faz fronteira com três países Colômbia, Venezuela e Peru - além de fazer fronteira com os estados de Roraima, Pará, Mato Grosso, Rondônia e Acre se apresenta como proposta pertinente, por sua complexidade. Isso porque estas fronteiras implicam em transações econômicas conjugadas sob diferentes normas, contribuindo para um desenvolvimento econômico interno atribulado de divergências. Portanto, é neste complexo cenário que esta pesquisa transcorre. Na tentativa de elucidar essa dinâmica econômica, é colocada em pauta a geopolítica do estado do Amazonas, que compreende vários aspectos, dentre eles, o processo de povoamento do 
estado e seu desenvolvimento econômico. Um foco nesse processo se volta para a ocupação das margens dos rios Negro, Solimões-Amazonas, Madeira, Purus e Juruá, entre outros, que se mostra bastante complexa. Apesar de a população indígena ter participado deste processo de ocupação ribeirinha, o que marcou a região foi a exploração comercial e exportação da borracha. $E$ foi este fenômeno que impulsionou o desenvolvimento econômico do estado do Amazonas.

A partir da década de 1950, o Amazonas passou a fazer parte do audacioso projeto de integração nacional, e, como em todo grande projeto, ocorreram impactos ambientais e sociais. Segundo Becker (2005. p. 3), os aspectos positivos podem ser exemplificados com a construção de estradas, como a Transamazônica, a Perimetral Norte, a Cuiabá/Santarém, além da implantação de redes de comunicação.

Apesar da complexidade geopolítica do Amazonas, a ocorrência de iniciativas sustentáveis tem sido relatada com bons resultados, levando-nos a crer que é possível e desejável a implementação de projetos sustentáveis na região. Com base nesta assertiva, surge a proposta de desenvolvimento de um modelo conceitual para a produção do açaí.

Considerando que a cadeia produtiva do açaí transita entre duas áreas, a rural e a urbana, verifica-se que algumas ações da cadeia são realizadas em locais diferentes, muitas vezes, iniciadas na floresta e finalizadas na cidade. Isso acarreta um deslocamento entre estas áreas, o que se apresenta como um desafio complexo, uma vez que envolve transporte fluvial e rodoviário.

O modelo produtivo existente, sob a análise da Cooperativa de açaí de Codajás, conta com um pessoal desmotivado e desinteressado para as atividades relacionadas com a comercialização do açaí; e um maquinário de ponta em estado de manutenção comprometido.

Este modelo apresenta, desta forma, padrões adaptados conforme a realidade local, implicando um conjunto de ações improvisadas, que resultam em um modelo não sistemático. Fica evidente, portanto, a necessidade de uma revisão do modelo tradicional para torná-lo sustentável.

\section{3}

\section{Justificativa}

A bibliografia disponível a respeito da cadeia produtiva do açaí se mostra ainda bastante incipiente. Verifica-se, contudo, que a literatura a respeito do valor nutricional da polpa do açaí é bastante ampla. Em vários aspectos, esta literatura 
favorece a economia regional e consolida o consumo e os mercados nacional e internacional do açaí.

Assim, os esforços desta pesquisa são no sentido de apresentar um estudo referente ao desenvolvimento de uma proposta de modelo conceitual para a produção do açaí no Estado do Amazonas.

Para realizar esse estudo, que trata de uma ação de design no meio ambiente, inicialmente apresentamos alguns conceitos de design que envolvem metodologias sustentáveis emergentes: ecodesign, design social, design participativo e design para sustentabilidade.

Esta abordagem colabora para a discussão das diretrizes metodológicas com ênfase em fundamentos de sustentabilidade, ressaltando, desta forma, a importância do estudo para o campo acadêmico do design. Ao mesmo tempo, a aplicabilidade de uma metodologia sustentável é, também, de grande interesse para a agroindústria. Assim, a contribuição deste estudo, tanto para o setor acadêmico, quanto para o setor comercial profissional, fica evidenciada.

Pode-se dizer, portanto, que dois motivos justificam a realização desta pesquisa: a escassez de literatura acerca do aproveitamento integral do açaí e de um modelo conceitual inspirado em princípios de sustentabilidade para a produção do açaí no Estado do Amazonas. Sem dúvida, a possibilidade de colaborar com pesquisas em design orientadas para a área da sustentabilidade, favorece tanto a academia, quanto a indústria.

\section{4}

\section{Hipótese}

A utilização de metodologias emergentes de design sustentável na elaboração de uma proposta de modelo conceitual para a produção do açaí no Estado do Amazonas impacta não apenas nas fases do processo produtivo do açaí e suas técnicas e tecnologias, como também na fase de entressafra.

\section{5}

\section{Objetivo Geral}

Propor um modelo conceitual para a produção do açaí no Estado do Amazonas considerando as relações entre design, o campo social e as metodologias emergentes de design sustentável. 


\section{6}

\section{Objetivos específicos}

- Estabelecer relações entre o design e o campo social;

- Discutir metodologias emergentes de design sustentável;

- Entender a complexidade geopolítica do estado do Amazonas;

- Identificar exemplos de modelos sustentáveis realizados no Amazonas;

- Investigar as etapas da atual cadeia produtiva do açaí no Amazonas;

- Apontar entraves presentes na atual cadeia produtiva do açaí no Amazonas;

- Propor otimizações para as etapas da cadeia produtiva do açaí no Amazonas;

- Desenvolver uma propostas de modelo conceitual e atividades para a produção do açaí no Estado do Amazonas.

\section{7}

\section{Metodologia e estrutura da pesquisa}

Na primeira etapa da pesquisa, é realizada uma revisão bibliográfica para levantamento e consolidação de referencial teórico sobre design sustentável; Design for Environment - DfE; Análise do Ciclo de Vida - ACV; metodologias emergentes de design sustentável; geopolítica do Amazonas e sobre a cadeia produtiva do açaí no estado do Amazonas. A pesquisa se concentra em livros, periódicos, sítios eletrônicos e anais de congresso, tendo como objetivo a fundamentação da tese.

Na segunda etapa da pesquisa, que compreende o desenvolvimento da tese propriamente dita, optou-se pela pesquisa exploratória. Primeiramente, o método exploratório é empregado na observação do atual modelo produtivo do açaí no Amazonas, a fim de entender sua dinâmica e conhecer os atores envolvidos neste processo. Em seguida, busca-se pontuar os impactos ambientais desse modelo com o propósito de avaliar ações mitigadoras e propor um modelo conceitual para a produção do açaí.

Pelo exposto, esta pesquisa emprega os métodos bibliográfico e exploratório. 
A tese está organizada em seis capítulos. O primeiro capítulo apresenta o escopo geral do trabalho, os objetivos almejados e sua contribuição. Trata da introdução com as subseções: Contextualização da pesquisa, Problema e delimitação da pesquisa, Justificativa, Hipótese, Objetivo geral, Objetivos específicos, Metodologia da pesquisa e, por fim, a Estrutura da pesquisa.

O segundo capítulo aborda o Design e sua interface com a sustentabilidade, abordando o Design Orientado ao Meio Ambiente (Design for Environment - DfE); a Análise do Ciclo de Vida - ACV (Life-Cycle Assessment LCA); e conceitos de ecodesign, design social, design participativo, design sustentável e tecnologia apropriada.

O terceiro capítulo traz um breve panorama da complexidade geopolítica da região do Amazonas tendo em vista o desenvolvimento de uma proposta de intervenção de design sustentável; e apresenta os modelos sustentáveis da Zona Franca de Manaus - ZFM e da Fundação Amazonas Sustentável - FAS, ambos utilizados como referência na pesquisa.

O quarto capítulo versa sobre a cadeia produtiva do fruto do açaí (Euterpe precatoria) e suas principais etapas.

O quinto capítulo, apresenta uma proposta de modelo conceitual para a produção do açaí para o Estado do Amazonas.

O sexto capítulo compreende as considerações finais referentes à pesquisa e aos resultados obtidos. 


\section{2.}

\section{Design e sustentabilidade}

Neste capítulo, são abordadas metodologias de design, enfocando suas interfaces com a sustentabilidade e com as ciências sociais. Desta forma, conceitos de ecodesign, design social, design participativo e tecnologia apropriada são apresentados, e uma articulação desses conceitos é elaborada a fim de se definir o conceito de metodologia de design sustentável utilizado ao longo da tese.

\section{1}

\section{A sustentabilidade nos métodos projetuais}

Inicialmente, será descrito o percurso histórico do desenvolvimento sustentável com a finalidade de entendermos a trajetória do design neste contexto e sua responsabilidade nos métodos projetuais.

O surgimento do desenvolvimento sustentável tem sua origem no Clube de Roma, um projeto ambicioso que, em 1968, propôs avaliar os problemas da magnitude do sistema social, os quais, segundo Margolin (1996. p.1), abrangem a pobreza, o dano ambiental, o aumento desordenado da urbanização, a instabilidade no emprego, a desconfiança nas instituições, a alienação da juventude, a recusa dos valores tradicionais, a inflação, entre outras rupturas econômicas e monetárias.

O primeiro relatório produzido para o Clube de Roma por um grupo de pesquisadores do Massachusetts Institute of Technology, foi publicado em 1972, quatro anos depois, intitulado Os limites do crescimento (The limits to growth). $\mathrm{O}$ relatório questionava a viabilidade do crescimento contínuo sem que houvesse a imposição de limites para se alcançar um estado de equilíbrio global entre a população e a produção de bens materiais. Este feito só é possível mediante reavaliação dos seguintes fatores: crescimento da população; produção agrícola; produção industrial; esgotamento de recursos não renováveis; e geração de poluição.

O desenvolvimento sustentável, ao longo dos anos, tomou uma amplitude conceitual que fez surgir o termo sustentabilidade. Segundo Manzini (2008. p. 21), o termo foi usado pela primeira vez em 1987, no documento coordenado por Gro 
Harlem Brundland para a Comissão Mundial para o Ambiente e o Desenvolvimento, denominado Nosso Futuro Comum (Our Common Future). A partir desta data, o termo foi utilizado com frequência, inclusive na Conferência das Nações Unidas sobre Ambiente e Desenvolvimento realizada no Rio de Janeiro, em 1992. Conferência conhecida também como Cúpula da Terra, ECO92 e Conferência do Rio de Janeiro.

Desde então, surgiram vários estudos e comissões com o propósito de endossar o desenvolvimento sustentável, fazendo com que o tema se tornasse reconhecido oficialmente em agenda política internacional.

No campo do design o repertório sustentável foi marcado pelo trabalho de alguns designers e programas que valem a pena serem lembrados.

$\mathrm{Na}$ década de 70 , houve preocupação com os aspectos econômicos e sociais, direcionando os projetos de design para a redução de materiais e para as comunidades carentes. Nestes moldes, surge o termo design social. O design social foi reiterado com o livro de Victor Papanek, Design for the real world, lançado em 1972.

Neste livro, Papanek ressaltou sua preocupação com as comunidades pobres e projetos direcionados às necessidades especiais do indivíduo. Também, criticou a irresponsabilidade dos designers do Primeiro Mundo que se mostraram indiferentes à criação de objetos inúteis e perigosos à sociedade.

O autor, em sua trajetória, foi enfático sobre a importância de projetos voltados para as comunidades pobres e que utilizassem tecnologia de baixo custo. Na opinião de Margolin (2015. p. 17), esta ênfase acabou colaborando para associar o design somente a projetos para comunidades carentes, impedindo 0 poder público de enxergar a capacidade do design para elaborar estratégias a favor do desenvolvimento econômico.

Alguns teóricos consideram o trabalho de Papanek restrito a questões sociais. Compartilho da opinião que a ênfase de Papanek nas questões sociais, na época da publicação de seu livro, influenciou fortemente o design no Brasil, fazendo com que as questões econômicas e sociais fossem tratadas com mais afinco e os aspectos ambientais e culturais fossem menos abordados. A visão de Papanek se adequava aos temas vigentes daquele época. Contudo, a abrangência da demanda atual da sustentabilidade exige que além dos aspectos econômicos e sociais, o design sustentável inclua os aspectos ambientais e culturais.

Observo que alguns designers foram visionários, enquanto outros ficaram focados na problemática de seu tempo. Neste sentido, podemos dizer que 
Papanek foi um designer engajado com os problemas do seu tempo, sem que isto tire o mérito dos seus esforços. Avalio a contribuição de Papanek, que propagou a relevância do design social, significativa para a construção do corpo teórico do design sustentável no contexto atual.

Papanek apud Margolin (2015. p. 18), em seu polêmico livro: Design for the real world, declara uma oposição binária entre "a irresponsabilidade e o desperdício de produtos criados pelos designers do Primeiro Mundo e os produtos mais significativos que ele e seus alunos haviam projetado para usuários do Terceiro mundo". Entendo que a oposição binária é uma crítica quanto a falta de compromisso dos designers do Primeiro Mundo com os aspectos ambientais e sociais. Por outro lado, o Papanek ressalta os trabalhos que são de sua autoria como projetos sociais que devem ser replicados para os países pobres.

Margolin (2015. p. 17) defende a teoria de que o trabalho de Papanek contribuiu para associar o design a projetos de baixa tecnologia e à sobrevivência das comunidades, impedindo as autoridades de enxergarem a competência do design para elaborar estratégias para o desenvolvimento econômico. Para mim, acrescento ainda o desconhecimento por parte das autoridades a respeito das metodologias de design. A partir do momento em que o poder público entender as metodologias e a abrangência do design irá perceber sua relevância para o desenvolvimento econômico. O design pode ter atuação marcante na elaboração de estratégias para o desenvolvimento industrial e este é o caminho para o desenvolvimento econômico.

Neste sentido, segundo Patrocínio (2015. p. 12), houve uma preocupação com o desenvolvimento econômico nos países em desenvolvimento que levou o Conselho Internacional das Sociedades de Desenho Industrial - ICSID a pedir a Gui Bonsiepe, no ano de 1973, a preparação do documento intitulado Desenvolvimento pelo Design, direcionado para a Organização das Nações Unidas para o Desenvolvimento Industrial - UNIDO.

De acordo com Patrocínio (2015. p. 12), em 1975 os dois órgãos, ICSID e UNIDO, prepararam outro documento intitulado Diretrizes Básicas para Políticas de Design Industrial em Países em Desenvolvimento (Basic Guidelines for Policy of Industrial Design in Developing Countries).

Os dois documentos citados acima foram incluídos no livro Design e Desenvolvimento: quarenta anos depois, organizado por Gabriel Patrocínio e José Mauro Nunes, e encontram-se reproduzidos na íntegra nos anexos deste trabalho. 
No documento Desenvolvimento pelo Design, uma das discussões apresentadas diz respeito à distinção entre os países em desenvolvimento e os países industrializados, distinção esta que por si só já justifica a necessidade de políticas econômicas voltadas para a industrialização nos países em desenvolvimento. A situação apresentada evidencia que nos países industrializados existe uma demanda menor do que a sua força produtiva, ao passo que nos países em desenvolvimento existe uma demanda maior do que a de seus meios produtivos. Isso significa que o setor industrial nos países industrializados responde às necessidades com o aporte industrial em vantagem, ao passo que nos países em desenvolvimento, há a necessidade de se consolidar a indústria para melhor atender a nação.

Ainda em subitem do documento que trata sobre o papel específico do design industrial em países em desenvolvimento, são ressaltados dois aspectos que merecem atenção: a criação de empregos para promover as atividades produtivas; e a orientação a respeito dos recursos limitados que devem ser utilizados de forma otimizada evitando o desperdício.

Destaco estes dois itens, a criação de empregos e a limitação dos recursos, pois ambos foram observados durante a pesquisa de campo realizada na Cooperativa de Açaí de Codajás, que será tratada no capítulo cinco desta tese.

O documento Diretrizes Básicas para Políticas de Design Industrial em Países em Desenvolvimento traz, por sua vez, recomendações que funcionam como diretrizes para o crescimento industrial em países em desenvolvimento. As recomendações presentes neste documento foram elaboradas pela Secretaria da UNIDO, com o envolvimento do ICSID e de agências nacionais e internacionais em países em desenvolvimento.

Em razão das diferenças e especificidades existentes em cada país, são necessárias adaptações, derivadas a partir destas diretrizes. Neste sentido, o documento é visto como um modelo padrão, permitindo reajustes conforme as necessidades.

O documento está estruturado em três grandes grupos: o lugar do design industrial no desenvolvimento; objetivos e requerimentos e áreas de atuação; e componentes dos programas de desenvolvimento do design industrial.

O primeiro grupo aborda a atuação do design, ressaltando seu componente de inovação tecnológica; sua localização em programas de assistência tecnológica; sua característica de atividade de planejamento; sua política de diversificação de produtos e transferência de tecnologia. 
O segundo grupo apresenta recomendações considerando questões de mercados locais, substituição de importações, mercados de exportação, trabalho intensivo, produção alimentícia, compatibilidade ambiental, tecnologia "apropriada", e utilização de capacidades de produção existentes.

Destaco nesse grupo três pontos que também guardam relação com a problemática da Cooperativa de Açaí de Codajás, e que de certa forma serviram como princípios norteadores para o modelo conceitual para a produção do açaí que será tratado no capítulo cinco. São eles: o estudo em todos os extratos sociais considerando as possíveis restrições tecnológicas, culturais e econômicas; a aproximação do design com a tecnologia apropriada; e a valorização de programas de baixo custo e preservação de procedimentos produtivos existentes.

Tanto o documento Desenvolvimento pelo Design como o documento Diretrizes Básicas para Políticas de Design Industrial em Países em Desenvolvimento são documentos direcionados para a industrialização, porém estão citados neste trabalho por dois motivos: o primeiro é a afinidade e pertinência das recomendações em relação aos problemas da Cooperativa de Açaí de Codajás e o segundo motivo é a conexão com o design sustentável.

Segundo Margolin (2015. p.17), a junção dos dois órgãos, o ICSID e a UNIDO, colaborou para a formação da Declaração de Ahmedabad, organizada pelo Instituto Nacional de Design da Índia, no ano de 1979. Esta Declaração teve por objetivo discutir o agenciamento do design em países em desenvolvimento.

A Declaração Ahmedabad prioriza o design como estratégia para o planejamento econômico, e considera que o design é capaz de melhorar a qualidade de vida nos países em desenvolvimento. Para tal, ressalta a importância de se observar determinadas características dos países em desenvolvimento, como por exemplo, suas habilidades, seus materiais, suas tradições indígenas e revela que junto a estes itens é positivo inserir o poder da ciência e da tecnologia.

Seguem a estes documentos inúmeras discussões e por volta da década de 1980, conforme Margolin (2015. p. 14), o cerne da questão foi ampliado do nível econômico para o nível do bem-estar humano. Desta forma, outros vetores como saúde, cultura, educação, e equidade social entre outros ganham relevância e são inseridos nas discussões, por meio do Programa das Nações Unidas para o Desenvolvimento - PNUD, que acatou o conceito de Desenvolvimento Humano.

Um programa que vale a pena ser mencionado, segundo Margolin (2014. p.124), é o World Design Science Decade - WDSD que estabelece o papel do designer perante os grandes problemas mundiais entre as décadas de 1965 até 
1975. O documento do WDSD teve a colaboração do escritor, designer e arquiteto Richard Buckminster Fuller, que tomou como base os princípios do desenvolvimento sustentável. O WDSD é enfático na questão dos recursos energéticos mundiais, no uso eficiente dos recursos naturais e dos metais e na integração da máquina-ferramenta em sistemas eficientes em produção industrial.

Fuller concentrou seus estudos na investigação da relação entre os recursos naturais e as necessidades da humanidade. Acreditava que era possível alcançar mais qualidade de vida com menos recursos naturais. Por ser considerado um homem à frente do seu tempo, devido a seus inventos e à sua ampla pesquisa, tinha como finalidade antecipar as dificuldades e encontrar soluções para os problemas globais. Ele definiu o design como Comprehensive Anticipatory Design Science (Ciência Completa e Antecipatória do Design).

Outro relatório que faz parte da história do desenvolvimento sustentável e tem a sua relevância neste contexto é o elaborado durante o evento Agenda 21: $A$ Estratégia da Cúpula da Terra para Salvar Nosso Planeta (The Earth Summit Strategy to Save our Planet) realizado no Rio de Janeiro em junho de 1992. O relatório consiste em documentos, aprovados pela maioria dos chefes de Estado presentes ao evento, que tratam de um diagnóstico minucioso e de severas críticas a respeito dos impactos ambientais. Margolin (2014. p. 126) considera, contudo, que as ações reguladoras para impedir ou minimizar os danos ao meio ambiente foram irrelevantes. O autor reconhece que o documento Agenda 21 ampliou a discussão e deixou um grande legado para a realização de mudanças fundamentadas na sustentabilidade, anunciando uma cultura da sustentabilidade.

Cabe aqui compulsar autores como Frascara, Acselrad, Viana, Sachs, Manzini e Margolin para expor um breve panorama sobre sustentabilidade a partir de algumas de suas definições a respeito do tema.

A sustentabilidade coloca em cheque o grande desafio do século XXI, que trata da polêmica relação entre desenvolvimento econômico e degradação ambiental. Frascara (2002. p. 233) aponta que a proeza deste século consiste em equalizar a infinita ambição do mundo dos negócios com os limites físicos do planeta.

Para Acselrad (2004. p. 1), a sustentabilidade é um discurso emprestado das ciências biológicas que fazem uma analogia entre os processos biológicos e os processos econômicos estruturados pela produção excedente. Esta definição é resumida nas palavras de Acselrad: 
A noção de "sustentabilidade" da Biologia pensou os sistemas vivos como compostos de um "capital/estoque" a reproduzir e de um "excedente/fluxo" de biomassa, passível de ser apropriado para fins úteis sem comprometer a massa de "capital" originário. (ACSELRAD, 2004. p. 2)

Nesta analogia, o autor sugere a apropriação adequada dos recursos naturais (sistemas vivos) e recomenda que este procedimento seja realizado sem danos para o meio ambiente (capital originário). Na minha opinião, um pressuposto que merece atenção, pois permite a extração dos recursos possibilitando a renovação da natureza por meio do seu ciclo biológico.

A definição de sustentabilidade, enriquecida pelas visões da Biologia e da Economia, amplia nosso modo de compreensão de um tema de extensa complexidade. Neste sentido, é bastante adequada a conjugação de vários campos profissionais para endossar o conceito de sustentabilidade, como também para ampliar o conjunto de soluções sobre o tema. Até mesmo em um mesmo campo são apresentados discursos com tônicas diferentes que, por conta disso, trazem importantes contribuições para a interlocução. Podemos citar como exemplo o economista Acserald, que trata a sustentabilidade por caminho diferente do tradicional campo da economia, que a vê como desenvolvimento econômico e o meio ambiente.

A relevância de trazer o discurso de Acselrad para este espaço é justificada pelo fato do autor abordar a sustentabilidade por outro viés, diferente da maioria dos teóricos sobre o tema. Em sua grande maioria, o cerne da sustentabilidade gira em torno dos recursos naturais e da possibilidade da sua finitude. Não dirimindo a importância destes aspectos, Acselrad observa a sustentabilidade priorizando a sociedade. O autor (2004. p. 4) admite que o maior problema da sustentabilidade não está relacionado com o meio ambiente, mas sim em como a sociedade interpreta a aquisição e uso dos recursos naturais.

No entendimento do autor, a sustentabilidade está alicerçada muito mais nas questões sociais do que ambientais. O problema da sustentabilidade não é o meio ambiente, o problema é como a sociedade utiliza o meio ambiente e como estas relações de apropriação dos recursos naturais se configuram no tecido social.

Viana (1999. p. 3), por sua vez, considera que a expressão mais coerente para nomear o fenômeno seria "envolvimento sustentável". Isso porque o termo desenvolver, segundo o dicionário Michaelis apud Viana, corresponde a "tirar o invólucro, descobrir o que estava encoberto". 
O autor alega que algumas ações relacionadas ao desenvolvimento sustentável, como por exemplo a conservação das reservas ambientais, precipitam a saída das populações tradicionais de suas terras. Neste sentido, desenvolver significa tirar a comunidade do seu contexto ambiental, cultural, social e econômico. Nas palavras de Viana:

Por envolvimento sustentável poderíamos entender o conjunto de políticas e ações direcionadas para fortalecer o envolvimento das sociedades com os ecossistemas locais, fortalecendo e expandindo os seus laços sociais, econômicos, culturais, espirituais e ecológicos; com o objetivo de buscar a sustentabilidade em todas essas dimensões. (VIANA, 1999. p. 3)

O autor destaca, ainda, um outro aspecto de suma importância para o "envolvimento sustentável", que é o respeito com o saber das populações tradicionais. Segundo Viana (1999. p. 1), estes conhecimentos, que abrangem a história das florestas, sua variabilidade geográfica, taxonomia, ecologia e usos e manejo das espécies de plantas e animais, colaboram para conservar os ecossistemas naturais de maneira mais efetiva do que o padrão convencional.

Viana recomenda que para conservar os ecossistemas florestais é necessário o envolvimento dos moradores da floresta para elaborar as estratégias ambientais com base nos conhecimentos tradicionais. $O$ autor é responsável pela implementação da Fundação Amazonas Sustentável - FAS que compreende nove Núcleos de Conservação e Sustentabilidade - NCS, doze Reservas de Desenvolvimento Sustentável - RDS, duas Reservas extrativistas - RESEX, uma Área de Proteção Ambiental - APA e uma Floresta Estadual de Maués FLOREST de Maués, que serão tratados no capítulo 3. Para a implementação destas reservas foi necessário se estabelecer regras e normas ambientais, que só foram possíveis de ser traçadas com o envolvimento das comunidades locais. A partir da demanda dos comunitários foram construídas soluções mantendo as tradições culturais, sociais e ambientais. Esta experiência de implementação das reservas proporcionou a Viana a consolidação de seus postulados e, para nós, reiterou a ideia de que o caminho da sustentabilidade é por meio do envolvimento das comunidades.

Já Sachs (2000. p. 32) defende o uso produtivo das reservas florestais a partir dos princípios da sustentabilidade. O autor é a favor da conservação das reservas, mas contrário à manutenção de reservas intocáveis. Sachs ressalta que a base da nossa economia está consolidada na extração dos recursos naturais. Mas, para fazer o uso produtivo das reservas sem degradar o meio ambiente, é necessária a implementação de estratégias específicas. 
Em busca de configurar estas estratégias, Sachs recorre às "pessoas do ecossistema", denominação adotada por Madhav Gadgil e por Ramachandra Guha apud Sachs ( 2009. p. 30 e 43).

As "pessoas do ecossistema" (habitantes das florestas) e a população rural são as pessoas mais indicadas para incorporar tais estratégias, pois fazem uso dos recursos renováveis, respeitando os limites do ciclo da natureza. Para os habitantes das florestas, a questão da territorialidade, ou seja, o sentimento de pertencimento e identidade com o espaço geográfico é um processo intrínseco ao seu modo de vida. Somados a este sentimento, existem, ainda, o conhecimento, o saber tradicional a respeito da natureza e do entorno em que vivem.

O saber dos habitantes da floresta está relacionado com a experiência e com a observação do cotidiano que, por sua vez, configura-se de modo pragmático. Este conhecimento irá ajudar a elucidar estratégias para o uso produtivo nas reservas. Estas estratégias regulam o seu modo de vida simples, factível e eficiente.

Neste sentido, é proclamado o modelo econômico endógeno, no qual são os próprios favorecidos, ou melhor, as "pessoas do ecossistema" que elaboram suas estratégias de uso produtivo e se beneficiam com as suas próprias ideias, diferentemente das estratégias implementadas por pessoas externas àquele território, alheias à realidade local, e que, com base em conhecimento superficial, estabelecem diretrizes para serem compulsoriamente replicadas. A elaboração do modelo endógeno possibilita efetivamente a preservação da biodiversidade, aliada ao respeito à natureza e em busca da equidade social. O modelo endógeno aponta critérios que podem ser implementados no modelo conceitual para a produção do açaí que serão discutidos nos capítulos 4 e 5.

O termo sustentabilidade apresenta outras dimensões, segundo Sachs (2009. p. 71), além da dimensão ambiental. A sustentabilidade abrange a responsabilidade social, cultural, territorial, econômica e políticas públicas. Sachs (2009. p. 85) acrescenta a estas dimensões critérios de sustentabilidade. $\mathrm{Na}$ esfera social, o objetivo é encontrar a homogeneidade entre os grupos, proporcionar qualidade de vida e acesso aos serviços sociais. Na dimensão cultural, o desafio consiste em manter o equilíbrio entre o respeito à tradição e à inovação. Na dimensão territorial, o objetivo é priorizar tanto a configuração urbana quanto a rural, otimizando o ambiente urbano e o encontro de soluções para as diferenças regionais. No âmbito econômico, o destaque se concentra na segurança alimentar, na inovação e na modernização do ferramental da 
produção. Por fim, na dimensão política são abordadas a união social e a possibilidade de desenvolvimento de tecnologia .

Percebo uma afinidade entre os autores Viana e Sachs, no que diz respeito à conservação da floresta em pé, quando ambos defendem este princípio intermediado pelo envolvimento dos habitantes da floresta. Viana preocupa-se com os procedimentos que são implementados para a obtenção da conservação da floresta, ele recomenda que haja uma interlocução na elaboração das estratégias com os envolvidos. Sachs acata esta prática através do uso produtivo da natureza, ou melhor, aprova o uso dos recursos naturais respeitando os limites do ambiente. Sachs é enfático na conservação da floresta, mas discorda da visão de mantê-la intocável.

Para Manzini (2008. p.19), a introdução do conceito de desenvolvimento sustentável é marcada pela reformulação dos modelos econômicos dos países ricos. Países com uma economia voltada para a industrialização, na qual se vislumbra o capital financeiro em detrimento do meio ambiente; onde se desprezam os limites da recuperação dos ecossistemas; onde a produtividade industrial prevalece sobre o meio ambiente. Em síntese, o avanço industrial adotado pelos países ricos segue um modelo econômico desajustado ambiental e socialmente. Apesar da ineficiência deste padrão, ele ainda é colocado como referência de desenvolvimento econômico para países pobres. Neste sentido, Manzini propõe mudanças para os sistemas político e econômico, além da ruptura com os procedimentos adotados pela indústria. Portanto, afirma:

A sustentabilidade requer uma descontinuidade sistêmica: de uma sociedade que considera o crescimento contínuo de seus níveis de produção e consumo material como uma condição normal e salutar, devemos nos mover na direção de uma sociedade capaz de se desenvolver a partir da redução destes níveis, simultaneamente melhorando a qualidade de todo o ambiente social e físico. (MANZINI, 2008. p.19)

A descontinuidade sistêmica compreende a transformação do ritmo acelerado e, muitas vezes, insensato que a indústria impõe à sociedade contemporânea. Manzini (2008. p. 19) afirma que esta descontinuidade irá ocorrer e que tal transformação será mediante um processo de aprendizagem social amplamente propagado. Do mesmo modo, assegura que a descontinuidade irá atingir todas as dimensões inseridas no sistema sociotécnico: física, econômica, industrial, ética, estética e cultural.

Estas dimensões interagem entre si sob a influência do tempo e do espaço. O tempo está relacionado com a amplitude do período (curto ou longo) 
em que a descontinuidade é realizada. Quanto ao espaço, significa que a descontinuidade pode ocorrer em macroescala (global) ou microescala (local).

As dimensões físicas, segundo Manzini (2008. p. 19), compreendem os fluxos de materiais energéticos, ao passo que a dimensão econômica está relacionada com os atores sociais envolvidos. Por fim, as dimensões ética, estética e cultural abrangem os valores e juízos de qualidade.

O sistema sociotécnico definido por Manzini (2008. p. 19) pode ser balizado por termos que são comuns nos discursos do cotidiano. Por exemplo, a dimensão física, que abrange o conjunto dos recursos naturais, é mencionada como ambiental, ao passo que a dimensão que envolve a relação entre o setor financeiro e as pessoas envolvidas é tratada como dimensão econômica. Por fim, a dimensão que está relacionada com os valores e juízos da sociedade é denominada social.

Neste sentido, o sistema sociotécnico pode direcionar as dimensões para os seguintes aspectos: do meio ambiente, da economia e do social, permanecendo a influência do tempo e do espaço.

Podemos perceber um diálogo entre Viana e Manzini, quando ambos comentam a respeito das implicações dos modelos econômicos nas comunidades. O que distingue os autores, contudo, é a constituição destas comunidades. Enquanto Viana se concentra nas comunidades afastadas, comunidades da floresta, destituídas de elaborados processos fabris; Manzini preza a reformulação dos modelos de produção que afetam as comunidades consumidoras, as comunidades urbanas e industrializadas.

Margolin (2014. p. 121) sinaliza, por sua vez, a influência da cultura de consumo na atividade projetiva do design, considerando que a profissão é responsável pela configuração de produtos voltados para a indústria, pelo menos foi isso que aconteceu durante o período da Revolução Industrial. Esta definição vem sofrendo transformações. Hoje, o design enfrenta mudanças de conteúdo agregando outras atividades e admitindo novos significados. Estas mudanças dão origem a novos segmentos e especialidades na atuação profissional do designer para além da configuração de produtos.

Por muito tempo, o design esteve comprometido em expandir o mercado e a economia global, sendo um aporte para fortalecer a concorrência entre os produtos, tudo isto seguindo os padrões do modelo expansionista econômico vigente. Este modelo vem sendo criticado pelas atitudes utilizadas para alcançar esta expansão, para alcançar este desenvolvimento econômico. Existem regras e valores que são impostos a todo custo, negligenciando as consequências 
maléficas para o tecido social e para o meio ambiente. Por mais arbitrário que o modelo expansionista seja, ele permanece vigorando e perpetuando um sistema dominante onde a protagonista é a cultura do consumo.

Para Margolin (2014. p. 126) "...os designers não têm conseguido imaginar uma prática profissional fora da cultura de consumo dominante." $\mathrm{O}$ autor admite que os designers estão subjugados à demanda empresarial e que têm demonstrado pouca autonomia no sentido de realizar projetos para beneficiar comunidades de baixa renda. Neste sentido, ocorre uma reação mais dialética do que uma reação proativa. Existem poucos projetos significativos direcionados para a perspectiva social.

Margolin (2014. p. 126) aponta ainda dois nomes que estiveram preocupados com o design voltado para as questões sociais, a saber, $R$. Buckminster Fuller e Victor Papanek.

Papanek, apud Margolin (2014. P.123), anunciou que o design colaborava para a deterioração do meio ambiente, inserindo com esse seu pronunciamento um novo elemento no discurso do design. A questão é reiterada no livro Design for the Real World, de Papanek:

Hoje, o desenho industrial colocou o assassinato em uma produção de massa. Ao
projetar automóveis criminosamente inseguros que matam e aleijam quase um
milhão de pessoas por ano no mundo inteiro, ao criar novas espécies inteiras de
lixo que se amontoam na paisagem e ao escolher materiais e processos que
poluem o ar que respiramos, os designers se tornam uma raça perigosa.
(PAPANEK, 1972).

Este novo elemento no discurso do design que Papanek menciona representa a dicotomia da profissão, em que o designer busca resolver as necessidades do homem através do desenvolvimento de produtos ou processos e não contabiliza suas implicações.

Quando foi criado o automóvel, foi solucionada a mobilidade das pessoas, entretanto, foram negligenciados os acidentes automobilísticos que provocam sequelas e até mortes para o usuário. Verifica-se ainda que outros objetos seguem o exemplo do automóvel, ou seja, equalizam um problema e geram outros problemas maiores e fatais. Neste sentido, o design se tornou um instrumento de destruição, de enfermidade, de morte e de poluição ambiental.

Devido ao compromisso, quase inseparável, que o design tem com a produção fabril e com todo o sistema dominante da cultura de consumo, está difícil enxergar que é possível exercer a profissão sem vínculos danosos com o sistema dominante. 
O design continua tendo uma preocupação extrema com a produção fabril para atender a um maior número de pessoas, assim como uma parceria com o sistema dominante que enaltece a cultura do consumo. Mas Margolin (2014. p. 136) diz ser possível encontrar alternativas que atentem para os aspectos sociais e os aspectos ambientais. Ele exemplifica uma prática que foge dos padrões do sistema dominante, realizada pelo Dr. Luiz Eduardo Cid Guimarães, na Paraíba, que busca melhorias nos bens produzidos por microempresas destinados para populações desprovidas de recursos financeiros.

Outros teóricos do design, segundo Margolin (2014. P.125), reforçaram o pensamento de Papanek, a saber, Tomás Maldonaldo e Gui Bonsiepe. Questões sobre a sustentabilidade foram discutidas com mais frequência no ambiente do design, a partir da década de 70 , e, desde então, foi surgindo uma cultura sustentável para se contrapor à cultura do consumo.

As mudanças de conteúdo no design, assim como a inserção de novos segmentos, a superação do sistema dominante e a cultura da sustentabilidade são vetores que estão impulsionando o design a ordenar uma nova estrutura organizacional para se estabelecer nesta conjuntura atual. O mais apropriado para construir esta estrutura está sendo sinalizado em direção aos princípios do desenvolvimento sustentável.

Esta conjuntura que começa a se delinear é a sociedade "pós-produto", como é cunhada por alguns críticos e teóricos. Conforme Clive Dilnot:

O movimento rumo a uma sociedade "pós-produto", ou seja, a uma sociedade caracterizada por uma gestão social mais explícita das relações entre o homem e o meio ambiente, provavelmente trará este sentido histórico da importância do design (como planejamento). O design mais uma vez se torna antes um meio de ordenar o mundo do que meramente de configurar mercadorias. (DILNOT apud MARGOLIN 2014. p. 127)

Nesta sociedade pós-produto, o design deve ir além da configuração morfológica dos produtos, como também deve superar as intervenções pontuais de produtos com o paradigma sustentável. Margolin (2014. p. 133) alerta para uma abordagem sistêmica com alcance maior do que apenas um produto. $O$ design deve se estender para o desenvolvimento de produto e processos acatando um planejamento de grande amplitude social e ambiental. Neste sentido, o autor aponta os seis temas tratados no relatório da Cúpula da Terra: qualidade de vida; uso eficiente de recursos naturais; proteção para áreas comuns globais; gestão de assentamentos humanos; uso de produtos químicos e manejo do lixo humano e industrial; e fomento econômico sustentável em uma escala global. Cada tema abrange uma extensa atuação, para a qual o design tradicional tem dado uma pequena contribuição. 
Portanto, a partir dos itens citados no relatório da Cúpula da Terra, Margolin recomenda alguns itens passíveis para intervenções do design que são: a reciclagem de produtos; sistema de transporte seguro e acessível; mudanças nos modelos de consumo; uso consciente dos produtos florestais; redução das embalagens nos produtos; expansão do ecoturismo e do turismo cultural; e colaboração aos povos para autonomia econômica, como por exemplo no caso dos povos indígenas.

Além da relevância do sistema sociotécnico, articulado por Manzini, e as discussões de outros autores, trazidas neste capítulo, podemos também incluir neste arcabouço teórico o Design Orientado ao Meio Ambiente (Design for Environment - DE), e a Análise do Ciclo de Vida - ACV (Life-Cycle Assessment $L C A$ ), que estão relacionados ao conceito de sustentabilidade, e serão apresentados a seguir.

\subsection{1}

\section{Design Orientado ao Meio Ambiente (DfE - Design for Environment)}

O Design Orientado ao Meio Ambiente (DfE - Design for Environment) é uma metodologia frequentemente adotada nas áreas do design, da arquitetura e da engenharia.

O Design Orientado ao Meio Ambiente (DfE - Design for Environment), de acordo com Rose (2000. p. 27), analisa os aspectos ambientais em cada etapa do processo de desenvolvimento do produto. Neste processo, é dado ao meio ambiente o mesmo status que se dá aos requisitos projetuais tradicionais, como funcionalidade, estética, ergonomia e processo fabril. O DfE trata do desenvolvimento de produtos e processos, amparado por um conjunto de técnicas, com base em conceitos relacionados à saúde humana, à segurança $e$ ao meio ambiente. Neste sentido, o DfE abrange outras disciplinas afins que buscam minimizar impactos ambientais, considerando o desenvolvimento de produtos e processos desde o seu estágio inicial até a sua finalização para uma reutilização. Tais disciplinas são: Design Orientado à Montagem (DfA - Design for Assembly), Design Orientado ao Serviço (DfS - Design for Service), Design Orientado à Reciclagem (DfR - Design for Recyclability) e Design Orientado à Desmontagem (DfD - Design for Disassembly).

O Design Orientado à Montagem (DfA - Design for Assembly) valoriza os aspectos econômicos do projeto que, por sua vez, estão relacionados com a 
quantidade de componentes e simplificação do processo de instalação. No processo fabril, a quantidade de peças possui uma relação direta com o tempo de montagem, e isso significa que o menor número de peças resulta em menor tempo na fabricação, o que produz economia e ganho maior no custo final do produto. Além disso, se os componentes possuem características simplificadas, torna-se mais fácil mover, inserir, retirar, entre outras atividades que merecem ajustes das peças. Neste sentido, o DfA aprecia os aspectos relacionados à simetria, ao tamanho, ao peso, à espessura e à flexibilidade, assim como aos encaixes entre componentes.

O Design Orientado ao Serviço (DfS - Design for Service) pretende reduzir a troca do produto, a partir de um trabalho de manutenção durante a sua vida útil, ao passo que o Design Orientado à Reciclagem (DfD - Design for Recyclability) busca materiais que tornem possível a reciclagem por meio da transformação com menor impacto ambiental.

Por último, o Design Orientado à Desmontagem (DfD - Design for Disassembly) viabiliza produtos que possam ser reutilizados. De acordo com Oliveira (2000. p. 73), a desmontagem corresponde à manutenção, à remanufatura, à reciclagem de materiais, à reutilização, à redução do descarte e à recuperação da energia. A desmontagem apresenta vantagens, sobremaneira, a viabilidade econômica.

Em resumo, o Design Orientado ao Meio Ambiente é um modelo projetual norteado por diretrizes ecológicas que fazem parte dos princípios da sustentabilidade, principalmente quanto à economia do emprego dos materiais, o que significa aquisição e uso dos recursos naturais com cautela e prudência. Neste sentido, temos a metodologia da Análise do Ciclo de Vida (ACV) que será comentada no próximo subitem. 


\subsection{2}

\section{Análise do Ciclo de Vida - ACV (Life-Cycle Assessment - LCA)}

A Associação Brasileira de Ciclo de Vida - ABCV (2003) estabelece que o termo Life-Cycle Assessment pode ser utilizado também, em versão traduzida, como Avaliação do Ciclo de Vida em vez de Análise do Ciclo de Vida. Isso porque o emprego da palavra análise se mostra insuficiente para descrever a abrangência da ACV e as atividades do método. Na prática, o método consiste em reunir as informações de um sistema de produto e depois analisar os dados para, em seguida, interpretá-los e avaliá-los. Contudo, os grupos de pesquisa do Brasil adotaram a expressão Análise do Ciclo de Vida.

Segundo a International Standardization for Organization (ISO), a norma 14040 denominada Análise do Ciclo de Vida é definida pela "compilação e avaliação de entradas e saídas (de matérias-primas e recursos energéticos) e impactos ambientais potenciais de um produto através de seu ciclo de vida".

A Análise do Ciclo de Vida - ACV (Life-Cycle Assessment - LCA) tem sido aplicada nos setores de desenvolvimento de produtos e processos, com o objetivo de identificar o consumo excessivo de energia e de materiais e buscar alternativas para reduzir os impactos ambientais. Nesta pesquisa, será adotada a sigla ACV sempre que tratarmos da Análise do Ciclo de Vida.

O método envolve um conceito holístico, uma análise geral do processo industrial, entretanto pormenorizado em suas fases. Com o emprego do ACV, é possível revelar as restrições industriais e os limites dos recursos naturais e consumo de energia, assim como observar o destino dos resíduos nas etapas correlatas. Tal método corresponde ao levantamento detalhado de todas as etapas de um ciclo, seja de produto, seja de serviço, verificadas do berço ao túmulo (cradle-to-grave) (ISO, 2002).

A aplicação deste método ACV nas etapas de um processo fabril é fortemente recomendável. Em cada atividade industrial ocorre um consumo energético que, por sua vez, libera, para o meio ambiente, gás carbônico, resíduos sólidos, gasosos e líquidos, dentre outros elementos poluentes. A ACV traz benefícios, portanto, quando se trata da produção de bens e serviços que geram impactos ambientais.

Uma grande vantagem da ACV, de acordo com Heiskanen (2002), refere-se à possibilidade de se detectar os impactos ambientais no processo produtivo, e se revelar a etapa afetada, as causas e as consequências destes impactos. Em outras palavras, podemos dizer que o método auxilia a se investigar, 
pontualmente, todas as ações envolvidas em um determinado processo em relação ao consumo de matéria-prima e de energia. Do mesmo modo, pode-se constatar a formação de resíduos nas etapas do processo fabril, assim como na fase de uso, seja de um produto, seja de um serviço. Heiskanen (2002) ainda exemplifica e destaca a ocorrência de processos fabris que conseguem produzir com recursos naturais e energéticos reduzidos, entretanto, ressalta que o mesmo não ocorre em relação ao uso de um produto, como também ao seu descarte. Neste sentido, a ACV propõe um acompanhamento desde a concepção do produto até o seu descarte, prospectando, inclusive, a sua reutilização.

Outra vantagem ao se adotar a ACV é o estabelecimento de uma política econômica com padrões definidos, em que seja possível um gerenciamento ambiental congruente entre governos (European Environment Agency - EEA, 1997. p. 44).

Para diminuir o impacto ambiental, atualmente o mais sensato a se fazer vem sendo a busca por modelos produtivos e de consumo sustentáveis, que envolvem diversos atores sociais. O método ACV reúne padrões sistêmicos que consistem nas seguintes etapas: pré-produção, produção, distribuição, uso, descarte e reciclagem e/ou reutilização (Figura 1).

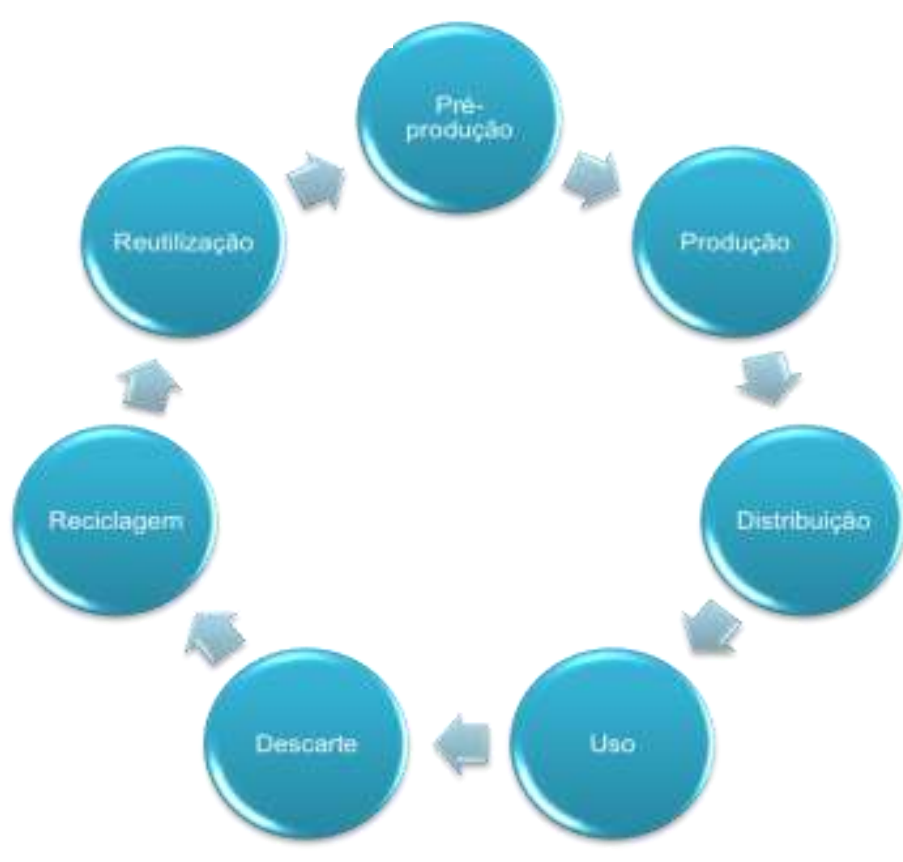

Figura 1 - Análise do Ciclo de Vida - ACV (Life-Cycle Assessment - LCA).

Todavia, para aplicar o método ACV como ferramenta em um modelo conceitual para a produção do açaí não basta apenas seguir as orientações como regras absolutas, são necessárias algumas adaptações básicas, como por 
exemplo, mudanças nos hábitos da sociedade industrial, educação ambiental, revisão da seleção e da inserção de materiais no sistema produtivo e eleição de processos de desenvolvimento de produtos de baixo impacto. Em resumo, a sociedade deve adotar uma postura consciente tanto em nível de produção, quanto em nível de consumo. Todas as etapas da cadeia produtiva devem ser enfáticas nas ações mitigadoras.

O método ACV consta de sete etapas. A primeira denominada de préprodução compreende a extração dos recursos naturais. Na fase seguinte, ocorre a produção que transforma os recursos naturais em matéria-prima e produtos. $A$ terceira fase é destinada à distribuição dos produtos para os centros consumidores. A quarta fase compreende o consumo do produto. A quinta fase denominada de descarte trata do produto pós-consumo. A próxima fase envolve a reciclagem, que consiste no aproveitamento do produto por meio do processo fabril. A sétima e última fase é a reutilização, a qual evita o processo industrial e incorpora uma logística de reutilização do produto de modo simplificado.

A descrição das etapas da ACV é apresentada aqui de modo genérico. Entretanto, para cada produto, deverão ser observadas e respeitadas as respectivas particularidades que são intrínsecas aos diversos processos industriais.

Nesta pesquisa, a ferramenta do método de Análise do Ciclo de Vida foi utilizada como exemplo para a compreensão da dinâmica das etapas da cadeia produtiva do açaí para visualizar a sequencialidade destas etapas e verificar os possíveis entraves existentes.

\section{2}

\section{Delimitação conceitual entre ecodesign, design social, design} participativo, design sustentável e tecnologia apropriada

Nesta seção, discorreremos sobre a delimitação conceitual das metodologias sustentáveis emergentes, a fim de, posteriormente, estabelecer uma articulação e discussão desses conceitos na elaboração de uma proposta de modelo conceitual para a produção do açaí.

Segundo Sachs (2009. p. 71), como já dito anteriormente, o termo sustentabilidade apresenta outras dimensões, além da dimensão ambiental, uma vez que abrange, também, a responsabilidade social, cultural, territorial, 
econômica e as políticas públicas. A partir da ênfase nestas dimensões, consolidam-se novas metodologias. No ambiente do design, podemos citar algumas metodologias que envolvem estas dimensões, e, por isso, consideramos metodologias sustentáveis emergentes, como por exemplo, o ecodesign, o design social, o design participativo, o design sustentável e a tecnologia apropriada.

\subsection{1}

\section{Ecodesign}

Segundo Oliveira (2000. p. 51), as alterações ambientais implicaram mudanças conceituais no design e também proporcionaram variações na terminologia, haja vista os termos "Design para as necessidades" e "Design alternativo", ocorridos nos anos 70; e "Ecodesign", "Design verde" ou "Design ambiental" nos anos 90 .

O conceito de ecodesign surge na década de 90 com ênfase nos processos de fabricação. No ano de 2004, segundo Queiroz (2014. p. 50), o Comitê Brasileiro de Gestão Ambiental lançou um Relatório Técnico ISO/TR 14062 referente ao desenvolvimento do produto integrado com os aspectos ambientais. Tal relatório tem como objetivo "maximizar inovações e oportunidades para a melhoria ambiental".

O ecodesign tem como prioridade minimizar os impactos ambientais ocorridos no processo de fabricação, contemplando os seguintes critérios: a durabilidade do produto, a reciclagem, o reaproveitamento das partes do produto e o menor consumo energético tanto na produção quanto no uso.

Esta metodologia remete à ecoeficiência que, por sua vez, propõe a redução da extração dos recursos naturais, o aumento da produtividade com melhor qualidade e menor formação residual. Neste contexto, surge a tecnologia limpa que reúne estratégias para utilizar os recursos naturais com o objetivo de reduzir o desperdício. 


\section{2 .2}

\section{Design social}

O design social visa atender às necessidades de grupos menos favorecidos econômica, cultural e socialmente, assim como a portadores de necessidades especiais devido à idade, à saúde e à incapacidade.

Conforme Margolin (2004. p. 3), o que define o objetivo principal do design social é a satisfação das necessidades humanas. Para alcançar este objetivo, o design adota a psicologia ambiental que empreende uma abordagem interdisciplinar para implementar soluções. Neste contexto, segundo Margolin (2004. p. 2), são envolvidos vários profissionais com a finalidade de se identificar as necessidades das pessoas pela avaliação das relações que se estabelecem entre elas e o ambiente em que se encontram.

Para desenvolver um "modelo social" nós iremos usar como recurso a literatura de assistência social, uma prática cujo objetivo principal é o de suprir as necessidades das populações injustiçadas ou marginalizadas. No centro da teoria da assistência social está a perspectiva ecológica. Os assistentes sociais avaliam a transação que ocorre entre o sistema de seus clientes (uma pessoa, família, grupo, organização ou comunidade) e os domínios dentro do ambiente com o qual o sistema de clientes interage. Os vários domínios que têm um impacto sobre o funcionamento humano são o biológico, psicológico, cultural, social, natural e físico/espacial. (MARGOLIN, 2004. p. 3).

Margolin (2004. p. 4) apresenta a metodologia empregada pelos assistentes sociais como uma prática a ser utilizada no design social. A técnica se estrutura em seis etapas: compromisso, avaliação, planejamento, implementação, estimativa e finalização. A primeira etapa compreende ouvir o sistema do cliente (pessoa, família ou comunidade) e conhecer minuciosamente o problema. A próxima etapa, de modo holístico, observa a interação das pessoas envolvidas e os domínios ambientais, esta etapa tem como objetivo definir a origem dos problemas com uma lista das necessidades a serem atendidas. $\mathrm{Na}$ fase do planejamento é determinante priorizar as necessidades e conjuntamente encontrar soluções para estas necessidades. Em seguida, traçar as metas e objetivos com um cronograma de atividades. As duas etapas seguintes monitoram o que foi programado na etapa anterior.

Conforme Couto apud Carvalho (2012. p. 55), o design social prioriza a participação do usuário nas etapas de desenvolvimento do projeto, comportandose de maneira antagônica ao sistema convencional de projetar, que valoriza a produção em série e está comprometido com a indústria. 


\subsection{3}

\section{Design Participativo}

No design participativo, o cerne da questão incide em mobilizar o públicoalvo para participar da elaboração da problematização projetual, fornecendo informações, e também para encontrar as possíveis soluções.

O design participativo vem ganhando espaço no campo do design, e esta assertiva é confirmada no artigo O Tempo do Design Participativo:

Nos últimos anos numerosos estudos têm apontado para potencialidades de processos co-criativos e participativos de Design que pretendem contribuir na resolução de questões sociais e na melhoria do contexto de vida cotidiano da população envolvida, quando aplicados no âmbito social. (GAUDIO et al., 2014. p. 2)

Neste contexto, são valorizados o conhecimento técnico e as experiências da população. Para tal, é fundamental ouvir as reais necessidades do públicoalvo, detectadas nas falas e nos eventos, muitas vezes de modo não explícito. É importante decodificar em seus discursos essas necessidades físicas, psicológicas, econômicas, sociais e culturais, para dar prosseguimento ao projeto.

Entender e captar essas necessidades do público-alvo não é tão simples quanto parece. As necessidades e os desejos permeiam o universo subjetivo. $O$ designer vislumbra um entendimento objetivo a respeito do que sejam as necessidades do público. No entanto, esta compreensão não surge com frequência no cotidiano da profissão. A necessidade e o desejo são anunciados de maneiras similares, porém com particularidades divergentes. Como exemplo, pode ser mencionado o desejo de um mundo melhor, que é um desejo quase unânime, porém que é proclamado de formas diferentes.

\subsection{4}

\section{Design sustentável}

Pazmino (2007. p. 7 e 8) diz que o design sustentável é abrangente e complexo. Em sua compreensão, o design sustentável abrange os objetivos ambientais, econômicos e o aumento do bem-estar social, propondo a responsabilidade de não prejudicar o equilíbrio ambiental atual e garantir este equilíbrio para as gerações futuras. 
A crise ambiental que estamos vivendo no momento atual leva o design a assumir uma postura em que os princípios da sustentabilidade façam parte intrinsecamente do seu conjunto de estratégias.

A ideia de bem-estar é uma construção social que se forma ao longo do tempo, de acordo com uma variedade de fatores. A ideia de bem-estar hoje dominante no ocidente e amplamente difundida por todo o mundo nasceu com a revolução industrial. (Manzini, 2008. p. 39)

A partir do discurso de Manzini, pode ser observado que existe uma relação entre a ideia de bem-estar e a indústria. O sistema industrial relaciona a concepção de bem-estar com a condição de ter produtos industrializados. Este modelo industrial motivado pelo aumento da produtividade gera um mecanismo que fortalece o consumo.

O consumo fortalece a indústria, por outro lado, fragiliza o meio ambiente. O fortalecimento industrial empreende a extração excessiva dos recursos naturais e não relativiza a possibilidade de finitude destes recursos. É insensato admitir o consumo como a única alternativa para o bem-estar e desprezar seus impactos ao meio ambiente.

Neste sentido, a ideia de bem-estar, definida como uma resultante da posse de objetos, necessita ser reavaliada para discutir as adversidades do consumo e suas implicações, para que desse modo seja possível configurar outras possibilidades. O design sustentável propõe novos modelos de consumo e de produção que apontam outros caminhos ultrapassando a fronteira do consumo e apreciando o compartilhamento de objetos. Estes novos modelos exigem do sistema industrial um novo direcionamento, que requer um processo educacional. Como é sabido, o sistema industrial possui uma estrutura complexa e fortalecida por diversos atores sociais que irão reagir antagonicamente com a implementação dos novos modelos de consumo e de produção. Esta empreitada apresenta indícios de uma atividade laboriosa, mas que não é impossível.

\section{2 .5}

\section{Tecnologia Apropriada}

A tecnologia apropriada (TA) envolve ferramentas e processos simplificados para solucionar problemas complexos. Busca reduzir as dificuldades relacionadas à pobreza e suas consequências, como por exemplo a escassez de alimentos, a falta de assistência médica, a educação precária, a insuficiência de água potável e a ausência de moradia. TA é denominada, também, como 
tecnologia de baixo custo e tecnologia intermediária. Esta tecnologia surge em resposta ao desenvolvimento socioeconômico atrelado às questões ambientais. É uma prática bastante empregada nos países em desenvolvimento nas décadas de 70 e 80, mas nas últimas décadas, os países desenvolvidos vêm aderindo também à tecnologia apropriada, ou seja, vêm adotando a tecnologia limpa para conseguir diminuir o uso de materiais e reduzir o consumo energético.

Parafraseando Dhal e Pattnaik (1977. p. 4), a tecnologia apropriada ressalta o valor endógeno e autossuficiente devido à participação social, o que significa que é necessário o envolvimento da comunidade para resolver seus próprios problemas: criar soluções e viabilizar as melhorias. É a comunidade que detecta o problema, encontra a solução, desenvolve a tecnologia e viabiliza sua operacionalidade. Este modus operandi recomenda a originalidade e evita cópias de modelos externos fundamentados em realidades diferentes. Além do valor genuíno, ocorrem também a independência e a autonomia tecnológica. Este feito colabora para a formação de uma comunidade que pensa e determina suas ações econômicas, sociais, culturais e ambientais. São ações que promovem conquistas para o empoderamento político da comunidade. A tecnologia apropriada busca a redução do emprego de materiais, prudência para a extração de recursos naturais, a reutilização de materiais e objetos, o reaproveitamento de peças, a facilidade de execução e uso dos objetos, a segurança do ser humano, por fim, prioriza o ser humano e o seu entorno. Os benefícios da TA abrangem a diminuição dos impactos ambientais, a geração de emprego e evita a tecnologia importada.

A questão da eficiência energética é observada na TA, e do mesmo modo, ocorre um grande apreço para manter as tradições da comunidade e pela valorização cultural, Diante dos indicadores apresentados, a TA colabora para o delineamento de estratégias sustentáveis que conjugam o desenvolvimento econômico com os limites do meio ambiente.

A tecnologia apropriada é absorvida também no meio rural, e aplicada em pequenas unidades de produção, de acordo com Guimarães e Dantas (2008. p. 7), com o propósito de atender às necessidades da comunidade em respeito aos seus costumes e à questão financeira. Todavia, as dificuldades para a aplicabilidade da TA são encabeçadas pela dificuldade de se obter informações mercadológicas, dificuldade essa que impede o pequeno produtor de expandir seu mercado, somada ao isolamento geográfico em que se encontram as comunidades rurais. Em resumo, Guimarães e Dantas (2008. p. 11) alegam que 
os projetos realizados com a TA promovem pequenas intervenções na comunidade e fornecem elementos para a construção de políticas. Tais intervenções não são absolutas, no sentido de resolver todos os problemas da comunidade, mas podem minimizar as adversidades dessa população.

Minimizar as adversidades da comunidade, na minha opinião, já representa uma grande vantagem, não importa se as intervenções são decisões definitivas, não importa a quantidade nem o tamanho das intervenções. $O$ importante é estar em contínua busca de melhorias para a comunidade em respeito às suas limitações. Considero uma outra prerrogativa da TA a possibilidade da própria comunidade tornar-se detentora dos seus problemas, e ter o controle sobre eles. Ou seja, a comunidade desenvolve uma capacidade de autonomia socioeconômica conquistada por meio da tomada de consciência.

Por outro lado, é certo que tomar consciência demanda tempo e as questões sociais, econômicas e ambientais, na maioria das vezes, não são reveladas com a finalização do projeto, também necessita de tempo para as vantagens da TA serem identificadas. Neste sentido, o emprego da TA não apresenta respostas imediatas em contextos que requer soluções urgentes, por este motivo suas vantagens são negligenciadas.

Para a aplicabilidade da tecnologia apropriada, é necessário priorizar as questões sociais, econômicas e ambientais. A responsabilidade ambiental, conforme Guimarães e Dantas (2008. p. 11 e 12), se estende não só ao poder público, mas também, a ONGs, associações e escolas primárias e secundárias. Do mesmo modo, aos cursos superiores de Design, que devem incluir em seus projetos pedagógicos temas relacionados à interseção entre a economia e o meio ambiente.

O emprego da TA nos países em desenvolvimento perpassa pelo design, sendo questionado o seu papel. Neste sentido, a atuação do design nos países em desenvolvimento é inexpressiva. O design dedicou pouca atenção para as necessidades da população de baixa renda. Segundo Bonsiepe (1990 apud GUIMARÃES e DANTAS, 2008. p. 2), somente em 1973 foi discutido pela Organização das Nações Unidas (ONU) o documento Development Through Design, escrito por Bonsiepe e encaminhado pelo Conselho Internacional das Sociedades de Design Industrial - (ICSID). Este feito tornou-se um marco histórico para a formação da política do design. A discussão teve como foco a industrialização direcionada para o crescimento econômico dos países em desenvolvimento. 
Desde então, alguns projetos foram realizados para minimizar os problemas sociais. Todavia, esta colaboração do design foi insuficiente e de pouca representatividade no que tange a demanda social. Foi comentado por Bonsiepe (1979. p 45-50) que ocorria uma dedicação secundária aos projetos sociais e estes não estavam na lista de prioridades do design. Guimarães e Dantas (2008. p. 2) expressam a mesma opinião e afirmam que o design tem direcionado pouca atenção para as necessidades da população marginalizada nos países em desenvolvimento.

Ainda segundo Guimarães e Dantas (2008. p. 4 e 5), algumas entidades estão envolvidas com o desenvolvimento de produtos e serviços de âmbito social, e merecem ser mencionadas: Alternative Product Working Group na Alemanha; Unit for the Development of Alternative Products em Coventry; Sheffield Centre for Products Development and Technological Resources; Institute of Design na Índia; Pontifícia Universidade Católica do Rio de Janeiro - PUC - RJ no Brasil e o Industrial Design and Sustainable Development Group - GDDS da Universidade Federal de Campina Grande - UFCG.

A tecnologia apropriada é associada a uma alternativa de baixo custo, com redução de materiais e emprego de tecnologia acessível, raeplicada em comunidades desfavorecidas financeiramente. Contudo, existe um desvio da função da tecnologia apropriada, que muitas vezes é realizada sem planejamento, conduzida na base do improviso, reduzida a um arranjo projetual mal feito com sobras de materiais. Este desvio está atrelado à crença de que projetos direcionados para os desfavorecidos podem ser elaborados de qualquer maneira e não existe rigor na qualidade do serviço, e tampouco sendo solicitada eficiência no projeto.

Tanto a tecnologia apropriada quanto as metodologias emergentes são soluções indicadas e adequadas para serem adotadas pelos países em desenvolvimento, e portanto, no nosso caso, recomendadas para o desenvolvimento de uma proposta de modelo conceitual para a produção do açaí.

A discussão da sustentabilidade, na atualidade, está sendo edificada com novas situações que colocam em pauta temas que não são tão novos, mas que predominam na plataforma do desenvolvimento sustentável. Tais temas abrangem a escassez dos recursos naturais, a fragilidade do sistema social, as políticas públicas inoperantes e a desigualdade econômica. Esta plataforma está gerenciando as metodologias sustentáveis emergentes, e pode ser observada no ambiente do design nas últimas duas décadas com maior ênfase. 
As metodologias sustentáveis emergentes e a TA representam novas frentes de trabalho, novos segmentos ou novos campos de atuação, que conduzem a uma ampliação profissional e apontam para uma reflexão crítica nos postulados metodológicos da profissão. Para enriquecer a discussão a respeito destas diretrizes metodológicas, uma possibilidade é trazer o tema da doutrina humanista.

O humanismo trata do saber crítico racionalista, em que o cerne é a ética. Propõe uma nação igualitária, embora nesta uniformidade estejam incluídas as diferenças de crenças, de etnias, de línguas, de costumes e de culturas. Sua filosofia promulga o mundo sem dirigentes, neste sentido, corrobora a fala de Bonsiepe (2011. p. 21) que diz:

O humanismo projetual seria o exercício das capacidades projetuais para interpretar as necessidades de grupos sociais e elaborar propostas viáveis, emancipatórias, em forma de artefatos instrumentais e artefatos semióticos. (BONSIEPE, 2011. p. 21)

Abordar o design com o viés do humanismo favorece a reavaliação dos requisitos e a metodologia adquiridos e reproduzidos pelo design dominante. Elaborar propostas emancipatórias condiz com 0 empoderamento dos participantes dos grupos sociais por meio da intervenção do design. A intenção é que esta avaliação dos domínios seja balizada nos preceitos da sustentabilidade e configure uma plataforma para um design mais humano, flexível e abrangente.

Com base no desenvolvimento da delimitação conceitual entre ecodesign, design social, design participativo e design sustentável apresentada, foram compiladas características que representam tais metodologias e elaborada uma síntese, como mostra a Tabela 1 abaixo.

\begin{tabular}{|l|l|}
\hline Ecodesign & $\begin{array}{l}\text { Minimizar os impactos ambientais ocorridos no } \\
\text { processo de fabricação. }\end{array}$ \\
\hline Design Social & $\begin{array}{l}\text { Atender a grupos menos favorecidos e portadores de } \\
\text { necessidades especiais. }\end{array}$ \\
\hline Design Participativo & Desenvolver projetos de forma colaborativa \\
\hline Design para sustentabilidade & $\begin{array}{l}\text { Desenvolver novos modelos de consumo e de } \\
\text { produção. }\end{array}$ \\
\hline Tecnologia apropriada & $\begin{array}{l}\text { Solucionar problemas complexos com ferramentas e } \\
\text { processos simplificados }\end{array}$ \\
\hline
\end{tabular}

Tabela 1 - Características das metodologias emergentes sustentáveis. 
A intenção desta Tabela é mostrar sinteticamente o que identifica cada metodologia e nortear a elaboração de critérios projetuais para o desenvolvimento de uma proposta de modelo conceitual para a produção do açaí que será tratado no Capítulo 5.

O esforço em delimitar conceitualmente estes termos é válido para dinamizar a retórica sustentável do design. Esta discussão contribui para instrumentalizar os fundamentos metodológicos do design e consolidar estes novos segmentos para o confronto dialético e também mercadológico.

Nesta pesquisa reunimos as metodologias emergentes e a tecnologia apropriada para abordar a interface do design com a sustentabilidade. Cada metodologia possui uma característica que é revelada de acordo com o direcionamento que é dado no processo projetual, por exemplo, o ecodesign prioriza ações mitigadoras para os impactos ambientais ocorridos durante o processo de fabricação; ao passo que, o design social estabelece como princípio o desenvolvimento de produtos para grupos menos favorecidos e portadores de necessidades especiais; já o design participativo valoriza a participação dos envolvidos no projeto; o design sustentável, o emprego de novos modelos de consumo e de produção e, por fim, a tecnologia apropriada emprega ferramentas e processos simplificados para solucionar problemas complexos.

O valor destas metodologias consiste nas ênfases que adotam no processo projetual, assim como na viabilidade dos aspectos técnicos e aspectos humanos (sociais, culturais e políticos) envolvidos no processo. Os teóricos que abordam tais metodologias, como por exemplo, Bonsiepe, Papanek, Manzini e Margolin assinalam como eficiência do resultado projetual a reunião dos aspectos técnicos e dos aspectos humanos no mesmo grau de relevância.

Neste sentido, verifica-se que as metodologias estão fundamentadas com base em informações de áreas distintas, e conjugar informações de campos de conhecimento diferentes é um procedimento difícil. Isso torna o processo projetual complexo, em virtude de ter que compatibilizar conhecimentos diferentes. Por outro lado, toda esta complexidade torna o resultado do projeto eficiente tecnicamente e com característica mais humana. Esta habilidade que poucas profissões dominam, ou seja, conciliar os aspectos técnicos com os aspectos humanos, o design exerce com maior fluidez.

Outro ponto importante, considerado nas metodologias emergentes e principalmente na tecnologia apropriada, é a maneira endógena de observar o problema, de avaliar pontualmente os elementos que são responsáveis pelo 
problema, e de encontrar soluções na própria comunidade.. Ponderar o entorno, resgatar suas potencialidades e compreender suas fragilidades. Os elementos a serem observados devem se concentrar nos recursos disponíveis; no envolvimento das pessoas; no emprego da mão-de-obra local; no uso dos materiais acessíveis, na valorização da cultura local; enfim, na apreciação da comunidade como a geradora de soluções para seus problemas.

Desta forma, proponho o emprego das metodologias emergentes, assim como a apreciação da tecnologia apropriada, como práticas que se tornem uma rotina profissional e didática. $O$ design fundamentado na sustentabilidade revela sua importância na atividade projetual, tanto como ferramenta metodológica, quanto como instrumento educacional, colaborando para a reestruturação de um sistema de consumo e de um modelo de produção mais adequados à realidade, revendo as arestas do design para que a interface com a sustentabilidade seja fluente.

A discussão apresentada neste capítulo nos mostra como, ao longo de sua história, o design foi se transformando, até chegar à visão e entendimento da necessidade de conexão do design com as ciências sociais para enfrentar os desafios deste século. No próximo capítulo, a geopolítica do Amazonas e modelos sustentáveis realizados no estado são apresentados, como uma referência, inspiração para o desenvolvimento de um modelo conceitual para a produção do açaí para a região. 
3.

\section{As questões geopolíticas da Amazônia na elaboração de uma proposta de intervenção sustentável do design}

Com a finalidade de propor um modelo conceitual para a produção do açaí para a região do Amazonas, é necessário entender as dificuldades que existem no estado. Estas questões estão inseridas na pauta geopolítica da Amazônia. O estado compreende uma grande extensão territorial com peculiaridades singulares na formação urbanística.

Portanto, com base no levantamento destas peculiaridades, se torna possível delinear e entender a complexidade econômica do estado para uma proposta de intervenção sustentável do design.

A complexidade deste estado tem uma relação com sua formação urbanística ou "fenômeno urbano", um termo adotado por Milton Santos.

Santos (2008. p. 65), define o "fenômeno urbano" como um processo de urbanização resultante do devido aparelhamento dos transportes, comunicação e mercado.

Todavia, para Machado (1999. p. 14), o "Fenômeno urbano" não um processo contínuo de ocupação, já que ocorrem variáveis distintas sobre as formações urbanas. Determinadas aglomerações, conforme Machado (1999. p. 14), não podem ser categorizadas como cidades. Também o urbanismo ocorrido na era pré-colonial do Amazonas é diferente do urbanismo atual.

$\mathrm{Na}$ formação urbanística, o mercado de trabalho é um vetor significativo para a constituição de novas cidades, como também um atrativo para a urbanização do território. Segundo Machado (1999. p. 1), o mercado de trabalho exerce rápidas mudanças nesta formação urbanística. O modo célere como estes deslocamentos acontecem provocam novas formas de organização das atividades produtivas, que conduzem a alterações na distribuição da população. Esta descrição, ainda segue um padrão de urbanização territorial, com suas devidas particularidades.

No caso da região amazônica, o povoamento é caracterizado pela ocupação nas margens dos rios Negro, Solimões-Amazonas, Madeira, Purus e Juruá, entre outros. Atraídos pela riqueza desta bacia, os portugueses e espanhóis, no século XVII, ocuparam os locais de maior população indígena. 
Desse modo, com o objetivo de conquistar o território dominado pela bacia hidrográfica, os portugueses fizeram alianças com os índios que, por sua vez, construíram vilas. Apesar da constatação de alianças e das edificações, estes feitos não foram significativos para a formação urbana da região. Esta afirmação é reiterada na fala de Machado:

De fato, desde a época colonial, sucessivos relatórios de governo indicavam que a autossuficiência das propriedades agrícolas, a dificuldade de comunicação, a baixa disponibilidade de mão-de-obra e a inexistência de complementaridade produtiva entre os subespaços amazônicos eram poderosos obstáculos ao crescimento das cidades.(MACHADO, 1999. p. 2)

Com base neste relato, percebe-se que, na época colonial, constatam-se as dificuldades existentes no estado do Amazonas, que até hoje têm ressonâncias na região.

$\mathrm{Na}$ verdade, a influência portuguesa em territórios indígenas não respaldou o urbanismo no Amazonas. O que marcou a gênese urbana na região foi a exploração extrativista da borracha a partir da segunda metade do século XIX e sua exportação para a Europa e para os Estados Unidos.

Foi o fenômeno comercial da borracha que marcou o surgimento de aglomerações de povoados no estado do Amazonas. Estes povoados tinham uma configuração precária resumida a ruas paralelas ao rio desprovidas de urbanização. As casas eram palafitas feitas de madeira em áreas alagadiças. Foi a expansão da economia da borracha que colaborou para modificar este povoamento rudimentar. Proporcionou uma estrutura sociopolítica, o que trouxe melhorias para a população, mas os benefícios não foram acessíveis para outra grande parte dos habitantes do estado.

Neste cenário, o desenvolvimento do estado ocorreu à custa de impactos ambientais e sociais. Houve iniciativas e investimentos por parte do governo federal. Construções de rodovias e criação de meios de comunicação foram relevantes para o surgimento de vilas, vilarejos e cidades. Nestes moldes, a cidade de Belém foi a maior favorecida com o comércio de exportação da borracha, e em seguida a cidade de Manaus.

O desenvolvimento urbanístico do Amazonas, de acordo com Machado (1999. p. 19), foi possível devido às inúmeras intervenções políticas e também por uma ordem espontânea, ou seja, uma "resultante das conexões entre as atividades do sistema de povoamento e a ação das instituições governamentais".

A partir da definição de urbanização, tanto no entendimento de Milton Santos, quanto na apreciação de Lia Osório Machado, pode-se fazer um esboço da ocupação territorial da floresta do Amazonas na atualidade. Esta ocupação é 
distinta pelo espaço geográfico e definida por dois tipos de aglomerações. Uma aglomeração encontra-se na margem do rio Negro conhecida como comunidades ribeirinhas, e a outra no interior da floresta, nomeada de comunidade afastada. Neste dois espaços geográficos, existem dois tipos de aglomeração diferentes, somados às comunidades indígenas que, em alguns momentos, estão homogeneizadas a estas aglomerações, e em outros se mantêm próximas, mas diferenciadas em termos de habitação (malocas), costumes, alimentação, modo de subsistência (caça e pesca), cultura, enfim, organização de comunidade.

Vale ressaltar que os ribeirinhos possuem uma infraestrutura de urbanização incipiente, ou no mínimo, uma estrutura capaz de receber o sistema urbanístico. Por outro lado, as comunidades afastadas possuem uma organização urbanística rudimentar.

A compreensão da geopolítica da Amazônia é necessária para que possamos discorrer sobre a intervenção do design na cadeia produtiva do açaí. A geopolítica compreende a relação entre o poder e o espaço geográfico.

Neste contexto, surgem algumas indagações que buscaremos responder no decorrer do texto. De que modo podem ser processados e interpretados os conflitos geográficos e políticos da Amazônia? Como é conferida a dinâmica do design inserida neste cenário político e geográfico? De que forma o design pode contribuir para o desenvolvimento de um modelo conceitual para a produção do açaí?

Como foi comentado anteriormente por Manzini (2008. p. 19), a sustentabilidade requer uma descontinuidade sistêmica, uma mudança no crescimento contínuo de seus níveis de produção e consumo material. Na visão de vários autores, são pronunciadas estas mudanças. No caso específico da Amazônia, a conjugação da mudança dos padrões de desenvolvimento, segundo Becker, é descobrir caminhos para equacionar o crescimento econômico com a conservação dos recursos naturais e a inclusão social.

Becker propõe três caminhos para solucionar esta equação definida pelo trinômio: crescimento econômico, recursos naturais e a inclusão social. Os caminhos são:

1. O novo significado geopolítico da Amazônia em âmbito global como a grande fronteira do capital natural;

2. O novo lugar da Amazônia no Brasil;

3. A urgência de uma nova política de desenvolvimento e de estratégias básicas para implementá-la. 
O design pode dar uma grande contribuição para a realização destes caminhos. No último item, fica mais evidente a possibilidade de sua colaboração. Isso porque o design reconhece a importância do envolvimento dos atores sociais na formação das estratégias em cenários de confronto entre o crescimento econômico e os recursos naturais, sem perder o foco na efetividade da inclusão social.

Becker (2005. p. 2) reitera este discurso sobre a necessidade de mudar os padrões de desenvolvimento quando afirma:

É imperativo o uso não predatório das fabulosas riquezas naturais que a Amazônia contém e também do saber das suas populações tradicionais que possuem um secular conhecimento acumulado para lidar com o trópico úmido. Essa riqueza tem de ser mais bem utilizada. Sustar esse padrão de economia de fronteira é um imperativo internacional, nacional e também regional. (BECKER, 2005. p. 2).

Neste sentido, a autora comenta o uso predatório das riquezas naturais da Amazônia e também traz outra questão relevante para o design: o "saber secular das populações tradicionais". Estes conhecimentos que os povos da floresta detêm, muitas vezes, são expressados de maneira não sistematizada, e até mesmo com outros nomes que são decodificados em determinados espaços geográficos, ou seja, os conhecimentos das populações não estão ordenados sob os cânones da ciência, nem por isso, são menos importantes. São saberes adquiridos ao longo do convívio na floresta. Neste sentido, o design pode reunir povos da floresta, técnicos, profissionais, ou seja, pessoas que estão envolvidas com diferentes saberes, em torno de um mesmo objetivo, de um mesmo projeto.

A Amazônia faz parte de um audacioso projeto de integração nacional, e como em todo grande projeto, ocorrem impactos negativos. Entretanto vale lembrar, segundo Becker (2005. p. 3), os aspectos positivos, como por exemplo a conexão da região com o restante do Brasil, por meio das estradas e também a facilidade trazida pela rede de telecomunicação, neste caso, chegando até a uma articulação internacional.

Outro aspecto positivo do projeto de integração nacional para a Amazônia é a conquista da industrialização e sobremaneira a Zona Franca, um marco geopolítico na opinião de Becker (2005. p. 3). Em síntese, a geopolítica da Amazônia pode ser resumida, na visão de Becker, da seguinte forma:

Hoje, a Amazônia não é mais mera fronteira de expansão de forças exógenas nacionais ou internacionais, mas sim uma região no sistema espacial nacional, com estrutura produtiva própria e múltiplos projetos de diferentes atores. Nela, a sociedade civil passou a ser um ator fundamental, tanto no campo como nas cidades, especialmente pelas suas reivindicações de cidadania, que inclusive influem no desenvolvimento urbano.(BECKER, 2005. p.13) 
A partir das visões de Santos, Machado e Becker, a geopolítica da Amazônia é trazida para auxiliar no entendimento da relação do poder público e do espaço geográfico com o processo de povoamento. Neste cenário complexo, são delineados os diversos fatores que contribuíram para o desenvolvimento econômico do estado do Amazonas.

Apesar da complexidade e das dificuldades encontradas no estado do Amazonas, verifica-se ser possível implementar iniciativas que são referências de modelos sustentáveis em cenários complexos, como por exemplo, a Fundação Amazonas Sustentável - FAS e a Zona Franca de Manaus - ZFM. Estes modelos sustentáveis serão discutidos a seguir.

\section{1}

\section{A Zona Franca de Manaus - ZFM}

A Superintendência da Zona Franca de Manaus (SUFRAMA) vinculada ao Ministério do Desenvolvimento, Indústria e Comércio Exterior (MDIC) é a estratégia de desenvolvimento regional que fortaleceu a economia na Amazônia Ocidental. A Zona Franca de Manaus - ZFM surgiu em 1957, criada pela Lei № 3.173 .

De acordo com Oliveira Jr. e Machado (2009. p. 32), a ZFM abrange dimensões territoriais com diferentes arranjos institucionais-legais, o que significa diferentes níveis de incentivos tributários, a saber: Sede da SUFRAMA Superintendência da Zona Franca de Manaus, Polo Industrial de Manaus (PIM), localizados na capital do estado do Amazonas, Manaus; ALCs - Áreas de livre comércio, presentes em localidades de fronteira nos municípios de Macapá e Santana (Estado do Amapá), além dos estados do Acre, Amazonas, Rondônia e Roraima; e Coordenações Regionais. Estas dimensões territoriais fazem parte da Amazônia Ocidental (Figura 2). 


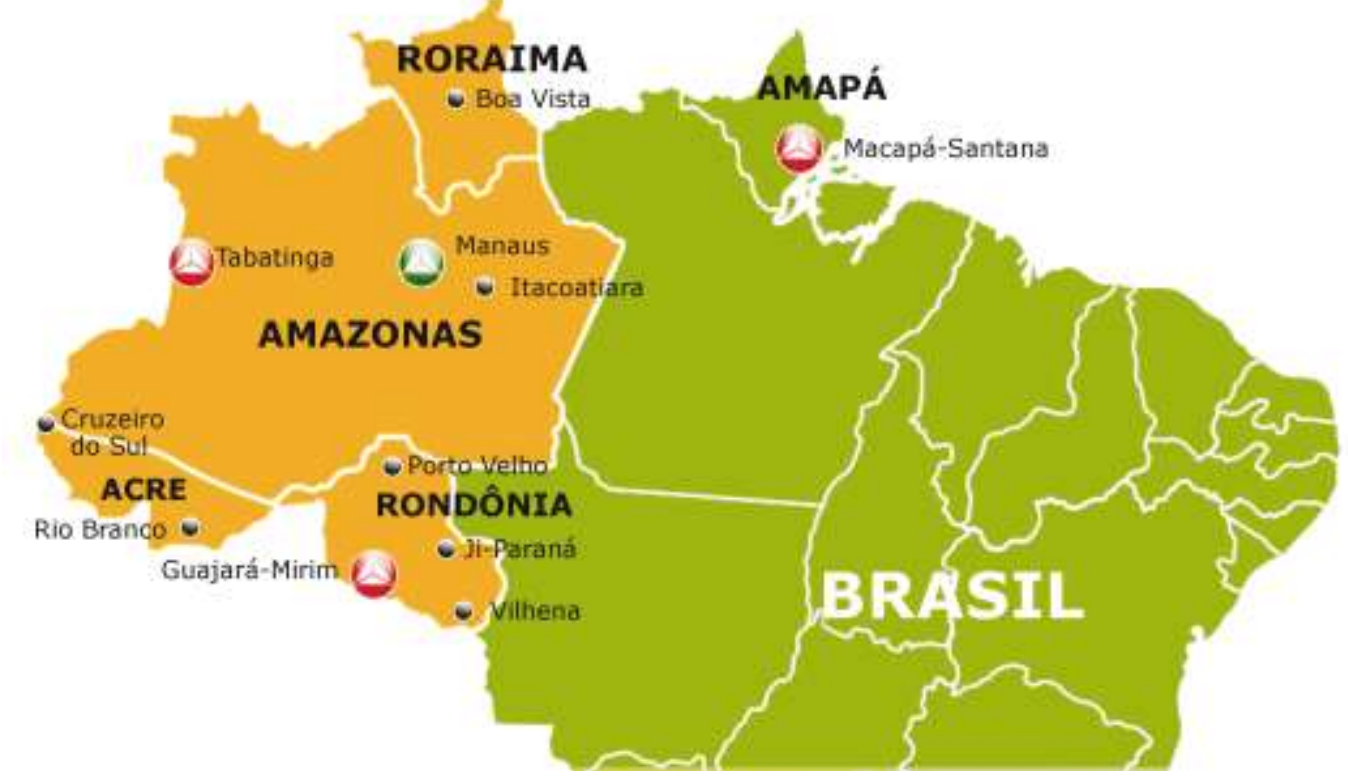

\begin{tabular}{|c|c|}
\hline$\Leftrightarrow$ & Sede da SUFRAMA, Polo Industrial de Manaus (PIM) \\
\hline$\Leftrightarrow$ & Áreas de livre comércio - ALCs \\
\hline \multirow[t]{2}{*}{$\varphi$} & Coordenações Regionais \\
\hline & Amazônia Ocidental \\
\hline
\end{tabular}

Figura 2 - Dimensões territoriais da Amazônia Ocidental e localização de diferentes arranjos institucionais-legais

Fonte - Figura adaptada de Oliveira Jr. e Machado (2009. p. 33). Elaboração: SUFRAMA/COGEC.

A Zona Franca de Manaus - ZFM compreende uma área de $10 \mathrm{mil} \mathrm{km}^{2}$ localizada na capital Amazonense, sua intervenção inclui: os estados do Amazonas, do Acre, de Roraima, de Rondônia e os municípios de Macapá e de Santana, no Amapá.

Com base na filosofia de incentivos fiscais, no ano de 1989, foram criadas as Áreas de Livre Comércio - ALCs com o objetivo de proporcionar o desenvolvimento das cidades com fronteiras internacionais localizadas na Amazônia Ocidental.

A ZFM é relevante não só para a economia regional, mas também nacional. Os benefícios são revelados na geração de renda e garantia de empregos para milhares de brasileiros.

Conforme Oliveira Jr. e Machado (2009. p. 33 e 34), foram quatro fases distintas que a ZFM enfrentou até chegar ao modelo presente.

- A primeira fase teve início no ano de 1957 e se estendeu até 1967 e foi marcada pelo entreposto comercial do tipo "Porto Livre". 
- A segunda fase teve início no ano de 1967 e se estendeu até 1975 , sendo o período de criação de mercado interno para bens finais distinto, pela atração de empresas internacionais, majoritariamente em eletrônica de consumo.

- A terceira fase teve início no ano de 1975 e se estendeu até 1990 e foi caracterizada pela substituição de importações em ambiente de concorrência restrita.

- A quarta fase teve início no ano de 1990 e se estende até a atualidade, sendo um período marcado pela modernização industrial hightech em ambiente capitalista internacionalizado.

$\mathrm{Na}$ atualidade, a ZFM adere à Política de Desenvolvimento Produtivo (PDP) em paralelo com a Política Industrial Tecnológica e de Comércio Exterior (PITCE), que busca maior produtividade e capacidade de inovação das empresas e expansão das exportações.

O parque industrial da ZFM detém uma produção diversificada com mais de 600 empresas, produzindo com tecnologia de ponta. São vários produtos fabricados ou montados na ZFM, itens como: motocicletas, televisores, celulares, tablets, videogames, bicicletas, condicionadores de ar, blu-ray players, smartphones, bicicletas, barbeadores, isqueiros, canetas, relógios e xaropes dos refrigerantes Coca-Cola e Pepsi. Grandes marcas estão alocadas na ZFM como: Samsung, LG, Honda, Yamaha, Harley-Davidson, Gillete e BIC.

O polo de Duas Rodas, por exemplo, é um setor de destaque em instalação final de componentes, onde existem mais de 70 fábricas atuando nos seguintes processos de fabricação: fundição, estamparia, usinagem, solda, pintura e injeção plástica.

De acordo com Rios (2015. p. 24), a ZFM é reconhecida como estratégia de desenvolvimento regional eficaz que realizou uma base econômica sólida na Amazônia Ocidental.

Diante deste sucesso da ZFM como um modelo econômico estratégico que emprega, integra e distribui riquezas na região, o governo federal vem aprovando a ampliação de prazos para incentivos fiscais que já passa por uma quarta prorrogação:

1. A primeira prorrogação foi no ano de 1986, através do Artigo 1ํ do Decreto 92.560, que estendeu por 10 anos o prazo que passou a valer até o ano de 1997; 
2. A segunda prorrogação se deu no ano de 1988, por meio do Artigo 40 do Ato das disposições Constitucionais Transitórias - ADCT, com validade dos incentivos fiscais por 25 anos (até 2013);

3. A terceira prorrogação ocorreu no ano de 2003, com a edição da Emenda Constitucional no 42, e estendeu os incentivos fiscais da Zona Franca de Manaus por mais 10 anos, passando a ter validade até o ano de 2023;

4. A quarta prorrogação foi no ano de 2014, por meio da Emenda Constitucional 83/2014, por mais 50 anos, o que compreende o período de incentivos fiscais entre 2023 até 2073.

Vale ressaltar que as prorrogações dos prazos dos incentivos fiscais foram aprovadas antes de suas vigências acabarem, independentemente de períodos consecutivos, como mostra a Figura 3.

$\begin{array}{lllllll}1986 & 1988 & 1997 & 2003 & 2013 & 2014 & 2023\end{array}$

$1986-1997$

$1988-2013$

Figura 3 - Prorrogações dos incentivos fiscais da Zona Franca de Manaus. Fonte - Figura adaptada do Portal Brasil (informativo eletrônico).

\section{2}

\section{Fundação Amazonas Sustentável - FAS}

No contexto desta tese, cabe discorrer sobre a Fundação Amazonas Sustentável - FAS e a realização dos seus projetos em diversas áreas, sobremaneira, na saúde e na educação. Isso porque a iniciativa se apresenta como um exemplo de que é possível realizar projetos sustentáveis em localidades envolvidas em conflitos de ordem geopolítica. Inicialmente, para termos uma ideia geral destes conflitos, lembramos que estamos falando de uma região com extensa área territorial e proporcionalmente com baixa densidade demográfica, com difícil locomoção e acessibilidade. Este panorama é o suficiente para concluir que as intervenções projetuais são executadas com grandes esforços.

A Fundação Amazonas Sustentável, com base nas informações coletadas no sítio eletrônico da $F A S^{1}$, é uma organização brasileira sem fins lucrativos, não

\footnotetext{
${ }^{1}$ Sítio eletrônico da Fundação Amazonas Sustentável - FAS: http://fas-amazonas.org/mensagens/
} 
governamental, de utilidade pública estadual e federal (Portaria MJ № 3.098 de 26/09/2013). Foi criada em 20 de dezembro de 2007, por meio de uma parceria entre o governo do estado do Amazonas e o Banco Bradesco.

A prioridade da FAS compreende a conservação do meio ambiente e a melhoria da qualidade de vida das comunidades ribeirinhas do estado do Amazonas. A FAS tem como superintendente geral o Sr. Virgílio Viana, especialista em Amazônia, mudanças climáticas, manejo florestal e agroflorestal, conservação ambiental, certificação e desenvolvimento sustentável.

A FAS realiza diversos projetos fundamentados nos princípios da sustentabilidade social, econômica e ambiental, atuando em 574 comunidades (Tabela 2 e Figura 4), que incluem localidades isoladas, distantes e empobrecidas da Amazônia brasileira. Com a implementação dos projetos, é observado o aumento da renda familiar no manejo do pirarucu, castanha, madeira, cacau, açaí, borracha, óleos vegetais, agricultura e turismo de base comunitária. Estatisticamente, com as Unidades de Conservação Beneficiadas, houve uma redução de ocorrências tanto no desmatamento, quanto nos focos de incêndio florestal.

\begin{tabular}{|c|c|c|c|c|}
\hline & Unidade de conservação & Área (ha) & Famílias & $\begin{array}{l}\text { Comunidades/ } \\
\text { localidades }\end{array}$ \\
\hline \multirow{7}{*}{$\begin{array}{l}\text { Regional } \\
\text { Negro- } \\
\text { Amazonas }\end{array}$} & 1. RDS Piagaçu - Purus & $1.008,167$ & 1.032 & 65 \\
\hline & 2. RDS do Rio Negro & 103.086 & 559 & 19 \\
\hline & 3. APA do Rio Negro & 611.008 & 135 & 8 \\
\hline & 4. RDS Puranga Conquista & 79.936 & 201 & 8 \\
\hline & 5. RDS do Uatumã & 424.430 & 393 & 20 \\
\hline & 6. FLOREST de Maués & 438.440 & 800 & 21 \\
\hline & 7. RDS Canumã & 22.355 & 322 & 16 \\
\hline \multirow{3}{*}{$\begin{array}{l}\text { Regional } \\
\text { Madeira }\end{array}$} & 8. RDS do Rio Madeira & 283.117 & 1.027 & 56 \\
\hline & 9. RDS do Rio Amapá & 216.109 & 436 & 10 \\
\hline & 10. RDS do Juma & 589.611 & 494 & 38 \\
\hline \multirow{3}{*}{$\begin{array}{l}\text { Regional } \\
\text { Solimões }\end{array}$} & 11. RDS Mamirauá & 1.124 .000 & 2.312 & 177 \\
\hline & 12. RDS Anamã & 2.350 .000 & 868 & 64 \\
\hline & 13. RESEX Catuá Ipixuna & 217.486 & 255 & 13 \\
\hline \multirow{4}{*}{$\begin{array}{l}\text { Regional } \\
\text { Juruá-Jutaí }\end{array}$} & 14. RESEX do Rio Gregório & 308.859 & 192 & 27 \\
\hline & 15. RDS Cujubim & 2.450 .380 & 53 & 2 \\
\hline & 16. RDS de Uacari & 632.949 & 332 & 30 \\
\hline & Total & 10.856 .933 & 9.411 & 574 \\
\hline
\end{tabular}

RDS - Reserva de Desenvolvimento Sustentável

RESEX - Reserva extrativista

APA - Área de Proteção Ambiental

FLOREST de Maués - Floresta Estadual de Maués

Tabela 2 - Áreas de atuação da FAS.

Fonte - Relatório de atividades 2014 da Fundação Amazonas Sustentável - FAS. 


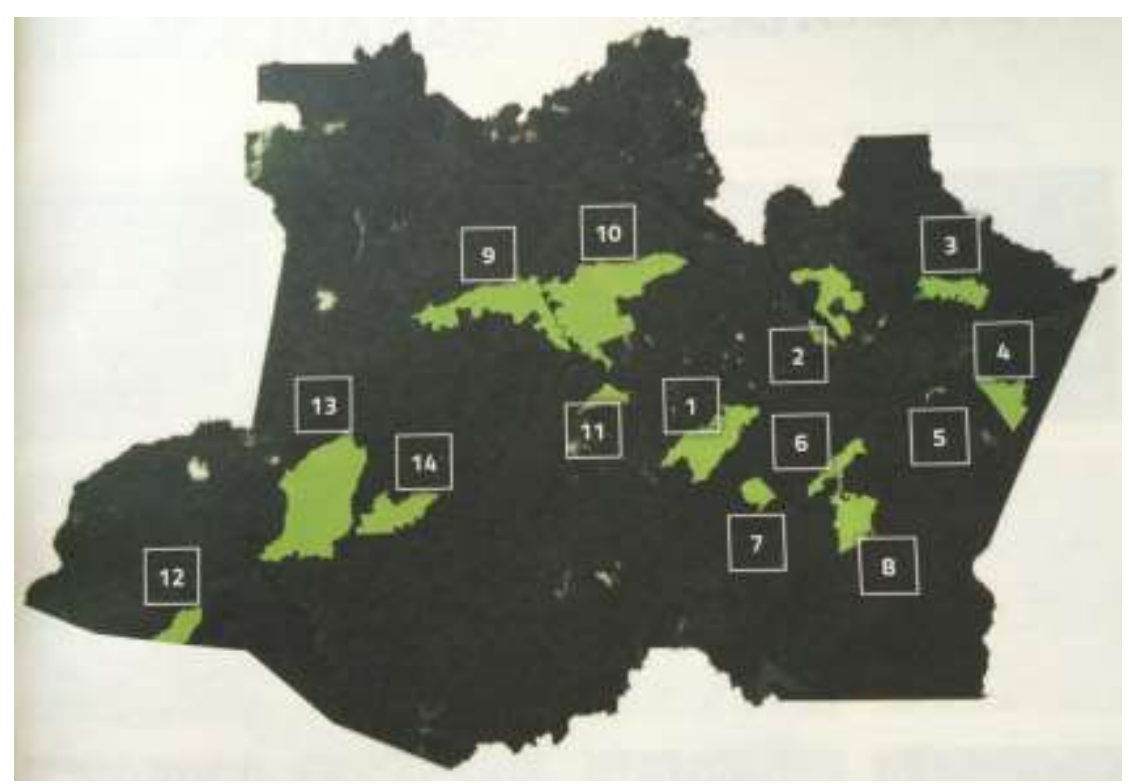

Figura 4 - Mapa das áreas de atuação da FAS.

Fonte - Relatório de atividades 2014 da Fundação Amazonas Sustentável - FAS.

A FAS é constituída por 12 Reservas de Desenvolvimento Sustentável RDS; 2 Reservas extrativistas - RESEX; 1 Área de Proteção Ambiental - APA e 1 Floresta Estadual de Maués - FLOREST de Maués, no total de 16 (dezesseis) localidades, como mostra a Tabela 2.

Existem também 9 Núcleos de Conservação e Sustentabilidade - NCS que são organizados com um ancoradouro, posto de saúde, escola, centro comunitário, laboratório multiuso, laboratório digital, central de energia solar, banco expresso, igreja, horta e viveiro, pousada, mercearia, casa do artesanato, alojamento de aluno, casa do professor e centro vocacional para o desenvolvimento sustentável.

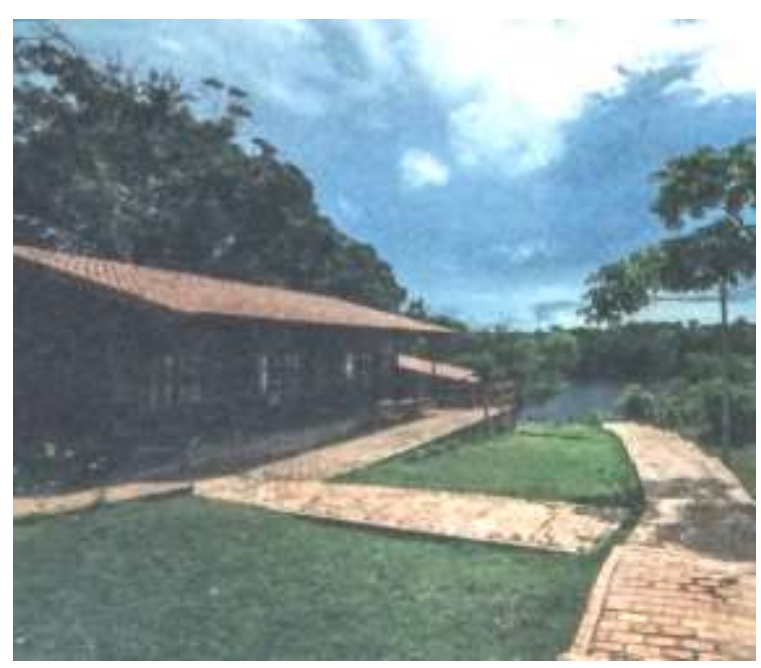

Figura 5 - Núcleo Ângelo Uchôa Bitencourt.

Fonte - Relatório de atividades 2014 da Fundação Amazonas Sustentável - FAS. 


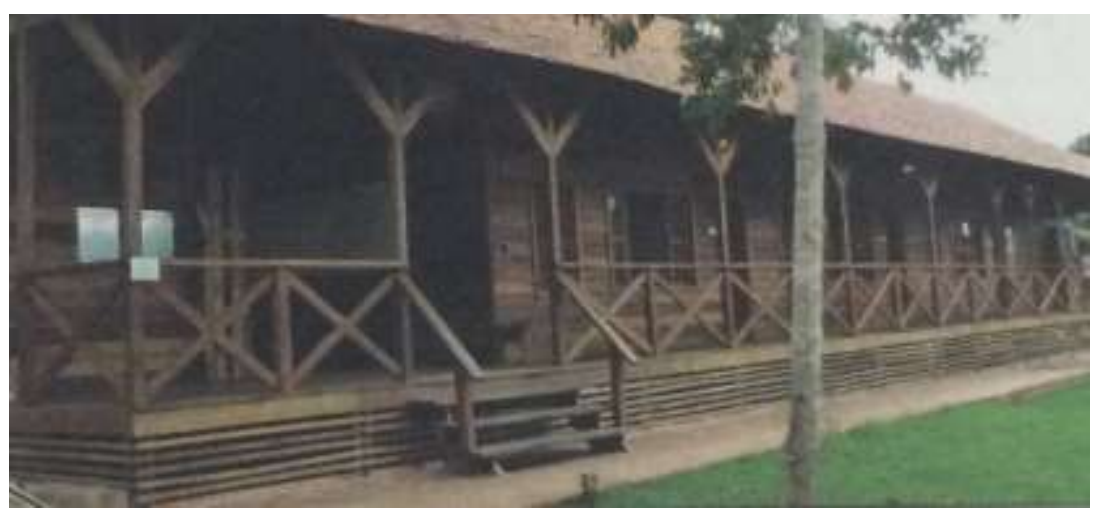

Figura 6 - Núcleo Assy Manana.

Fonte - Relatório de atividades 2014 da Fundação Amazonas Sustentável - FAS.

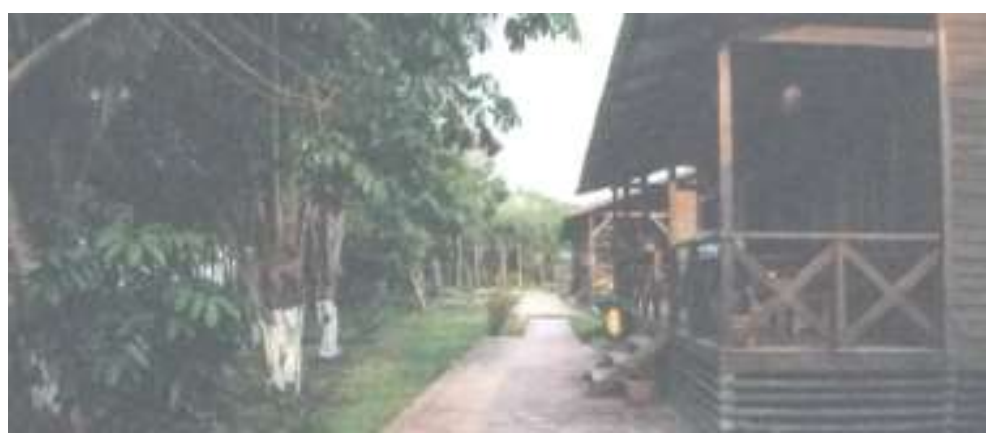

Figura 7 - Núcleo Uatumã.

Fonte - Relatório de atividades 2014 da Fundação Amazonas Sustentável - FAS.

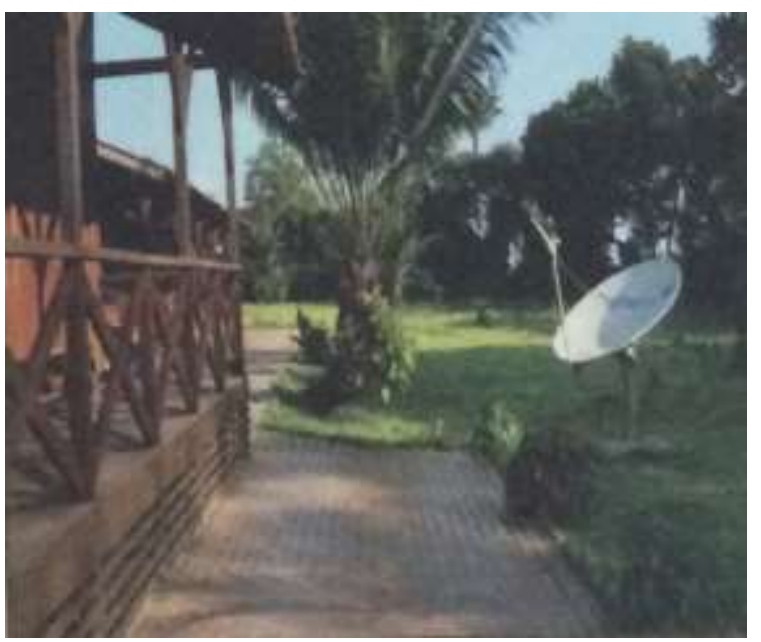

Figura 8 - Núcleo Samuel Benchimol.

Fonte - Relatório de atividades 2014 da Fundação Amazonas Sustentável - FAS. 


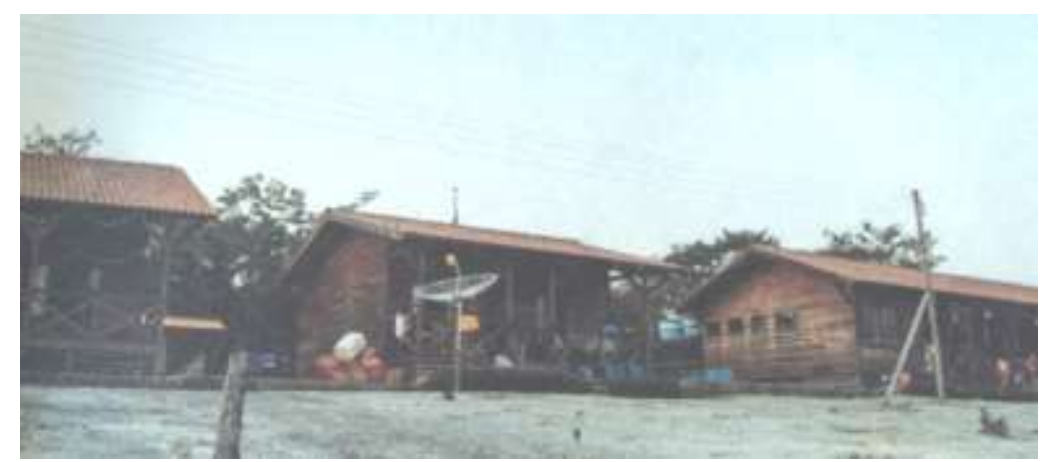

Figura 9 - Núcleo Victor Civita.

Fonte - Relatório de atividades 2014 da Fundação Amazonas Sustentável - FAS.

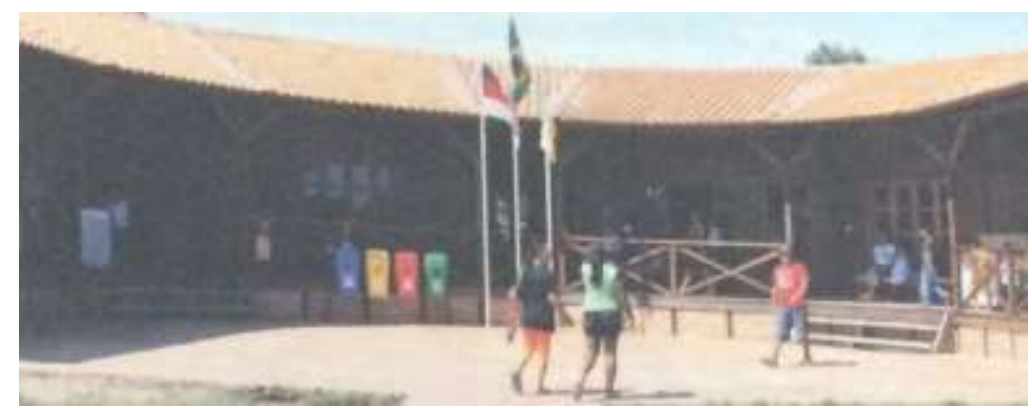

Figura 10 - Núcleo Professor Márcio Ayres.

Fonte - Relatório de atividades 2014 da Fundação Amazonas Sustentável - FAS

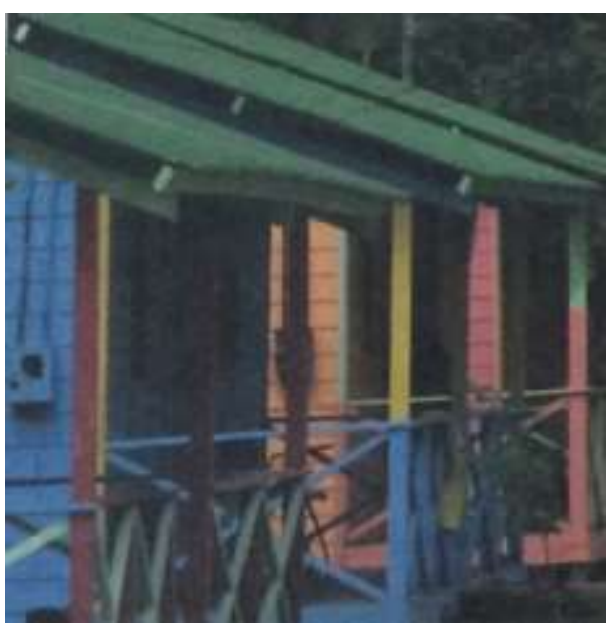

Figura 11 - Núcleo Vila Cujubim.

Fonte - Relatório de atividades 2014 da Fundação Amazonas Sustentável - FAS 


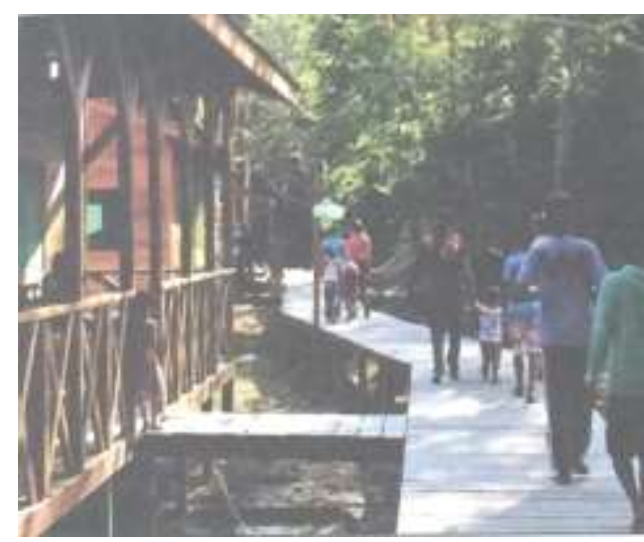

Figura 12 - Núcleo Bertha Becker.

Fonte - Relatório de atividades 2014 da Fundação Amazonas Sustentável - FAS

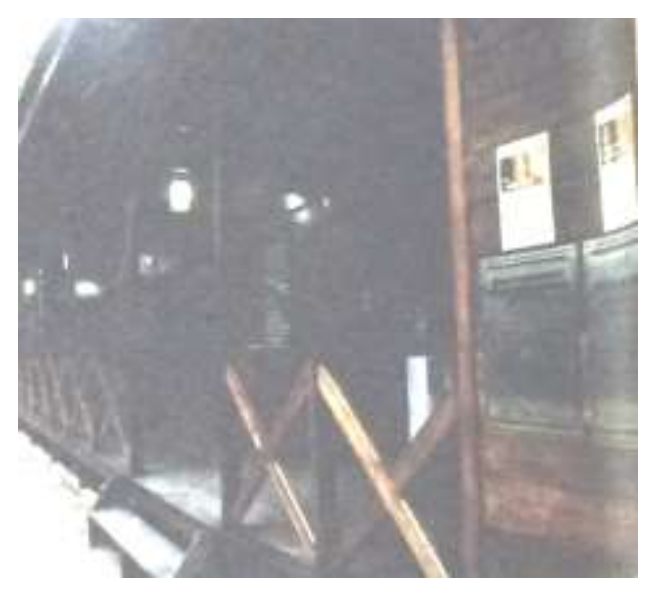

Figura 13 - Núcleo Padre João Derickx.

Fonte - Relatório de atividades 2014 da Fundação Amazonas Sustentável - FAS

As iniciativas da FAS são representadas pelo Programa Bolsa Floresta (PBF), pelo Programa de Educação e Saúde (PES) e pelos Programas de Solução Inovadora (PSI). As ações da FAS compreendem projetos de geração de renda, projetos de apoio à melhoria de qualidade de vida e de oficinas de planejamento participativo. Esses projetos são realizados nos Núcleos de Conservação, com regularidade, oferecendo cursos Técnicos de Produção Sustentável que são reaplicados para a população ribeirinha e indígena.

A FAS coordena ainda uma iniciativa denominada Rede de Soluções para o Desenvolvimento Sustentável para a Amazônia (SDSN - Amazônia), que tem a finalidade de debater soluções práticas para os países amazônicos.

Os Programas de Solução Inovadora (PSI) abrangem soluções para comunidades isoladas do Amazonas a partir do desenvolvimento e adaptações conectadas com os saberes das populações tradicionais. Estas intervenções priorizam a conservação ambiental e a inclusão social. Além desses, outros 
aspectos valorizados são o respeito à diversidade cultural e à igualdade de gênero.

Os recursos do Programa Bolsa Floresta, por sua vez, são destinados aos arranjos produtivos sustentáveis e aplicados de forma participativa. Este gerenciamento financeiro compreende a flexibilidade administrativa da FAS, que atende à compra de equipamentos, infraestrutura, atendimento, serviços e cursos de capacitação. A finalidade é otimizar as atividades econômicas existentes nas cadeias produtivas e criar outras com base nos preceitos da sustentabilidade. As principais cadeias produtivas são: açaí, cacau, pirarucu, castanha da Amazônia, óleos vegetais, borracha, madeira manejada, artesanato e o turismo de base comunitária.

Segundo o Relatório de Atividades 2014 (p. 80), a FAS executou 2 projetos para as cadeias produtivas do açaí e óleo vegetal da andiroba, com o suporte financeiro da Videolar S/A e do Comitê das Atividades de Pesquisa e Desenvolvimento na Amazônia - CAPDA. Os projetos encontram-se configurados como Projetos de Pesquisa, Desenvolvimento e Inovação - PD\&I. O objetivo é encontrar melhorias produtivas e qualitativas para as cadeias produtivas, por intermédio da inovação tecnológica. O projeto foi desenvolvido na RDS Uacari, em Carauari, com produtores ribeirinhos, lideranças atuantes no Território Médio Juruá, a Associação dos moradores da RDS Uacari e egressos do curso pósmédio de produção sustentável em unidades de conservação.

O projeto foi dividido em duas etapas: a primeira etapa abordou as boas práticas agroextrativistas para a cadeia produtiva do açaí e o desenvolvimento de dispositivos e equipamentos para maior produtividade com maior segurança para os agricultores, o que resultou em um equipamento para a colheita do açaí. A segunda etapa compreende o planejamento para a construção de um laboratório experimental de beneficiamento de óleos vegetais e do açaí. 


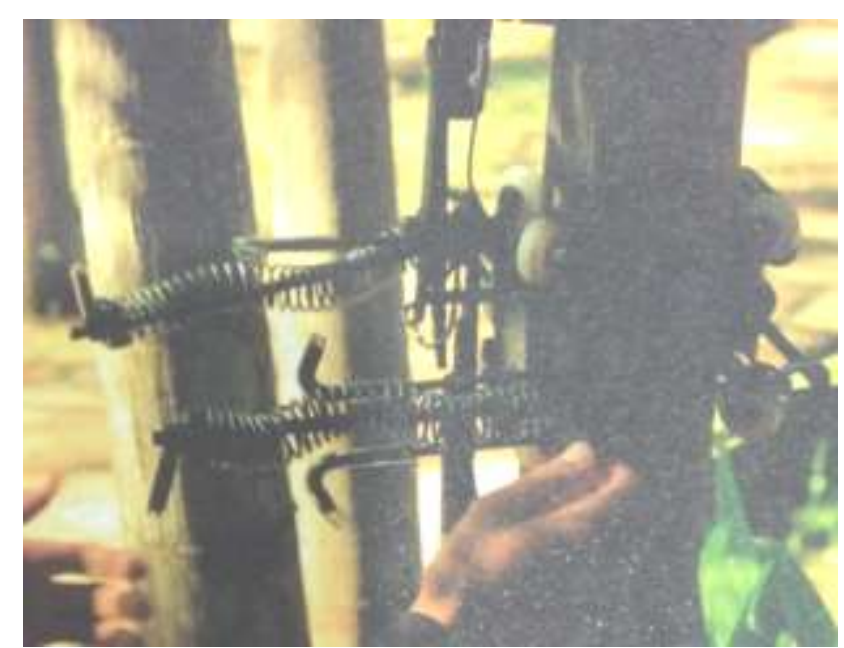

Figura 14 - Protótipo de "tiradeira" de açaí.

Fonte - Relatório de atividades 2014 da Fundação Amazonas Sustentável - FAS.

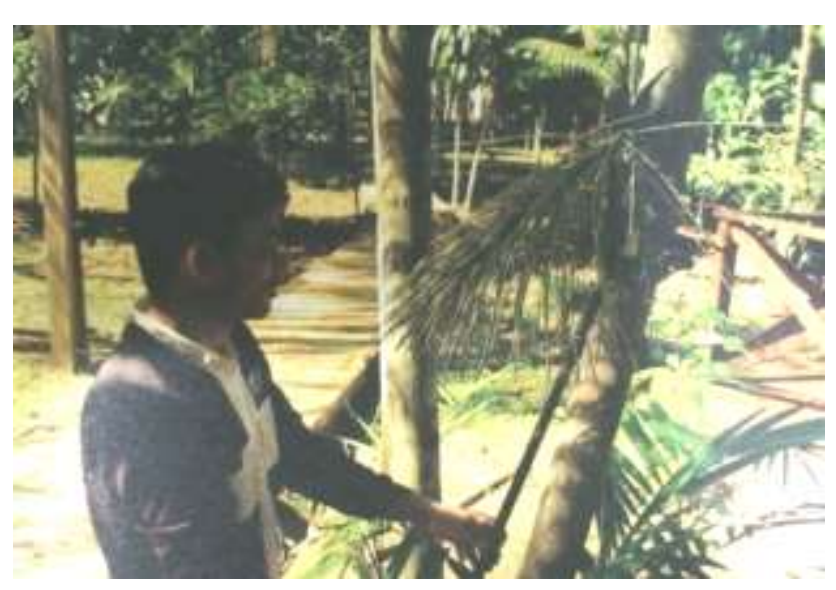

Figura 15 - Protótipo de "tiradeira" de açaí (simulação de uso).

Fonte - Relatório de atividades 2014 da Fundação Amazonas Sustentável - FAS.

O protótipo de "tiradeira" de açaí (Figura 14), resultante do projeto PD\&l, compreende um dispositivo que é fixado ao açaizeiro e deslizado na palmeira por meio de um sistema de roldanas, que controla a subida e a descida do mesmo. $O$ equipamento possui uma guilhotina que faz o corte do cacho, em seguida, este é preso por cordas que descem até o solo. Tal equipamento apresenta vantagens, pois evita a escalada, proporcionando segurança; outra vantagem é o aumento da retirada dos cachos no açaizeiro, o que favorece a redução de esforços físicos humanos e proporciona segurança, tornando a coleta de cachos de açaí mais rápida. Por outro lado, apresenta algumas desvantagens, uma vez que a fixação do equipamento no açaizeiro é complicada, exigindo certa destreza para tal atividade, somada à ineficácia da guilhotina no corte.

Apesar de o equipamento apresentar alguns complicadores que inviabilizam sua efetiva aplicabilidade, como um projeto de PD\&I, a iniciativa é considerada 
válida por se tratar de um objeto de estudo suscetível a otimizações em projetos vindouros, e também por ser um exercício de tecnologia apropriada.

No próximo capítulo, um estudo sobre a cadeia produtiva do açaí e suas principais atividades é apresentado, considerando seus impactos ambientais.

\section{3}

\section{Novas formas de entendimento do espaço rural}

O espaço rural, denominado também campo, meio rural e zona rural, compreende um espaço geográfico destinado para a prática de atividades agropecuárias, agroindustriais, extrativismo, silvicultura e conservação ambiental. Desta forma, entende-se que a conservação ambiental abrange também as terras indígenas e a conservação extrativista.

O entendimento de espaço rural vem, entretanto, se expandindo, e hoje agrega também o conceito de turismo rural, que por sua vez sugere novas frentes de trabalho e colabora com a permanência da população no campo, evitando a evasão rural.

O turismo promove a circulação de pessoas para lugares distintos das suas moradias, em viagens com a finalidade de lazer. Estas viagens oportunizam conhecimentos a respeito da cultura, da política, dos costumes, da culinária, entre outros aspectos relacionados ao modo de viver de determinada sociedade.

O turista carrega consigo sua experiência e conhecimento de vida, consequentemente, estabelece comparações entre o seu modo de viver e o modo de viver do local visitado. Esta analogia é um efeito positivo do turismo que traz à tona os valores culturais da cidade e dos seus habitantes.

Todo esse processo de conhecimento, que o turismo promove, revela afinidades como também estranhamentos entre o turista e o local visitado. E, esse conhecimento advindo do turismo, muitas vezes permite um modo particular de perceber o outro, mais atento e respeitoso com as diferenças culturais.

Neste sentido, o turismo se configura como um processo de aprendizagem, que se propaga para todos os modelos de turismo incluindo 0 turismo rural.

O empreendimento turístico no espaço rural expande a economia da região, mantendo a população no campo e atraindo novos moradores. Na opinião de Elesbão et al. (2014. p. 1), o turismo rural favorece o desenvolvimento local com base na conservação ambiental: 
O turismo no espaço rural é uma atividade que dentro do contexto da multifuncionalidade da agricultura pode representar uma importante estratégia de desenvolvimento local, possibilitando a dinamização dos espaços rurais, a preservação da natureza e o surgimento de novos postos de trabalho. (ELESBÃO, 2014. p. 1)

Um grande feito do turismo rural é favorecer o resgate e a valorização dos costumes e das tradições da vida do campo. Para Elesbão et al. (2014. p. 1), esse fato permite ao ruralista agregar valor aos produtos e serviços rurais, evidenciando as vantagens advindas do turismo rural da mesma forma que favorece o setor econômico. Tais vantagens se estendem também às dimensões social e ambiental dentre outras. Conforme Klein (2012, apud ELESBÃO et all 2014. p. 2), muitos são os benefícios do turismo rural, como por exemplo no âmbito social, a possibilidade de interação entre os extratos sociais e a permuta de experiências; e na dimensão ambiental, a preservação do meio rural e a promoção da educação ambiental.

O turismo rural se apresenta, portanto, como uma ferramenta que oportuniza conhecer o espaço rural e observar a dinâmica das atividades nele realizadas, desse modo, constatando a dura realidade do campo, e o trabalho árduo que os ruralistas realizam no seu cotidiano. Estas constatações fazem os turistas valorizarem as atividades realizadas na zona rural, como também apreciarem os ruralistas e os moradores do campo.

Nesse contexto, a prática do turismo rural promove benfeitorias tanto para os turistas quanto para os atores locais, embora de modos distintos. Os turistas, a partir de um exercício de alteridade, passam a valorizar os ruralistas e seu modo de vida; enquanto os atores locais encaram o turismo rural como um processo endógeno, passando a entender seu papel e suas responsabilidades diante do meio em que vivem, e a perceber que são formadores da sua história, da sua cultura e responsáveis pela preservação dos recursos naturais que os circundam.

O turismo rural, também conhecido como ecoturismo, está inserido no relatório da Cúpula da Terra (comentado no capítulo 2), assim como o turismo cultural. Tanto o ecoturismo, quanto o turismo cultural são mencionados como sub temas que devem ser inseridos no contexto do design, para que a atuação projetual se estenda do âmbito do produto e possa adotar uma abordagem sistêmica de maior amplitude, favorecendo outros segmentos como o social e o ambiental.

Neste sentido, trazemos o turismo rural e o turismo cultural como referências para um planejamento de grande amplitude social e ambiental, e 
também como práticas a serem revistas como alternativas para implementação no modelo conceitual para a produção do açaí. 
4.

\section{Modelo produtivo do açaí (Euterpe precatoria)}

No presente capítulo, apresentamos o modelo produtivo do açaí (Euterpe precatoria), que compreende a exploração comercial da polpa extraída do fruto e utilizada como matéria-prima para a indústria alimentícia, abrangendo as seguintes atividades: a colheita, a extração dos frutos no cacho (debulhamento), o acondicionamento, o processamento da polpa (despolpamento), o transporte, o consumo e o descarte das sementes. Serão também abordados: o fruto e suas características, os aspectos gerais da palmeira, o cultivo e as atividades envolvidas no modelo.

\section{1}

\section{0 fruto do açaí}

O fruto do açaí é formado pela polpa, semente e fibras. $O$ fruto apresenta uma morfologia arredondada de cor roxa (Figura 16), aproximadamente com 8,5 $\mathrm{mm}$ de diâmetro. $\mathrm{O}$ fruto nasce em cachos (Figura 17a) que brotam abaixo das folhas das palmeiras. Os cachos são formados por ramificações denominadas ráquilas (Figura 17b), que são retiradas da palmeira, e os frutos debulhados das ráquilas manualmente.

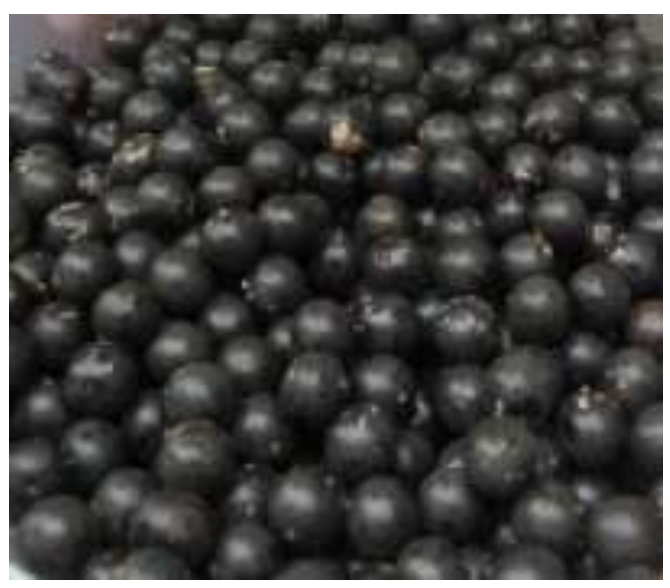

Figura 16 - Fruto do açaí. 

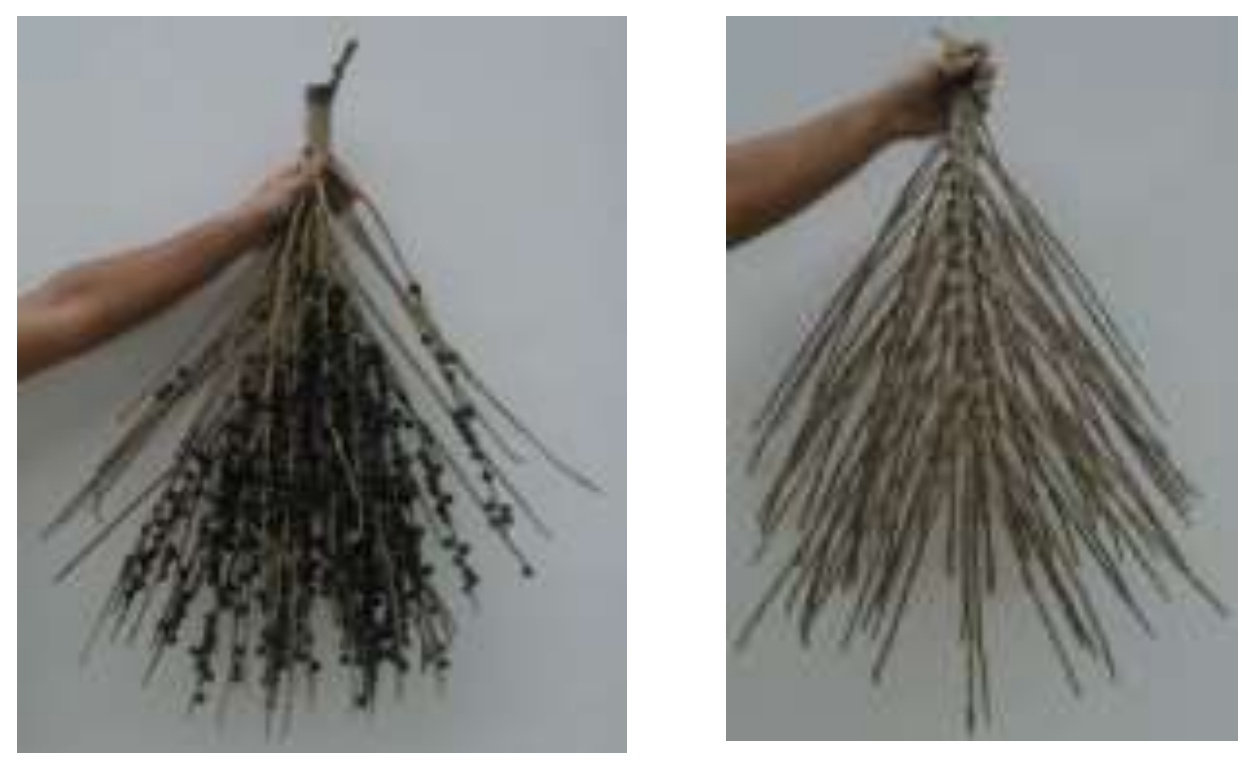

Figuras 17a e 17b - (a) Cacho com frutos do açaí e (b) Cacho sem frutos (debulhado).

Para uma melhor compreensão, serão analisadas, separadamente, as partes constituintes do fruto do açaí que, basicamente, compreendem três partes: o mesocarpo, o epicarpo e o endocarpo (Figura 18). O mesocarpo é a parte comestível do fruto, ou seja, a polpa. O epicarpo são as fibras, constituídas por uma fina película conhecida por casca, e por fim, o endocarpo, que corresponde à semente (caroço).

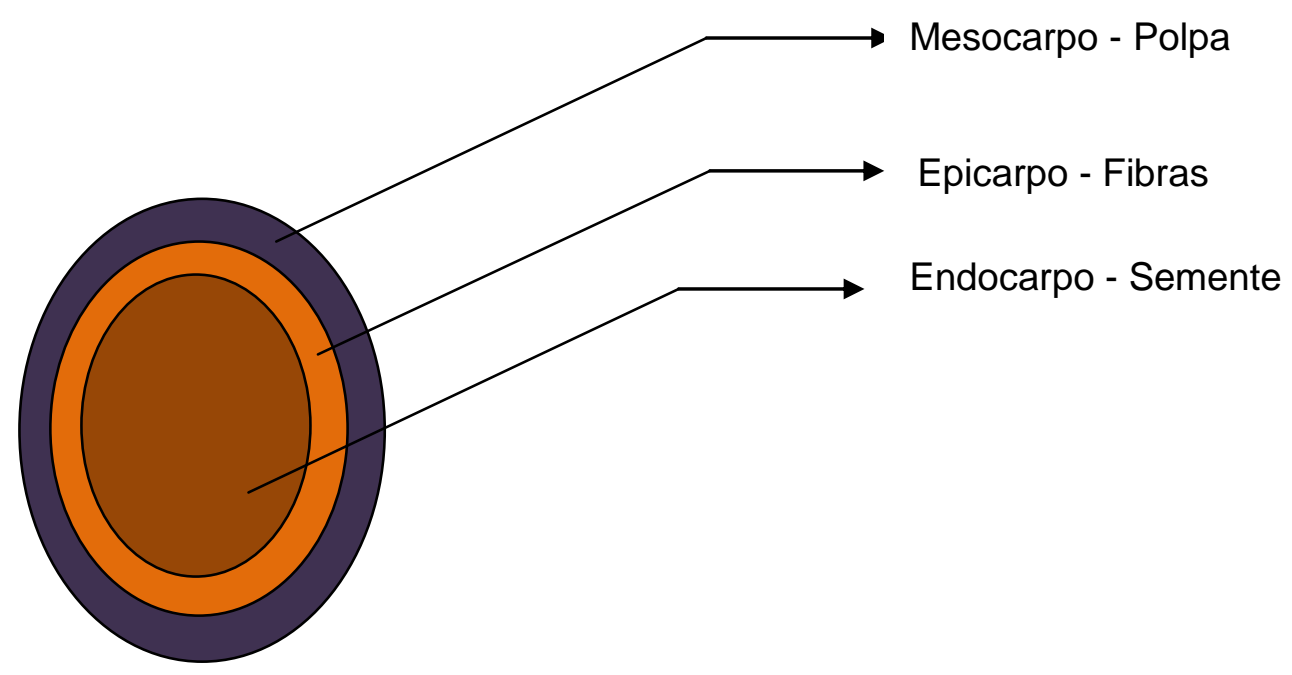

Figura 18 - Partes do fruto do açaí. 


\subsection{1}

\section{Mesocarpo}

O mesocarpo encontra-se acoplado à semente. É a polpa, a parte comestível do fruto. A polpa tem um vasto emprego na indústria de alimentos devido ao seu alto valor energético e nutricional. Com ela, são feitos suco, licor, doce e bombom, entre outros produtos do gênero alimentício.

Para facilitar a remoção da polpa, as sementes são submetidas ao processo de maceração, ou seja, são submersas em tanque com água por duas horas. Após este período, as sementes são colocadas em máquinas despolpadeiras para a retirada do mesocarpo da semente. A polpa (Figura 19), também conhecida como vinho de açaí, produz um suco denso que pode ser diluído em água potável.

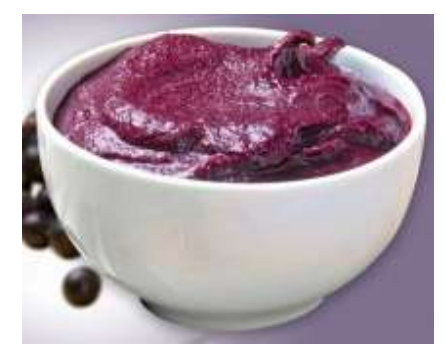

Figura 19 - Mesocarpo (polpa) do fruto do açaí.

Fonte - http://poderdasfrutas.com/conheca-os-beneficios-do-acai/acai-na-tigela/

\subsection{2}

\section{Epicarpo}

O epicarpo é formado por uma camada fina, a casca, e sobre ela existe um feixe de fibras que envolvem as sementes de uma extremidade à outra.

As fibras possuem uma cor marrom. Em algumas partes, estão dispostas de forma ordenada e, em outras, se comportam de forma irregular, apresentando uma forma desalinhada, o que pode ser observado na Figura 20.

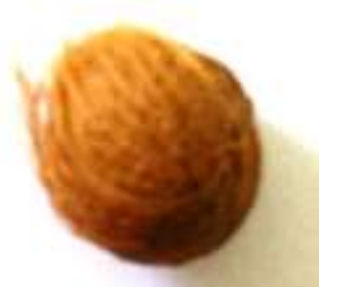

Figura 20 - Epicarpo (fibras e casca sobre a semente). 
A casca é bastante frágil, formada por uma película ligada às fibras. Devido a estas características, fica difícil separar a casca das fibras (Figuras 21a e 21b) cuja extração é feita pelo processo de desfibramento.

O prolongamento da fibra percorre de uma extremidade à outra da semente. O seu comprimento mede aproximadamente $12 \mathrm{~mm}$.
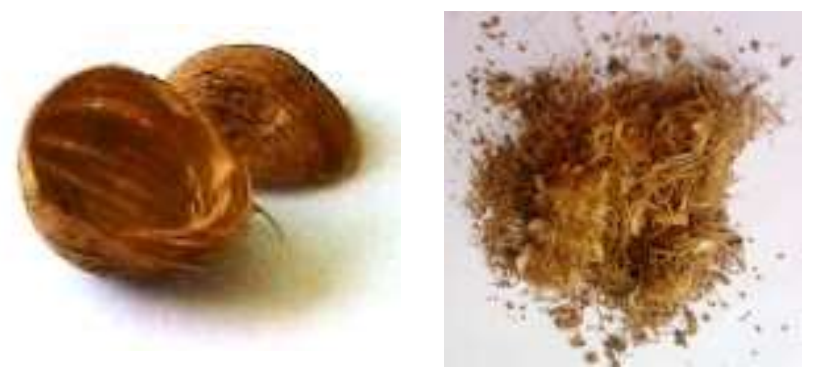

Figuras 21a e 21b - (a) Casca sobre a semente e (b) Casca e fibra extraídas da semente.

\subsection{3}

\section{Endocarpo}

O endocarpo é formado apenas pela semente que fica localizada no interior do fruto. Possui uma coloração escura, próxima da cor preta (Figura 22), e seu diâmetro mede 8,5 mm conforme Quirino (2010. p. 55).

A semente beneficiada apresenta uma coloração diferente após ser submetida ao processo de lixamento e polimento do caroço (Figuras $23 a$ e 23b). As sementes beneficiadas e tingidas são utilizadas em artesanato.
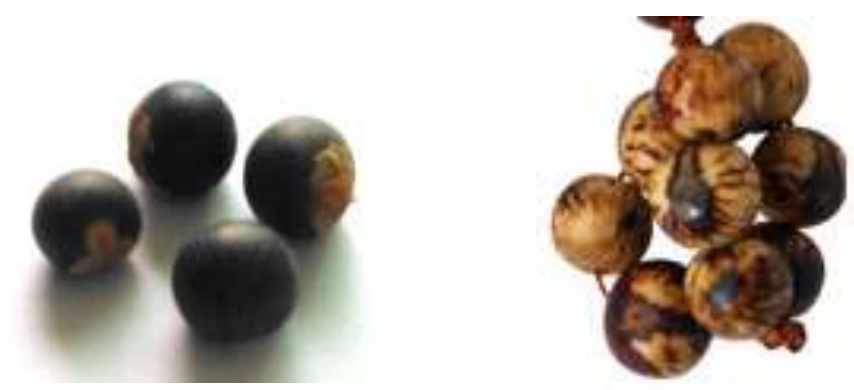

Figuras 23a e 23b - (a) Sementes (endocarpo) e (b) Sementes beneficiadas. 


\section{2}

\section{Palmeira do açaí (Euterpe precatoria)}

O açaizeiro (Figura 24) é uma palmeira típica da Amazônia brasileira de clima tropical. É encontrado em áreas alagadas, próximas a igarapés, igapós e também em terra firme. Na literatura, são mais comentadas três espécies de açaizeiro: Euterpe oleracea (Floresta Amazônica), Euterpe precatoria (Floresta Amazônica) e Euterpe edullius martius (Floresta Atlântica). A palmeira, também, é cultivada em países da América do Sul (Venezuela, Colômbia, Equador, Suriname e Guiana) e da América Central (Panamá).

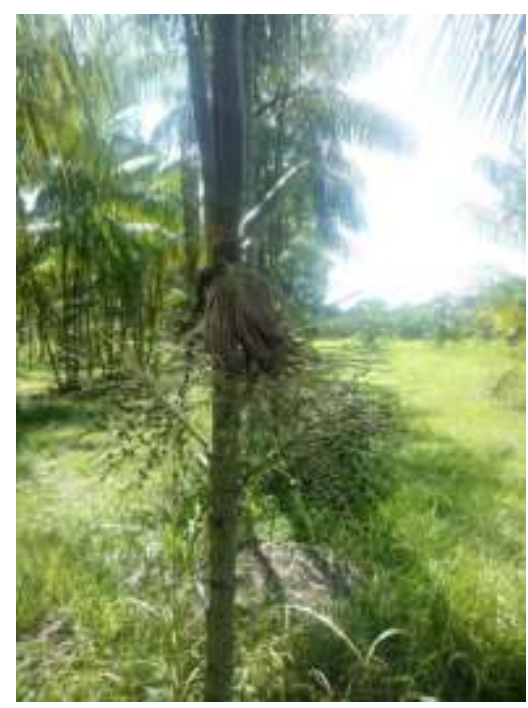

Figura 24 - Açaizeiro (Euterpe precatoria).

A condição favorável para o plantio é a regularidade das chuvas que mantêm a umidade no solo. Por essa razão, as áreas de várzea são as mais indicadas para o plantio do açaizeiro. Com condições apropriadas, o açaizeiro começa a produzir frutos a partir de 3 a 4 anos de idade, conforme Vasconcelos e Alves (2006).

A palmeira é formada por folhas, frutos, raiz e caule (estipe). Cada parte da palmeira possui aproveitamento específico, a saber: as sementes e as folhas são destinadas ao uso em artesanato, como adubo e como ração animal; os cachos são utilizados na confecção de vassouras; o caule do açaizeiro é empregado na construção de casas; a raiz é utilizada no combate à malária e, por fim, a polpa é consumida como alimento.

O caule (estipe), em fase adulta, pode atingir 12 a 20 metros de altura e possuir $14 \mathrm{~cm}$ (quatorze centímetros) de diâmetro. 
A palmeira pode crescer com um único estipe (Figura 25a) ou pode ter de quatro a oito estipes. Quando isso acontece, a palmeira é denominada açaí touceira (Figura 25 b).
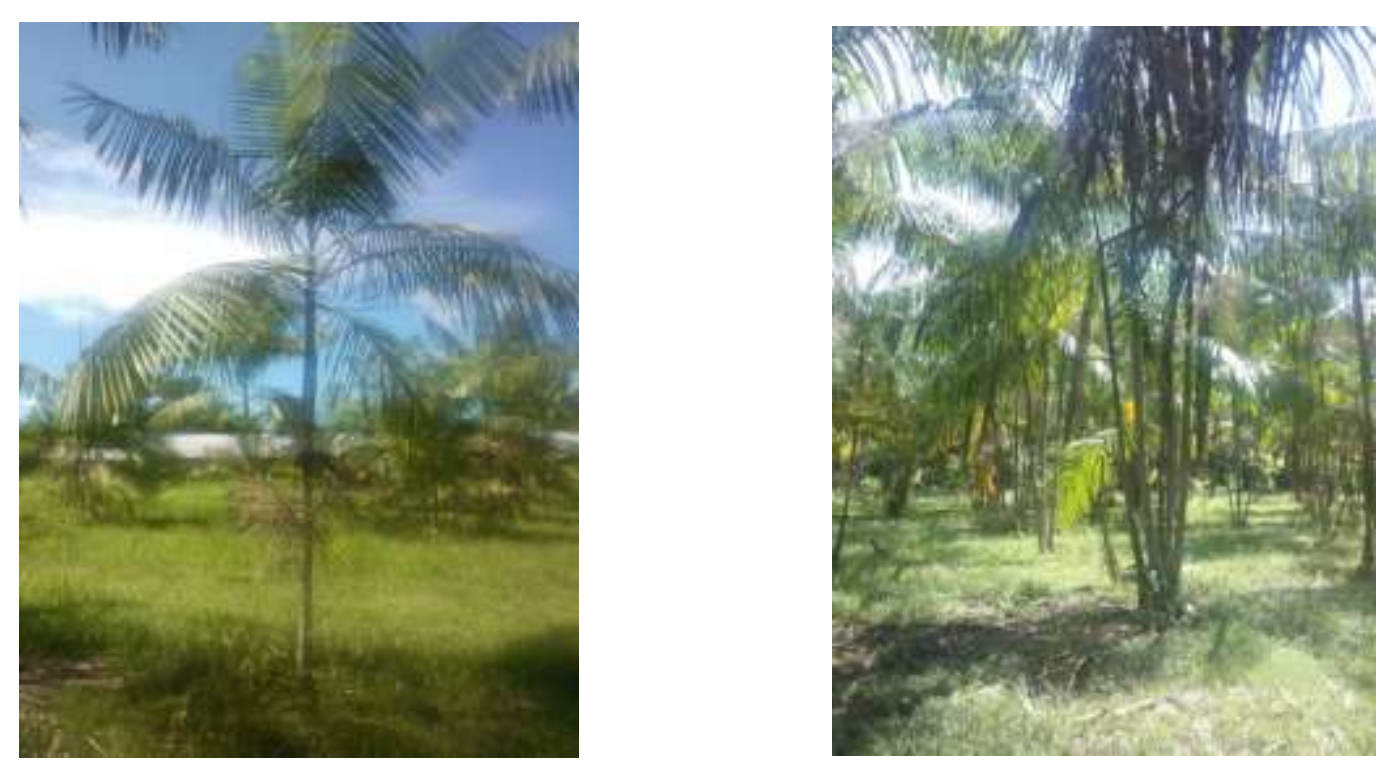

Figura 25a e 25b - (a) Palmeira com um estipe e (b) Palmeira touceira.

\section{3}

\section{Cultivo do açaí}

As sementes do açaí são recalcitrantes, ou seja, perdem a capacidade germinativa quando secas ou estocadas. Por esta razão, Farias Neto et al. (2006) recomendam que as sementes sejam plantadas após o despolpamento, com o propósito de assegurar a germinação. Tal característica é encontrada em determinados grupos de sementes. A maioria das sementes, em contraposição, deve ser estocada e armazenada para potencializar sua capacidade embrionária.

Para uma compreensão abrangente do cultivo da palmeira na região de Manaus, faz-se necessário colocar em pauta a problemática da floresta amazônica.

Como é sabido, o solo da floresta amazônica é pobre em nutrientes, e esta carência é atenuada devido ao volume de chuvas existente na região. Para suprir a insuficiência de nutrientes do solo, alguns técnicos agrícolas buscam o uso de defensivos agrícolas e pesticidas. Todavia, esta prática agrícola é antagônica ao método orgânico, no qual se evita o emprego de substâncias químicas, e são adotados procedimentos menos agressivos ao meio ambiente. A facilidade promovida pelo emprego dos defensivos, seja no provimento dos nutrientes, seja 
no combate às pragas, muitas vezes, é a opção determinante para a seleção do método.

Uma agricultura orgânica, por exemplo, abrange sistemas de produção que eliminam o emprego de fertilizantes sintéticos, defensivos agrícolas, aditivos químicos e hormônios, assim como evita insumos externos reduzindo a contaminação do ambiente e dos alimentos. A prática orgânica aprecia os princípios da sustentabilidade a favor dos recursos naturais como: solo, água e ar, abrangendo o desenvolvimento socioeconômico da comunidade.

No Brasil, conforme Yamanaka (2012. p. 11), a agricultura orgânica foi reconhecida e regulamentada no ano de 1999 pelo Ministério da Agricultura Pecuária e Abastecimento (MAPA). As informações técnicas necessárias para o cultivo de açaizeiros com base na agricultura orgânica podem ser encontradas na Instrução Normativa no 64 , de 2008, ao passo que o extrativismo orgânico é regulamentado com base na Instrução Normativa Conjunta oㅜ 17, de 2009. De acordo com esta regulamentação, o extrativismo sustentável orgânico segue os seguintes princípios:

I - conservação dos recursos naturais;

II - manutenção da estrutura dos ecossistemas e suas funções;

III - manutenção da diversidade biológica;

IV - desenvolvimento socioeconômico e ambiental local e regional;

$\mathrm{V}$ - respeito à singularidade cultural dos povos e a comunidades tradicionais $\mathrm{e}$ a agricultores familiares;

VI - destinação adequada dos resíduos de produção, buscando ao máximo o seu aproveitamento.

Observando a Instrução Normativa Conjunta no 17, de 2009, verifica-se a conformidade da regulamentação com o conteúdo desta pesquisa. Todos os seus princípios estão condizentes com este trabalho, principalmente os últimos itens. $\mathrm{O}$ item seis está relacionado com a proposta inicial que aponta o aproveitamento total das sementes, ou seja, propõe um destino adequado para os resíduos do modelo conceitual para a produção do açaí.

$\mathrm{O}$ açaizeiro pode ser cultivado de duas maneiras, seja pela retirada de perfilhos (assexuada), seja pelo plantio das sementes (sexuada), de acordo com Farias Neto et al. (2006). Os perfilhos são ramos que se desenvolvem nas laterais das estipes, na superfície do solo. Ainda para o mesmo autor, o cultivo com sementes é o processo mais recomendado economicamente, pois permite produzir grande número de mudas com menor custo, quando comparado à propagação assexuada. 
A germinação das sementes, de acordo com Farias Neto (2006), pode ser feita em camadas estratificadas com serragem de madeira, diretamente em sacos de plástico preto, ou em sementeira (viveiro). A finalidade da serragem é manter a umidade na muda.

Para o cultivo, é retirado o mesocarpo (polpa), ficando apenas o epicarpo (fibras) e o endocarpo (sementes) para seguirem com o processo de semeadura.

Conforme Müller (2006), o preparo do solo pode ser por meio de roçagem manual ou mecanizada. O mais indicado para o cultivo do açaizeiro, quando compartilhado com culturas de ciclo curto, é a roçagem mecanizada, que tem a finalidade de minimizar custos.

O cultivo do açaizeiro é recomendado em sistemas de plantio solteiro e consorciado $^{2}$, conforme Nogueira (2006), com espécies frutíferas e/ou florestais, como mostra a Figura 26.

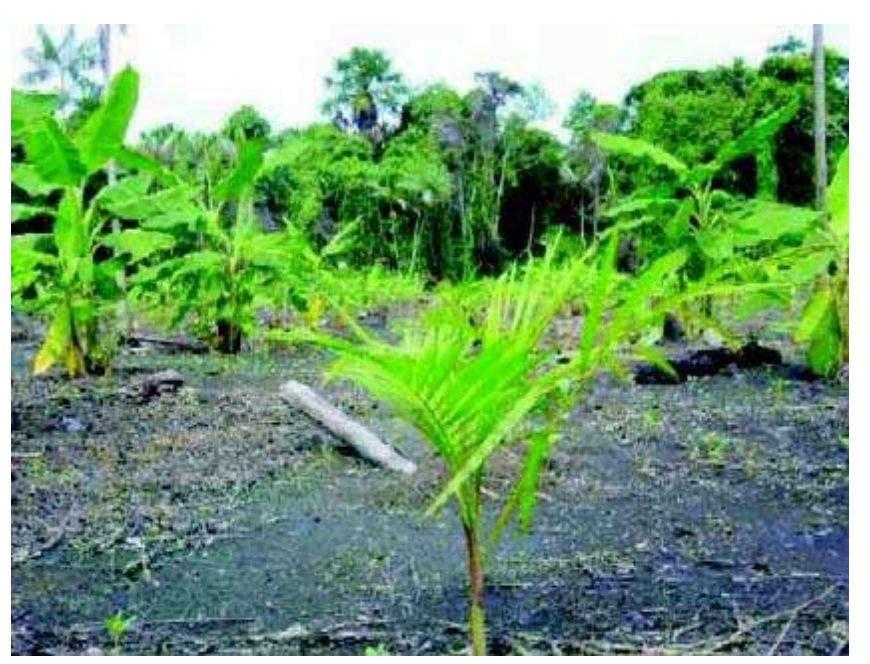

Figura 26 - Área de várzea com sistema consorciado de açaizeiro e bananeira. Fonte - Embrapa Amazônia Oriental, Nogueira (2006).

Neste sistema de cultivo consorciado nas áreas de várzea, segundo Nogueira (2006), o açaizeiro é apontado como elemento principal para o ecossistema, devido à sua facilidade de recompor a cobertura florística, além da sua relevância alimentar e econômica para as populações ribeirinhas.

A Comissão Estadual de Sementes e Mudas do Pará, conforme Farias Neto et al. (2006), instituiu as seguintes normas para as mudas com sementes:

${ }^{2}$ Plantio solteiro e consorciado compreende o cultivo de culturas diferentes numa mesma área. Técnica para diversificar e reduzir os prejuízos mediante a frequente irregularidade climática das regiões. 
1. Apresentar altura uniforme, aspecto vigoroso, cor e folhagem harmônicas;

2. Possuir, no mínimo, cinco folhas fisiologicamente ativas (maduras), pecíolos longos e as folhas mais velhas com folíolos separados. O coleto deve apresentar a espessura da base maior que a da extremidade das mudas;

3. Ter de 4 a 8 meses de idade, a partir da emergência das plântulas;

4. Apresentar altura de 40 a $60 \mathrm{~cm}$, medidos a partir do colo da planta;

5. Apresentar sistema radicular bem desenvolvido e ter suas extremidades aparadas quando ultrapassar o torrão;

6. Estar isenta de pragas e moléstias (Regulamento da Defesa Sanitária Vegetal);

7. Permitir a comercialização das mudas somente em torrões, acondicionadas em sacos de plástico, sanfonados e perfurados, ou equivalentes, com, no mínimo, 15 $\mathrm{cm}$ de largura e $25 \mathrm{~cm}$ de altura.

Nesta pesquisa, na realização dos experimentos, que serão abordados no capítulo 4, adotaremos como referência as normas da Comissão Estadual de Sementes e Mudas do Pará, por termos verificado a inexistência de normas do estado do Amazonas.

\section{4}

\section{Atividades do modelo produtivo do fruto do açaí}

A cadeia produtiva do açaí que, em última instância, consiste na exploração comercial da polpa extraída do fruto como matéria-prima para a indústria alimentícia, inclui várias e distintas atividades. Essas atividades, realizadas por agricultores familiares ou empresários da agroindústria, são incorporadas e transmitidas de geração a geração, com as devidas adaptações, ajustando-se às limitações regionais e à tecnologia disponível.

O produto final deste modelo, a coleta e venda de frutos para as indústrias processadoras, têm sido bastante valorizado, resultando na movimentação da economia regional. Segundo Homma (2006), a população ribeirinha admite que a produção e a comercialização de seu fruto in natura são os produtos mais lucrativos fornecidos pelo açaizeiro.

Será utilizado como referência o fluxograma representativo do processo de obtenção da polpa de açaí, desenvolvido por Bacellar (2006. p. 4) (Figura 27), vinculado ao Centro de Desenvolvimento Energético Amazônico - CDEAM, para elaborar um organograma da cadeia produtiva do açaí.

O fluxograma representativo do processo de obtenção da polpa de açaí faz parte do projeto do CDEAM, intitulado: "Modelo de Negócio de Energia 
Elétrica em Comunidades Isoladas na Amazônia - NERAM", que tem como objetivo geral o aproveitamento do fruto do açaizeiro para geração de energia elétrica em comunidades isoladas na Amazônia.

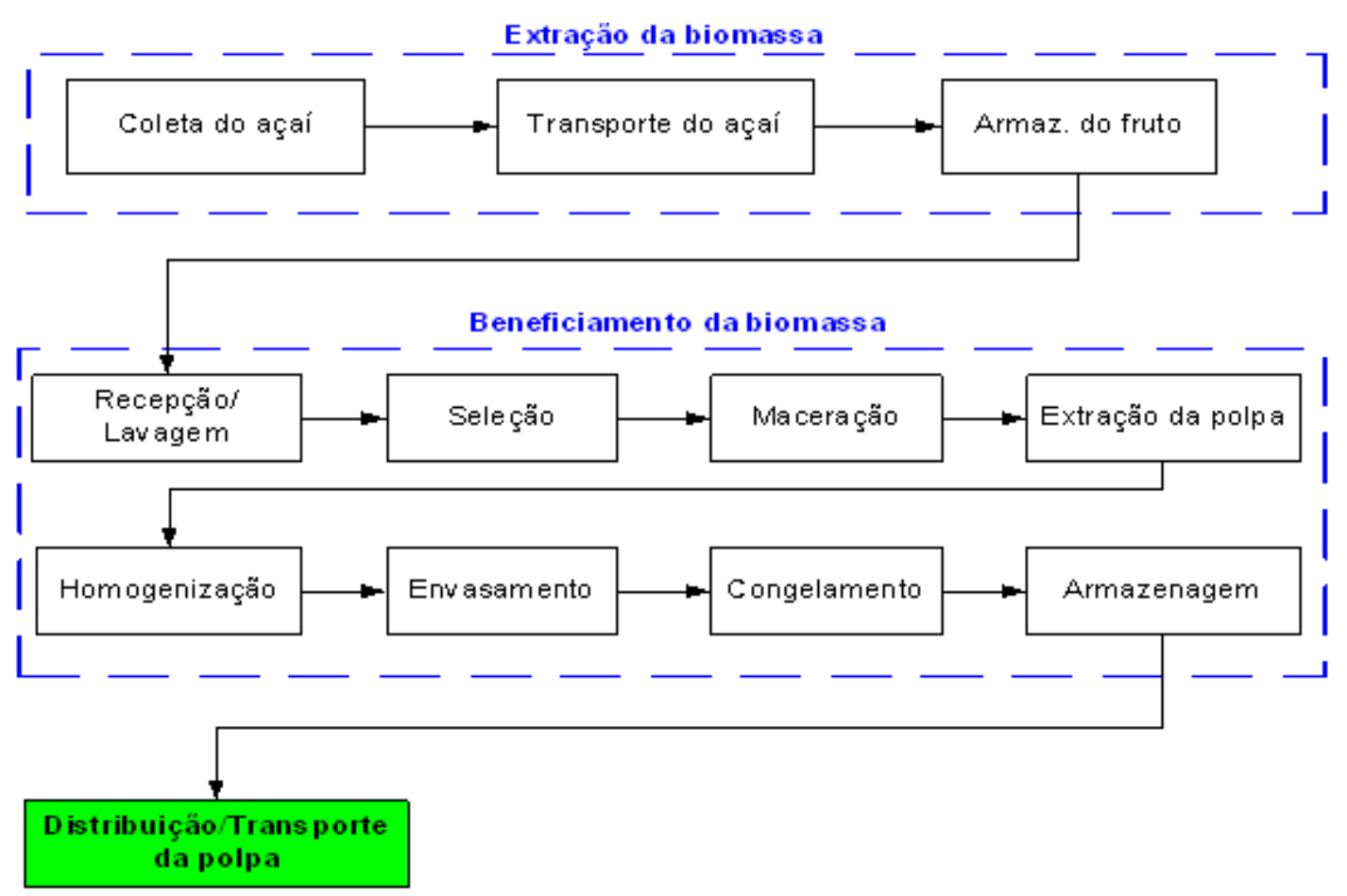

Figura 27 - Fluxograma representativo do processo de obtenção da polpa de açaí.

Fonte - Bacellar et al. (2006. p. 4).

O fluxograma desenvolvido pelo CEDEAM (Figura 29) divide a cadeia em duas etapas: a extração da biomassa e o beneficiamento da biomassa. A primeira etapa compreende a coleta do açaí, transporte e armazenamento do fruto. A segunda etapa consiste em: recepção/lavagem, seleção, maceração, extração da polpa, homogeneização, envasamento, congelamento e armazenagem.

Com base neste fluxograma, foram selecionadas algumas das etapas mais representativas da cadeia produtiva do açaí e inseridas outras atividades. Desse modo, foi delineado um organograma determinado pelas atividades da cadeia produtiva do açaí. Este organograma é um modelo de estudo que será utilizado para prever e avaliar os impactos ambientais em cada etapa da cadeia. Tal organograma compreende as seguintes etapas: a colheita do açaí, o debulhamento, o despolpamento, o acondicionamento, o transporte, o consumo e o descarte das sementes e fibras (Figura 28). 


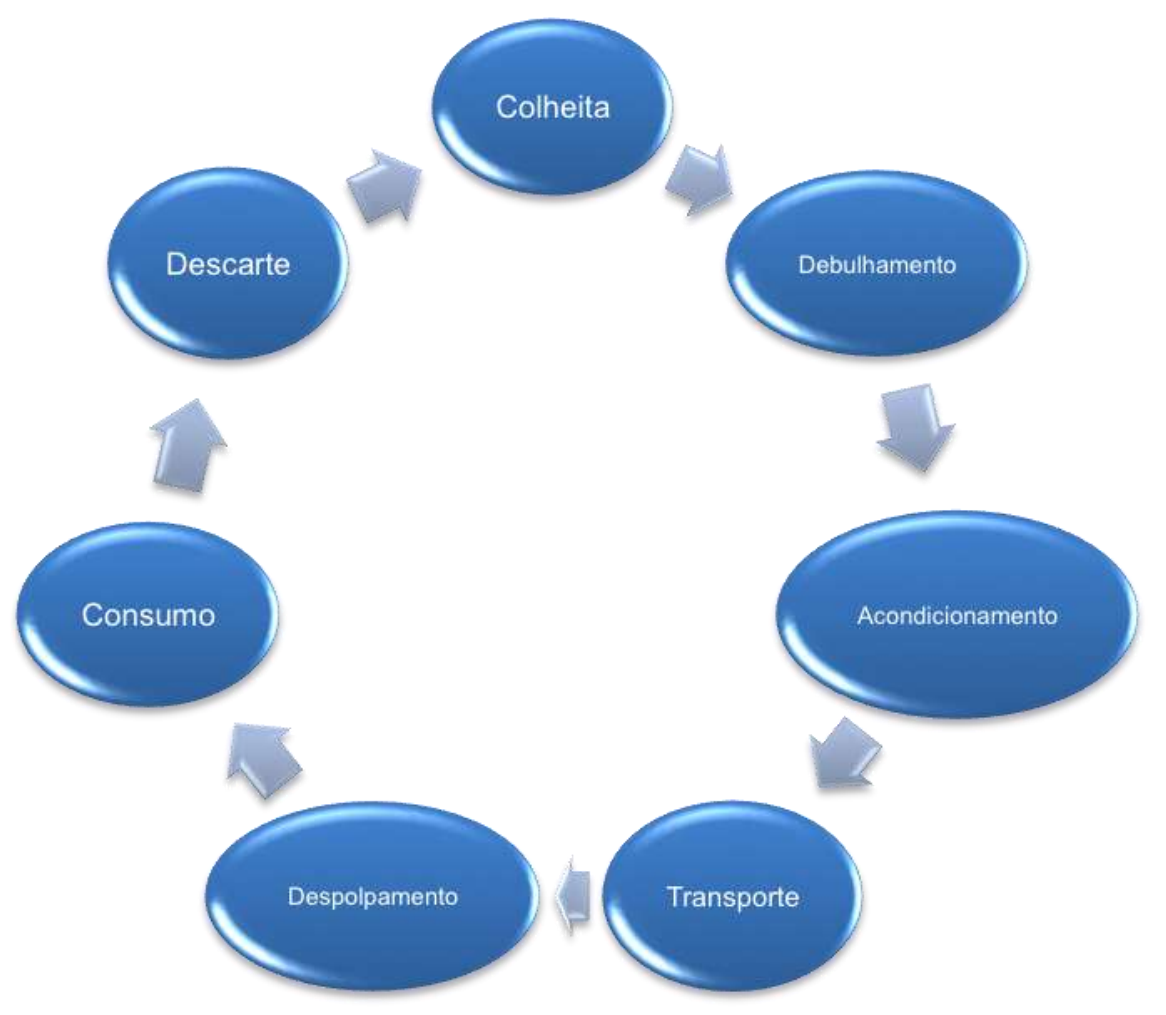

Figura 28 - Organograma das atividades da cadeia produtiva do açaí. Fonte - Figura adaptada de Bacellar (2006. p. 4).

O organograma das atividades da cadeia produtiva do açaí está configurado em layout circular, com a finalidade de visualizar a sequência das etapas. A sequencialidade na cadeia é um item preponderante para a qualidade da polpa do açaí, no quesito da perecibilidade do fruto.

Outro fator importante do layout circular é o desenho proporcionar um panorama geral das atividades da cadeia.

Este organograma será a base norteadora para a intervenção do design no sentido de apontar estudos realizados a respeito da cadeia do açaí assim como desenvolver alternativas para os problemas existentes, culminando em um estudo de modelo conceitual para a produção do açaí, que será realizado no capítulo 4.

Vale ressaltar que, tanto neste capítulo, quanto no próximo, constam um levantamento de iniciativas, práticas e melhorias para a cadeia produtiva do açaí. O levantamento considerou algumas soluções desenvolvidas e adotadas pelo estado do Pará, que podem sofrer adaptações para a realidade do estado do Amazonas. 


\subsection{1}

\section{Colheita do fruto do açaí}

A colheita do fruto do açaí deve ser realizada na época correta. No estado do Amazonas, a colheita vai de janeiro a agosto, podendo, todavia, ocorrer variações dos meses nos outros estados produtores de açaí. Logo após a colheita, a seleção entre os frutos sadios e os estragados deve ser realizada.

O fruto é constituído pela polpa, semente e fibras. Segundo ROGEZ (2000) apud Martins et al. (2009, p.4), a polpa corresponde a 15\%, e a semente e fibras, a $85 \%$ do fruto. Existe uma larga aplicação da polpa na indústria alimentícia, ou seja, a menor parte do fruto é utilizada em sua totalidade, ao passo que a maior parte, semente e fibras, não possui um manejo adequado.

O açaí se forma em cachos na palmeira. A extração dos cachos (Figura 29) abrange a escalada no estipe, auxiliada por um artefato denominado peconha, feito de fibras, amarrado aos pés do colhedor. Com a peconha nos pés e uma faca nas mãos do extrativista, os cachos são cortados da palmeira e colocados sobre o solo que, por sua vez, está forrado com uma manta de plástico. Em seguida, os cachos são debulhados das ráquilas manualmente.

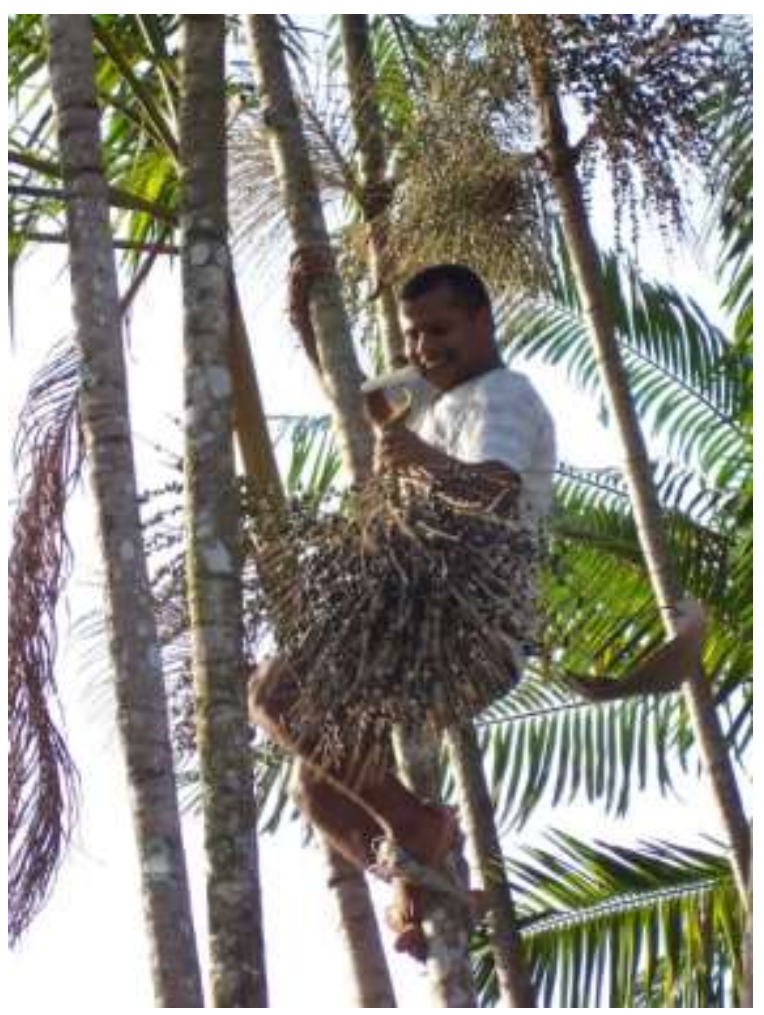

Figura 29 - Extração do cacho na palmeira. Fonte - http://3.bp.blogspot.com 
A colheita é realizada por escaladores jovens e meninos. De acordo com Homma (2006. p. 10), em Festivais de Açaí, uma disputa entre os escaladores para ver quem consegue retirar mais cachos em menor tempo faz parte das atividades. A habilidade dos escaladores é bem valorizada pela comunidade extrativista. Esta prática, apesar de ser perigosa, faz parte da tradição e da cultura do açaí.

A escalada nas palmeiras utilizando apenas a peconha (Figura 30a) aponta alguns riscos para o extrativista. Apesar de a peconha ser feita de fibra vegetal (Figura 30b) que possui uma resistência razoável capaz de suportar o peso do escalador, não garante a segurança do mesmo. Existe a possibilidade de estas fibras se romperem e causarem acidentes graves. Neste caso, o extrativista está desprovido de equipamentos que evitem acidentes, como por exemplo, cordas de segurança presas em seu corpo.
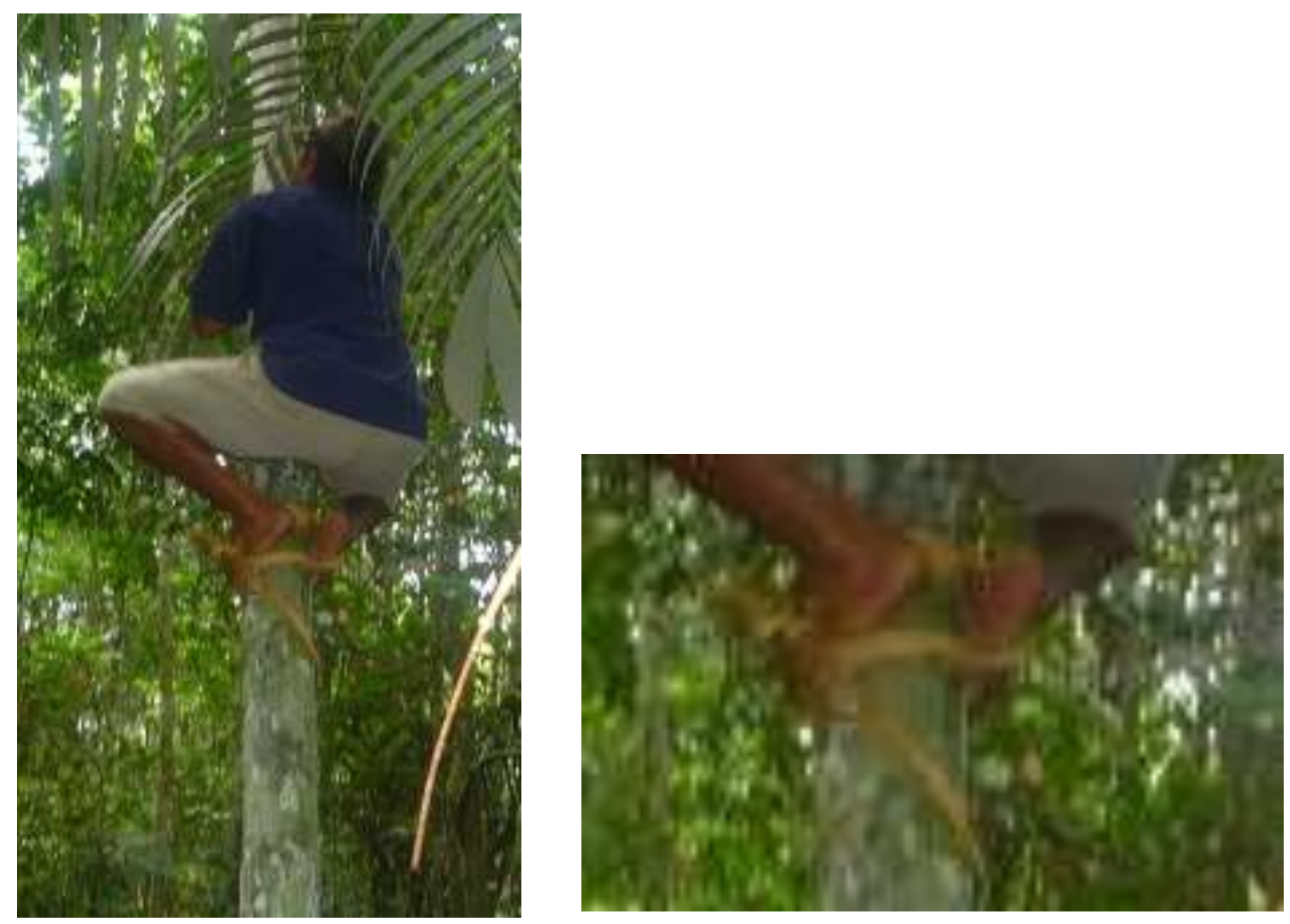

Figuras 30a e 30b - (a) Retirada dos cachos de açaí com uso da peconha e (b) Detalhe da peconha. Fonte - http://fas-amazonas.org/2010/08/fas-lanca-projeto-de-desenvolvimento-de-turismocomunitario-no-amazonas

Conforme a descrição da escalada nas palmeiras que medem de 12 a 20 metros de altura, apenas com o emprego da peconha e uma faca no cós da 
bermuda, sem Equipamento de Proteção Individual $(E P I)^{3}$, a escalada é considerada de alto risco.

$\mathrm{Na}$ escalada das palmeiras, são frequentes os comentários dos coletores sobre ferroadas de formigas e arranhões no corpo. Um outro relato é sobre a dificuldade de detectar o amadurecimento dos frutos, antes da subida na palmeira, quando ainda estão no solo. Esta dificuldade é causada por dois fatores. Existe uma distância visual, entre o coletor e os cachos de, aproximadamente, 10 metros, devido à altura das palmeiras que variam entre $12 \mathrm{~m}$ a $20 \mathrm{~m}$. Esta distância é um grande empecilho para determinar se o fruto está maduro. Outro impedimento é a questão da baixa luminosidade na floresta, onde as copas das árvores são grandes encobrindo uma parte dos frutos, dificultando a visibilidade destes, e também pela sombra feita pelas copas das árvores, que atrapalha a determinação do amadurecimento do açaí.

Esta observação da escalada na palmeira sugere uma boa situação para a intervenção do design sustentável, considerando que a peconha é um elemento que faz parte da tradição e da cultura entre as comunidades extrativistas do açaí, mas é um artefato inseguro.

\subsection{2}

\section{Debulhamento}

O debulhamento compreende a retirada manual dos frutos das ráquilas, uma tarefa onerosa e rústica para as mãos do coletor.

Os cachos são retirados das palmeiras e colocados sobre o solo, que se encontra coberto por uma manta de plástico (Figura 31). Este procedimento de forrar o terreno faz parte do processo de debulhamento, evitando-se a contaminação do fruto com o próprio solo, com insetos, com pedras e com galhos, entre outros elementos que se encontram na superfície do solo onde está o açaizeiro. A colocação de uma manta no local de debulhamento, também, facilita a seleção dos frutos sadios e dos estragados, assim como auxilia no recolhimento dos frutos que caem no entorno.

\footnotetext{
${ }^{3}$ Equipamento de Proteção Individual (EPI) são instrumentos utilizados por pessoas em situações de eventuais riscos ameaçadores à saúde ou à segurança durante atividades de lazer, atividades esportivas e o exercício da profissão.
} 


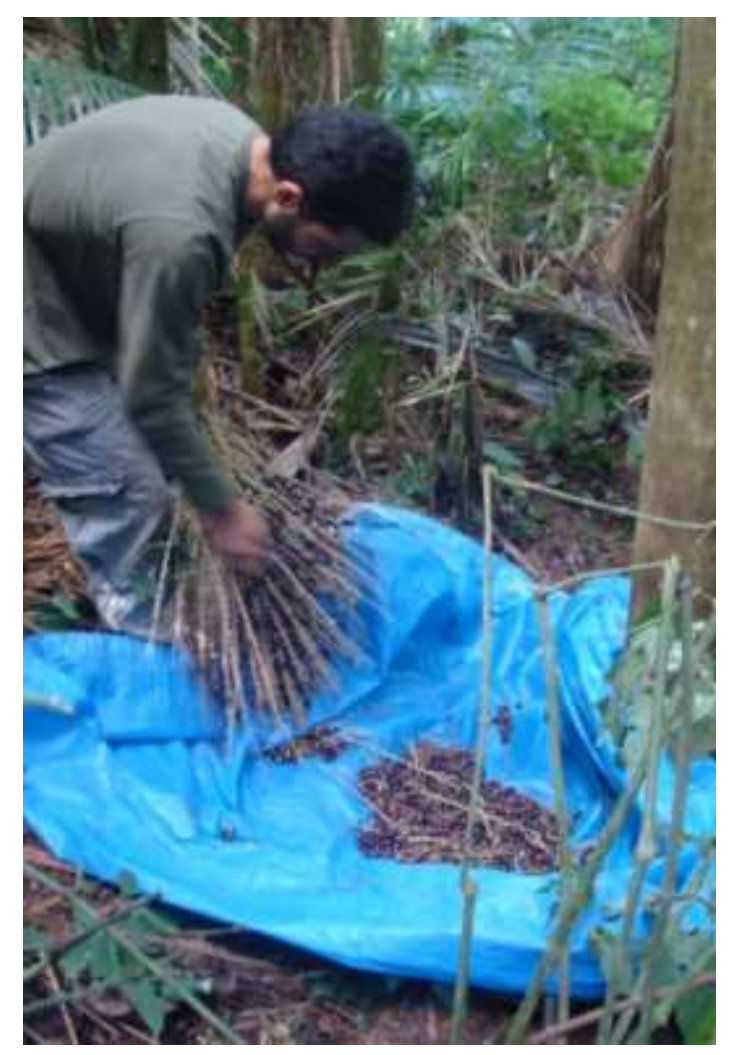

Figura 31 - Debulhamento manual sobre a manta de plástico.

Fonte - http://1.bp.blogspot.com

A manta sobre o terreno atende a uma das medidas para o controle de higiene, assim como previne e detecta a presença do inseto triatomíneos, conhecido por barbeiro. A manta na cor azul permite um contraste com a cor do inseto que, na maioria das espécies, é encontrado na cor preta. Tal inseto é o maior responsável pela transmissão da doença de Chagas ${ }^{4}$.

Esta atividade, assim como a colheita do açaí, é exercida sem o emprego de EPI. O debulhamento, remoção dos frutos nas ráquilas, é considerado uma tarefa lenta e abrasiva para as mãos do coletor. Para evitar este transtorno, é indicado o uso de luvas. Todavia, o uso de luvas pelos coletores não tem boa adesão por várias questões, sendo uma delas a perda de sensibilidade nas mãos, dificultando o trabalho e não solucionando efetivamente o problema. Uma intervenção de design nesta etapa do processo precisaria ser revista cautelosamente no Capítulo 5.

\footnotetext{
${ }^{4}$ A Doença de Chagas é uma doença tropical parasitária, conhecida também como mal de Chagas ou tripanossomíase americana, transmitida ao homem pelo trypanossoma cruzi, vulgarmente chamado barbeiro. A doença foi descoberta em 1909, pelo médico sanitarista Carlos Justianiano Ribeiro das Chagas.
} 


\subsection{3}

\section{Acondicionamento}

Logo após a colheita e o debulhamento, os frutos são acondicionados e transportados de imediato, ainda em estado in natura. Estes frutos seguem para os centros produtores e consumidores preferencialmente durante o período matutino. O processo deve ser realizado durante este turno devido à temperatura amena, favorecendo, assim, a conservação do fruto.

Os frutos são acondicionados em rasas (cestos ou paneiros) feitos com fibras vegetais (Figura 32), que proporcionam boa aeração para a conservação dos frutos. Os cestos suportam a capacidade de 14 até $28 \mathrm{~kg}$ de frutos, que também podem ser acondicionados em caixas de plástico ou basquetas (Figura 33).

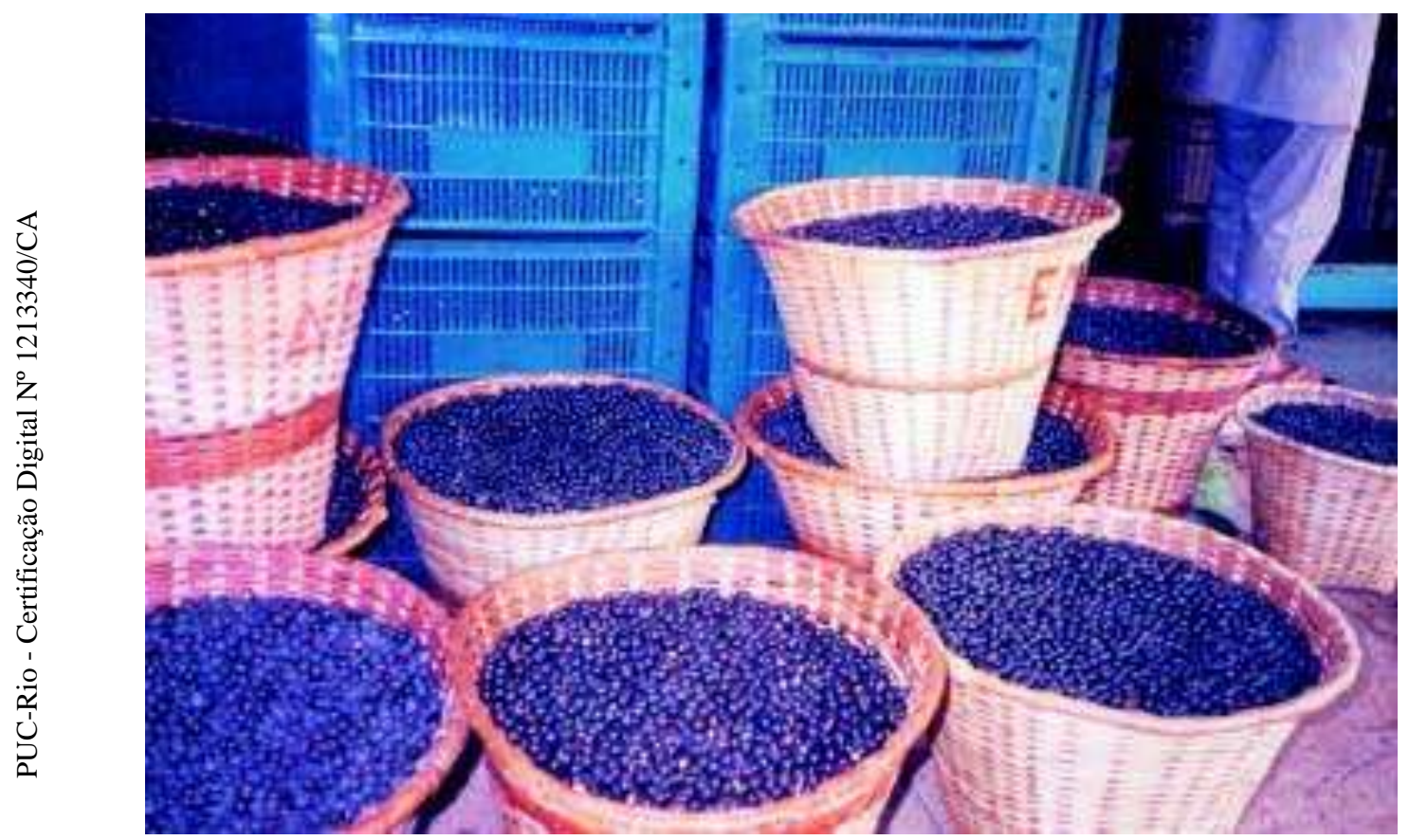

Figura 32 - Acondicionamento do fruto em cestos e caixas de plástico. Fonte - Embrapa Amazônia Oriental, Vasconcelos (2006).

As caixas de plástico (Figura 33) ou basquetas possuem uma durabilidade superior à das rasas. Entretanto, o formato retangular das caixas desfavorece a acomodação nas embarcações. As caixas de plástico se acomodam melhor no transporte rodoviário (Figura 34). 


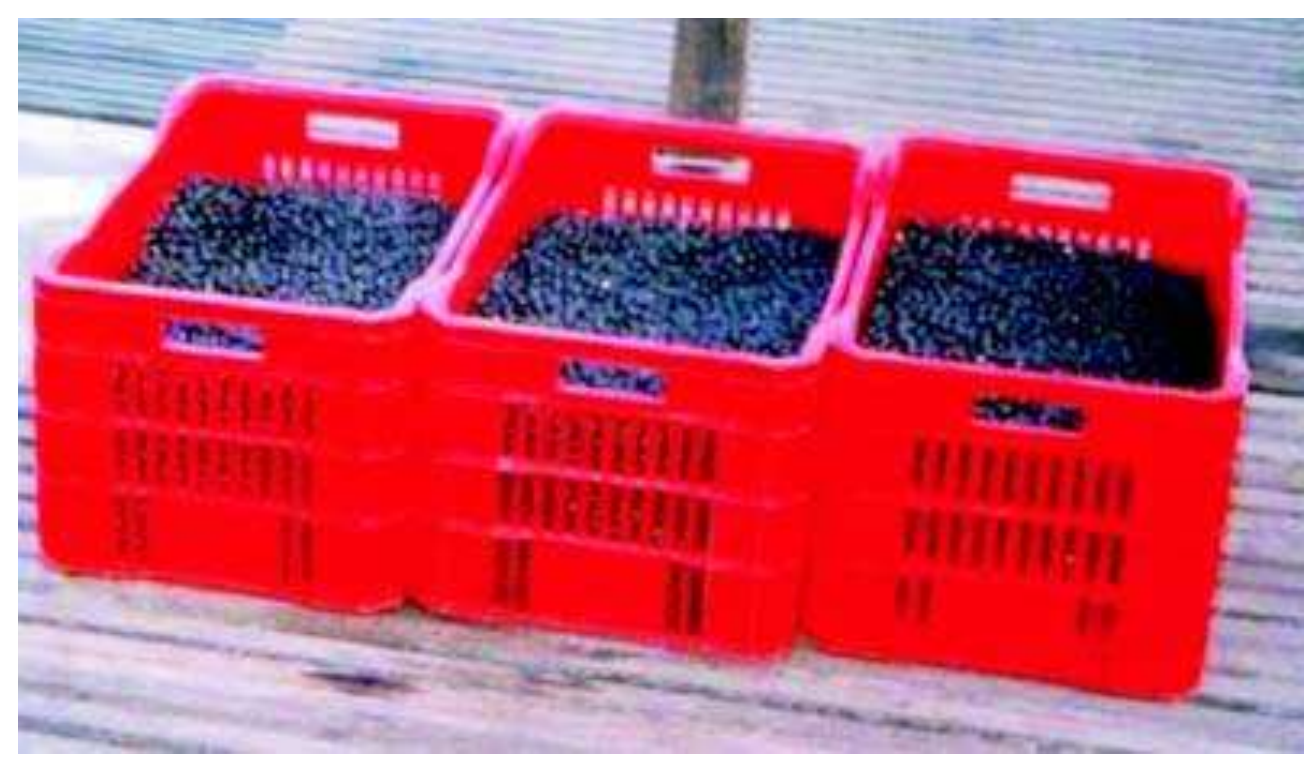

Figura 33 - Caixas de plástico.

Fonte - www.flickr.com/photos/geraldozayit/384679628

No manuseio, deve-se evitar que os frutos sejam transferidos das rasas, pois as trocas os machucam prejudicando a qualidade da polpa. Os frutos que são remanejados várias vezes das rasas são chamados de "surrados". Outra precaução a ser observada refere-se ao tempo entre a colheita e o consumo. $O$ período deve ser breve, do contrário, os frutos começam a secar e ficam estragados, impróprios para o consumo. É importante também protegê-los de chuvas, para impedir a umidade, evitando que atinjam o estágio de fermentação.

O acondicionamento dos frutos do açaí requer precauções específicas e agilidade, uma vez que a qualidade da polpa está atrelada a um acondicionamento cuidadoso. Além disso, tais procedimentos auxiliam na logística do transporte.

Conforme Homma (2006. p.6), a rasa é produzida com talos de arumã e feita por moradores locais e a sua utilização é para apenas uma safra, sendo descartada posteriormente. A rasa consiste em uma criação autóctone, existe e possui relevância para a cultura nativa, além de exercer a função de um objeto utilitário. A rasa empreende um valor simbólico e um valor funcional.

As rasas são preenchidas com o fruto do açaí e colocadas nas embarcações (Figura 34) para serem transportadas para os locais de processamento da polpa. Neste sentido, a flexibilidade dos talos de arumã e o formato cônico das rasas favorecem o arranjo espacial das embarcações que, por sua vez, possuem formas curvas. Outra vantagem, quando vazias, as rasas são empilhadas uma dentro da outra reduzindo o espaço no interior das embarcações. 


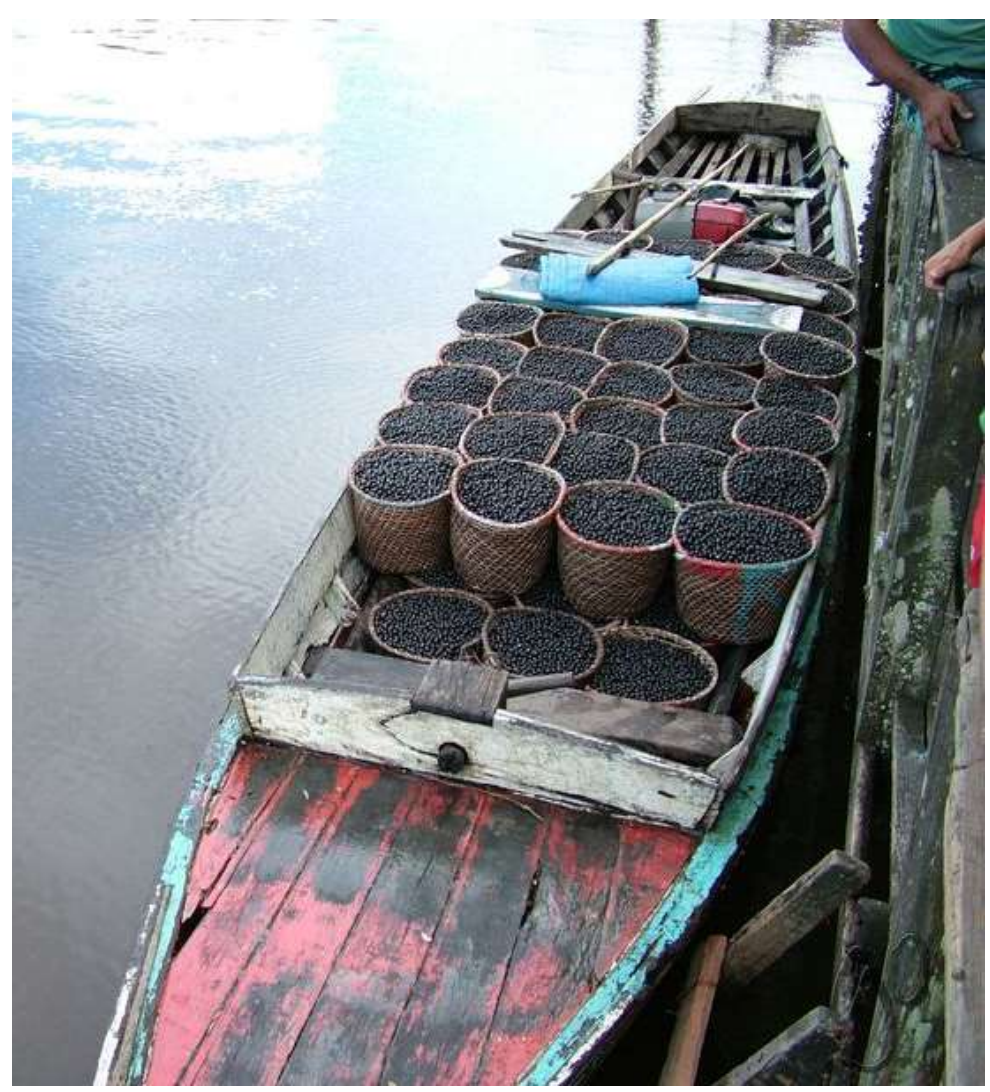

Figura 34 - Rasas colocadas nos barcos.

Fonte - www.flickr.com/photos/geraldozayit/3846796287/

\subsection{4}

\section{Transporte}

O escoamento dos frutos do açaí nas áreas de várzea da região amazônica é feito principalmente pelo meio de transporte fluvial. Já, nas áreas de terra firme, o transporte passa a ser o rodoviário.

Os frutos do açaizeiro são muito perecíveis e, por esse motivo, devem ser despolpados logo após a colheita e o debulhamento, não devendo esse período ultrapassar o tempo de 24 horas. Em situações em que esse tempo seja superior a 24 horas, os frutos devem ser transportados em sacos de polipropileno, com capacidade para $60 \mathrm{~kg}$, e encobertos com gelo. Todavia, o contato direto do gelo com os frutos deve ser evitado para impedir queimaduras no açaí e não comprometer a qualidade, e tampouco torná-los vulneráveis ao contágio de microorganismos.

Os frutos são acondicionados em cestos (paneiros ou rasas) em seguida dispostos nos barcos de pequeno ou médio porte para serem levados aos centros 
consumidores (Figura 35). Este transbordo exige um grande esforço físico humano; muitas vezes, o açaizal está localizado em uma área afastada da margem do rio que é a via de escoamento mais comum, a fluvial. Desse modo, o carregamento dos cestos ou sacas de açaí é feito no dorso do agricultor até as embarcações.

\subsection{5}

\section{Despolpamento}

Como foi dito anteriormente, os frutos do açaizeiro são bastante perecíveis. Devido a essa característica, o processo de despolpamento deve ser feito imediatamente após o debulhamento dos cachos. A morosidade deste processo inviabiliza o consumo da polpa em condições salutares.

No despolpamento, os frutos são submetidos, inicialmente, a um processo de maceração, ou seja, são imersos em água potável, aproximadamente por duas horas, para facilitar a separação entre polpa e semente. Após esse período, o fruto é colocado em uma máquina despolpadeira, empregada para a extração da polpa. A despolpadeira de açaí pode ser semi-industrial (Figura 35) ou industrial (Figura 36).

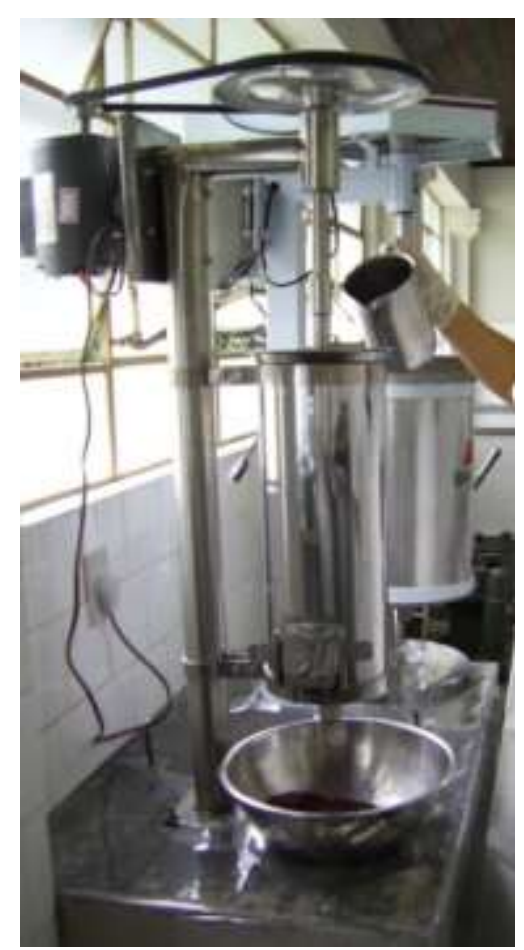

Figura 35 - Despolpadeira de açaí semi-industrial. Fonte - http://www.agencia.cnptia.embrapa.br (Foto: Rafaella Mattietto) 


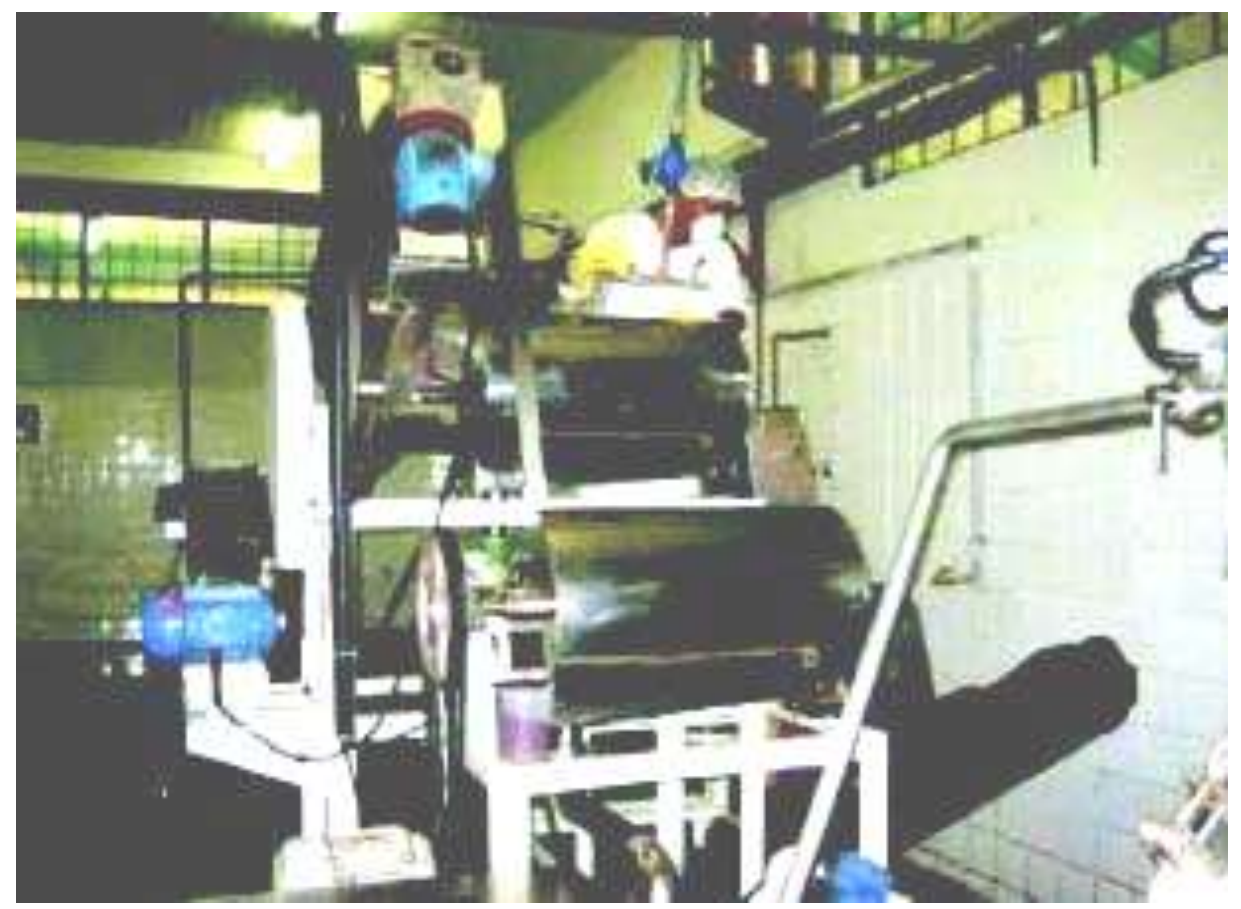

Figura 36 - Despolpadeira de açaí industrial.

Fonte - POEMA / UFPA (2006).

\subsection{6}

\section{Consumo}

O consumo do açaí é um hábito, principalmente na região Norte do Brasil, e vem conquistando gerações a ponto de tornar-se um elemento cultural reconhecido nacionalmente.

O fruto do açaí fornece uma bebida conhecida por vinho de açaí e seu despolpamento deve ser seguido à colheita e consumido logo após o beneficiamento da polpa. Para um consumo posterior, recomenda-se conservar a polpa gelada. O período entre a colheita e o consumo deve ser breve, do contrário, os frutos começam a secar comprometendo a qualidade do vinho e o rendimento da polpa.

Com o advento da industrialização no sistema produtivo do açaí, o método de, resfriamento e congelamento da polpa foi inserido. A pasteurização consiste em um tratamento térmico que submete a polpa do açaí à temperatura de $85^{\circ} \mathrm{C}$ durante trinta segundos. As vantagens desse método vão além da preservação do fruto, pois, também, elimina-se a possibilidade de contaminação pelo Trypanossoma cruzi, inseto responsável pela doença de Chagas. Tal doença já foi motivo para a redução no consumo do açaí, quando houve suspeita de contaminação. O inseto 
não resiste à temperatura empregada na pasteurização, garantindo o consumo do açaí sem perdas significativas dos antioxidantes e sem perdas também no sabor.

\subsection{7}

\section{Descarte}

Após o despolpamento, uma parte das sementes tem sido aproveitada para artesanato, ração animal e adubo, e a outra parte tem sido descartada.

O descarte das sementes do açaí é feito no aterro público de resíduos sólidos, denominado Aterro Controlado de Manaus - ACM, localizado no quilômetro 19 da rodovia AM - 010 (Manaus - Itacoatiara).

O ACM é considerado um aterro controlado que, segundo A Crítica ${ }^{5}$ (06 de abril de 2012), é um projeto específico de aterro com valas forradas de mantas, captação de gases, sistema de drenagem de chorume (líquido poluente), entre outras técnicas específicas.

O Aterro Controlado de Manaus - ACM existe há mais de vinte anos. Atualmente, o seu funcionamento obedece à licença Municipal de Operação - LMO, com o propósito de controlar a emissão de poluentes, manter a qualidade da água dos recursos hídricos e diminuir a poluição no meio ambiente. Esta licença é conferida pela Secretaria Municipal de Meio Ambiente e Sustentabilidade (SEMMAS).

Como foi dito anteriormente, algumas atividades do modelo produtivo do açaí demandam sequencialidade devido à perecibilidade do fruto e à característica recalcitrante da semente. Tais propriedades influenciam também no descarte, pois, para o melhor aproveitamento da semente destinada ao plantio, ela não deve ser estocada ou armazenada, mas, sim, plantada logo após o despolpamento.

Neste sentido, a cadeia produtiva segue uma sequência que apresenta dois grupos de sementes descartadas: sementes germinativas empregadas para o plantio e sementes não germinativas, que são estocadas e aproveitadas para diversos fins, como por exemplo, para o artesanato, para geração de energia elétrica, para ração animal, pavimentação de calçadas, produção de painéis e como substrato orgânico (Figura 37).

\footnotetext{
${ }^{5}$ A Crítica é um jornal diário da cidade de Manaus que aborda assuntos diversos, um meio de comunicação impresso e virtual.
} 


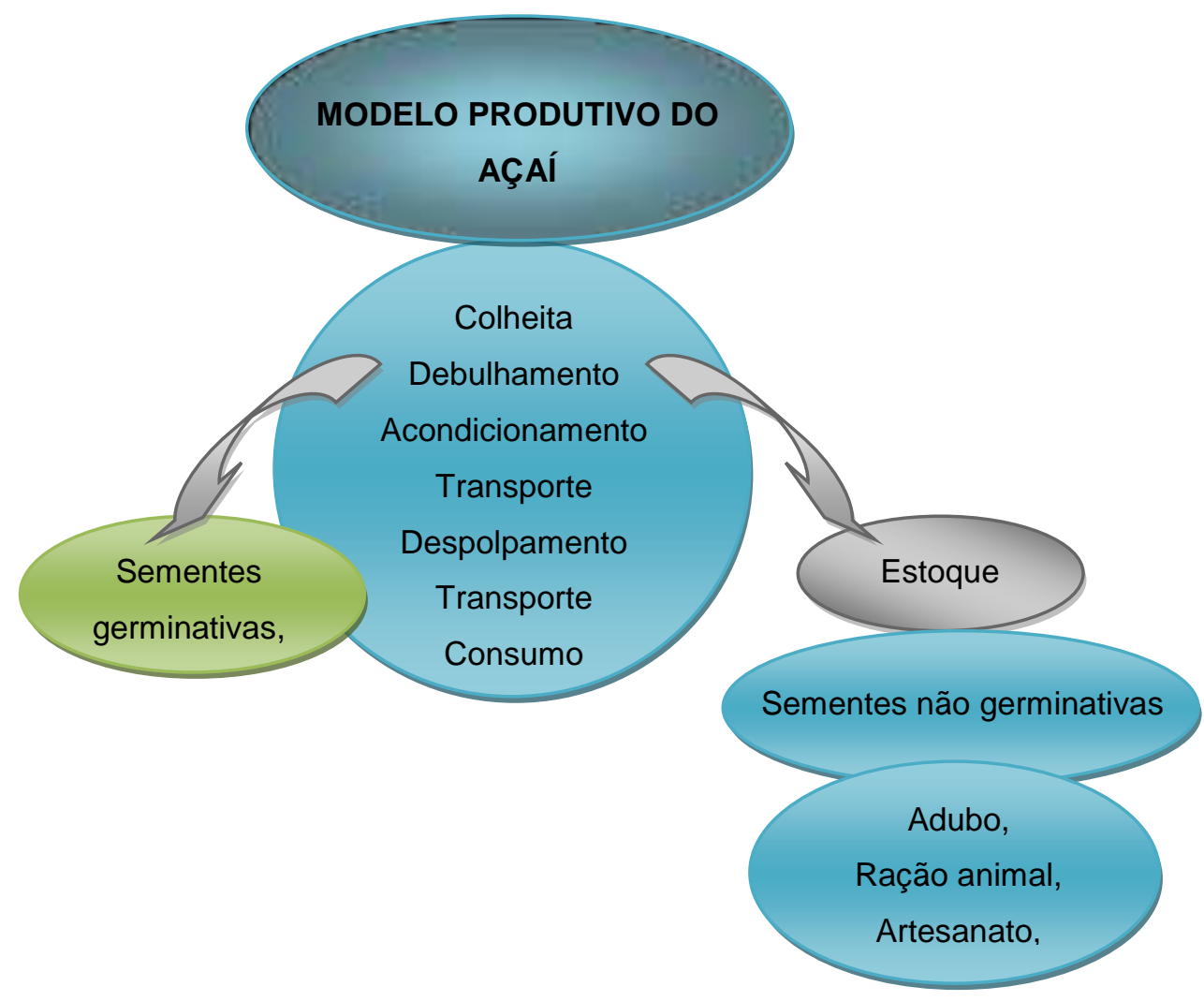

Figura 37 - Modelo produtivo do açaí com o aproveitamento dos resíduos.

O descarte compreende portanto dois grupos: sementes germinativas e sementes não germinativas. Nesta tese nos concentramos no estudo das sementes não germinativas como alternativa para a construção de calçadas e para a produção de painéis que serão discutidas no capítulo 5.

O item seguinte trata de dois estudos de campo com a finalidade de aproximar na pesquisa a teoria da práxis.

\section{5}

\section{Pesquisa de campo em Iranduba e em Codajás - municípios do Amazonas}

Foram realizadas duas pesquisas de campo, a primeira no plantio manejado de açaí localizado no município de Iranduba, e a segunda no Município de Codajás, onde existem uma Cooperativa de Açaí e vários plantios nativos e manejados situados nos arredores. 


\subsection{1}

\section{O açaí na Comunidade de Iranduba}

O levantamento do modelo produtivo do açaí em uma situação real foi planejado tendo em vista os benefícios que uma observação direta poderia trazer para o estudo.

O contato com o técnico Sr. Jolnei Selles, funcionário do Instituto de Desenvolvimento Agropecuário do Estado do Amazonas - IDAM, possibilitou a identificação da Comunidade Iranduba e o planejamento de um levantamento realizado com sua assessoria técnica.

Segundo as informações constantes no endereço eletrônico do $\operatorname{IDAM}^{6}$, o município de Iranduba fica localizado na $7^{a}$ Sub-Região, Região do Rio Negro (Solimões). Sua área territorial corresponde a $2.204 \mathrm{~km}^{2}$ e faz limites com os municípios de Careiro, Manaquiri, Novo Airão e Manacapuru (Figura 38).

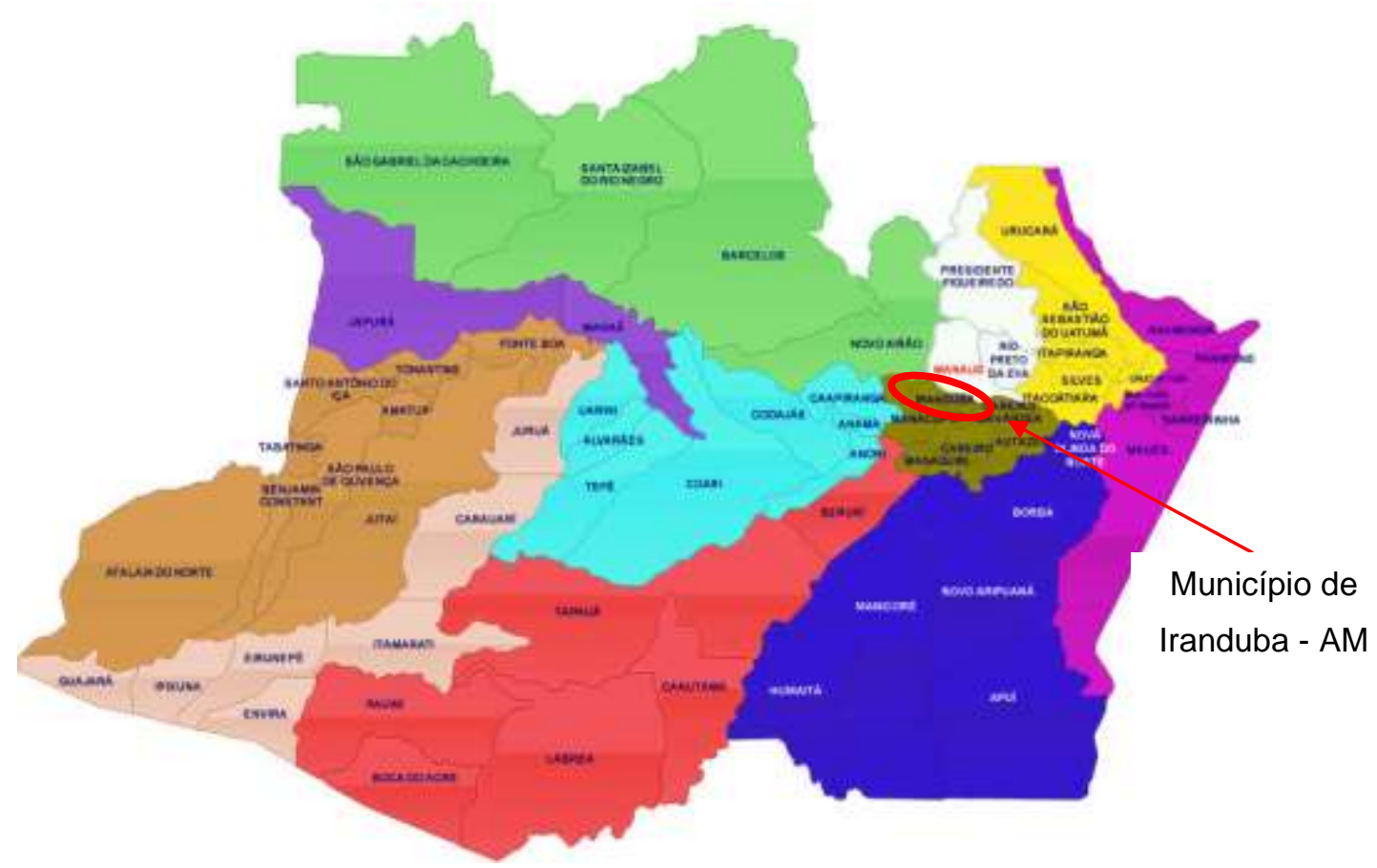

Figura 38 - Município de Iranduba em destaque, circundado na cor vermelha.

Fonte - http://www.coisaspraver.com/2012/11/mapa-do-amazonas-para-imprimir-e.html

A distância de Iranduba a Manaus, seguindo em linha reta, é de $25 \mathrm{~km}$ que, em via fluvial, são percorridos em duas horas. Os principais rios no percurso são o rio Solimões e o rio Negro. O clima tropical é chuvoso e úmido, a

\footnotetext{
${ }^{6}$ www.idam.am.gov.br, (acesso em 02 de abril de 2014)
} 
temperatura máxima é de $30^{\circ} \mathrm{C}$ e a mínima é de $27^{\circ} \mathrm{C}$, e os povos indígenas que vivem na região são das tribos Mura e Apurinã.

Ainda conforme o IDAM, na região existem 78 (setenta e oito) comunidades que contabilizam uma população urbana de 12.026 habitantes e uma população rural de 20.843 habitantes. A região dispõe apenas de transporte rodoviário e fluvial, não existindo a disponibilidade de transporte aéreo.

O município de Iranduba possui uma economia voltada para materiais de construção, encontrando-se nos arredores muitas olarias, pois Iranduba é um município com uma economia fortalecida pela produção e venda de tijolos e telhas. Além das olarias, existem, no município, não só agricultores, empresários, artesãos e moveleiros, mas também trabalhadores envolvidos nas atividades derivadas do cultivo e da coleta do açaí.

O Sr. Jolnei Selles, técnico do IDAM, é morador do município de Iranduba, agricultor orgânico, cuja especialidade é fruticultura. Ele foi o responsável pelo contato com o proprietário da fazenda e com outros agricultores que, generosamente, se propuseram a nos acompanhar a um plantio de açaí, nas proximidades do município.

A postura profissional do Sr. Jolnei é delimitada por preceitos da agricultura orgânica, que incide em sistema de produção que reúne técnicas específicas com modelos não convencionais, preservando a saúde do agricultor, assim como a do consumidor final do alimento que foi cultivado. Este método agrícola evita em sua prática o emprego de defensivos, pesticidas, fertilizantes, corretivos, dentre outros insumos agrícolas que combatem pragas.

O estudo de campo foi desenvolvido em uma fazenda localizada na zona rural de Iranduba, denominada Caldeirão, cuja ênfase está no plantio de hortaliças, legumes, frutas e criação de animais. O Sr. Jolnei nos acompanhou e nos apresentou ao agricultor Pedro e sua esposa e depois fomos encaminhados ao plantio de açaí (Figura 39). 


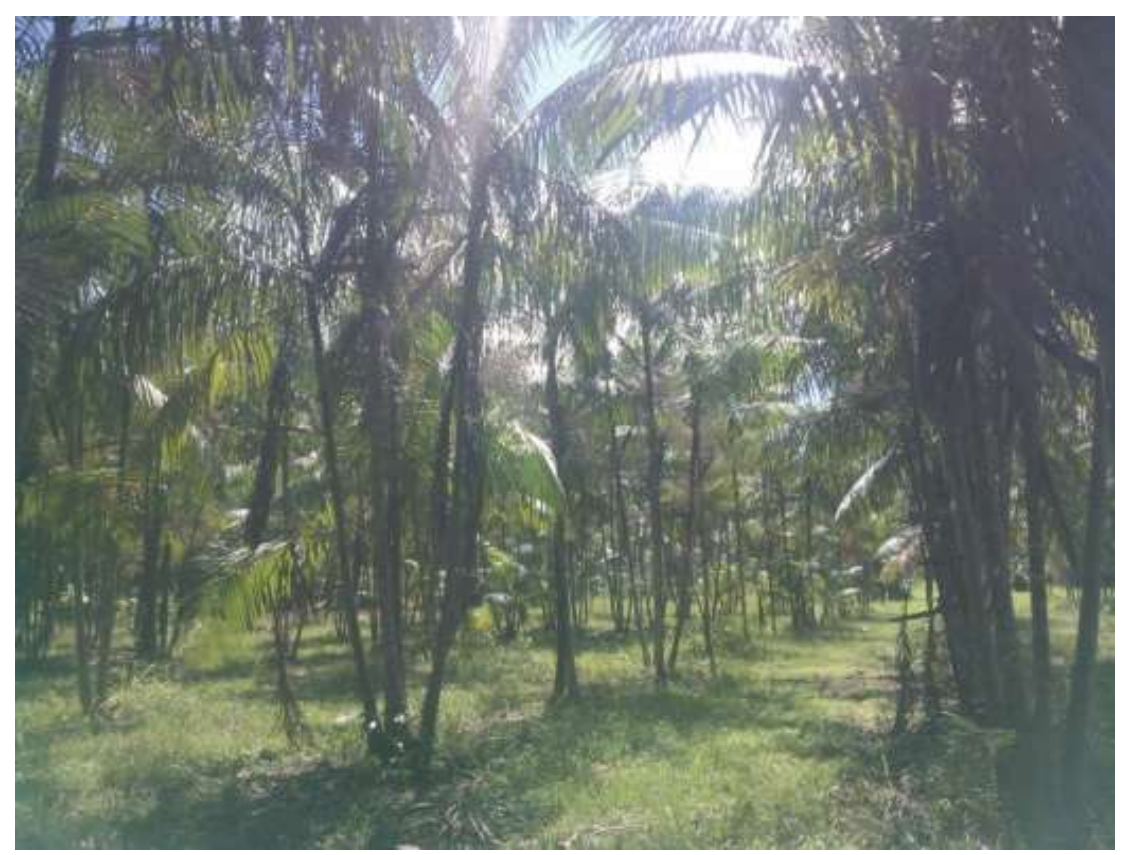

Figura 39 - Plantio de açaí.

Como foi mencionado anteriormente, o açaizeiro cresce até atingir em torno de $12 \mathrm{~m}$ (doze metros) de altura, podendo chegar a $20 \mathrm{~m}$ (vinte metros), e $14 \mathrm{~cm}$ (quatorze centímetros) de diâmetro.

Nesta fazenda, em específico, as palmeiras encontram-se jovens, com apenas dois a três anos de plantio, e isto implica que ainda não atingiram sua altura máxima de crescimento. Deste modo, é possível alcançar os cachos de açaí, dispensando o uso da peconha (artefato feito com fibra vegetal para auxiliar a escalada nas palmeiras).

Foram plantados, na fazenda de Iranduba, os dois tipos de estipes: palmeiras com um estipe e palmeiras touceiras.

O Sr. Jolnei comenta que, nos primeiros meses, o açaizeiro necessita de fósforo e, a partir do segundo ano, requer potássio, procedimentos que exigem uma atenção especial e cautela na quantidade dos nutrientes. Conforme o técnico do IDAM, no segundo ano de vida do açaizeiro, a palmeira passa por um "stress hídrico", ou seja, necessita de bastante água, mais ainda, se este período coincidir com os meses de pouca chuva, que correspondem a julho, agosto, setembro e outubro.

O Sr. Jolnei e o Sr. Pedro são favoráveis à prática da agricultura orgânica, então, valorizam todas as ações mitigadoras de impacto ambiental. Neste sentido, gostaram da proposta de aproveitamento das sementes para o cultivo do açaizeiro. 


\subsubsection{Comunidade e sustentabilidade}

Durante o levantamento do modelo produtivo do açaí na fazenda em Iranduba, em diálogos com o Sr. Jolnei, ele mencionou uma possível analogia econômica entre o extrativismo do palmito do açaizeiro com a venda de uma vaca. Ele apresentou as seguintes proposições: a venda de uma vaca, em curto prazo, é bastante lucrativa, porém com uma rentabilidade única, o que significa lucro apenas no momento da venda. Entretanto, com a retirada do leite da vaca, a médio e longo prazos, é possível se obter lucros constantes, bem menores do que com a venda da vaca, mas as vantagens são atribuídas ao lucro constante, o que propicia um rendimento estável para o proprietário da vaca.

Em relação à extração do palmito do açaizeiro, a lucratividade econômica possui uma dinâmica semelhante à da venda da vaca. Segundo o Sr. Jolnei, com a retirada do palmito, estimam-se bons lucros, no entanto, para a sua obtenção, é necessária a derrubada da palmeira, ou seja, a morte de uma planta que levou de um a dois anos para crescer, e na qual houve um investimento financeiro e um conjunto de ações para a manutenção do seu cultivo e crescimento. A derrubada da palmeira, por sua vez, mata a planta e compromete a biodiversidade de seu entorno. Sem a derrubada, a preservação do açaizeiro em pé significa manter o ecossistema harmonizado e proporcionar lucros a partir de seus frutos, gerando rentabilidade diária. Em síntese, a venda do palmito é rentável apenas na ocasião da sua comercialização, mas, após a negociação, o açaizeiro não poderá gerar renda, pois a palmeira é debelada após a extração do palmito.

A partir do relato do Sr. Jolnei, fica claro o seu posicionamento a respeito da lucratividade que os recursos naturais podem proporcionar aos agricultores e a importância de se ter uma equação cautelosa e equilibrada entre viabilidade econômica e responsabilidade ambiental.

A experiência do Sr. Jolnei como técnico agrícola, com vasto conhecimento na área, o torna um homem do campo com sensibilidade aliada ao conhecimento, permitindo o diálogo entre sua experiência de vida e sua atuação profissional. Diante disso, ele conclui que determinadas ações econômicas podem causar impacto na natureza. Sendo assim, muitas vezes, não compensa o impacto ambiental, valendo a pena preservar a natureza, pois ela resguardada é mais rentável do que os impulsos oferecidos pelo mercado. A partir desta concepção, ele consegue enxergar e prospectar o futuro da comunidade com base na sustentabilidade, e, neste conjunto, vem o respeito ambiental, social, cultural e econômico. 
O Sr. Jolnei sintetiza sua atividade profissional avaliando os benefícios entre a agricultura orgânica e a agricultura com agrotóxico, em escala industrial, com uma frase bastante conhecida popularmente: "Trabalho de formiguinha". A agricultura com agrotóxico consegue respostas rápidas para seu plantio, em detrimento dos malefícios ao meio ambiente devido à agressividade implementada pelo método.

A agricultura orgânica e a agricultura com agrotóxico são métodos distintos. A agricultura orgânica evita o uso intensivo de adubos químicos, pesticidas, máquinas agrícolas e irrigação. Vale reiterar a prática orgânica em favor da sustentabilidade. Neste sentido, o trabalho parece ser pequeno como uma formiguinha, mas o processo da agricultura orgânica conduz a resultados gigantes, ou seja, o desenvolvimento regional do agronegócio fundamentado nos princípios da preservação da floresta.

Vamos considerar, com base no comentário do Sr. Jolnei, não só uma formiga, mas também vários formigueiros trabalhando a favor da sustentabilidade. Sem dúvida, teremos um resultado eficiente que terá propagação e continuidade sistemática da produtividade, em harmonia com uma sociedade consciente.

Em síntese, a visita de campo realizada na comunidade de Iranduba proporcionou uma observação inserida no contexto empírico para o processo de obtenção e cultivo do açaí, apresentando indícios que podem elaborar cenários relacionados a um modelo conceitual para a produção do açaí na região.

Iranduba foi selecionado como município mais apropriado para a visita de campo, em razão da sua produtividade de açaí ser considerada entre as maiores do estado do Amazonas.

Anteriormente Codajás foi classificada como a maior produtora de açaí da região, contando com uma fábrica de beneficiamento do fruto, a Cooperativa de Açaí de Codajás. No entanto, havia indícios de que Codajás teria perdido este título e a Cooperativa sido extinta.

Acreditou-se, portanto, que Codajás teria pouca relevância para esta pesquisa, mas apesar disso um levantamento de campo no município e na Cooperativa foi agendado. Contrariamente a nossas expectativas, o município continua com uma grande produção de açaí e a Cooperativa não foi extinta, continua ativa, embora em condições precárias.

A partir desse levantamento de campo, o município de Codajás tornou-se nosso objeto de estudo, trazendo relevantes informações para este trabalho. Contudo, o estudo realizado em Iranduba foi também mantido na pesquisa. 
Isso porque no município de Iranduba foi observado um plantio com a inspeção da Embrapa, ao passo que em Codajás foi ressaltado um grupo de agricultores que tiveram 0 apoio do governo e hoje trabalham como cooperativados.

Iranduba e Codajás apresentam procedimentos diferentes em seus modelos produtivos que merecem atenção e enriquecem nossa visão sobre a produção de açaí. Neste sentido, as duas visitas de campo, Iranduba e Codajás, foram mantidas na pesquisa.

\subsection{2}

\section{Município de Codajás: interior do Amazonas}

O município de Codajás continua sendo o maior produtor de açaí do estado (Figura 40). Na intenção de aprofundar o entendimento de como funciona a dinâmica da cadeia produtiva do açaí, foi realizada uma visita aos plantios de Codajás como também à Cooperativa de Açaí de Codajás.

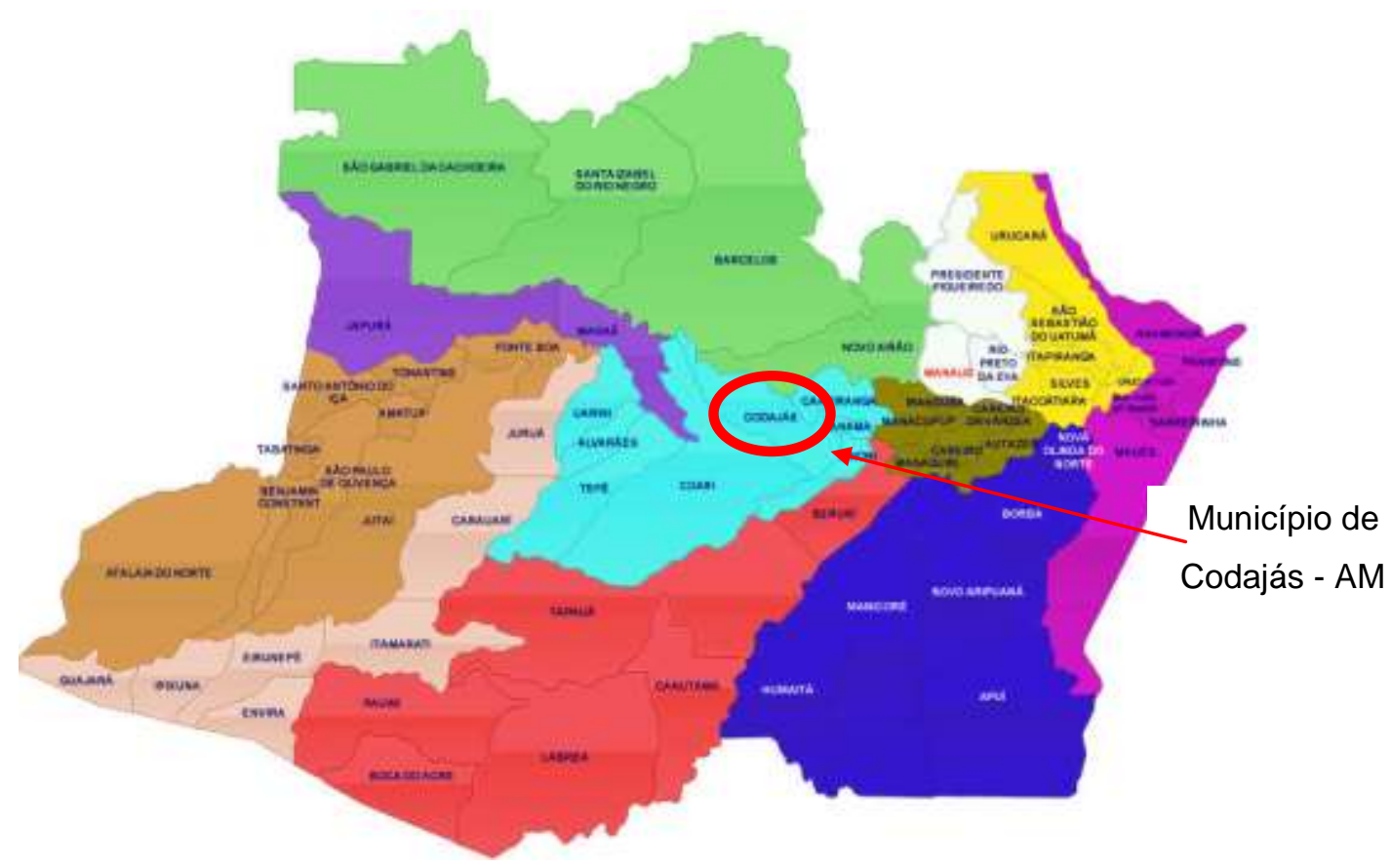

Figura 40 - Localização do município de Codajás no mapa do Amazonas.

Nogueira (2006) afirma que a produção de açaí no estado do Pará tem origem no extrativismo. Somente a partir da década de 1990 foi que a produção passou a ser obtida também de açaizais nativos manejados e de cultivos implantados em áreas de várzea e de terra firme. O autor esclarece que cerca de 
$80 \%$ da produção de frutos têm origem no extrativismo, e apenas os $20 \%$ restantes são provenientes desses açaizais manejados e cultivados em várzea e terra firme. Por isso a produção no estado do Amazonas se caracteriza por atividades realizadas em áreas dispersas, de modo diferente do modo como ocorre em outras áreas no país. Além disso, a safra do açaí no Amazonas compreende o período de janeiro até junho, ao passo que a safra no Pará ocorre de julho até dezembro.

Codajás, segundo o IDAM (Instituto de Desenvolvimento Agropecuário e Florestal Sustentável do Estado do Amazonas), está localizado na Região do Rio Negro - Solimões e faz limites com os seguintes municípios: Anamã, Anori, Coari, Barcelos, Novo Airão e Caapiranga. Possui uma área territorial que mede 18.905 $\mathrm{Km}^{2}$. A distância da sua sede municipal para Manaus compreende $240 \mathrm{~km}$ (em linha reta), e 290 km por via fluvial. Contudo o único acesso a Codajás é por via fluvial.

Conforme dados do IBGE (Instituto Brasileiro de Geografia e Estatística), de 2010, a população urbana de Codajás contabilizava 15.806 habitantes, já a população rural era composta por 7.400 habitantes. Em 2014, a população total estimada pelo IBGE para Codajás era de 26.242 habitantes.

O município de Codajás é formado por quatro grandes avenidas e várias ruas transversais (Figura 41). O ícone da cidade é representado por uma estátua de um extrativista de açaí (Figura 42). Na principal avenida, onde se encontra a feira livre e o comércio da cidade, há uma orla. Nesta orla, é possível se apreciar a beleza natural, o rio Solimões, o pôr do sol e a chegada das embarcações (Figura 43).

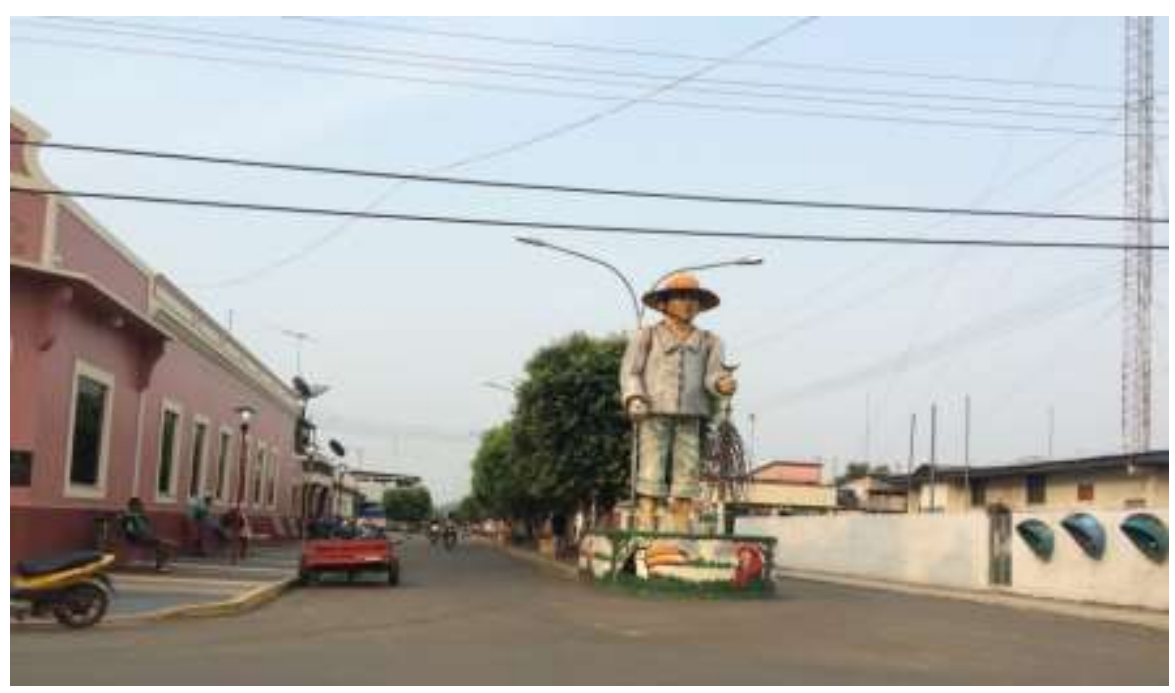

Figura 41 - Principal avenida do município de Codajás. 


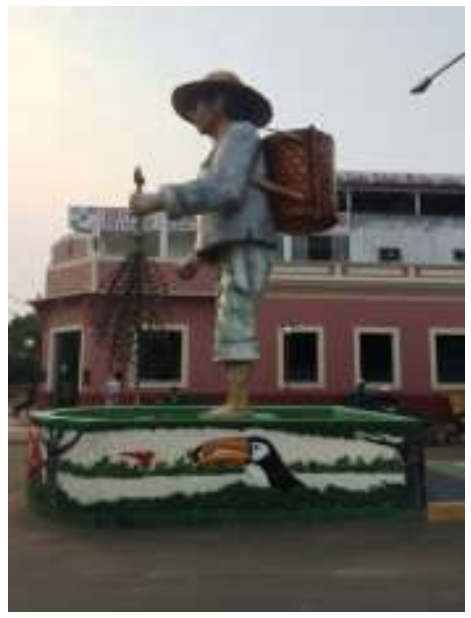

Figura 42 - O ícone de Codajás é representado por um extrativista de açaí.

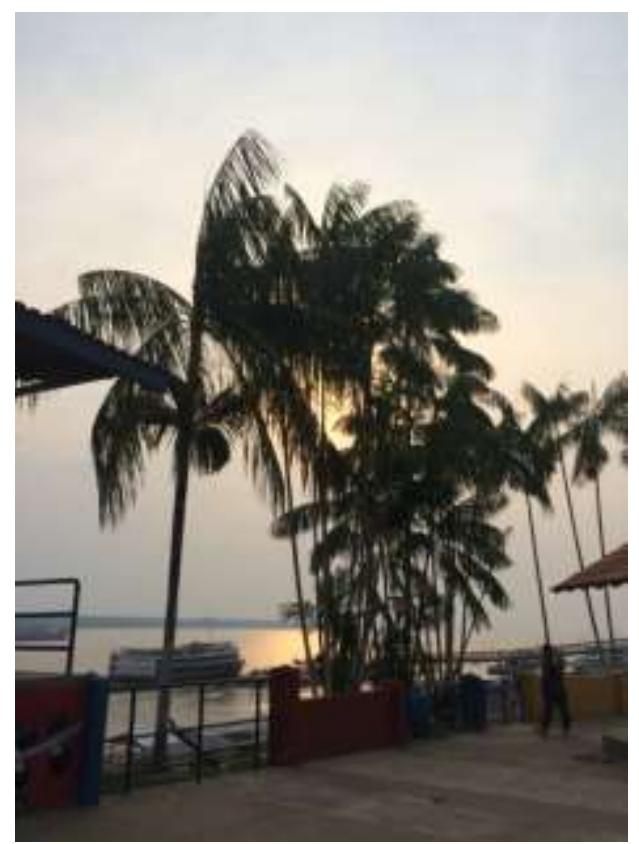

Figura 43 - Orla do município de Codajás.

O município conta com uma grande festa popular, a Festa Cultural do Açaí (Figura 44), que acontece no último final de semana do mês de abril. Esta festa é realizada no Centro Cultural que está localizado na orla de Codajás (Figura 45).

A programação da festa inclui vários concursos como o da Rainha do Açaí, o da melhor barraca decorada, o do artesanato e o de música e poesia. Este evento, na opinião da presidente da Cooperativa de Açaí de Codajás, a Sra. Franciani Sobreira da Silva, é responsável por um pequeno movimento econômico no município, 


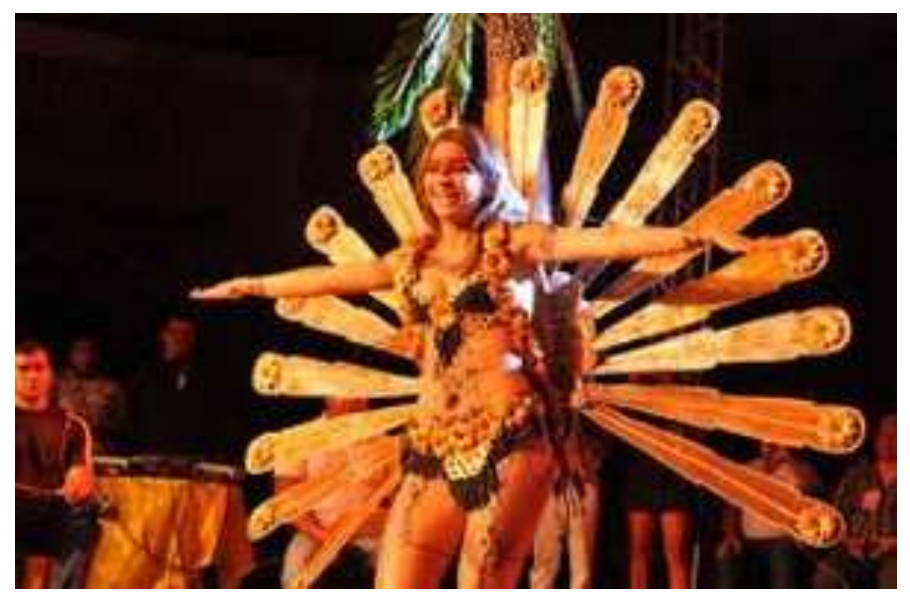

Figura 44 - Atração da Festa Cultural do Açaí.

Fonte - http://www.amazonianarede.com.br/26a-festa-do-acai-movimenta-a-cidade-de-codajas/

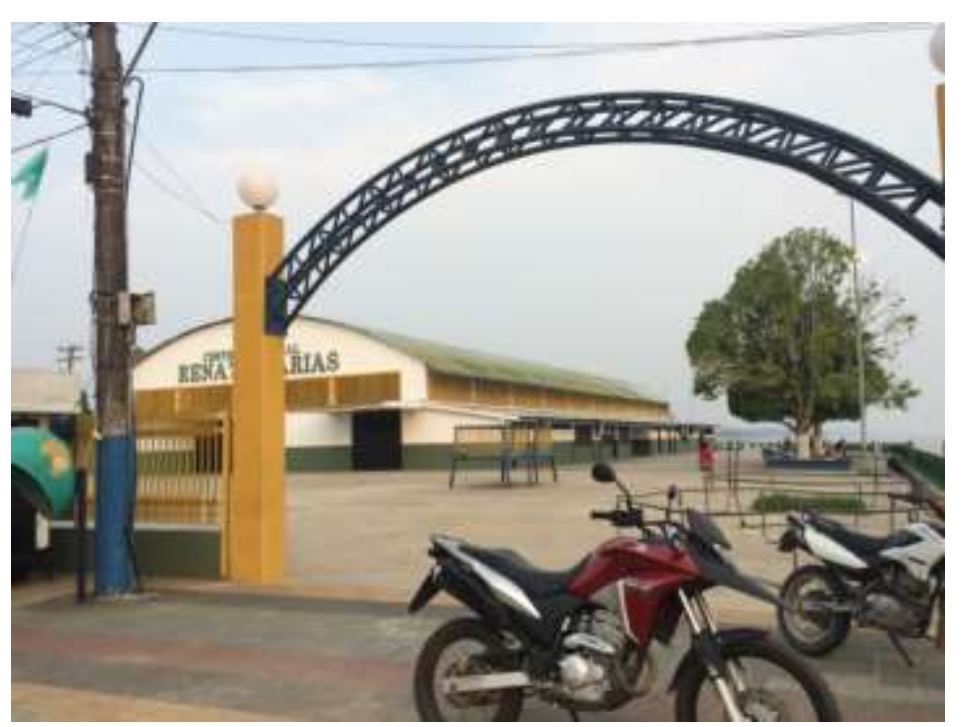

Figura 45 - Centro Cultural de Codajás, próximo à orla do município.

Segundo o Portal Amazônia ${ }^{7}$, a Festa do Açaí foi idealizada, no ano de 1987, por Adoniron Nelson Bastos Rodrigues, Sidney Hernani de Oliveira, Antônio Carlos Francisco Reis e outros da gestão do então prefeito Nathan da Silva Bastos. Foi oficializada pela prefeitura municipal de Codajás com a colaboração da EMATER/AM, em 1988, por um Decreto de Lei № 003/88.

Com o Decreto de Lei № 003/88 ficou definido que evento aconteceria nos finais de semana próximos aos feriados de 21 de abril e 01 de maio. Outra deliberação foi o estabelecimento de dois dias de feriado para as escolas municipais e um dia de feriado para os bancos. Atualmente, a festa representa

\footnotetext{
${ }^{7}$ Jornal virtual de informações sobre a Amazônia. http://www.portalamazonia.com.br/amazoniadeaz/interna.php?id=235 (acesso 15/10/2016)
} 
para Codajás a maior manifestação social e econômico-cultural, conforme o Secretário Municipal de Cultura, o Sr. Ebenézer de Alencar Bastos.

O Portal Amazônia afirma que a Festa atrai milhares de visitantes dos municípios vizinhos e da capital, durante os últimos três dias de abril. Neste período, ocorre uma programação diversificada, incluindo shows musicais com bandas locais, regionais e nacionais, realizados em palcos alternativos. Outros atrativos são a feira de artesanato, as gincanas, as atividades desportivas e culturais como torneio de pesca, os desfiles de beleza, e as exposições de artes plásticas e fotografias. No Centro Cultural ficam expostas peças de artesanato produzidas pelos artesãos da região com a matéria-prima do açaí. Ficam também expostos quadros que retratam a floresta, o fenômeno da piracema, e os 500 anos do Brasil, entre outros temas amazônicos e folclóricos.

Apresentações de danças regionais que abrangem o Balé da Palmeira e a Dança dos Açaianos também fazem parte da tradição festiva. As músicas e as poesias com a temática do açaí são apreciadas. A festa é finalizada com o desfile das candidatas ao título de Rainha do Açaí.

Segundo o Sr. Ebenézer, a Festa Cultural do Açaí é realizada pela Prefeitura Municipal de Codajás através da Secretaria Municipal de Cultura e conta com a participação direta das escolas das redes municipal e estadual. Os comunitários e as entidades locais também colaboram para a realização do evento.

A festa compreende momentos culturais, educacionais e sociais e viabiliza a venda de produtos agrícolas e produtos artesanais. Os momentos culturais acontecem por meio de concursos de poesias, músicas e danças. O ápice da festa, o momento mais esperado, é o concurso para o título de Rainha do Açaí.

Durante o período da festa são ministrados seminários e cursos a respeito do sistema produtivo do açaí. Na opinião do Sr. Ebenézer, os cursos são bastante interessantes para a comunidade, porém, seus efeitos e resultados são lentos e graduais. Neste ano de 2016, a Prefeitura Municipal promoveu o Seminário do Açaí em parceria com o Instituto de Desenvolvimento Agropecuário e Florestal Sustentável do Estado do Amazonas - IDAM e a Empresa Brasileira de Pesquisa Agropecuária - EMBRAPA. A finalidade deste Seminário foi promover a qualificação e equalização do sistema de produção, assim como a higienização e conservação do açaizeiro, ressaltando os princípios da sustentabilidade.

Os artigos comercializados no período da Festa Cultural do Açaí são produtos alimentícios e artesanais. Os produtos alimentícios abrangem a polpa de açaí, frutas, legumes, hortaliças, pescado e carne de sol. Os produtos artesanais, 
por sua vez, são objetos produzidos com os resíduos do açaizeiro, como por exemplo sementes, ráquilas, folhas, fibras e partes do tronco.

Estes produtos comercializados durante o período festivo, dinamizam a economia de Codajás, promovendo renda e geração de emprego. A festa que se repete anualmente, representa uma movimentação econômica para o município. Além de intensificar a economia, o evento difunde a cultura do açaí para outros estados e também na região, nas palavras do Sr. Ebenézer,

Para a realização anual da festa é necessário o apoio de órgãos municipais e estaduais. A parceria governamental é favorável, porém a comunidade deve estar consciente da possibilidade de realizar a festa acreditando no potencial empreendedor dos munícipes.

Entende-se, assim, que a intervenção financeira do governo é fundamental, mas não deve ser encarada como um fator determinante para a realização da festa. Este entendimento sugere o empoderamento político e social da comunidade e sua autonomia, prescindindo do governo. Essa autonomia é um posicionamento favorável para o povo de Codajás, que enfrenta graves problemas econômicos e sofre com a negligência das políticas públicas. É importante que os munícipes valorizem a atuação do governo e estabeleçam limites nesta atuação, para evitar a dependência do sistema.

Neste sentido, a Festa Cultural do Açaí representa esforços direcionados para a dinamização econômica, cultural, social, educacional e ambiental em Codajás, que por sua vez se apresentam como vetores de desenvolvimento para o sistema produtivo do açaí e para melhorias de qualidade de vida dos moradores da região. Desta forma, os esforços são válidos não apenas para Codajás, como também para os municípios vizinhos.

A opinião do Sr. Ebenézer, contudo, diverge do julgamento feito pela Sra. Franciani a respeito dos benefícios econômicos que a Festa do Açaí proporciona para Codajás. Segundo a Sra. Franciani, a festa é mais rentável para os comerciantes dos municípios vizinhos, que levam seus produtos para Codajás, vendem e retornam para seus municípios com o lucro. Esta economia gerada durante a festa acaba não circulando entre os comerciantes e moradores de Codajás.

A venda de produtos alimentícios, como por exemplo a carne de sol trazida por comerciantes vizinhos e comercializada em Codajás, é significativa, mas os comerciantes retornam para seus municípios com o lucro. Do mesmo modo, camisetas temáticas do evento, que são produzidas fora de Codajás e 
comercializadas durante a festa, geram um lucro que retorna junto com os comerciantes para seus municípios.

$\mathrm{Na}$ opinião da Sra. Franciani a festa resulta em uma pequena movimentação econômica, onde os maiores favorecidos são os comerciantes dos municípios vizinhos. Na apreciação do Sr. Ebenézer a efervescência econômica é favorável e unânime para todos os comerciantes oriundos ou não de Codajás.

Apesar das opiniões divergentes entre o Sr. Ebenézer e a Sra. Franciani, é certo que a festa traz benefícios econômicos para Codajás e adjacências. As divergências colocam em pauta quem são os maiores beneficiados com a economia gerada durante a festa.

Na minha opinião, contextualizada a partir da pesquisa de campo que me proporcionou um reconhecimento da realidade de Codajás, o cerne da questão não é identificar os beneficiados, mas sim acionar uma política econômica que favoreça todos os envolvidos: Codajás e municípios vizinhos.

Neste cenário, o maior problema é a ausência de uma estratégia econômica que possa identificar as fragilidades e desigualdades encontradas neste processo e apontar alternativas que oportunizem lucro para todos os comerciantes envolvidos. Neste tipo de situação a Economia Solidária se mostra adequada, atendendo melhor aos requisitos traçados. Este conceito de Economia Solidária é fluente para os moradores de Codajás que vivenciam práticas similares em seu cotidiano.

A Economia Solidária é um modelo econômico inovador que compreende a produção, o consumo e a distribuição de riqueza estimando lucros, mas priorizando o ser humano. Um modelo organizado para a autogestão que ressalta as práticas de produção de bens, comércio justo, finanças solidárias e prestação de serviços. As cooperativas, associações e redes de cooperação fazem parte deste conjunto da Economia Solidária. Este modelo econômico é expressivo no espaço público, colaborando para a formação de um ambiente socialmente justo e sustentável, empreendendo uma dimensão social, cultural, política e ambiental.

Neste sentido, não será difícil para Codajás adotar um modelo de Economia Solidária na oportunidade econômica proporcionada pela festa, visto que alguns segmentos no município já empregam estas práticas corriqueiramente. Acredito que um modelo de Economia Solidária auxiliará na identificação das fragilidades da situação e na busca de alternativas para minimizar as desigualdades econômicas entre os comerciantes de Codajás e os comerciantes vizinhos. 


\subsubsection{1}

\section{Levantamento da Cooperativa de Açaí de Codajás}

A pesquisa de campo teve início com um contato por telefone com a senhora Franciani Sobreira da Silva, presidente da Cooperativa de Açaí de Codajás. No contato foi marcado um encontro que se realizou no município. $O$ encontro começou com uma conversa informal entre nós e logo iniciamos uma entrevista, cujo roteiro e perguntas estão disponíveis no apêndice desta tese. Em seguida, a senhora Franciani nos levou para algumas visitas: uma visita rápida à cidade; em seguida uma visita à Cooperativa, e por fim, uma visita aos plantios de açaí.

A senhora Franciani exerce a função de presidente da cooperativa há um ano, e seu mandato irá expirar no próximo ano de 2017. O processo de ocupação desse cargo é por eleição. Um edital é lançado e a Assembleia dos Cooperativados vota. A senhora Franciani além de presidente é também uma cooperativada, pois possui uma propriedade, produz e vende sua produção de açaí para a Cooperativa.

A formação da Cooperativa de Açaí de Codajás deu-se no ano de 2002 quando os agricultores e extrativistas da região perceberam sua capacidade produtiva e recorreram ao poder público. No ano de 2004, a SUFRAMA (Superintendência da Zona Franca de Manaus), em parceria com a Prefeitura de Codajás e o governo do Amazonas, construiu uma fábrica de beneficiamento do açaí para o exercício das atividades da Cooperativa. Ainda como uma ação extensiva ao empreendimento, foi realizada uma obra de pavimentação no ramal de acesso a esta Cooperativa. No ano seguinte, ocorreu o início do funcionamento da fábrica com oitenta e seis cooperativados.

O novo empreendimento em Codajás modernizou o beneficiamento do fruto e dinamizou a realidade econômica do município. Nos primeiros anos da fundação da Cooperativa, houve uma grande produtividade, havendo até exportação para os Estados Unidos e Canadá nos anos de 2006 e 2007. A SUFRAMA entregou o prédio com uma estrutura física projetada para 0 beneficiamento do açaí que corresponde à seleção do fruto, à lavagem, ao despolpamento, à pasteurização, ao envase, ao congelamento e ao transporte. Além da estrutura física, foram doados equipamentos modernizados para a realização de todas as atividades, incluindo uma fábrica de gelo, um caminhão, um trilho motorizado, um contêiner refrigerado e uma balsa. Todo este empreendimento motivou a economia do açaí em Codajás, fazendo com que o 
município merecesse o título de maior produtor de açaí do estado do Amazonas. Entretanto, este período de animosidade econômica foi curto, devido a vários fatores, entre eles, dificuldades operacionais, administrativas e financeiras.

Hoje a cooperativa trabalha com máquinas que necessitam de manutenção, haja vista que algumas estão desativadas, assim como, o contêiner que também está inativo, necessitando de uma peça para que o motor volte a refrigerar. A balsa foi substituída por um barco, devido às más condições de navegação da mesma.

A gestão administrativa financeira da Cooperativa foi mantida pela delegação da SUFRAMA durante o período de 2004 até 2008. Segundo a senhora Franciani, esta gestão deixou a cooperativa com alguns problemas financeiros, e ainda sem a renovação do selo orgânico emitido pelo Ministério da Agricultura.

No ano de 2009, os cooperativados assumiram a gestão administrativa financeira da Cooperativa. Porém, em virtude da administração anterior e do acúmulo de problemas, aconteceram entraves na realização da comercialização da produção de açaí. Hoje, a Cooperativa tenta recuperar antigos clientes e conseguir novos compradores para o fruto do açaí, mas a senhora Franciani diz encontrar dificuldades para reverter esta situação, além da de falta de manutenção no prédio e nos equipamentos.

Atualmente, a senhora Franciani exerce o cargo de presidente da Cooperativa, sem remuneração, sendo responsável pela gestão administrativa e financeira da mesma. Fazem parte de suas atividades, o contato com e entre os cooperativados, reunião com o Ministério da Agricultura, reunião com a imprensa, conferência do produto, pagamento dos cooperativados, compra de embalagens, contato com o contador, limpeza geral e vigilância da Cooperativa.

Existe um desinteresse por parte dos cooperativados para assumirem atividades e responsabilidades para além do trabalho extrativista. Eles trabalham exclusivamente no período da safra. $\mathrm{Na}$ fala da senhora Franciani, ocorrem tarefas na entressafra, de ordem administrativa e financeira, que são da competência e responsabilidade dos cooperativados, mas eles se recusam a cumpri-las, se limitando apenas às atividades extrativistas. Houve um acordo interno a respeito da divisão de tarefas em que o vice-presidente fica responsável pelo gerenciamento do barco, e a presidente, Sra. Franciani, pela administração da Cooperativa.

A senhora Franciani afirma que a Cooperativa possui uma dívida na União e que trabalha em condições precárias, com registro de setenta e seis 
cooperativados com idade média entre sessenta e setenta anos, não conseguindo renovar este número de cooperativados. Atribui este fato ao interesse dos jovens por uma profissão menos árdua e uma evasão do campo para a cidade. Os jovens de Codajás acreditam e vislumbram que os grandes centros urbanos oferecem empregos mais leves e mais lucrativos.

No setor de beneficiamento do açaí (que acontece no interior da Cooperativa), os funcionários não são cooperativados, são terceirizados com idade média entre vinte a até trinta e cinco anos. Estes funcionários são contratados pela presidente da Cooperativa. Os cooperativados (extrativistas e agricultores) trabalham no campo, onde colhem, debulham, ensacam e depois transportam sua produção para vender na Cooperativa.

Logo após o debulhamento, os frutos devem ser comercializados, devido a sua característica perecível. Desse modo, os cooperativados seguem rapidamente para a Cooperativa.

A venda do fruto é realizada logo após a conferência do produto e o pagamento é feito à vista, sendo o valor estimado abaixo do mercado. Hoje, uma saca de cinquenta quilos de açaí equivale a sessenta e cinco reais no mercado. $A$ Cooperativa compra esta mesma saca por sessenta reais. Estes valores alteram conforme a safra e a entressafra, chegando a cento e trinta reais na entressafra.

Como já foi mencionado, a safra do açaí no estado do Amazonas coincide com a entressafra no estado do Pará. Esta periodicidade intercalada nas safras promove uma produção contínua durante o ano, porém apenas no Pará se consegue ter produção de açaí o ano inteiro, uma vez que o estado está melhor estruturado do que o estado do Amazonas e a Cooperativa de açaí de Codajás. Durante o período de janeiro até junho, uma empresa do Pará aluga alguns equipamentos e o espaço físico da Cooperativa em Codajás, e transporta para o município equipamentos, transferindo temporariamente sua fábrica. Desse modo, consegue produzir na entressafra e transportar a produção para o Pará, atendendo à demanda anual de açaí do estado. Por outro lado, a Cooperativa de Codajás tende a aceitar o preço cotado pela empresa do Pará, que é sempre valorado abaixo do mercado.

Outro problema é não possuir a mesma estrutura física e financeira para enfrentar a entressafra, e contornar o período de baixa produtividade. Desse modo, no período de entressafra as atividades ficam totalmente paralisadas no município de Codajás, tanto em relação às atividades realizadas no campo, que consistem da colheita e debulhamento do fruto, quanto às atividades realizadas na Cooperativa, que compreendem o beneficiamento do açaí, envase, 
comercialização e transporte. Neste sentido, a senhora Franciani assegura ser comprometedor e um problema grave para a Cooperativa o período de estagnação das atividades na entressafra.

Para a senhora Franciani, existe uma iminente ameaça que irá afetar diretamente as atividades comerciais da Cooperativa, que se trata da instalação de uma nova fábrica de beneficiamento de açaí no município de Codajás, com funcionamento previsto para o ano de 2016. O surgimento de um novo empreendimento no município aponta uma possível concorrência, que provoca um receio na senhora Franciani com relação à Cooperativa.

As dificuldades da Cooperativa de açaí de Codajás estão no âmbito de recursos materiais e se estendem para o âmbito de recursos humanos. Os cooperativados se ausentam das atividades na Cooperativa. A senhora Franciani é enfática com relação à falta de envolvimento dos cooperativados.

Do mesmo modo que o desinteresse dos cooperativados dificulta as atividades da Cooperativa, a falta de conhecimento relacionado ao cooperativismo também atrapalha. É necessário que os cooperativados percebam a relevância do trabalho coletivo.

Para minimizar este problema, o governo estadual possibilitou cursos de especialização, para quarenta e duas pessoas do Amazonas no estado do Paraná. A senhora Franciani, por exemplo, pôde realizar um mestrado em Administração de Negócios - MBA em Gestão de Cooperativa. Do mesmo modo, o governo juntamente com o SEBRAE (Serviço Brasileiro de Apoio às Micro e Pequenas Empresas) promoveram os seguintes cursos: Cooperativismo e Associativismo; Conselheiro Fiscal e Administrativo; Saber Empreender e Beneficiamento do Açaí.

Os cursos de conteúdo técnico são sempre bem-vindos, mas existe uma carência em cursos que ressaltem os valores da cidadania, do meio ambiente e de políticas públicas. É sabido que não basta ter realizado cursos e cumprir carga horária, é necessário colocar em prática os conhecimentos adquiridos e tornar-se um profissional crítico com desempenho proativo. A dinâmica participativa e interativa não faz parte da realidade de Codajás, a população é acomodada, como a de todo o estado do Amazonas. Ambos valorizam a inércia, desse modo, acomodam-se ao sistema político.

Existe uma cultura assistencialista no estado do Amazonas, em que, de modo inconsciente ou não, as pessoas preferem esperar as melhorias advindas por parte do governo, a ter iniciativa e mudar o seu cenário de estagnação econômica, social, educacional e cultural. 
Apesar, de todas as dificuldades, a Cooperativa de Açaí de Codajás produz de três a quatro mil toneladas de polpa por dia. Segundo a senhora Franciani, isto corresponde a um número de duzentas a duzentas e cinquenta sacas do fruto por dia.

Para a operacionalidade da Cooperativa, é necessário o registro de estabelecimento e o registro do produto emitido pelo Ministério da Agricultura, que classificou a polpa da Cooperativa de açaí de Codajás tipo "B". São três categorias de polpa conforme a consistência: tipo "A" incide em uma polpa mais densa; tipo "B" uma polpa intermediária e a tipo " $\mathrm{C}$ " é a polpa mais rala, conhecida como a polpa popular.

O trabalho no campo tem início às seis horas da manhã, antes desse horário a mata ainda está escura, e as atividades são finalizadas às dezessete e trinta. Aproximadamente, são coletados por pessoa, diariamente, de duas a três sacas de cinquenta quilos de açaí. Esta produção é considerada uma atividade lenta por dois motivos: o primeiro, pelo fato da pessoa ter de escalar várias vezes o açaizeiro; o segundo, pelo fato do debulhamento das ráquilas dos cachos ser feito de forma individual.

Na maioria das vezes, o extrativista só conclui que o açaí está maduro quando se aproxima do fruto. A maturação do fruto é duvidosa quando vista ainda do solo (abaixo da copa do açaizeiro), quando aparentemente o fruto parece estar maduro. Porém, quando visto de perto, o extrativista certifica-se de que o fruto não está pronto para a colheita. Isto implica subir várias vezes, em vários açaizeiros, até encontrar cachos devidamente maduros e prontos para a colheita.

O trabalho manual de debulhamento também demanda um tempo prolongado. $O$ extrativista retira os frutos das ráquilas separadamente, debulha uma ráquila a cada vez. Este movimento é repetido aproximadamente cento e cinquenta vezes por cacho, e este quantitativo significa o número de ráquilas existente em cada cacho, podendo ser repetido mil e quatrocentas vezes, caso sejam debulhados dez cachos por dia. O movimento repetido pode causar lesão e fadiga muscular, como também a formação de calos, fissuras e machucados nas mãos. Verifica-se também que a posição do corpo curvado, para a realização do debulhamento, é bastante cansativa e prejudicial à coluna vertebral. Com base nestas observações, conclui-se que o debulhamento é uma tarefa que demanda tempo, tornando a produtividade lenta além de insalubre para a saúde do extrativista.

Após o debulhamento, os frutos são colocados em sacos de plástico de cinquenta quilos (Figura 46) ou em basquetas (caixas de plástico) para serem 
transportados para a Cooperativa. No município de Codajás, o transporte mais empregado pelos moradores é a bicicleta e a motocicleta (Figura 47); para se adaptar a esta realidade, os extrativistas colocam os frutos em sacos de plástico de cinquenta quilos e os colocam no bagageiro das motos, para transporta-los da mata até a Cooperativa.

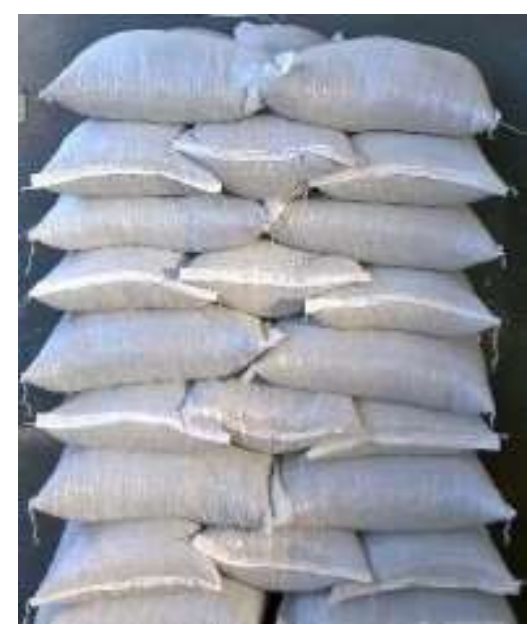

Figura 46 - Acondicionamento dos frutos em sacos de plástico de cinquenta quilos. Fonte: http://www.mfrural.com.br/mobile/ClassificadosAnuncio.aspx?id=1486

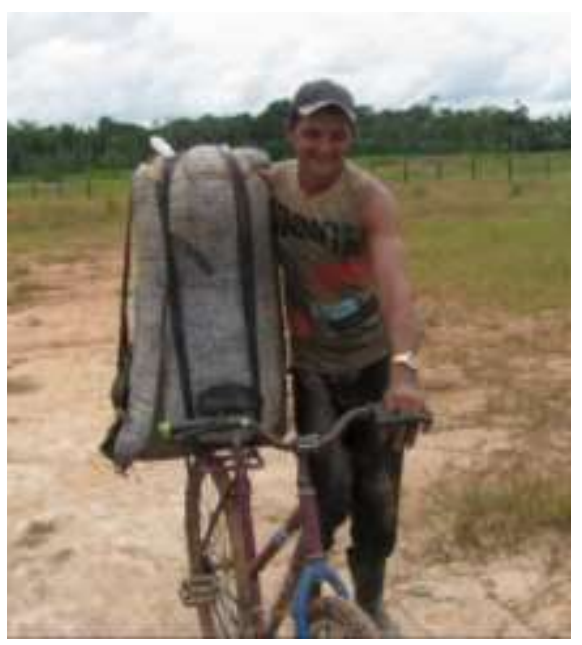

Figura 47 - Um dos transportes utilizados pelos moradores de Codajás é a bicicleta. Fonte: http://acrefeijonew.blogspot.com.br/2010/02/cultura-ja-comecou-venda-do-melhor-acai.html

Tanto a colheita do fruto, quanto o debulhamento são realizados de maneira tradicional: a colheita com a peçonha, e o debulhamento manual. Ambas atividades são realizadas desprovidas de equipamentos que agilizem e facilitem as respectivas tarefas, como também sem Equipamentos de Proteção Individual EPIs. As duas atividades são realizadas de maneira rústica e braçal, exigindo esforço físico do extrativista.

A Cooperativa de açaí de Codajás (prédio na cor amarela) agrega a fábrica de gelo (prédio menor na cor branca), como mostra a Figura 48. 
O muro da Cooperativa é destinado para a sua identidade visual, que por sua vez ainda não foi elaborada por falta de verba.

A pavimentação de acesso à Cooperativa foi pleiteada pelos cooperativados e construída com recursos financeiros da SUFRAMA. A pavimentação chega ao portão lateral da Cooperativa e necessita de manutenção estrutural.

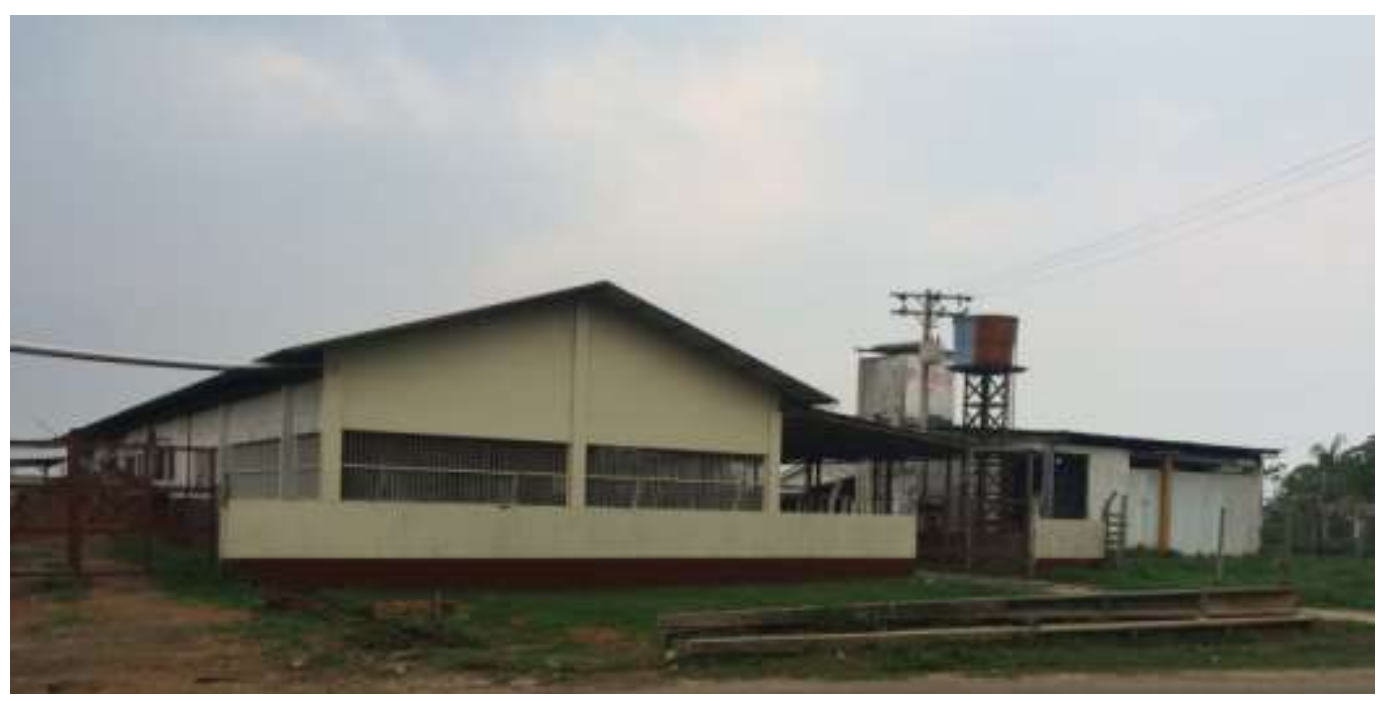

Figura 48 - Cooperativa de Açaí de Codajás e a fábrica de gelo.

A Sra. Franciani informou que a safra de 2016 (janeiro a agosto) foi bastante produtiva, porém, os cooperativados não venderam sua produção para a Cooperativa de Açaí de Codajás, em razão do não funcionamento da mesma.

A Cooperativa vem sendo responsável pela compra da produção total dos cooperativados, ela representa, portanto, um mercado garantido para os comerciantes de açaí. Nos anos de 2006 e 2007 a Cooperativa excedeu sua produção com as exportações, mas atualmente passa por um momento de crise econômica aliada a vários problemas que vêm se agravando. Neste ano de 2016, não foi possível a Cooperativa comprar a produção dos seus cooperativados, culminando com o seu fechamento, mas acredita-se que seja um momento passageiro e em breve ela possa retornar com suas atividades.

Diante deste fato, os cooperativados recorreram a uma nova cooperativa instalada recentemente em Codajás. Esta nova cooperativa encontrou um mercado favorável com a oferta do açaí maior do que a demanda. Com isso, os cooperativados tiveram que vender uma parte da sua produção a um valor inferior e o excedente da produção foi desprezado. É lamentável que os cooperativados não tenham vendido a produção total, ou seja, um trabalho árduo terminou sem rentabilidade, considerando que o açaí é um fruto perecível e exige uma 
comercialização imediata. Neste sentido, os cooperativados foram prejudicados com o não funcionamento da Cooperativa de Açaí de Codajás, desperdiçando uma grande parte da safra do ano de 2016.

De acordo com a Sra. Franciani, desde 2007, quando houve um crescimento econômico na Cooperativa de Açaí de Codajás, surgiram problemas de ordem monetária que inviabilizavam o pagamento dos cooperativados. Os trabalhos realizados pelos cooperativados com valores acima de $R \$ 2.000,00$ (dois mil reais) ficavam aprisionados pelo sistema bancário e só eram liberados após a carência de três dias. Este procedimento tornou-se um transtorno para os cooperativados que almejavam receber seu pagamento logo após a execução do trabalho. Então, a criação de uma entidade habilitada em transações bancárias com a finalidade de promover o pagamento sem restrição de valor e sem carência foi pensada e, desse modo, os problemas de ordem financeira da Cooperativa seriam minimizados e facilitados para o crédito rural. Assim, no ano de 2012, surgiu a CODCRED, uma Cooperativa de Crédito Rural e Economia Solidária de Codajás.

A CODCRED conseguiu sanar alguns problemas da Cooperativa, sendo necessário se entender melhor o seu funcionamento. Com a finalidade de se obter mais informações para a pesquisa, fizemos um contato e realizamos duas entrevistas presenciais com a Sra. Diane Sobreira da Silva, a vice-presidente da Cooperativa. Na primeira entrevista comentamos a formação da CODCRED e na segunda abordamos os resultados da CODCRED e seus novos direcionamentos.

A CODCRED foi fundada pelos seguintes organizadores: Sr. José Brito, Sra. Marlene Andrade, Sra. Maria Nézia e Sr. Antonio Ferreira (in memoriam).

A Sra. Diane mencionou em sua entrevista a obstinação dos fundadores e o enfrentamento das suas limitações, decorrentes do desconhecimento sobre o sistema bancário e o crédito rural. Vale ressaltar que os fundadores e interessados na formação da CODCRED eram trabalhadores agrícolas, que não tinham conhecimentos sobre movimentação bancária. Por isso os fundadores recorreram ao SEBRAE, para orientá-los sobre a dinâmica do sistema bancário e sobre a formação de uma cooperativa de crédito rural.

No decorrer dos anos, foram realizados vários cursos e treinamentos destinados a facilitar a formação da CODCRED e a capacitar as pessoas que assumiriam a diretoria da cooperativa. A CODCRED foi gradativamente conquistando cooperativados e ganhando credibilidade entre os moradores de Codajás. O objetivo da CODCRED era obter visibilidade no mercado local, e esse objetivo foi alcançado superando as expectativas. 
A CODCRED surgiu inicialmente para atender a demanda da Cooperativa de Açaí de Codajás mas, em virtude de um bom trabalho realizado, despertou o interesse de outros segmentos para também serem contemplados com o sistema de crédito rural. Então, foi necessário delimitar o público alvo da CODCRED seguindo as normas estabelecidas pelo regimento das cooperativas, pela Organização da Sociedade Civil de Interesse Público - OSCIP e pelas normas do Banco Central. Esta tomada de decisão foi vantajosa, porque exigiu que várias questões solicitadas pelo Banco Central fossem definidas e determinou legalmente o empréstimo para o trabalhador rural. Desta forma, ficou determinada a possibilidade de empréstimo aos proprietários, aos produtores e aos comerciantes de açaí.

A desvantagem foi a intervenção da rigorosa legislação, que restringiu a inscrição de novos cooperativados, consequentemente travando a prospecção de crescimento econômico da CODCRED.

A CODCRED assumiu normas rigorosas que não contemplavam as pessoas que esporadicamente realizavam trabalhos na zona rural, como por exemplo o capinador, que limpa o açaizal antes e depois de cada safra e o carregador braçal, que transporta as sacas de açaí durante o período de safra, pois apesar de ambos serem classificados como trabalhadores rurais, não têm comprovação legal de suas atividades. Existem, como essas, várias atividades que se configuram como trabalho rural em caráter temporário, mas que não são contempladas pela CODCRED. Na tentativa de proporcionar maior abrangência de empréstimo, a cooperativa viabilizou um documento para facilitar o pagamento para atividades temporárias.

No ano de 2013, houve um atraso nos serviços por parte da CODCRED, decorrente da inexperiência dos organizadores com o sistema bancário. Para sanar este problema a cooperativa recorreu, novamente, ao SEBRAE. A orientação foi no sentido de buscar auxílio com a Instituição de Crédito Solidário CREDISOL, criada no ano de 1999, por iniciativa da Agência de Fomento de Santa Catarina S.A. - BRADESCO com apoio técnico do SEBRAE.

A CREDISOL tem como finalidade facilitar o acesso ao crédito para pessoas que trabalham por conta própria, mesmo que ainda na informalidade. Os serviços prestados pela CREDISOL significam acesso ao crédito de forma simples e a oportunidade de receber orientação técnica para fortalecer o comércio, sem custos adicionais. A partir da CREDISOL foram facilitadas novas frentes de crédito para os trabalhadores rurais em caráter temporário. 
A Sra. Diane julga que os benefícios proporcionados pela CREDISOL são inúmeros, considerando-se que as negociações com a instituição encontram-se ainda em fase inicial de conversa. Ela acredita que com a formalização legal desta parceria os benefícios serão maiores e até extensivos aos moradores de Codajás.

Em resumo, as cooperativas que estão envolvidas com o sistema produtivo do açaí enfrentam problemas de ordem geopolítica que exaustivamente foram mencionados no decorrer desta pesquisa. Cabe lembrar, também, que o Amazonas possui uma dinâmica econômica complexa; é um estado de grande extensão territorial; em algumas localidades ocorre uma baixa densidade demográfica; e é caracterizado pela complexa locomoção e acessibilidade. Além disso, a essa complexidade podem ser acrescidas questões climáticas, como períodos de longa estiagem e chuvas fortes; questões de acesso a tecnologia da informação, conjugando computador e internet; e por fim questões de sistematização no oferecimento de cursos educacionais e técnicos.

É compreensível que o somatório destes problemas desestimulem as atividades econômicas, evidenciando o quanto é difícil implementar atividades em locais em que prevalecem o assistencialismo público e a indiferença ao trabalho solidário. Questões culturais que remetem à formação do estado do Amazonas, e que tiveram sua origem em um problema de ordem geopolítica, são recorrentes nos dias atuais.

Historicamente existem documentos que comprovam alianças entre os portugueses e os índios, que foram fundamentais para a construção de pontes, estradas e vilas. Contudo, estes feitos não representam um marco histórico na formação urbanística do Estado do Amazonas. Isso porque os índios respondiam às alianças conforme seus interesses, apresentando um comportamento indiferente a qualquer demanda que não lhes interessasse diretamente. Este comportamento vem sendo reproduzido pelos amazonenses em geral.

O estado do Amazonas incorporou a indiferença e este posicionamento se tornou uma questão cultural que se transformou em um hábito corriqueiro. Um problema antigo que permanece nos dias atuais, e é reproduzido pelos cooperativados. Este problema de indiferença e inércia dos cooperativados dificulta os dirigentes das cooperativas, que por sua vez são obstinados e motivados ao trabalho solidário, a buscarem o desenvolvimento das mesmas. 


\subsubsection{2}

\section{Levantamento da infraestrutura e equipamentos da Cooperativa de Açaí de Codajás}

A Cooperativa de Açaí de Codajás compreende um prédio com instalações projetadas para o beneficiamento da polpa do açaí, e consiste em oito ambientes: recepção, produção, sala de controle de qualidade, envase, almoxarifado, câmara de congelamento, câmara de resfriamento e sala de expedição. Os ambientes estão alocados conforme a sequência do processo produtivo para o beneficiamento da polpa de açaí.

\section{- Recepção}

A recepção (Figura 49) é o primeiro ambiente da Cooperativa, local em que a senhora Franciani recebe a colheita dos extrativistas. Neste ambiente, é feita uma seleção para verificar a maturação do açaí e os frutos estragados. Após esta conferência, os frutos verdes e os frutos deteriorados são descartados. Em seguida, os frutos selecionados são pesados e encaminhados para o processo de higienização. A recepção da Cooperativa é constituída por dois equipamentos e dois tanques. O equipamento situado do lado esquerdo da Figura 49 é destinado à primeira lavagem, com a finalidade de retirar os detritos oriundos da mata: galhos, pedras, areia e insetos. $O$ tanque de alvenaria com três compartimentos, revestido de azulejo branco, é destinado para a segunda lavagem. O tanque de material aço inoxidável com dois compartimentos é destinado à imersão do açaí por um período de duas horas, com o propósito de facilitar a liberação entre a polpa e a semente. Este processo é denominado maceração.

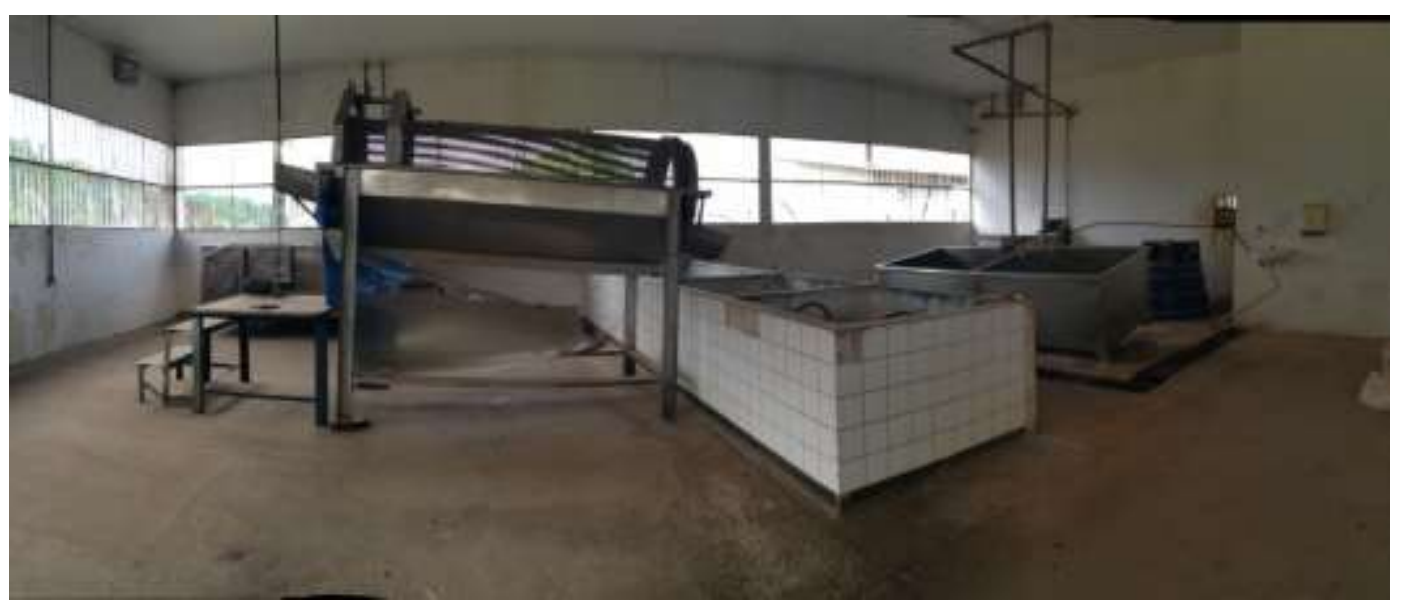

Figura 49 - Recepção da Cooperativa de Açaí de Codajás. 
O segundo e último equipamento (Figura 50), localizado no fundo da sala, é uma esteira rolante com a função de transportar os frutos lavados e macerados para o outro ambiente da Cooperativa, a área da produção que, por sua vez, encaminha os frutos para a despolpadeira.

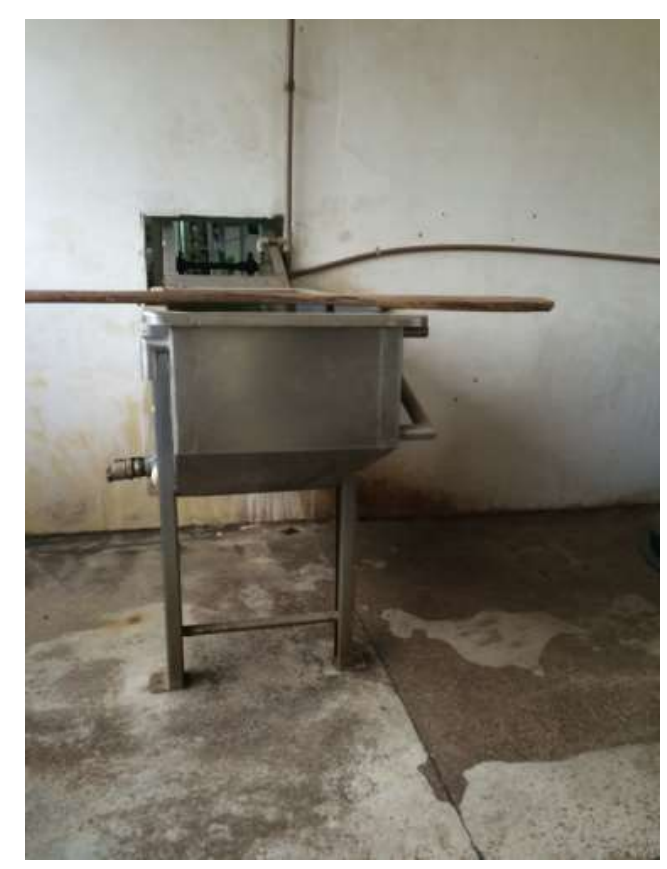

Figura 50 - Esteira rolante para transportar os frutos para a despolpadeira que se encontra na sala de produção.

\section{- Produção}

A produção é o segundo ambiente, destinado ao beneficiamento da polpa do açaí, ou seja, a despolpagem do fruto. Um ambiente que exige um determinado padrão de higiene. Na entrada deste ambiente (Figura 51), existe um protocolo de higienização para os funcionários, que compreende a limpeza das botas e a lavagem das mãos. Logo na porta, existe um declive no piso que retém água formando uma pequena piscina. Em seguida, uma pia, que se encontra quebrada, com um cartaz fixado na parede orientando a higienização das mãos (Figuras 52a e 52b). Todo este protocolo de higiene é exigido na despolpagem do fruto, ambiente da produção, para evitar o contato com a polpa de açaí e evitar a contaminação no produto final, que é um alimento. 


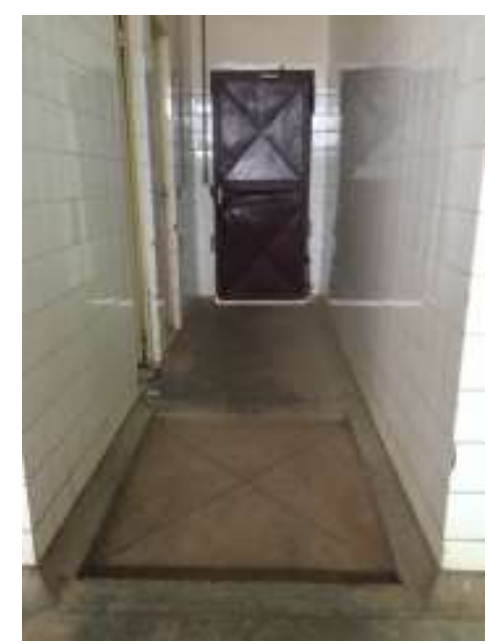

Figura 51 - Entrada no ambiente da produção da Cooperativa.
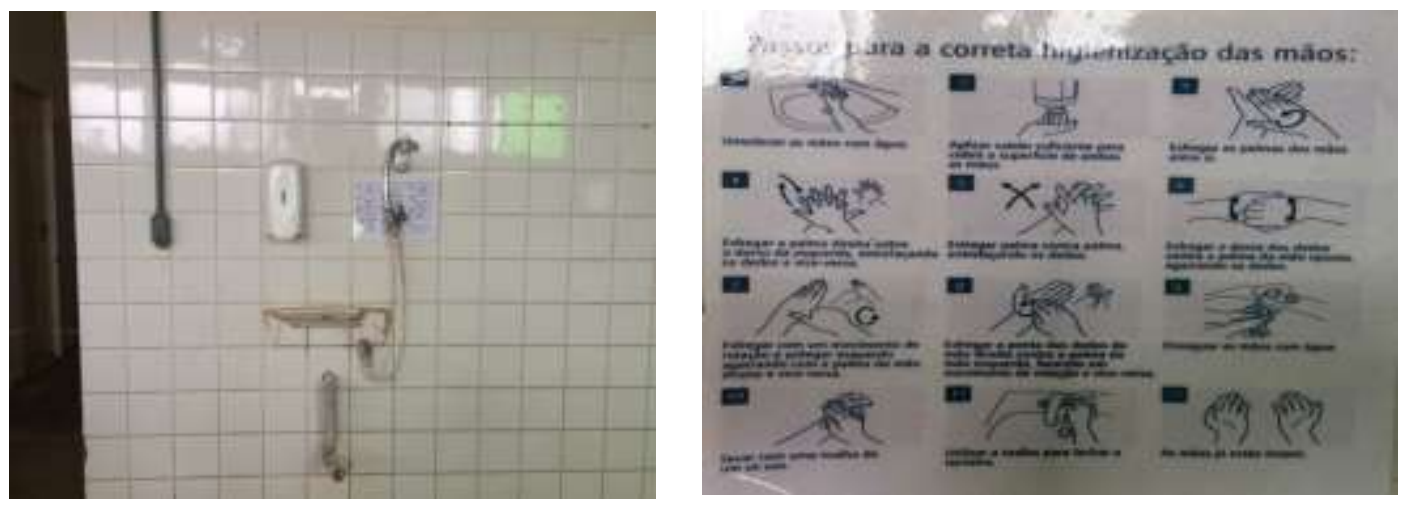

Figuras 52 (a) Pia quebrada na entrada da produção da Cooperativa. (b) Cartaz ampliado para orientar a higienização das mãos.

Neste ambiente da produção estão dispostos, conforme se vê na Figura 53 da esquerda para a direita: uma despolpadeira industrial, uma máquina de pasteurização e dois tanques de aço inoxidável.

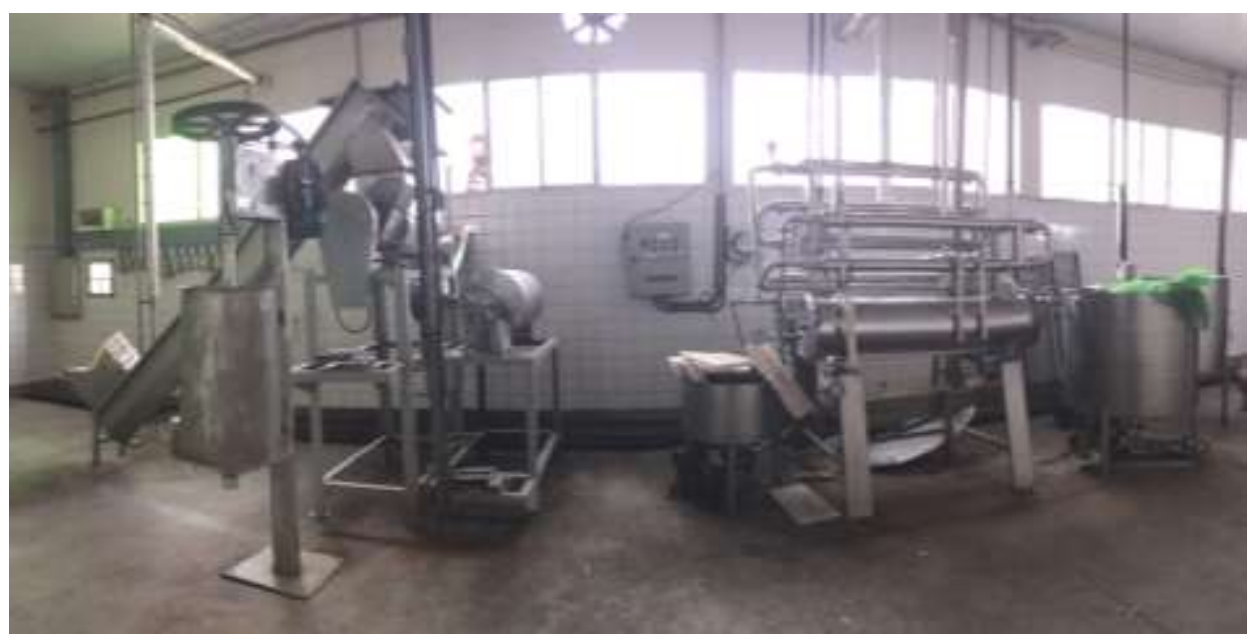

Figura 53 - Produção da Cooperativa. 
A máquina despolpadeira industrial (Figura 54) foi adquirida com a fundação da fábrica de beneficiamento juntamente com todos os outros equipamentos. Devido à falta de manutenção ela está inoperante e foi substituída por uma máquina despolpadeira semi-industrial (Figura 55). A finalidade da máquina despolpadeira é retirar a polpa da semente. Finalizada esta etapa, a polpa é transferida para a máquina de pasteurização, e as sementes, lançadas para a área externa da Cooperativa.

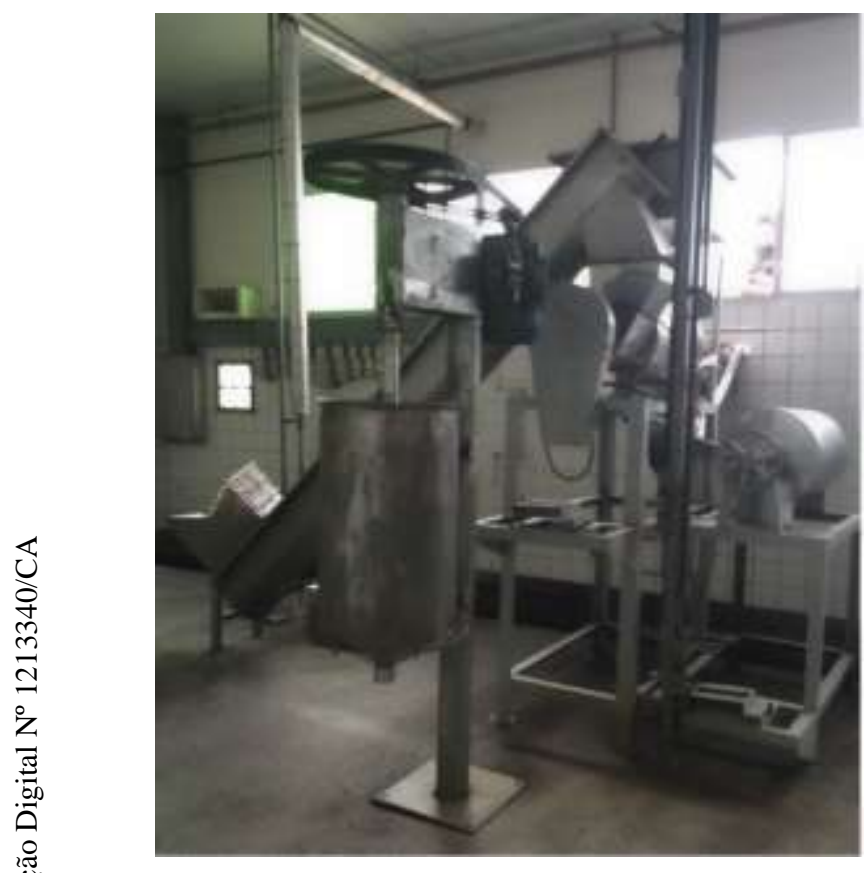

Figura 54 - Máquina despolpadeira industrial inoperante. 


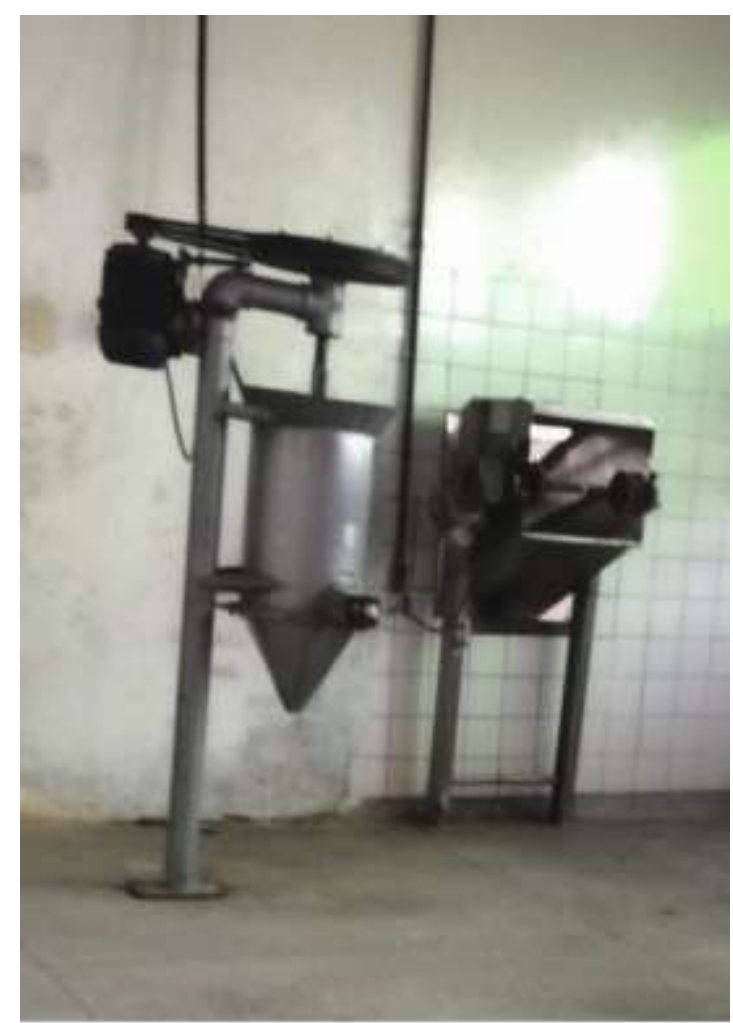

Figura 55 - Máquina despolpadeira semi-industrial.

Da máquina despolpadeira industrial é utilizada apenas uma parte: o corredor que transporta as sementes para a área externa da Cooperativa (Figura 56).

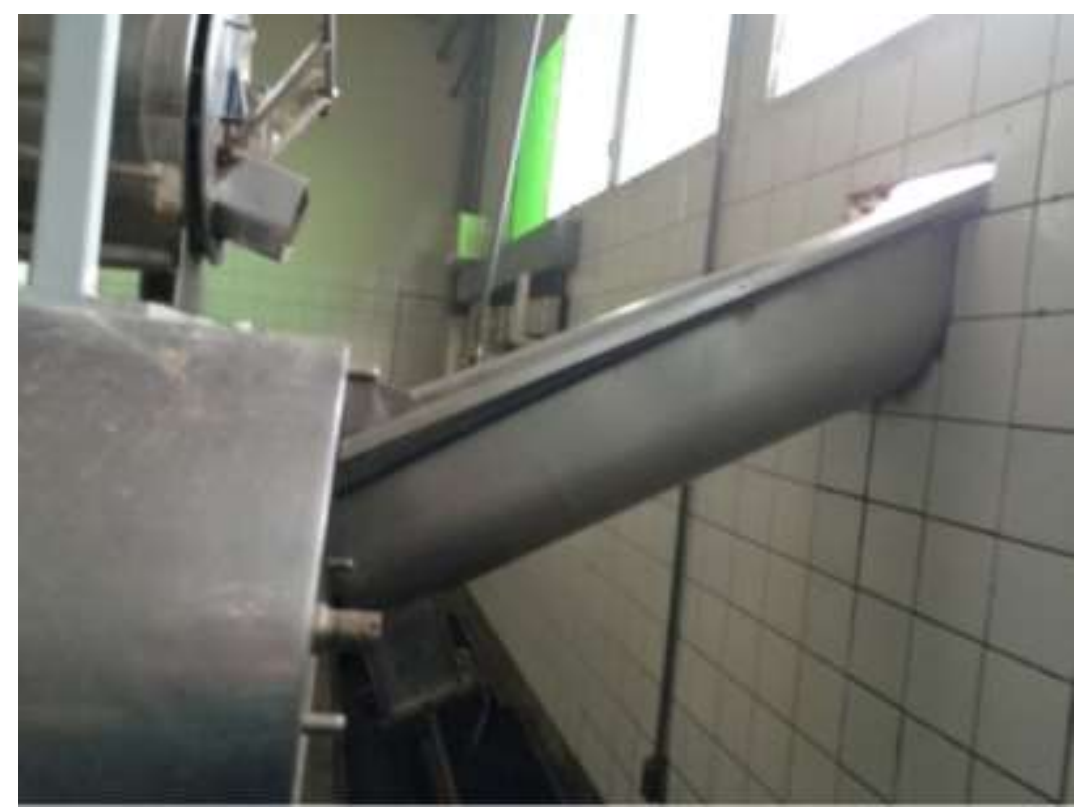

Figura 56 - Detalhe da máquina despolpadeira industrial que transporta as sementes para a área externa da Cooperativa.

A máquina de pasteurização (Figura 57) promove um choque térmico na polpa quando ela é submetida a uma elevada temperatura em um tanque e a uma 
baixa temperatura no outro tanque. O processo da pasteurização já foi comentado anteriormente neste capítulo. Os tanques de aço inoxidável (Figura 58) acolhem a polpa que será embalada em saco plástico.

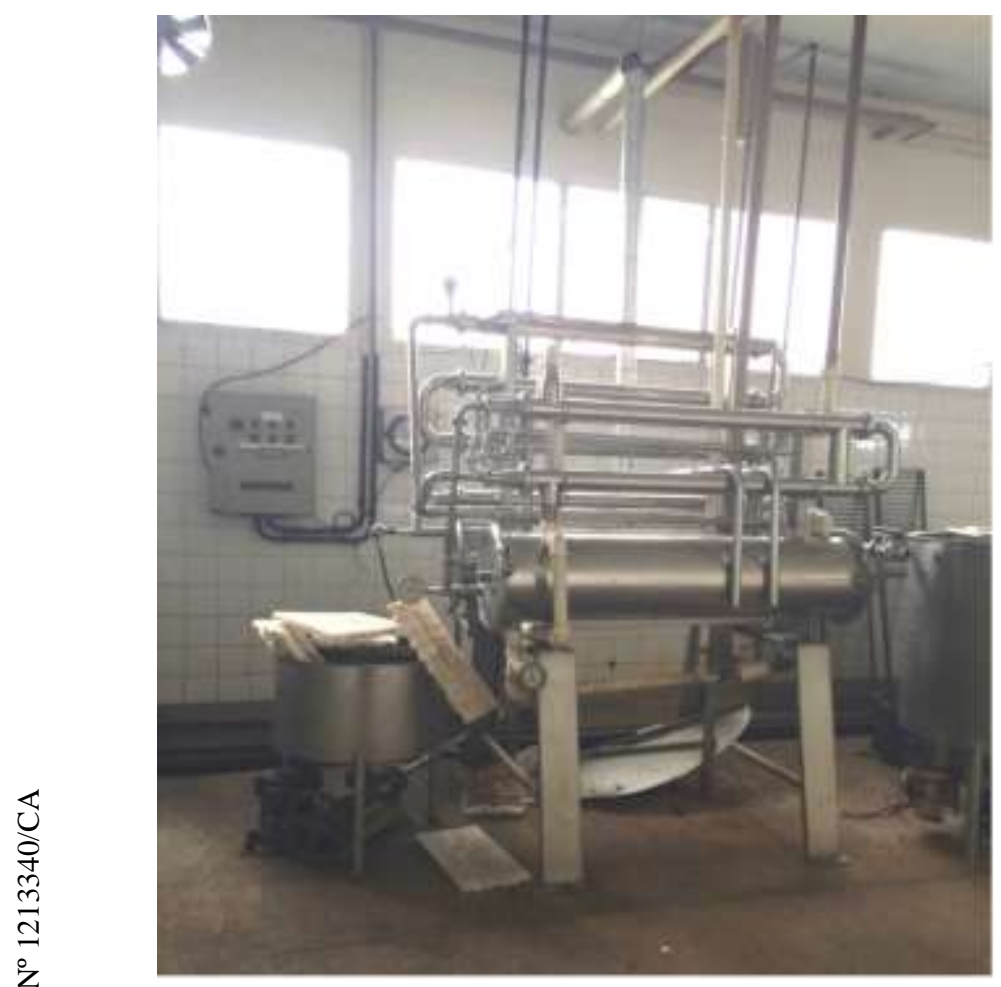

Figura 57 - Máquina de pasteurização.

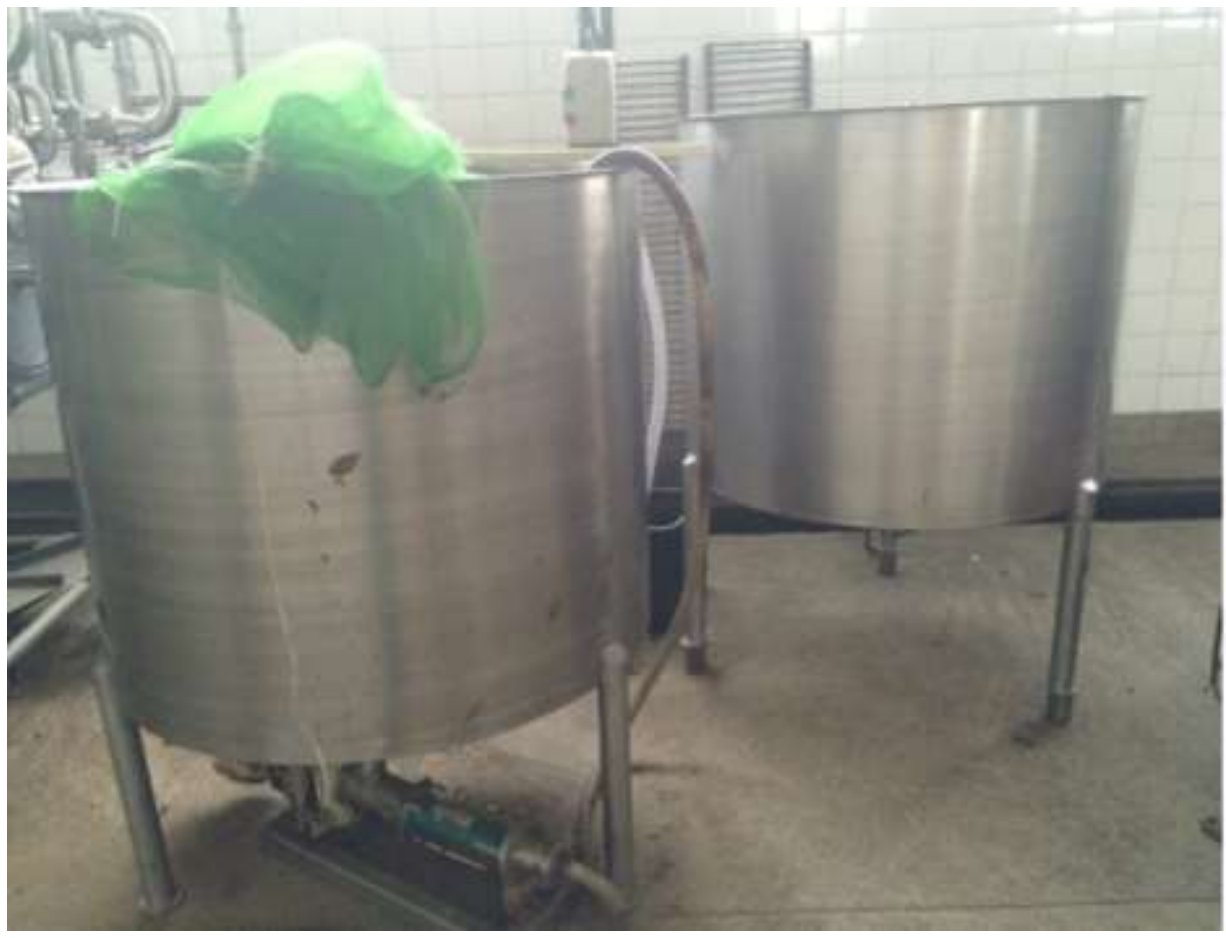

Figura 58 - Tanques que comportam a polpa para ser embalada. 


\section{- Sala de Controle de qualidade e envase}

A Sala de Controle de qualidade (Figura 59) é o terceiro espaço físico da Cooperativa, sendo o ambiente em que é verificada a consistência da polpa e determinado o seu tipo, conforme a classificação: A (polpa mais densa), B (polpa menos densa, intermediária) e C (polpa mais rala ou polpa popular). Nesta sala, também, ocorre o envase da polpa em saco plástico.

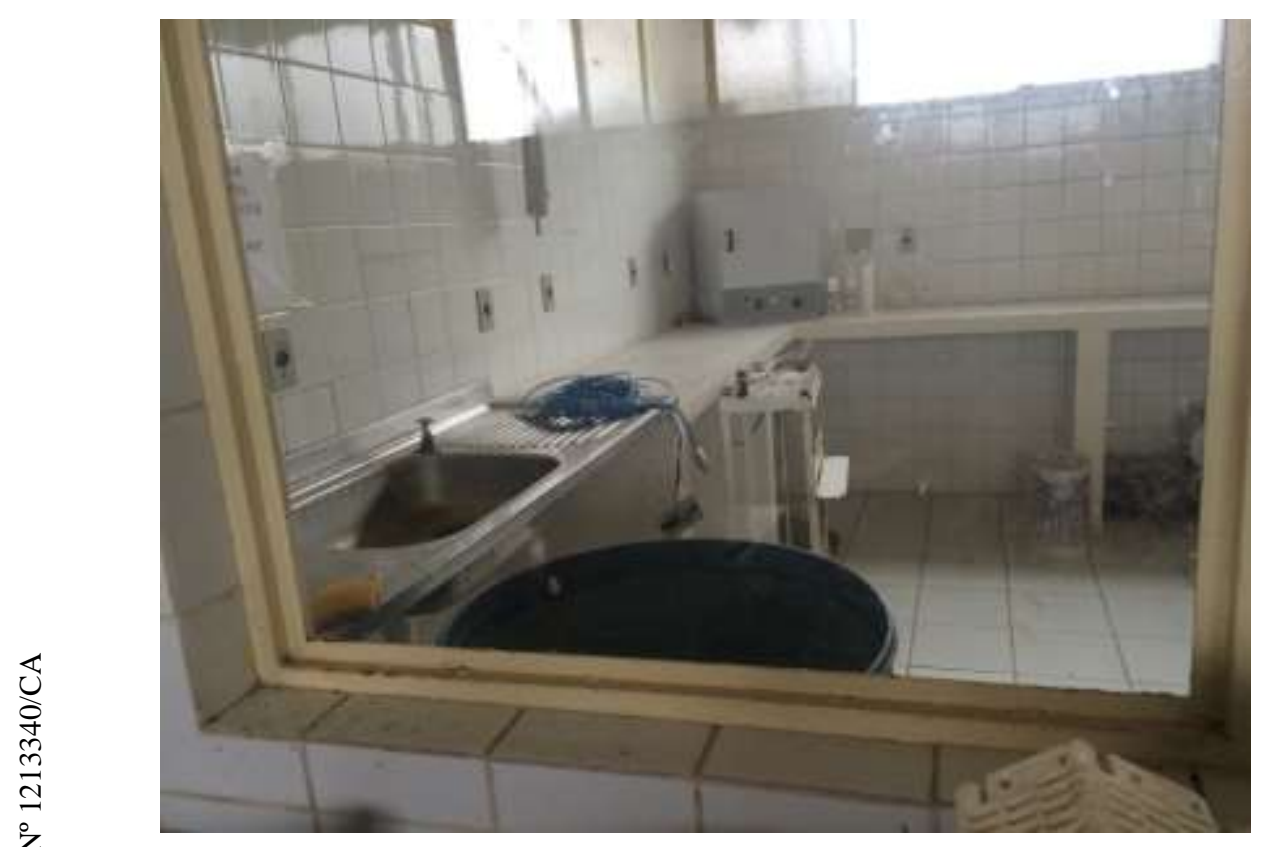

Figura 59 - Sala de controle e qualidade e envase.

\section{- Almoxarifado}

O almoxarifado comporta as embalagens de sacos plásticos com tamanhos diversificados (Figura 60).

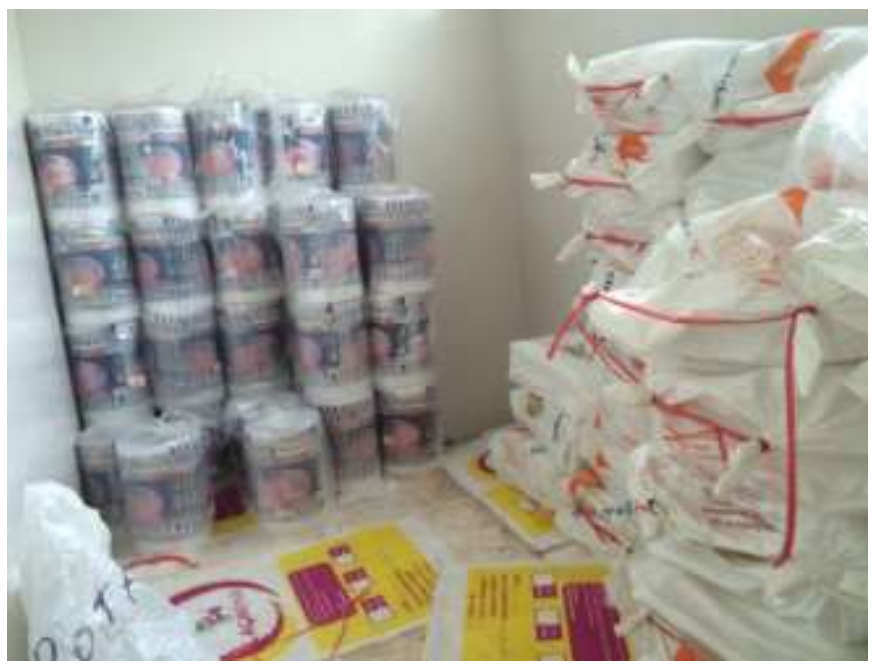

Figura 60 - Almoxarifado. 


\section{- Câmara de congelamento da polpa}

A câmara de congelamento (Figura 61) compreende uma ampla sala onde se congela a polpa. Este ambiente proporciona acesso à câmara de resfriamento que, por sua vez, mantém a polpa resfriada, e ainda um outro ambiente, também refrigerado, com porta para a área externa posterior do prédio (Figura 62), que tem acesso ao rio Solimões e tem por finalidade facilitar 0 transporte para o barco da Cooperativa, monitorado pelo vice-presidente. A sala de congelamento da polpa fica situada no final do ambiente da produção, ficando o escritório e a sala de controle de qualidade e envase do lado esquerdo.

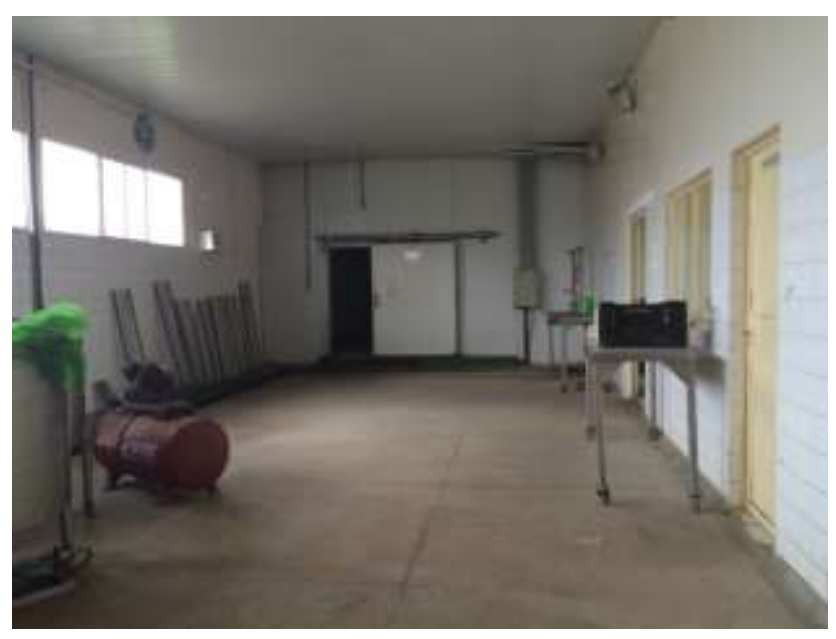

Figura 61 - Sala de congelamento da polpa.

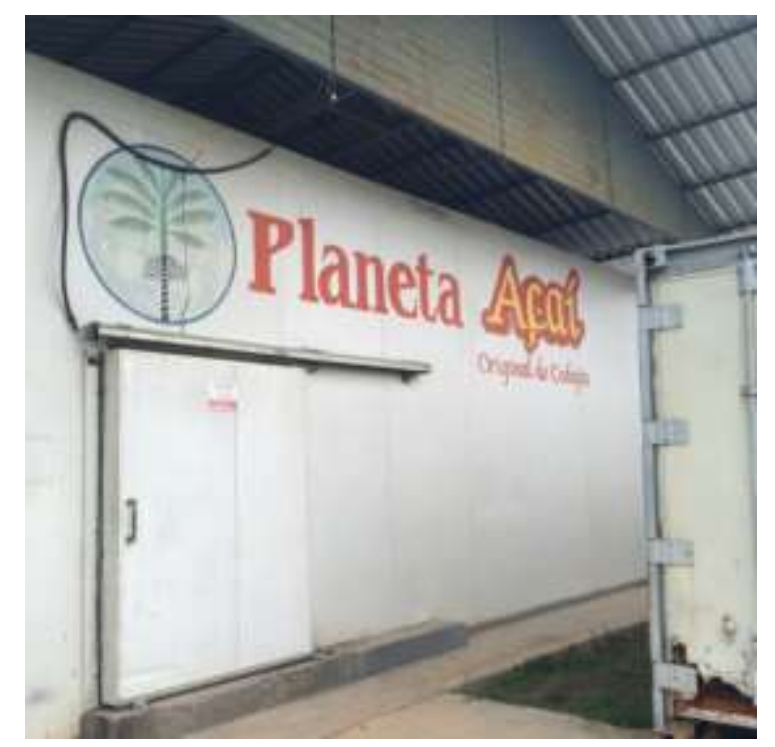

Figura 62 - Porta de saída da câmara de congelamento da polpa. 


\section{- Escritório}

O escritório da Cooperativa (Figura 63) é uma sala com mesa de trabalho, mesa de reunião, cadeiras, estante de metal, armário-fichário e computador local em que é feito o pagamento à vista aos extrativistas pela venda do açaí.
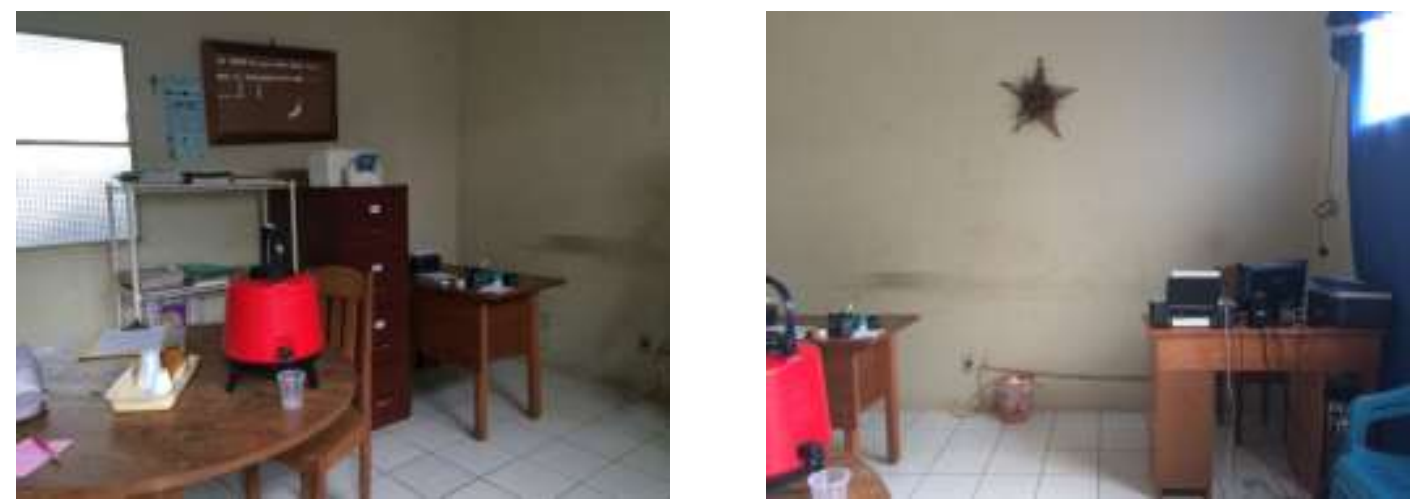

Figura 63 - Escritório da Cooperativa.

$\mathrm{Na}$ área lateral externa, encontra-se o caminhão da Cooperativa (Figuras 64a e 64b) em condições precárias de funcionamento. Ao lado do caminhão, vêse uma plataforma motorizada sobre trilho, onde os cooperativados poderiam colocar sua produção vinda do rio Solimões, em cuja margem se encontram os fundos da Cooperativa (Figuras 65). Tanto o caminhão quanto a plataforma estão mal conservados. A plataforma foi retirada do trilho (por isso não aparece na foto 65$)$, porque o equipamento foi desativado há dois anos.
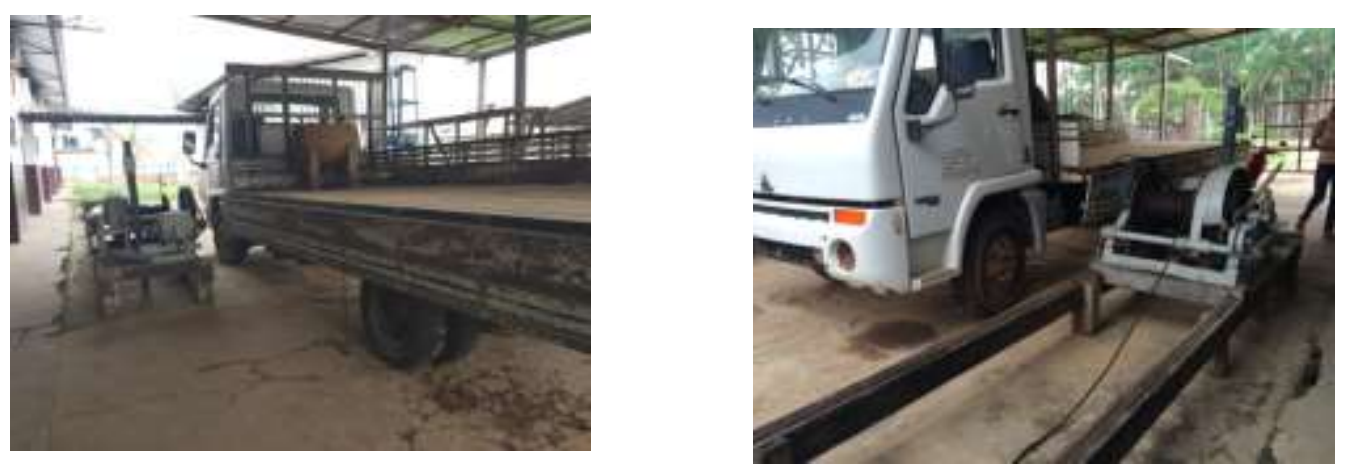

Figuras 64 - (a) Caminhão da Cooperativa. (b) Plataforma motorizada sobre trilho. 

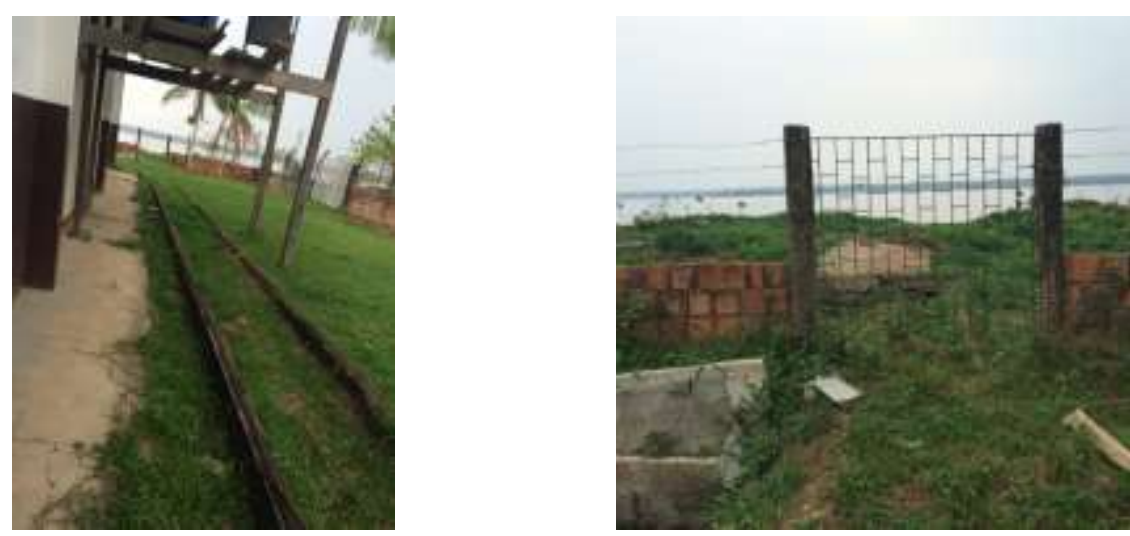

Figuras 65 - (a) Trilho da plataforma. (b) Limite da Cooperativa com o rio Solimões.

Por fim, o contêiner (Figura 66) está desativado, por necessitar de reparo em uma peça para que possa manter o seu interior refrigerado. Em uma das extremidades do contêiner, existe um ponto danificado pela ferrugem.

Atualmente, a presidente da Cooperativa aguarda a obtenção de recurso financeiro para fazer a manutenção necessária. O contêiner foi utilizado sobre a balsa para transportar a polpa de açaí congelada. A balsa ficou sem condições de navegação e foi substituída por um barco.

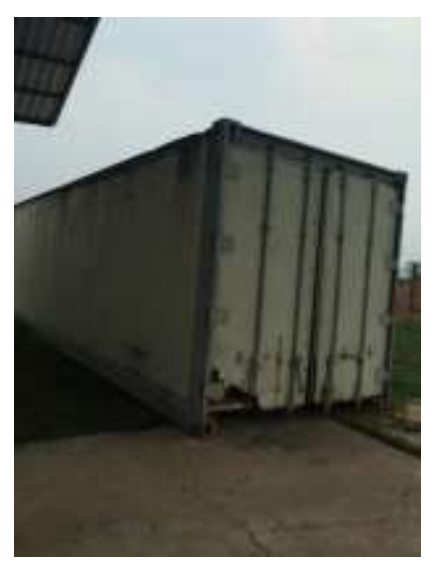

Figura 66 - Contêiner da Cooperativa.

Na opinião da senhora Franciani, ocorre um acúmulo de sementes sem destino manejado e sem aproveitamento. As sementes que são descartadas pela despolpadeira são jogadas na lateral da Cooperativa (Figura 67) e formam um grande amontoado, resultante da produtividade, ao longo dos seis meses. Uma parte é vendida para ser utilizada como ração de animais, a outra parte é usada como adubo (Figura 68), mas este procedimento não é o suficiente para acabar totalmente com o resíduo que é acumulado durante o semestre. 


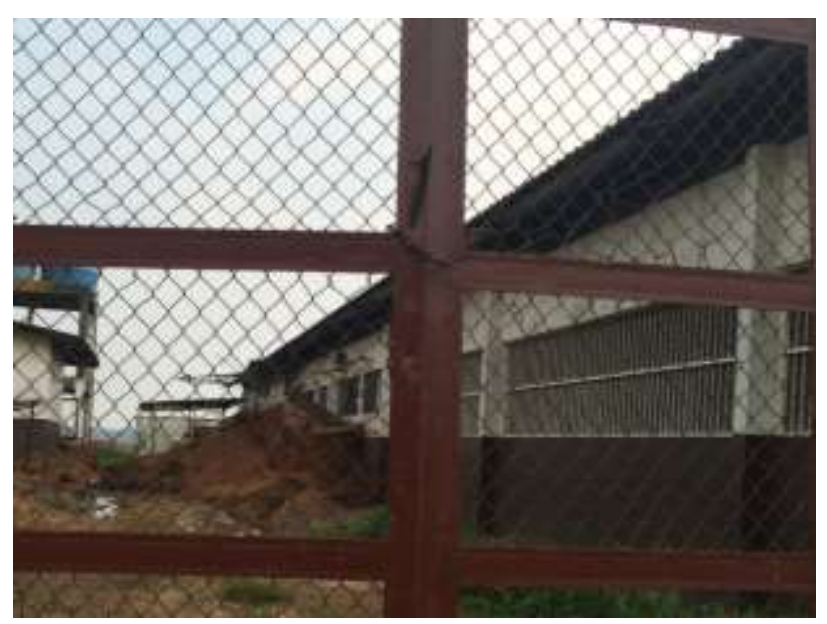

Figura 67 - Resíduo de sementes acumulados na lateral da Cooperativa.

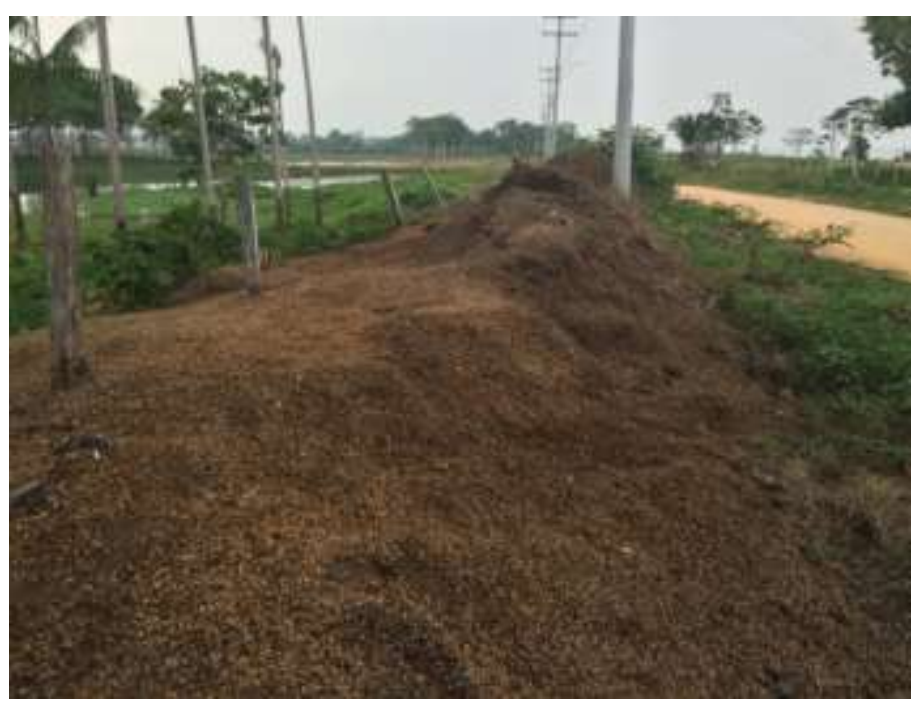

Figura 68 - Resíduo de sementes utilizado como adubo.

Além da visita à Cooperativa de Açaí de Codajás, foi feito um reconhecimento no plantio manejado de açaí em uma das propriedades de um dos cooperativados. O plantio é da espécie Euterpe precatoria (Figuras 69 e 70) conhecido popularmente como açaí solteiro. Esta denominação está relacionada com seu tronco unitário. 


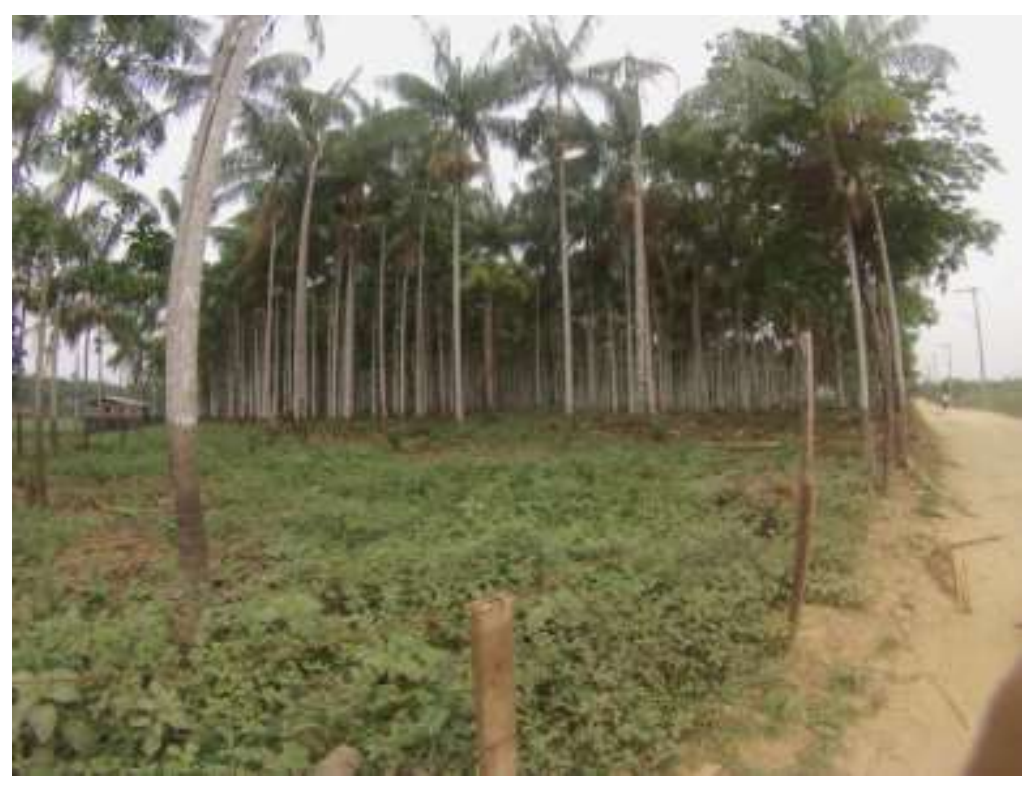

Figura 69 - Plantio de açaí (Euterpe precatoria).

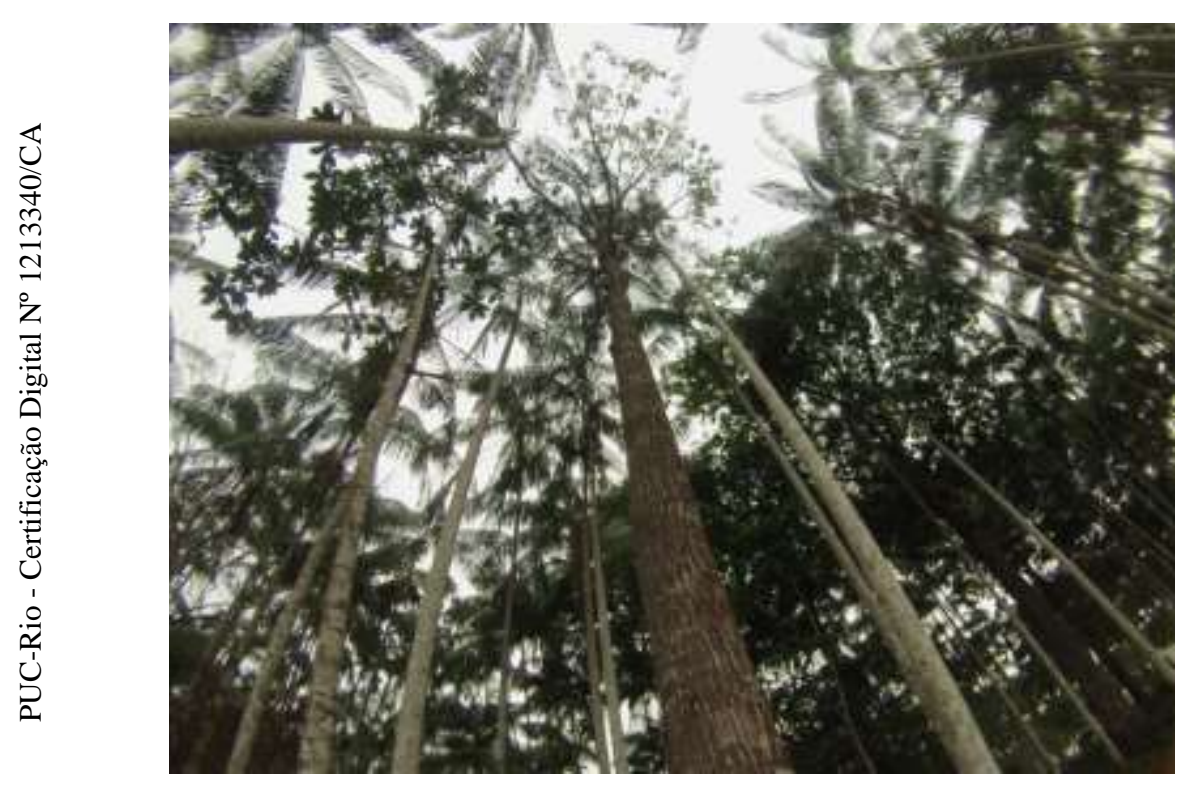

Figura 70 - Imagem das palmeiras vistas de baixo para cima.

Na visita ao plantio de açaí, nos chamou a atenção uma casa de palafita (Figura 71), construção típica da região, edificada sobre estacas de madeira, apropriada para áreas alagadiças. 


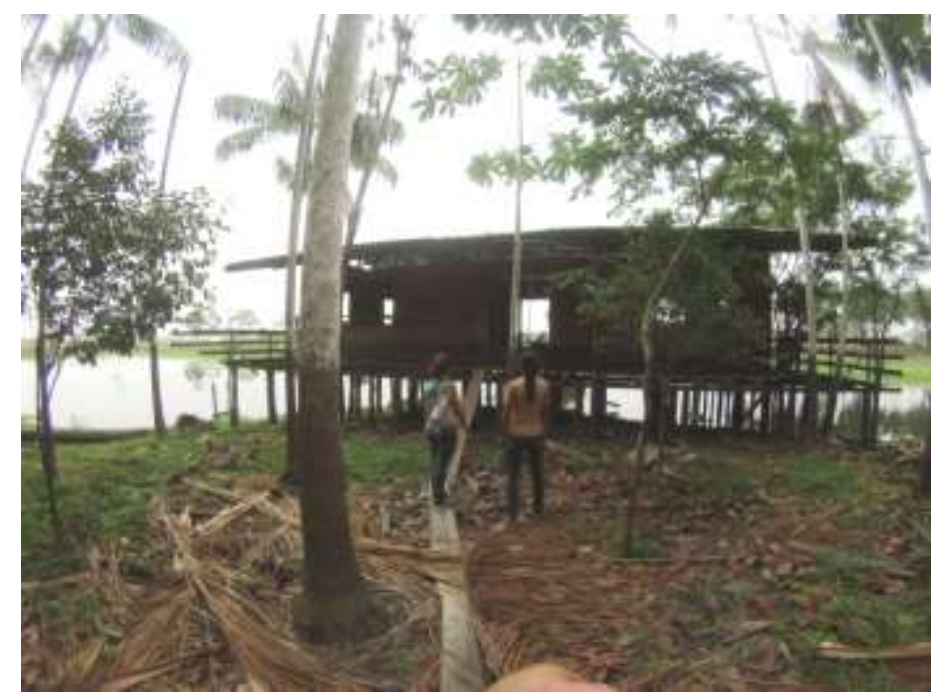

Figura 71 - Casa de palafita, apropriada para áreas alagadiças.

Nas visitas de campo verificamos que o plantio de açaizeiro em Iranduba é da espécie Euterpe oleracea, mais abundante no estado do Pará, espécie em que as palmeiras abrangem várias estirpes, e a altura é menor, conhecida popularmente como açaí touceira (Figura 72). O açaizeiro de Codajás, por sua vez, é da espécie Euterpe precatoria, que compreende uma única estirpe e é mais alto, sendo denominado pelos populares de açaí solteiro (Figura 73).

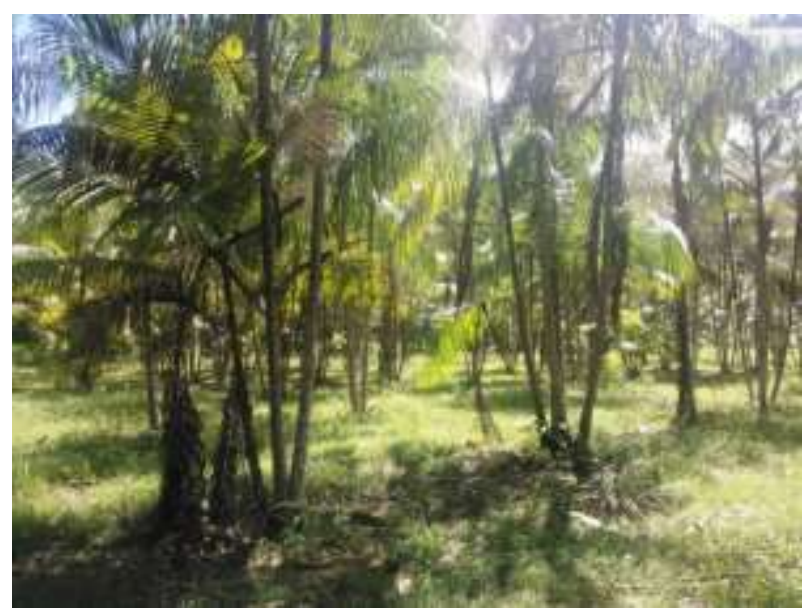

Figura 72 - Açaizeiro de Iranduba. 


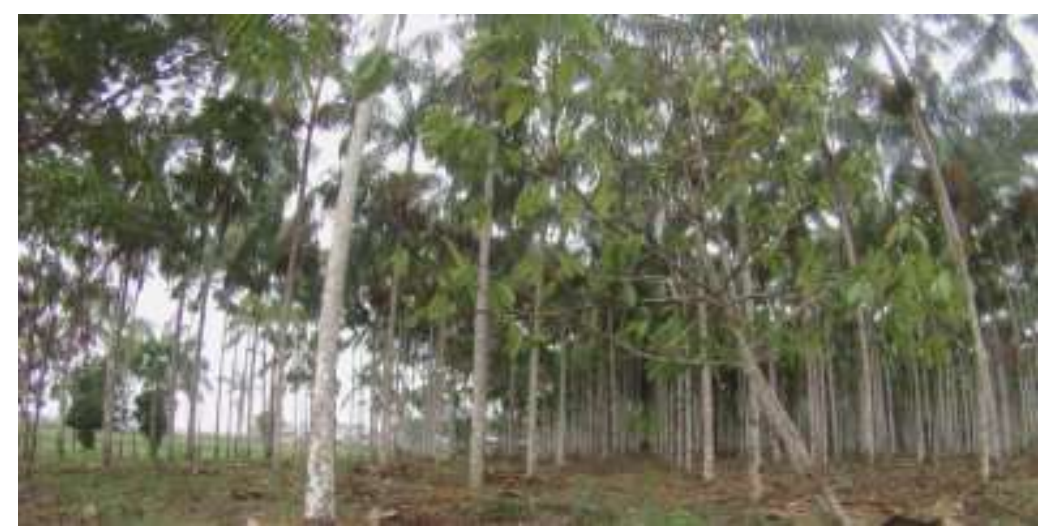

Figura 73 - Açaizeiro de Codajás.

O capítulo 4 buscou traçar um reconhecimento a respeito dos aspectos morfológicos do fruto, e um levantamento da cadeia produtiva e seus respectivos problemas, trazendo a Cooperativa de Açaí de Codajás como objeto de estudo.

Ao longo do capítulo, foram delineados os entraves que impedem a estabilidade produtiva da Cooperativa. Em síntese, os obstáculos que investigamos para propor otimizações foram: o desinteresse por parte dos cooperativados; o período de estagnação das atividades na entressafra; o surgimento de um novo empreendimento no município que aponta uma possível concorrência; ausência de conhecimento relacionado ao cooperativismo; a influencia negativa da cultura assistencialista no estado do Amazonas; os equipamentos quebrados e desativados; a formação residual e 0 não aproveitamento das sementes.

Em um primeiro momento, agrupamos esses entraves em categorias, com a finalidade de facilitar possíveis intervenções projetuais de design no desenvolvimento de uma proposta de modelo conceitual para a produção do açaí, que se segue no capítulo 5, com base no diagnóstico feito no estudo de campo realizado na Cooperativa de Açaí de Codajás. 


\section{5}

\section{Desenvolvimento de uma proposta conceitual para a produção do açaí}

Após a visita ao município de Codajás, foi selecionada, como objeto de estudo para a intervenção do design sustentável, a Cooperativa de Açaí de Codajás, por ser o maior produtor de açaí da região e também pela infraestrutura existente, que possibilita o beneficiamento do fruto.

Apesar das condições precárias, a Cooperativa é referência como modelo produtivo do açaí no estado do Amazonas, devido a sua produtividade, aos plantios nos arredores próximos à Cooperativa, ao cadenciamento de atividades produtivas, à estrutura física predial e à instalação fabril.

Com base na delimitação das metodologias emergentes da sustentabilidade, apresentamos uma proposta de modelo conceitual para a produção do açaí, tomando como base a Cooperativa de açaí de Codajás.

\section{1}

Síntese dos critérios para o desenvolvimento de um modelo conceitual, com base nas metodologias sustentáveis

Retomando a Tabela 1 - Valores das metodologias emergentes sustentáveis, chegamos a uma síntese de critérios que devem nortear a proposta de um modelo conceitual para a produção do açaí:

- Minimizar os impactos ambientais ocorridos durante a cadeia produtiva, da colheita do açaí até o descarte das sementes - prioridades do ecodesign.

- Atender a grupos menos favorecidos econômica, social e politicamente, proporcionando uma expectativa de qualidade de vida, maior produtividade econômica e empoderamento político - prioridades do design social.

- Contar com a participação dos extrativistas e dos envolvidos na cadeia produtiva do açaí, ou seja, trabalhar um modelo elaborado de forma colaborativa com a comunidade rural - prioridades do design participativo.

- Considerar a cultura material e valorizar os artefatos empregados atualmente na cadeia do açaí, no processo de elaboração de novos 
modelos para o extrativismo - prioridades do design para a sustentabilidade e a tecnologia apropriada.

Vale lembrar que para o desenvolvimento do modelo são valorizados os conhecimentos e práticas da cadeia produtiva do açaí aplicados no estado do Amazonas. Entretanto, em algumas situações a experiência do estado do Pará é trazida como referência.

\section{2}

\section{Síntese das etapas do modelo produtivo do açaí e situações para possível intervenção do design}

Inicialmente, revisitamos as atividades da cadeia produtiva do açaí nas quais identificamos impactos ambientais e sociais. Neste sentido, colocamos as etapas sob minuciosa verificação destes impactos, para avaliar e apontar possíveis soluções já existentes, relacionadas aos problemas da cadeia produtiva. Apresentamos, em seguida, um estudo de desenvolvimento de alternativas, empregando metodologia de design que congrega os valores sustentáveis.

Vale ressaltar que as etapas da cadeia produtiva do açaí selecionadas para avaliação nesta pesquisa, e possível intervenção do design, são: colheita do açaí, debulhamento, despolpamento, acondicionamento, transporte e consumo.

Neste momento, cabe um mapeamento da problemática entre os plantios e a Cooperativa de Açaí de Codajás. Alguns problemas diagnosticados na Cooperativa foram descritos pela senhora Franciani, outros foram observados durante a pesquisa de campo com um olhar apurado, entendendo que é possível a intervenção direta do design como contribuição para todo o processo.

Um outro ponto importante, detectado juntamente com a minha orientadora, está relacionado ao potencial ainda não explorado da Festa Cultural do Açaí em Codajás. A partir de uma abordagem de design sustentável, pode-se ampliar os efeitos benéficos da festa, fazendo com que ações duradouras, promissoras tanto para os extrativistas como para todo o município, sejam planejadas em função do evento.

No mapeamento, foram destacadas as atividades da colheita, do debulhamento e o acúmulo de sementes. Estas atividades representam um entrelaçamento de problemas que sinalizam possibilidades para a intervenção do design. 
Neste sentido, verificamos que o modelo produtivo do açaí em Codajás consiste em um conjunto interligado de problemas de naturezas distintas. Com a finalidade de ter uma visão geral, a problemática foi classificada em três grandes categorias - administrativo-financeira, técnica e cultural - e organizada graficamente por meio de um organograma, para facilitar a compreensão da situação atual da Cooperativa (Figura 74).

\begin{tabular}{|c|c|c|}
\hline $\begin{array}{l}\text { ADMINISTRATIVO- } \\
\text { FINANCEIRO }\end{array}$ & CULTURAL & TÉCNICO \\
\hline $\begin{array}{l}\text { Concentração das atividades } \\
\text { da Cooperativa em poucas } \\
\text { pessoas }\end{array}$ & $\begin{array}{l}\text { Jovens desinteressados pela } \\
\text { atividade agrícola }\end{array}$ & Escalada no açaizeiro \\
\hline $\begin{array}{l}\text { Comportamento } \\
\text { assistencialista do estado }\end{array}$ & $\begin{array}{l}\text { Potencial da Festa Cultural do } \\
\text { Açaí pouco explorado }\end{array}$ & Debulhamento dos cachos \\
\hline $\begin{array}{l}\text { Comercialização da polpa sem } \\
\text { o selo orgânico }\end{array}$ & $\begin{array}{l}\text { Ausência de cursos técnicos e } \\
\text { motivacionais }\end{array}$ & $\begin{array}{l}\text { Acúmulo e não aproveitamento } \\
\text { de sementes }\end{array}$ \\
\hline $\begin{array}{l}\text { Máquinas e equipamentos } \\
\text { quebrados e/ou necessitando } \\
\text { manutenção }\end{array}$ & & \\
\hline $\begin{array}{l}\text { Fornecimento de energia } \\
\text { bloqueado }\end{array}$ & & \\
\hline $\begin{array}{l}\text { Estagnação das atividades na } \\
\text { entressafra }\end{array}$ & & \\
\hline Acúmulo de sementes & & \\
\hline $\begin{array}{l}\text { Instalação de uma nova } \\
\text { indústria concorrente }\end{array}$ & & \\
\hline
\end{tabular}

Figura 74 - Organograma da problemática da Cooperativa de açaí de Codajás.

$\mathrm{Na}$ categoria administrativo-financeira, compete à presidente da Cooperativa a execução das atividades, a renovação do selo orgânico, a recuperação das máquinas quebradas e das instalações precárias, as ações para minimizar os problemas da estagnação durante a entressafra, além de traçar estratégias para enfrentar a instalação de uma indústria concorrente de beneficiamento de açaí em Codajás; e ao vice-presidente o gerenciamento do barco.

$\mathrm{Na}$ categoria cultural, verifica-se o não envolvimento dos cooperativados nas atividades da Cooperativa e o desinteresse dos jovens pela atividade produtiva do açaí. Nota-se também que o potencial da Festa Cultural do Açaí, não está sendo plenamente explorado.

Por fim, na categoria técnica, são apontados os problemas de periculosidade do ato de escalar o açaizeiro com a peconha; de morosidade e de 
insalubridade da atividade rústica de debulhar os cachos de açaí; e de acúmulo e não aproveitamento das sementes do açaí.

A seguir aprofundaremos algumas questões relacionadas à problemática do modelo produtivo do açaí de Codajás.

\section{- Problemas no âmbito administrativo-financeiro}

As várias funções exercidas pela presidente na Cooperativa e as várias responsabilidades que assume, ficando o vice-presidente com o gerenciamento do barco, fazem com que haja um acúmulo muito grande de ações sobre poucas pessoas. Embora a presidente convoque com frequência os cooperativados para realizar ações referentes ao gerenciamento da Cooperativa, ela não tem obtido o retorno necessário por parte dos mesmos.

Os cooperativados realizam suas atividades no campo, ficando envolvidos exclusivamente com este tipo de trabalho. Outras atividades relacionadas à Cooperativa e à sua gestão administrativo-financeira são negligenciadas. A manutenção dos equipamentos; a conservação do prédio da Cooperativa; a comercialização da polpa; a expansão de mercado e a obtenção de recursos financeiros, são ações com as quais os cooperativados não se comprometem e nem assumem responsabilidade, por se tratarem de atividades extracampo.

Além disso, os cooperativados não se envolvem com quaisquer atividades fora do período da safra e nem com as que não representem lucro imediato, o que sobrecarrega a senhora Franciani, a presidente da Cooperativa.

Vale lembrar que em grande parte do estado do Amazonas, a sociedade civil assume uma postura passiva em consequência da atitude assistencialista do estado. Daí a maioria das pessoas da região acreditarem que todas as necessidades da população devem ser providas pelo poder público. Deste modo, cria-se uma acomodação na sociedade, isentando as pessoas de suas responsabilidades como cidadãs. Esse problema antigo e habitual impregnou o cotidiano dos amazonenses, ou seja, um comportamento que valoriza o assistencialismo e torna difícil o discernimento de até onde é jurisdição governamental e até onde é competência da sociedade civil.

Esta postura passiva também está atrelada à formação urbanística do estado do Amazonas, questão que foi abordada no capítulo 3.

Um problema de âmbito administrativo-financeiro que afeta indiretamente a comercialização da polpa, é a falta de renovação do selo orgânico emitido pelo Ministério da Agricultura. Por conta deste motivo, alguns compradores buscaram 
outros fornecedores, e a Cooperativa tem dificuldade em conquistar novos clientes.

As dificuldades da Cooperativa seguem com as máquinas quebradas e em estado de má conservação; a despolpadeira industrial, máquina fundamental para o beneficiamento da polpa, não está operando e foi substituída por uma despolpadeira semi-industrial; a câmara frigorífica necessita de manutenção na peça que mantém a sala resfriada; a plataforma motorizada sobre trilhos para o transporte de açaí continua desativada; o caminhão funciona, mas em condições precárias; o contêiner com ferrugem e uma peça da máquina de refrigeração quebrada não cumpre suas funções.

Com relação à instalação do prédio, a senhora Franciani comentou que a Cooperativa trabalha com o fornecimento de energia bloqueado; uma vez que no período da safra, a conta da energia é quitada, mas em seguida é acumulado um novo débito. Desse modo, a Cooperativa vai trabalhando da seguinte forma: paga seis meses pelo fornecimento de energia, e em seguida fica devendo seis meses de energia.

De acordo a senhora Franciani, a estagnação total das atividades produtivas na cooperativa, durante a entressafra, é uma questão bastante preocupante. A atividade produtiva da Cooperativa nos primeiros meses do ano (janeiro até junho), não pode ser seguida por um período de paralisação total, com o prédio totalmente fechado e inativo.

A Cooperativa paralisada por seis meses é um grande problema, somado ao acúmulo de sementes, decorrente dos meses de safra, para o qual não existe manejo adequado. Uma parte das sementes é utilizada como adubo, porém a demanda é menor do que o acúmulo, ou seja, a formação residual é contínua e acumulativa durante a safra e aumenta de um semestre para o outro, chegando ao ano seguinte com alto nível de resíduo.

Um fato novo na cidade de Codajás é a instalação de uma nova indústria de beneficiamento da polpa de açaí. Esta indústria, na apreciação da senhora Franciani, representa uma ameaça para a Cooperativa. O proprietário comentou na cidade que iria comprar toda a produção de açaí por um valor acima do valor comercializado na Cooperativa. Outra ameaça é a experiência do empresário e seu poder de articulação frente a outros grandes centros consumidores, como por exemplo, as cidades de Manaus e de Belém.

As soluções de âmbito administrativo-financeiro demandam gestão operacional e recursos financeiros. De certo modo, existe uma ligação entre as soluções dos problemas, pois na medida em que um ponto é solucionado, outros 
pontos também são reparados. Por exemplo, se houver a manutenção das máquinas, haverá maior produtividade, e consequentemente maior rentabilidade para a Cooperativa.

\section{- Problemas no âmbito cultural}

Um problema no âmbito cultural, na visão da presidente da Cooperativa, é a falta de interesse dos jovens pela atividade agrícola, o que os faz deixar o município em busca de algo que ofereça uma atividade menos rústica. Ela comenta que a preferência dos jovens é por trabalhos com o uso de computadores. A tecnologia, de modo geral, vem atraindo não só os jovens de Codajás, mas também os jovens de todo o mundo. O problema é que as atividades oferecidas no município de Codajás estão distantes dos interesses dos jovens.

Contudo, um atrativo oferecido aos jovens é a Festa Cultural do Açaí. Atualmente, a Festa é divulgada no estado do Amazonas, conseguindo atrair apenas os moradores de Codajás e pessoas dos arredores. Entretanto, a festa apresenta um potencial de expansão que pode ser direcionado para o contexto do turismo rural ou ecoturismo, nos moldes de ações endógenas que priorizam e valorizam a cultura local como também respeitam as fragilidades do município. Neste sentido, a finalidade é aproximar turistas e a classe empresarial, para que vislumbrem o desenvolvimento social, econômico e cultural de Codajás, por meio do turismo cultural.

Assim, ressaltar as manifestações folclóricas da região Amazônica durante a Festa do Açaí, significa valorizar e manter uma cultura transmitida por gerações. Outro modo de valoração cultural é promover cursos destinados aos jovens e aos cooperativados, destacando a relevância das atividades produtivas do açaí. Nesses cursos, atenção especial deveria ser dada ao conceito de "envolvimento sustentável", expressão utilizada por Viana (199. p. 3), em que é necessário o envolvimento das sociedades com os ecossistemas locais, para fortalecer e expandir os seus laços sociais, econômicos, culturais, espirituais e ecológicos, e deste modo obter a sustentabilidade em todas essas dimensões.

A partir deste envolvimento com os ecossistemas locais, os jovens podem perceber seu papel no modelo produtivo do açaí e assumir uma postura de identidade com $\mathrm{o}$ ambiente, e consequentemente adotem responsabilidades $\mathrm{e}$ empoderamento político para as decisões sociais, econômicas e culturais, desvinculando-se do assistencialismo do governo. 
A abordagem dos cursos pode proporcionar aos jovens a base para uma tomada de consciência, reorientando-os para as atividades agrícolas e as atividades locais. Acredita-se que os cursos possam aumentar a motivação dos cooperativados para ter um envolvimento maior com a Cooperativa de Açaí de Codajás.

\section{- Problemas no âmbito técnico}

Por fim, no âmbito técnico são tratados problemas e soluções que possam otimizar o modelo produtivo do açaí, apontando intervenções que buscam trazer melhores condições de trabalho e qualidade de vida para o extrativista.

Como designer, entendo que os artefatos concentram esforços para solucionar um objetivo pontual, mas as melhorias advindas do uso desses artefatos se estendem para outras áreas que correspondem ao bem-estar, à qualidade de vida e ao conforto. Neste sentido, a nossa finalidade é conseguir avanços técnicos para otimizar as atividades de escalada no açaizeiro, de debulhamento dos cachos e de acúmulo das sementes, e com isso esperamos que os benefícios se estendam para os processos nos âmbitos administrativofinanceiro e cultural.

A escalada no açaizeiro e o debulhamento dos cachos, além de perigosos e insalubres, provocam lentidão no processo produtivo do açaí, o que compromete a qualidade do fruto e, também, a produtividade. Atualmente, a forma como as atividades estão sendo realizadas traz como consequência fragilidades tanto para o processo produtivo, quanto para a saúde do extrativista.

O modelo produtivo do açaí em Codajás, como já foi mencionado, apresenta um conjunto de problemas interligados. Daí suas soluções também, estarem direta ou indiretamente ligadas.

A seguir buscamos delimitar todos os problemas da Cooperativa que foram mencionados e articula-los a possibilidades de solução, apontando alguns caminhos para a otimização dos mesmos.

\section{Síntese dos problemas e estratégias para contorná-los}

\section{- Administrativo-financeiros}

1. Concentração de atividades na figura do presidente da Cooperativa conscientização dos cooperativados de que a responsabilidade com a Cooperativa é de todos, que este trabalho é coletivo; 
2. Comportamento passivo dos cooperativados por conta de atitude assistencialista do estado - participação dos cooperativados em cursos motivacionais;

3. Comercialização da polpa do açaí sem o selo orgânico emitido pelo Ministério da Agricultura - obtenção de recursos financeiros para aumentar o lucro, investir em infraestrutura e procedimentos para reaver o selo emitido pelo Ministério da Agricultura;

4. Máquinas e equipamentos quebrados e/ou necessitando manutenção - as soluções ocorrerão com recursos advindos da solução listada no item 3.

4.1 Manutenção da sala da câmara frigorífica.

4.2 Reativação da plataforma motorizada sobre trilhos.

4.3 Conservação do caminhão.

4.4 Conservação/manutenção do contêiner com ferrugem e da máquina de refrigeração;

5. Fornecimento de energia bloqueado no prédio da Cooperativa - obtenção de outras fontes de recurso e a não interrupção das atividades durante a entressafra; 6. Revitalização das atividades da cooperativa na entressafra - proposta de investimento em turismo rural com a prática do arvorismo, além de atividades culturais realizadas nos plantios do açaizeiro (este item será discutido adiante);

7. Acúmulo de sementes sem manejo adequado - aproveitamento das sementes na pavimentação de calçadas e na produção de painéis construtivos. Os painéis serão utilizados na construção de um complexo turístico (este item será discutido adiante);

8. Instalação de uma nova indústria concorrente de beneficiamento da polpa de açaí - as propostas em andamento fortalecem a Cooperativa, trazendo lucro e recursos para enfrentar a concorrência.

É possível perceber que realizando otimizações técnicas pontuais na escalada, no debulhamento e no acúmulo de sementes teremos benefícios para os setores administrativo-financeiro e cultural da Cooperativa. Acreditamos que as melhorias implementadas no modelo produtivo do açaí podem ser reaplicadas em outros municípios e localidades do estado, prospectando o desenvolvimento do Amazonas.

\section{- Sociais e culturais}

1. Falta de interesse dos jovens pela atividade rural (agrícola) - construção de um complexo turístico rural; 
2. Festa Cultural do Açaí com pouca repercussão - exploração do potencial da Festa com uma proposta de turismo cultural, com exposições itinerantes, apresentações de artistas locais e apresentações de filmes educativos;

3. Inexistência de cursos técnicos e motivacionais direcionados para os jovens oferecimento de cursos e dinâmicas relacionados ao contexto rural e à realidade do modelo produtivo de Codajás.

\section{- Técnicos}

1. Escalada do açaizeiro - construção de uma escada, e prática do arvorismo para subir e descer com os cachos do açaizeiro;

2. Debulhamento dos cachos - desenvolvimento de um equipamento para facilitar a retirada dos frutos das ráquilas;

3. Acúmulo de sementes - montagem de uma oficina com dois ambientes para o aproveitamento de sementes: um para a pavimentação de calçadas e outro para a produção de painéis com as fibras das sementes.

Para resolver este conjunto de problemas, buscamos uma proposta que atendesse, simultaneamente, a todos os problemas ou à maioria deles. Partindo desse pressuposto, desenvolvemos três elementos: uma estrutura para um complexo turístico rural conjugado com o turismo cultural; um debulhador; e uma oficina para o aproveitamento de sementes.

Portanto, é relevante revisitar o turismo rural como uma prática que valoriza as atividades do campo, o seu modo de vida, e o meio ambiente. Conforme Elesbão (2014. p.1), o turismo rural representa uma estratégia para o desenvolvimento local com delineamento sustentável, que possibilita a dinâmica dos espaços rurais, preservação da natureza e o surgimento de novos postos de trabalho. Dentre as várias atividades empreendidas pelo turismo rural, o arvorismo reúne características que se adaptam à realidade de Codajás. Tal atividade se apresenta como uma possível solução no que tange à escalada do açaizeiro e à coleta dos cachos com segurança, ao mesmo tempo em que se configura como uma prática esportiva que interessa aos jovens e atrai pessoas dos arredores, motivando a economia local.

Neste sentido, apontamos o turismo rural somado ao turismo cultural, formando um complexo turístico rural e cultural, como uma das propostas para solucionar vários problemas da Cooperativa.

A proposta de empreendimento de um complexo turístico rural e cultural compreende a atividade de arvorismo e um espaço cultural. $O$ arvorismo 
proporcionará aos extrativistas a escalada no açaizeiro e coleta dos cachos com segurança no período da safra, assim como poderá ser explorado como uma prática esportiva, promovida pelo turismo rural durante a entressafra, período em que as atividades da Cooperativa atualmente ficam paralisadas. O espaço cultural, composto de um ambiente adaptado, promoverá cursos e eventos artísticos.

Uma outra proposta é a de desenvolvimento de um equipamento que agilize a tarefa de debulhar os frutos do cacho. Nesse contexto, adotaremos a abordagem projetual de tecnologia apropriada, envolvendo a comunidade na solução do problema e na implementação de processo simplificado, com aproveitamento de material.

Por fim, o último elemento apresentado como solução para os problemas da Cooperativa compreende uma oficina para o aproveitamento de sementes de açaí, com base em fundamentos da tecnologia apropriada. Todos estes três itens serão discutidos separadamente.

Portanto, nossa proposta para a Cooperativa se configura em três ações: Complexo turístico rural e cultural; equipamento para debulhar os cachos; e oficina para o aproveitamento de sementes.

A seguir apresentamos um estudo de alternativas para o modelo conceitual para a produção do açaí no Estado do Amazonas e um levantamento e análise de propostas para a definição das soluções.

\section{3}

Desenvolvimento do modelo conceitual para a produção do açaí

As alternativas para a configuração do modelo conceitual para a produção do açaí foram definidas com base no Organograma elaborado para a Cooperativa de Açaí de Codajás, incluindo os problemas identificados e as estratégias de solução imaginadas (Figura 75). 


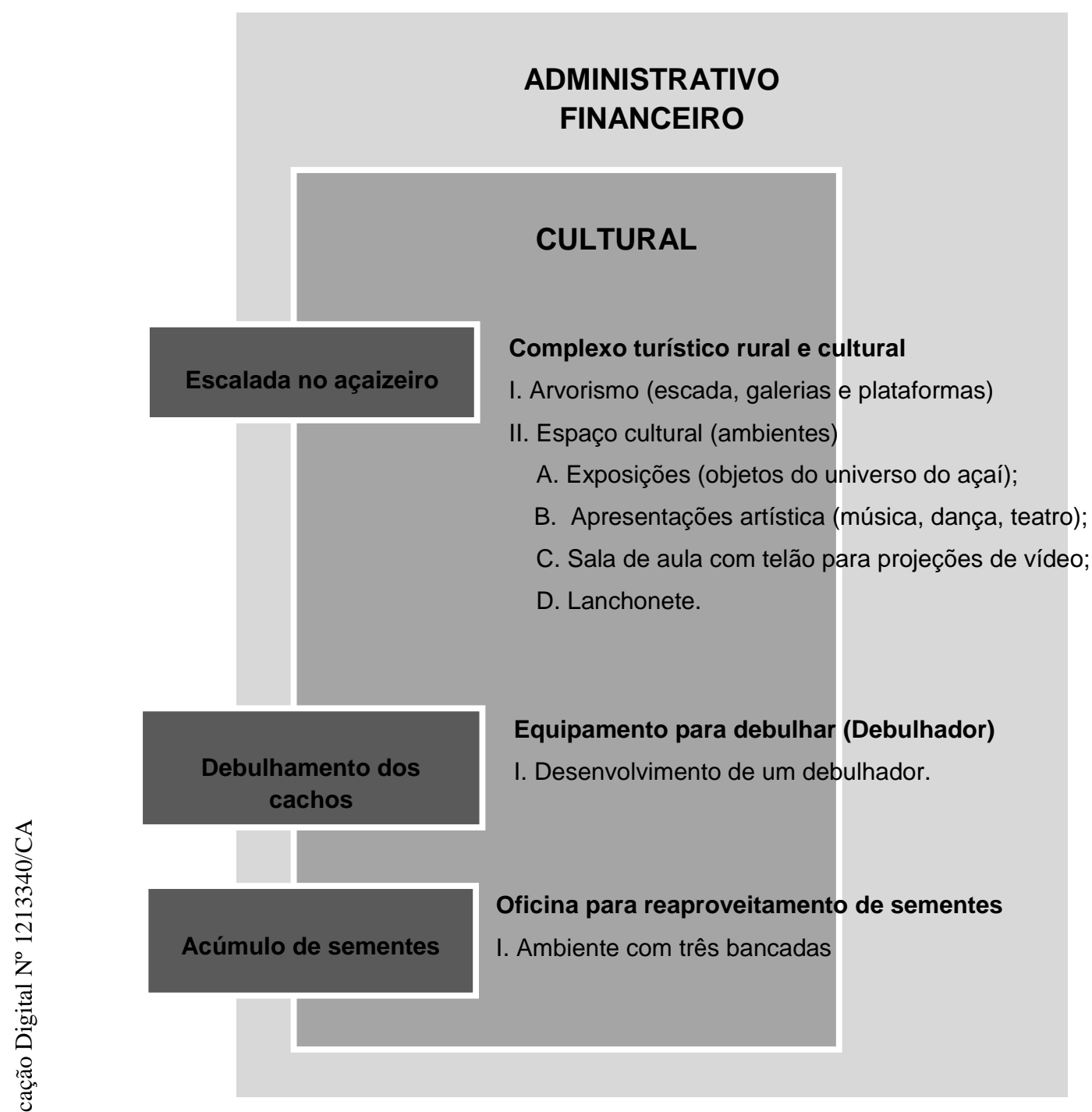

Figura 75 - Organograma para a Cooperativa de açaí de Codajás, com os problemas identificados e estratégias de solução.

\subsection{1}

\section{Proposta para a colheita do açaí}

Ao abordarmos a atividade da colheita do açaí, ressaltamos a periculosidade da escalada na palmeira, que é realizada apenas com a peconha. Segundo Homma et al. (2009. p. 5), existem relatos dos agricultores a respeito dos casos de acidentes graves e fatais ocorridos durante essa prática.

A partir de um estudo aprofundado da questão, identificamos e apresentamos 4 alternativas de artefatos e equipamentos para utilização na escalada das palmeiras e colheita do açaí, priorizando a segurança do escalador e promovendo o aumento da retirada de cachos nos açaizeiros. 
A seguir serão apresentadas alternativas coletadas na literatura e comentadas.

\section{- Primeira alternativa:}

O primeiro equipamento é um dispositivo rústico para colheita do açaí (Figura 76). Segundo Homma (2006. p. 12), o artefato é feito de madeira e em sua extremidade há uma peça de vergalhão de ferro que retira o cacho da palmeira.

Os equipamentos mostrados nas fotos são de autoria do Sr. Dorival Costa Carvalho, que mora no Município de Marabá - PA. As versões do equipamento, com variações no sistema de corte e no emprego de materiais, ilustram bem o saber técnico local.

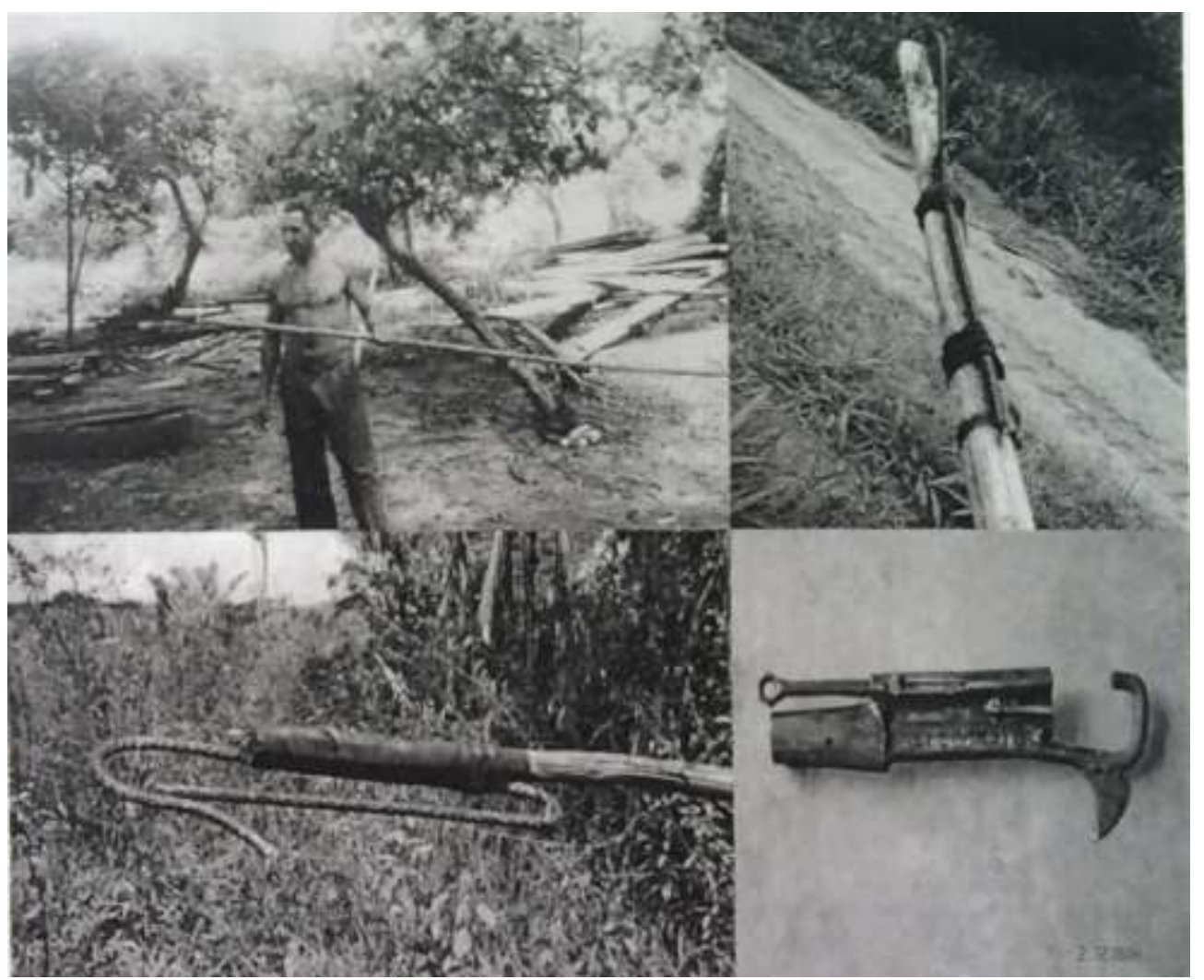

Figura 76 - Coletor de cacho de açaí feito de madeira com suas variações no sistema de corte. Homma (2006. p. 12).

\section{- Segunda alternativa}

O segundo equipamento é o protótipo de "tiradeira" de açaí (Figura 77). O equipamento consta no Relatório de Atividades feito pela Fundação Amazonas Sustentável - FAS (2014. p. 80). A FAS executou um projeto para a cadeia produtiva do açaí que resultou neste protótipo. Um dispositivo que é fixado no açaizeiro e deslizado na palmeira por meio de um sistema de roldanas que possui 
uma guilhotina que faz o corte do cacho, e, em seguida, o mesmo é preso por cordas que descem até o solo.

Tal equipamento apresenta vantagens, uma vez que reduz os esforços físicos; evita a escalada da palmeira, consequentemente proporcionando segurança; e aumenta a retirada de cachos. Existem, porém, aspectos complicadores neste protótipo, como a dificuldade de fixação do equipamento no açaizeiro, somada à ineficácia da guilhotina no corte.

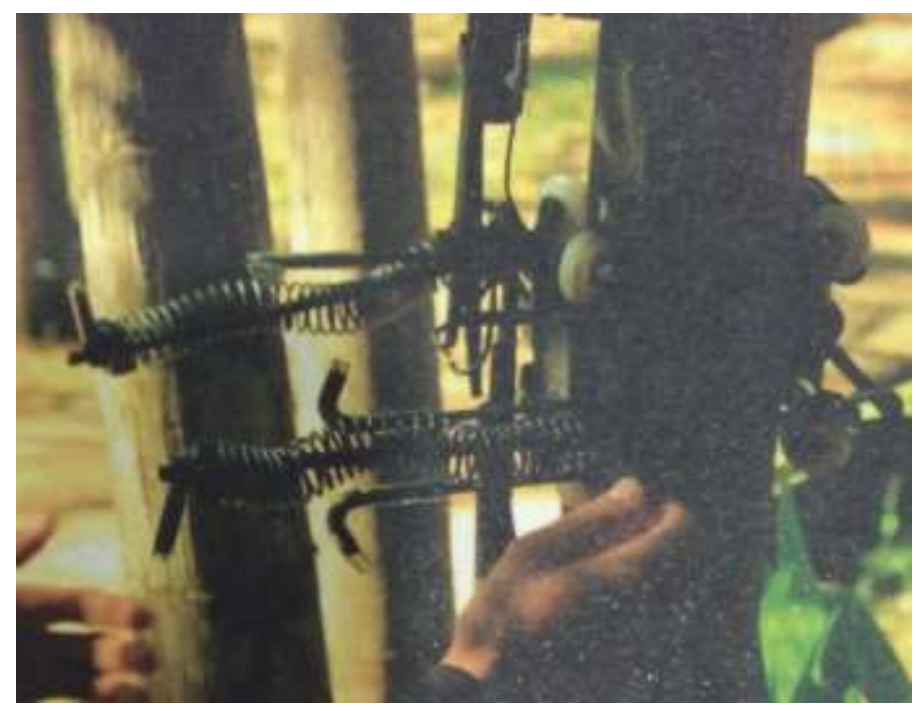

Figura 77 - Protótipo de "tiradeira" de açaí.

Fonte - Relatório de atividades da Fundação Amazonas Sustentável - FAS de 2014.

\section{- Terceira alternativa}

O terceiro equipamento identificado incide em uma proposta conceitual em registro de patente. Em Relatório Descritivo de Patente de Invenção, o equipamento é definido como: "Equipamento e Métodos para a Colheita de Cachos de Frutas" (PI 0803992-5) (Figura 78). No relatório, o equipamento é apresentado como uma ferramenta para colheita de cachos de frutas, em geral. $O$ equipamento consiste em uma vara de alumínio de tamanho regulável até aproximadamente 12 metros de comprimento. Na sua extremidade superior, existem um sistema de corte do cacho, um receptáculo móvel para receber o cacho e roldanas que permitem a descida deste receptáculo.

Este equipamento oferece vantagens tanto para a qualidade do fruto, quanto para a segurança do escalador. No âmbito da qualidade do fruto, podem ser mencionadas duas atividades: o corte seletivo do cacho e a sua descida controlada, evitando o seu contato com o solo. Desta forma, impede-se a contaminação com os resíduos existentes no solo e permite-se que os frutos permaneçam nas ráquilas e não se espalhem no solo, havendo portanto um maior 
aproveitamento dos frutos. Outra vantagem é o aumento da retirada de cachos, o que significa maior produtividade sem riscos para o coletor.

Quanto à segurança, o equipamento evita a escalada da palmeira e o contato direto com instrumentos cortantes. Este equipamento exerce a função de um EPI. Outro item favorável é a viabilidade técnica de baixa complexidade e facilidade de uso.
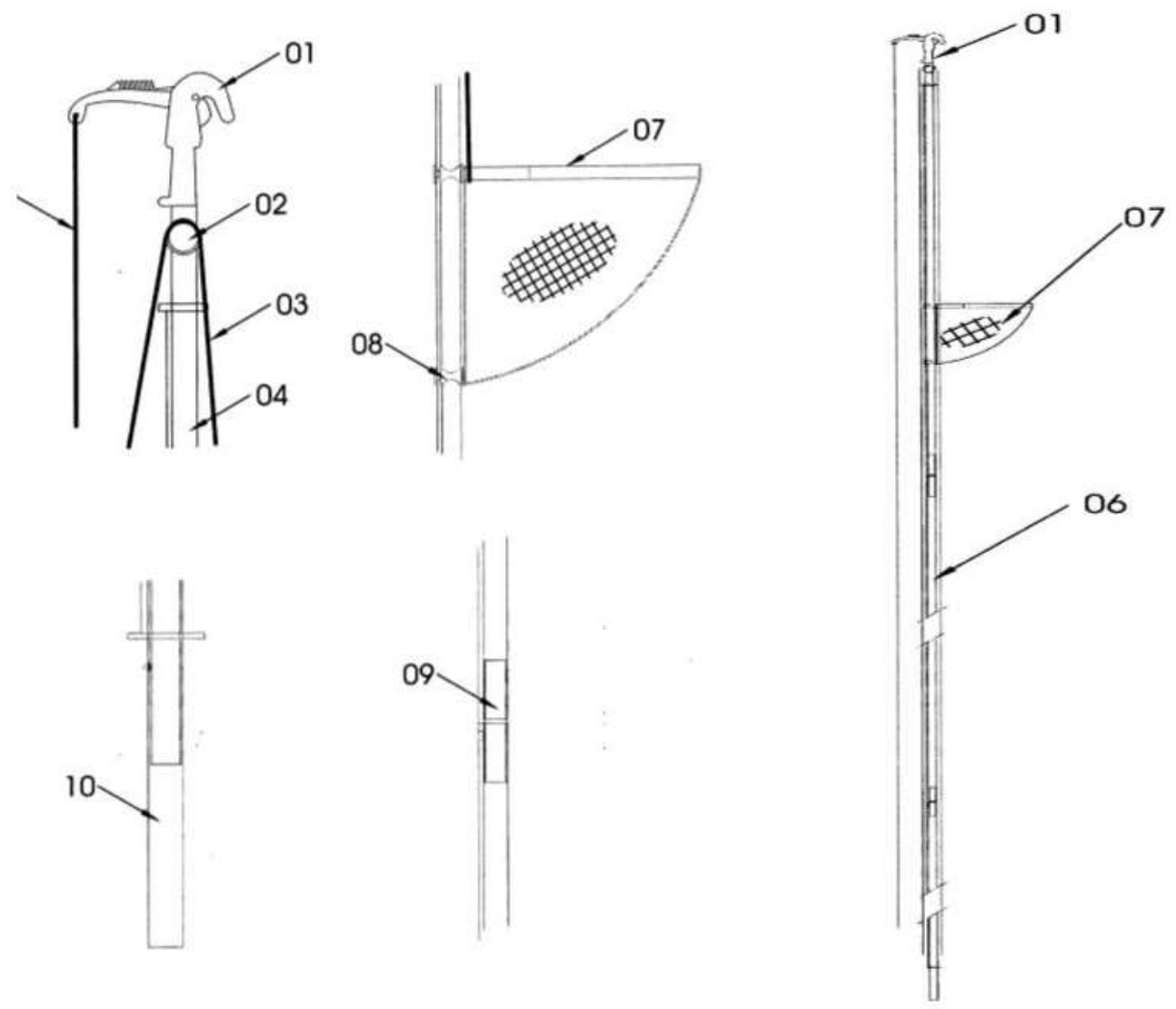

Figura 78 - Equipamento e Métodos para a Colheita de Cachos de Frutas.

Fonte - Relatório descritivo de Patente de invenção (PI 0803992-5).

Dos três equipamentos pesquisados e analisados, o "Equipamento e Métodos para a Colheita de Cachos de Frutas" (PI 0803992-5) apresenta indícios de maior eficiência, garantindo segurança para a pessoa que vai retirar o cacho. Proporciona facilidade de manejo e uso, oferece eficiência no corte do cacho e, por fim, recolhe o cacho até o solo com menor perda de frutos. Este equipamento evita a escalada das palmeiras do açaí, solucionando tecnicamente um problema da comunidade extrativista do açaí.

\section{- Proposta para a colheita dos cachos}

Porém, nossa proposta buscou uma outra forma de aproximação da questão. Não apresentamos o desenvolvimento de um equipamento para a 
colheita dos cachos de açaí, mas sim uma proposta alternativa para evitar a escalada no açaizeiro e promover a coleta com segurança: o arvorismo.

O arvorismo é um esporte radical que consiste na travessia entre plataformas montadas no alto das árvores, ultrapassando diferentes tipos de obstáculos como escadas e pontes suspensas. O arvorismo vem sendo utilizado para lazer, recreação e estudos de fauna e flora. Nele pontes suspensas são construídas nas copas das árvores, sem danificá-las, tendo o cuidado de preservar o meio ambiente. Em nossa proposta pensamos ampliar a utilização do arvorismo para a atividade extrativista do açaí. Desta forma, propomos a construção de uma estrutura para a prática do arvorismo no açaizal que ficará montada permanentemente, servindo para a colheita do açaí pelo extrativista no período da safra, e para o turismo rural, como elemento do complexo turístico rural e cultural, durante a entressafra.

A ideia de trazer o complexo turístico rural e cultural como proposta para compor o modelo conceitual para a produção do açaí está fundamentada no design sustentável e no turismo rural, temas que foram tratados nos capítulos 2 e 3 , respectivamente.

No contexto do design sustentável, Margolin (2014. p. 133) identifica a expansão do ecoturismo e do turismo cultural como práticas bem-vindas. Temas atualmente em evidência, que aproximam a economia e o meio-ambiente.

Já na opinião de Elesbão et al. (2014. p. 1), o turismo rural significa uma estratégia de desenvolvimento local que favorece a conservação ambiental. $O$ autor aponta como benefícios do turismo rural a dinamização do espaço rural e o surgimento de novos postos de trabalho. Neste sentido, dinamizar o espaço rural representa implementar uma atividade na entressafra, um período inativo no açaizal, que pode ser transformado pela nova atividade, com demanda de novos empregos.

No caso específico de Codajás, a proposta de um complexo turístico rural e cultural compreende não só o arvorismo como também a criação de um espaço cultural e a ampliação do potencial da Festa Cultural do Açaí. Neste sentido, o arvorismo buscará contornar três problemas: a escalada do açaizeiro, a colheita do açaí e a estagnação das atividades durante a entressafra.

Como descrito anteriormente nesta pesquisa, na colheita os extrativistas sobem no açaizeiro com uma peconha e uma faca. Eles escalam de quinze a trinta açaizeiros por dia, e esta quantidade pode aumentar dependendo da maturação do fruto. 
Algumas vezes, os extrativistas sobem e descem sem nenhuma retirada de cacho, isso porque o fruto, quando observado do solo, muitas vezes é visto como maduro, mas ao se aproximar do fruto, verifica-se que ele ainda não está totalmente apropriado para o consumo. É importante dizer que o fruto do açaí não amadurece fora da palmeira. Fora da palmeira ele se estraga. Então, muitas vezes o extrativista realiza a subida na palmeira em vão, ou seja, ele sobe e desce sem nenhum cacho, o que significa um grande esforço físico e tempo desperdiçado. Além da periculosidade de subir no açaizeiro, é também incerta para o extrativista a existência de cachos maduros.

Isso porque a altura das palmeiras, de aproximadamente doze a vinte metros de altura, é um elemento complicador e um desafio para se encontrar maneiras de escalar com segurança, considerando ainda como pontos críticos a subida e a descida do extrativista, assim como a descida dos cachos de açaí. Neste sentido, deve ser levado em conta que os extrativistas disponibilizam de poucos recursos financeiros, técnicos e materiais.

Nossa proposta prevê a montagem de uma estrutura permanente que atenda aos períodos de safra e de entressafra. Como hoje na entressafra as atividades extrativistas ficam paralisadas, seria interessante fazer uso da estrutura para atividades lúdicas, educativas, esportivas e rentáveis para a Cooperativa. Por isso apresentamos uma alternativa de arvorismo combinado com uma escada. A estrutura será construída com painéis produzidos com as sementes de açaí, que serão detalhados mais adiante, e terá duas finalidades: facilitar o acesso aos cachos das palmeiras na atividade extrativista e permitir a prática esportiva, que atrai pessoas para o turismo.

O arvorismo, como alternativa de otimização, compreende plataformas nos açaizeiros e passarelas que permitem acesso entre as palmeiras. $O$ extrativista alcançará o alto da palmeira por meio da escada, se instalará na plataforma, cortará o cacho de açaí e o descerá por meio de uma corda. Em seguida, atravessará a passarela até uma outra plataforma e realizará a retirada de outro cacho. Esta atividade pode ser realizada com segurança e mais agilidade.

O arvorismo favorece a segurança e a saúde do extrativista, reduzindo seu esforço físico e o tempo necessário para acessar os cachos de açaí. Desta forma, permite a retirada de um maior número de cachos por açaizeiro, resultando em uma melhoria na produtividade da colheita do açaí. Além disso, a prática esportiva do arvorismo será uma das atividades do complexo turístico rural e cultural que será complementada com a programação disponível do espaço 
cultural. Assim, o arvorismo terá um uso intenso tanto durante a safra, como na entressafra.

A estrutura deste arvorismo é constituída por plataformas em cada açaizeiro; passarelas com guarda-corpo; sistema de roldanas para descer o cacho; e escada de acesso à plataforma. A estrutura será toda construída com painéis produzidos a partir do aproveitamento das sementes do açaí.

Inicialmente foram pensados dois tipos de escada para serem empregados neste projeto de arvorismo: escada tradicional e escada em espiral. A escada tradicional propõe um processo construtivo simples e bastante conhecido que dispensa orientação de montagem. A escada em espiral exige um sistema construtivo especial, encontrado na literatura, que necessitará uma avaliação técnica para verificação de sua viabilidade no açaizal e/ou alternativas construtivas. A proposta de escada em espiral seria montada em torno da estirpe do açaizeiro, utilizando um sistema modular que fixa cada degrau sem danificar ou marcar a árvore (Figura 79).

A relevância desta escada está na possibilidade, tanto dos extrativistas quanto dos turistas e esportistas, de subir e descer com segurança.

As Figuras 80 e 81 mostram o processo regular de montagem da escada em espiral. A montagem compreende várias etapas: a primeira é a colocação de fitas em torno da árvore (Figura 79). A segunda etapa é a fixação dos degraus na fita (Figura 80). Por fim, a escada em espiral finalizada (Figura 81). No caso de montagem no açaizal as devidas adequações e adaptações devem ser analisadas.

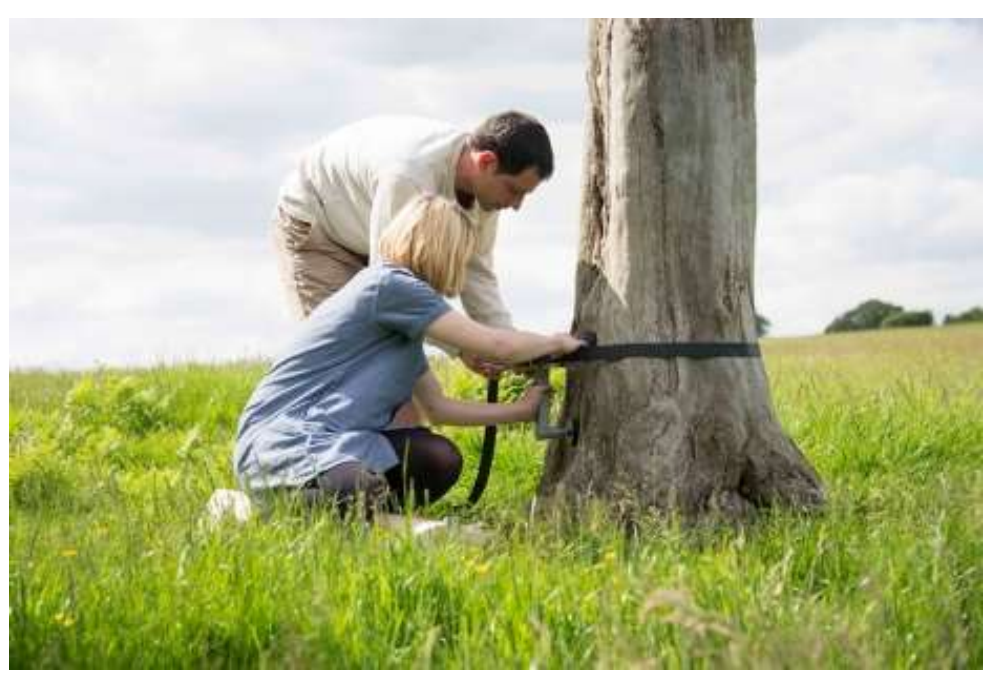

Figura 79 - Primeira etapa do sistema de escada em espiral. Colocação de fita.

Fonte: http://www.boredpanda.com/canopy-tree-stairs-thor-ter-kulve-robert-mcintyre-canopystair/ 


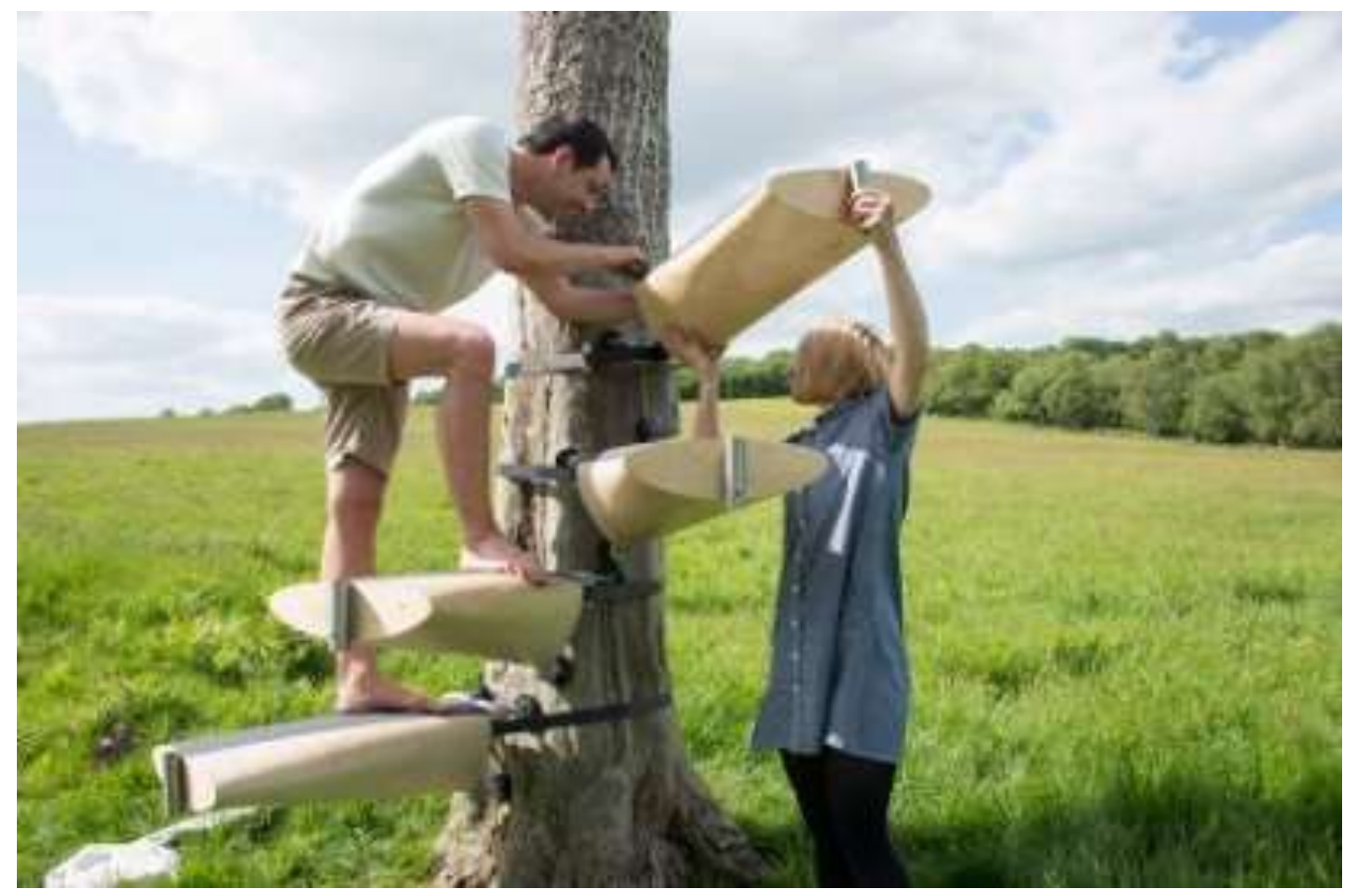

Figura 80 - Segunda etapa do sistema de escada em espiral. Fixação do degrau.

Fonte: http://www.boredpanda.com/canopy-tree-stairs-thor-ter-kulve-robert-mcintyre-canopystair/

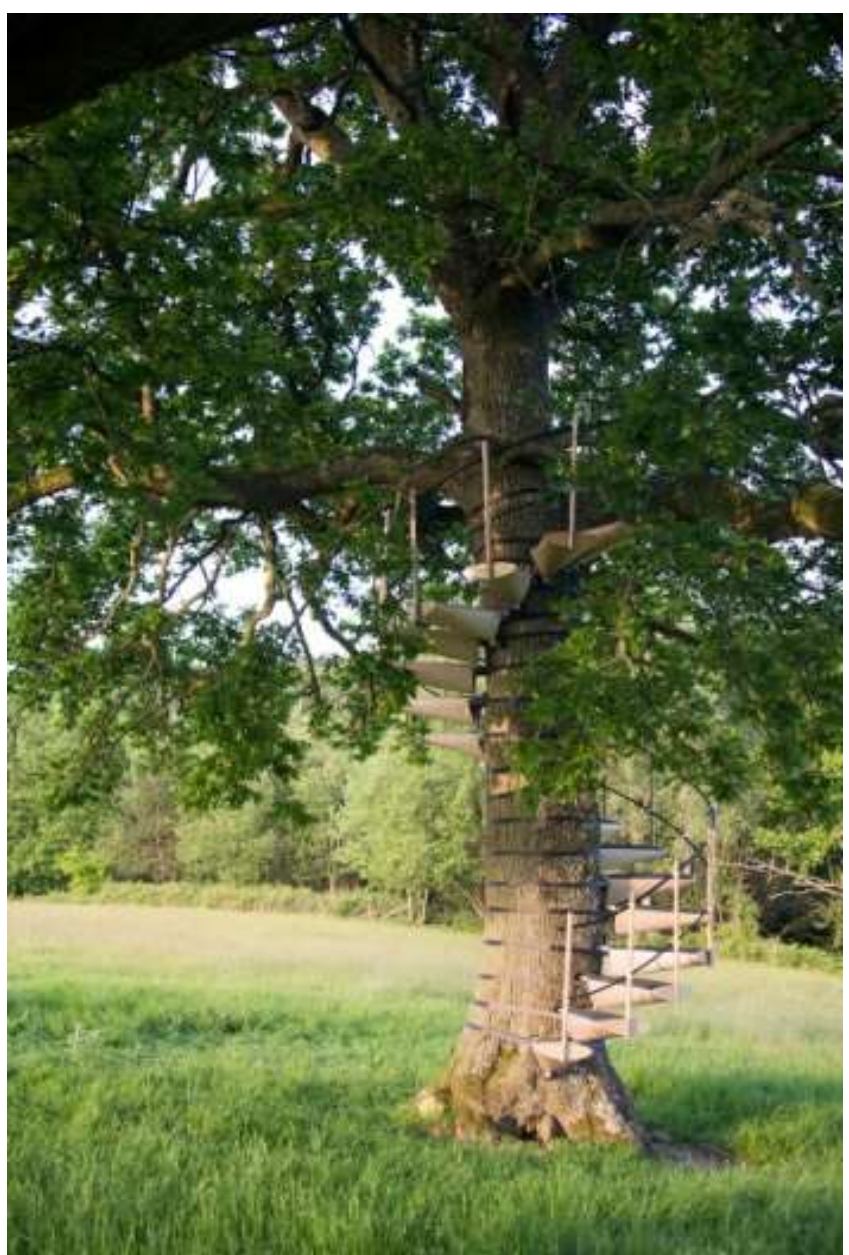

Figura 81 - Sistema de escada em espiral finalizado.

Fonte: http://www.boredpanda.com/canopy-tree-stairs-thor-ter-kulve-robert-mcintyre-canopystair/ 
De acordo com o organograma (Figura 75), o arvorismo é apresentado como primeiro item do complexo turístico rural e cultural. Em seguida temos o espaço cultural com seus respectivos ambientes.

A instalação do espaço cultural parte da premissa da observação do entorno e do resgate dos costumes e da arquitetura local.

Existe uma casa de palafita, próxima ao açaizal visitado, que será adaptada para abrigar o espaço cultural. Os ambientes internos devem ser versáteis e para tanto serão distribuídos e/ou remanejados utilizando-se paredes divisórias produzidas com painéis de sementes de açaí.

O espaço cultural prevê três ambientes com finalidades distintas: ambiente de sala de aula e adaptável para projeções de vídeo e filmes educativos; ambiente para exposição e adaptável para apresentações artísticas (música, dança, teatro); por fim, ambiente de lanchonete.

O ambiente de sala de aula abrigará os cursos técnicos e motivacionais a respeito do meio ambiente e do universo do açaí, e servirá também como sala de projeção de filmes educativos. O ambiente de exposições deve possuir uma estrutura versátil, para exibições temporárias, que seja adequada para a exposição de objetos e materiais do universo do açaí, como também para a exposição de materiais relacionados a outros temas. Este ambiente pode ser adaptável para apresentações artísticas, buscando promover artistas locais e receber artistas nacionais, dinamizando o cenário cultural de Codajás. Por fim, uma área será dedicada à instalação de uma lanchonete, preparada para oferecer lanches e refeições rápidas.

A opção de adaptação de uma construção feita em sistema de palafita, para abrigar o espaço cultural, valoriza e preserva a história e a cultura das comunidades ribeirinhas.

O arvorismo e o espaço cultural farão parte de um complexo turístico rural e cultural. A proposta pretende favorecer a colheita do açaí durante o período da safra e dinamizar a região no período da entressafra, com o turismo rural.

Acredita-se que o complexo turístico rural e cultural seja uma alternativa de geração de trabalho no campo e possa despertar o interesse dos jovens de Codajás e assim diminuir, em um primeiro momento, a evasão de jovens do município. Em um segundo momento, pretende-se estender esse interesse para as atividades produtivas do açaí. Neste sentido, a solução imaginada para um problema técnico acaba sendo também adequada a dois problemas de natureza cultural, que são o não envolvimento dos Cooperativados no período da entressafra e o desinteresse dos jovens. 
Acreditamos, ainda, que a proposta de incorporação da Festa Cultural do Açaí na programação do complexo turístico rural e cultural, integrando as atividades do arvorismo e do espaço cultural com a finalidade de expandir e divulgar a Festa para que ela possa ser melhor aproveitada, promoverá atividades atrativas para os jovens de Codajás.

\section{3 .2}

\section{Proposta para o Debulhamento}

O debulhamento do açaí em Codajás, assim como a colheita, é realizado na maior parte das vezes sem o emprego de EPIs. A atividade consiste na remoção dos frutos das ráquilas, feita manualmente. Uma ação que machuca as mãos e demanda tempo para a sua efetivação. Alguns extrativistas fazem uso de luvas, outros resistem com a justificativa de perda da sensibilidade.

A atividade de debulhar se caracteriza como uma atividade morosa e rústica. A morosidade é decorrente do debulhamento ser manual, sem equipamento de proteção nem equipamento de auxílio à tarefa, outra questão é ser debulhado uma ráquila por vez. O modo operacional do debulhamento em Codajás, atualmente é realizado de forma desfavorável tanto para o extrativista quanto para a atividade em si.

A seguir apresentamos uma alternativa encontrada na literatura empregada no Estado do Pará e desconhecida pela Sra. Franciani.

\section{- Primeira alternativa:}

Em substituição às luvas, foi criado um debulhador (pente) (Figura 82) para a retirada dos frutos das ráquilas (Figura 83). 


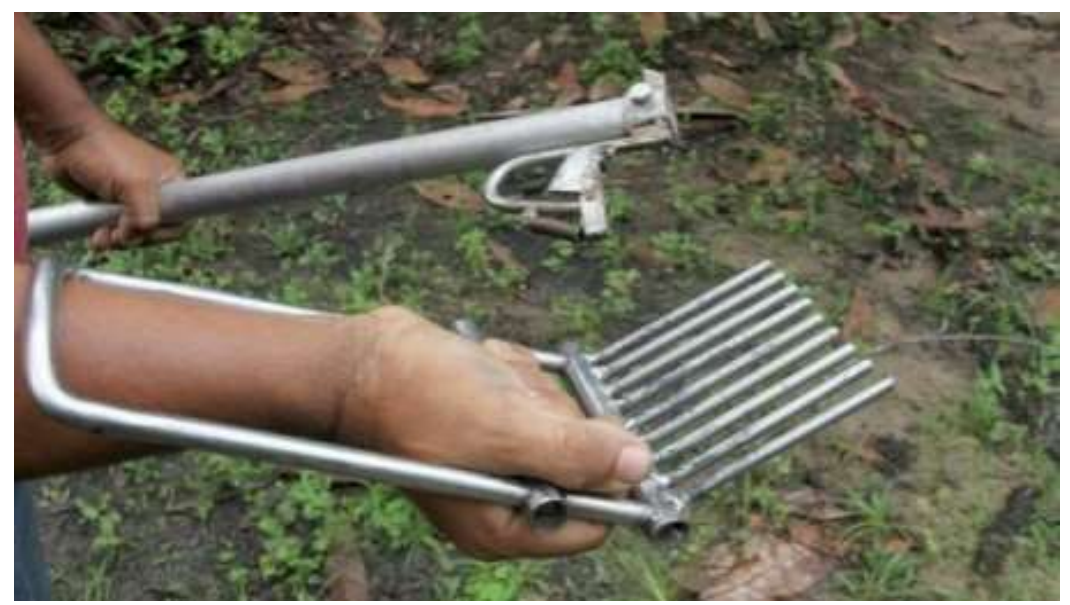

Figura 82 - Debulhador (pente) para a remoção dos frutos das ráquilas.

Fonte: Portal Amazônia http://portalamazonia.com/noticias-detalhe/ciencia-e-tecnologia/agricultordo-para-inventa-apanhador-de-acai-que-substitui-

peconha/?cHash=edc277370cf65a465d3dec96d6b16527

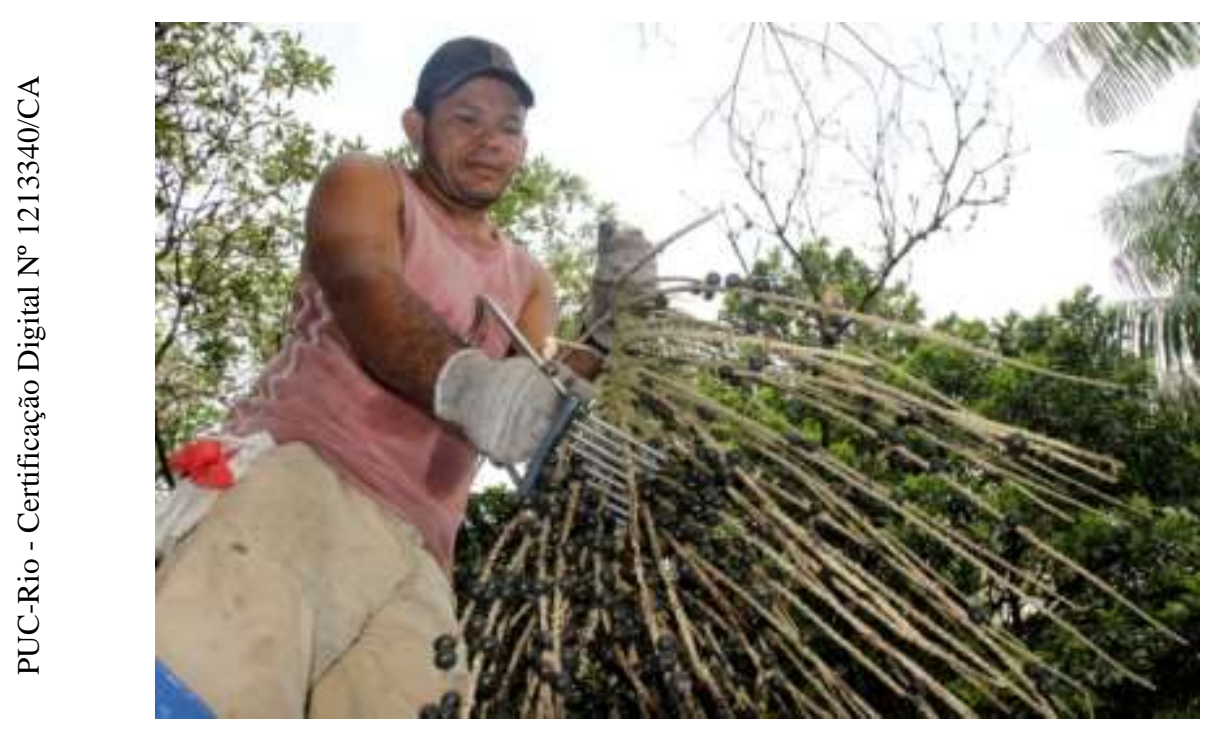

Figura 83 - Remoção dos frutos das ráquilas com o auxílio do debulhador. Fonte: Agência Pará www.agenciapara.com.br/noticia.asp?id_ver=108197

O debulhador (pente) de açaí foi criado pelo agricultor Edilson da Costa com a orientação da equipe da Empresa de Assistência Técnica e Extensão Rural do Pará (Emater). Esta ferramenta é feita em metal inox, morfologicamente similar a um pente, com o objetivo de retirar os frutos das ráquilas sem machucar as mãos, reduzindo o tempo do debulhamento. Este debulhador (pente) não é utilizado no município de Codajás, o debulhamento no estado do amazonas é feito manualmente. 


\section{- Proposta conceitual para o debulhamento}

Nesta pesquisa apresentamos o desenvolvimento de uma proposta conceitual de debulhador fundamentada na tecnologia apropriada. O debulhador compreende um artefato combinado com outros elementos que formam um sistema de debulhamento. $O$ artefato é configurado por dois anéis dentados de diâmetros diferentes unidos por peças cilíndricas que estão soldadas na base dos anéis.

O anel maior possui diâmetro de sessenta centímetros e o menor de quarenta centímetros. O dente maior possui quinze centímetros de comprimento e o menor dez centímetros. O espaçamento entre um anel e o outro corresponde a uma distância de vinte centímetros. Especificações dimensionais adicionais do debulhador encontram-se no apêncie.

O sistema de debulhamento proposto compreende: o aproveitamento de um tonel de óleo diesel de sessenta litros com presilhas soldadas próximas a sua borda, uma saca de nylon de cinquenta quilos, e um sistema de roldana de simples elaboração e de manuseio fixado em um carrinho plataforma encontrado no mercado próprio para o transporte de sacarias. O sistema se configura como um equipamento de operações simples. Inicialmente, um saco de nylon é colocado no interior do tonel e em seguida o cacho de açaí a ser debulhado.

Em seguida os anéis são acoplados à borda do tonel e as presilhas são pressionadas, de modo que a parte superior do cacho fique do lado de fora do último anel, para que possa ser presa por meio da corda e o cacho seja puxado pelo sistema de roldana.

Por fim, será girada a manivela do sistema de roldana para retirar o cacho totalmente debulhado do interior do tonel. Após a realização do debulhamento de vários cachos, o saco de nylon é retirado do tonel e é feito um nó na abertura do saco. Finalizada a operação do debulhamento, as sacas são transportadas por motocicletas ou em transporte de carga para a Cooperativa de Açaí de Codajás.

Esse sistema de debulhamento favorece a saúde do extrativista pois evita calosidades em suas mãos, assim como promove agilidade na tarefa, já que o debulhamento do cacho de açaí é realizado de uma só vez, diferentemente do antigo modo em que uma ráquila é debulhada por vez. 


\section{3 .3}

\section{Proposta para o acondicionamento}

Como já mencionado anteriormente nesta tese, os frutos são acondicionados em cestos, paneiros e rasas feitos com fibras vegetais que proporcionam boa aeração para a conservação dos mesmos, e suportam de $14 \mathrm{~kg}$ a $28 \mathrm{~kg}$ de frutos. Os frutos também podem ser acondicionados em sacos de nylon e caixas de plástico.

Uma dificuldade nesta etapa do processo é transferir os frutos que estão espalhados na lona azul (debulhamento) para as rasas. Nesse sentido, um estudo para o desenvolvimento de um artefato que auxilie nessa transferência dos frutos também merece ser feito. Vale ressaltar, contudo, que ao utilizar o sistema debulhador desenvolvido e proposto no item anterior deste trabalho, no final do processo os frutos debulhados já se encontram em sacas de nylon, que é a maneira de acondicionamento mais empregada no município de Codajás.

\section{3 .4}

\section{Proposta para o transporte}

O transporte dos frutos para os centros de despolpagem ou centros consumidores, como já mencionado, é feito por via fluvial, em embarcações. Primeiramente os frutos são colocados em cestos, paneiros, rasas, caixas de plástico e sacas de fibras sintética que, em seguida, são dispostos nas embarcações. Este transbordo exige um grande esforço físico humano, pois, muitas vezes, o açaizal está localizado em uma área afastada da margem do rio.

Desse modo, o carregamento dos cestos ou sacas de açaí até as embarcações é feito no dorso do agricultor.

Conforme Homma (2006. p. 7), a transferência dos frutos para as rasas compromete a qualidade e o rendimento da polpa. O transbordo do açaí exige uma logística cautelosa em dois aspectos: o tempo empregado nesta atividade e a troca das rasas.

A mudança dos frutos de rasas deve ser evitada, assim como a exposição direta dos frutos ao sol. A logística do carregamento das rasas exige rapidez, e a atividade deve, preferencialmente, ser executada pela manhã. De acordo com Müller e Vasconcelos (2006. p. 4), para obter celeridade no transbordo e minimizar o peso das rasas para o carregador, é indicado o uso de vagonetas 
(Figuras 84 e 85) que se deslocam sobre trilhos, de dentro do açaizal até a margem dos rios.

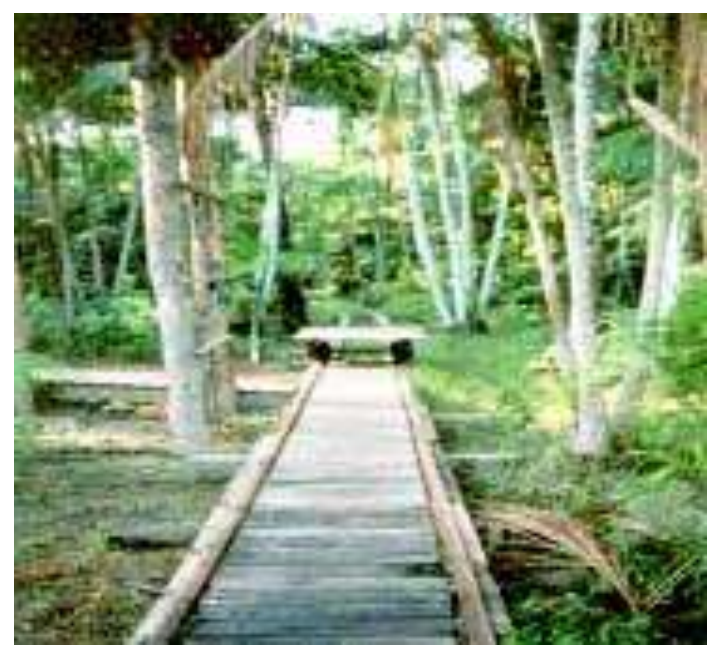

Figura 84 - Vagoneta usada no transporte de frutos de açaizeiro.

Fonte - Antonio Agostinho Müller, Marcus Arthur Marçal de Vasconcelos.

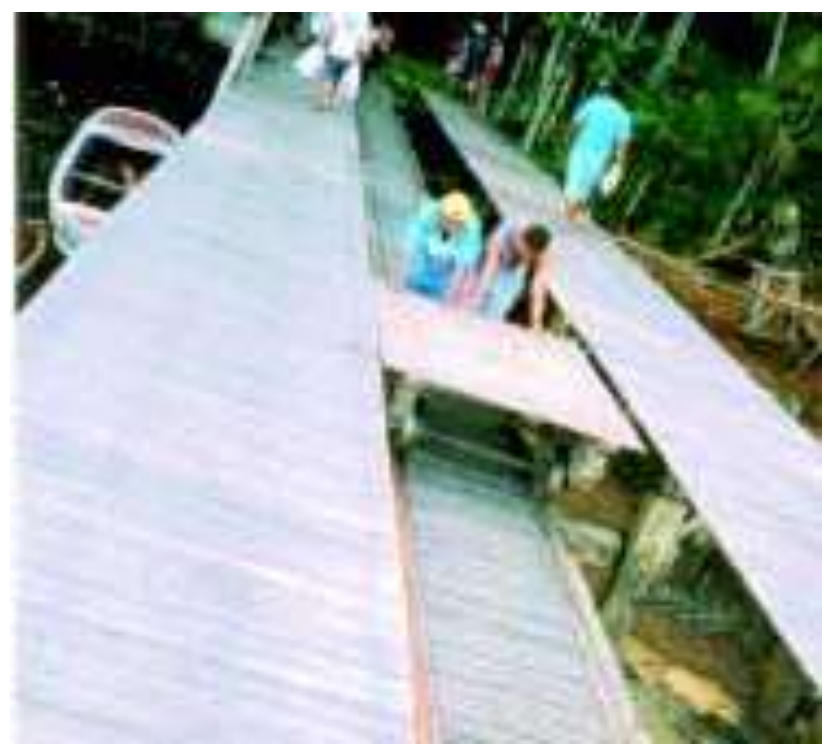

Figura 85 - Vagoneta usada no transporte de frutos de açaizeiro.

Fonte - Antonio Agostinho Müller, Marcus Arthur Marçal de Vasconcelos.

\subsection{5}

\section{Propostas para o aproveitamento de sementes do açaí}

O modelo produtivo do açaí tem como descarte a formação residual das sementes. $O$ descarte acontece no debulhamento. Foi observado que este descarte apresenta dois grupos de sementes, como mostra a Figura 86. Um 
grupo reúne as sementes germinativas empregadas para o plantio, e o outro, as sementes não germinativas, que são estocadas e aproveitadas para diversos fins, como por exemplo para o artesanato, para a geração de energia elétrica, para a pavimentação de calçadas, para a produção de painéis, para a ração animal e como substrato orgânico.

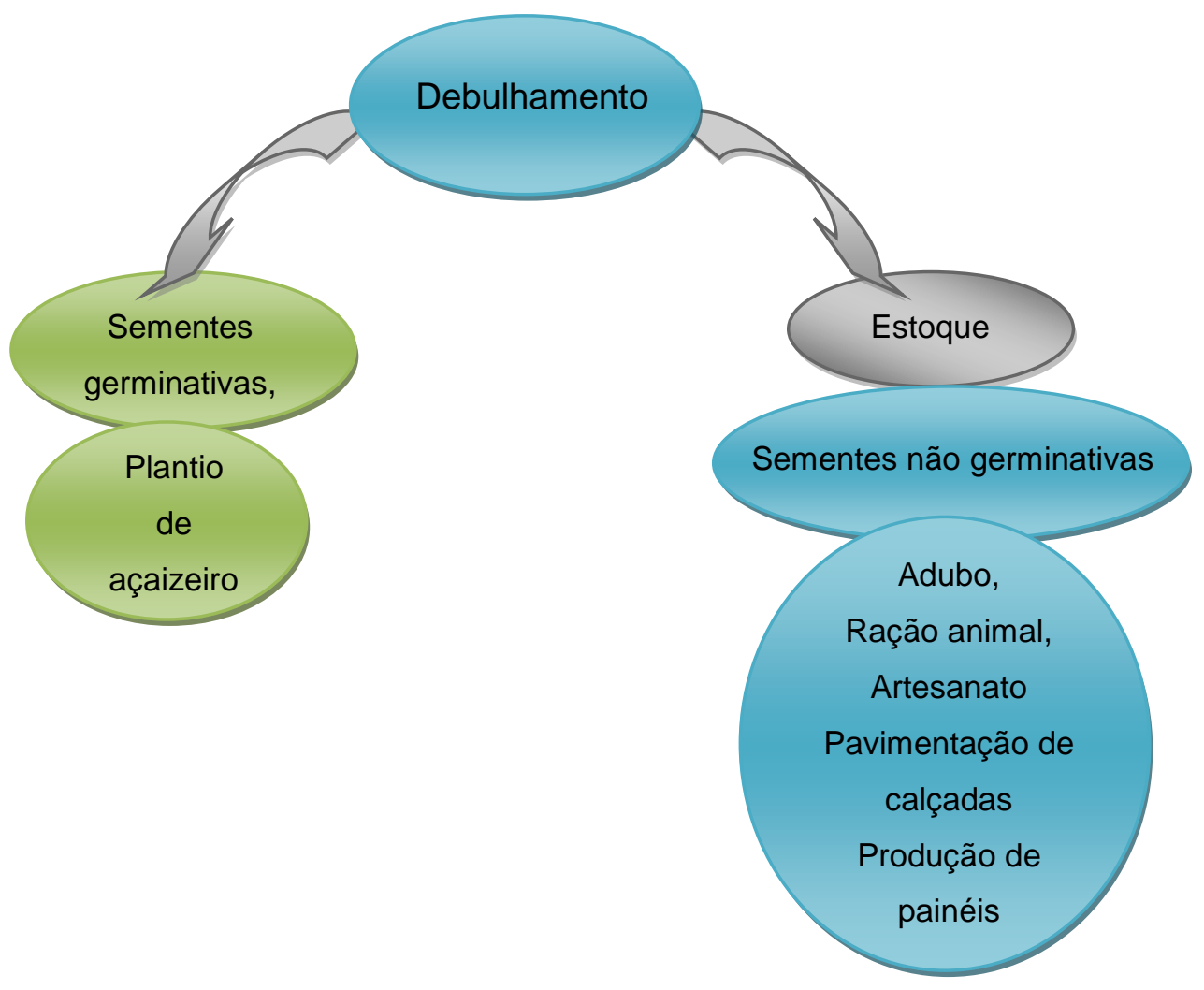

Figura 86 - Descarte da cadeia produtiva e aproveitamento dos resíduos com o aproveitamento das sementes germinativas e não germinativas.

\section{A. Aproveitamento das sementes germinativas}

Vale lembrar que as sementes germinativas são recalcitrantes, ou seja, perdem a capacidade de germinarem. Farias Neto et al. (2006) recomendam que as mesmas sejam plantadas logo após o despolpamento, com o propósito de assegurar a germinação.

O cultivo do açaí só é possível com a germinação de sementes que passaram pelo processo de despolpagem recentemente, sendo necessária apenas uma semente germinativa para o plantio. O restante das sementes pode ser utilizado como substrato para o adubo do plantio do açaizeiro, e, neste caso específico, as sementes podem ser estocadas.

No processo de germinação de sementes o desafio é utilizar as sementes não germinativas para substituir a serragem de madeira, com a finalidade de proporcionar umidade à muda, em proporções iguais ou superiores à produzida 
pela serragem, transformando-as em substrato orgânico para o plantio do açaizeiro.

Farias Neto (2006) orienta que as mudas sejam feitas em camadas estratificadas com serragem de madeira diretamente em sacos de plástico preto, ou em sementeiras (viveiro). A finalidade da serragem é manter a umidade na compostagem.

A proposta de reaproveitamento das sementes é baseada nestas orientações. Farias Neto propõe a utilização de sacos de plástico preto medindo $15 \times 25 \mathrm{~cm}$ para a produção de mudas. Recomenda que se coloque dentro destes sacos três camadas de componentes: a primeira camada de terra preta, em seguida, uma camada de sementes não germinativas e para finalizar, uma outra camada de terra preta (Figura 87).

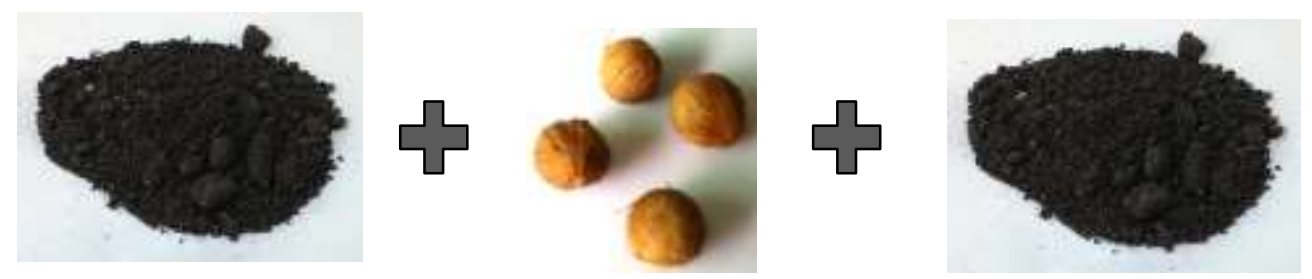

Figura 87 - Aproveitamento das sementes como substrato orgânico: terra preta + sementes do açaí + terra preta.

$\mathrm{Na}$ superfície da muda, é feito um buraco centralizado com $1 \mathrm{~cm}$ de profundidade para a colocação de uma semente germinativa.

O procedimento adotado é análogo ao empregado pela Embrapa Amazônia Oriental, a diferença reside apenas na substituição da serragem de madeira por resíduos do fruto do açaí como substrato.

\section{B. Aproveitamento das sementes não germinativas}

Após o despolpamento, as sementes não germinativas de açaí podem ser estocadas e aproveitadas como material de artesanato, para a geração de energia elétrica, como ração animal e também como substrato orgânico (adubo), como apresentado no processo de aproveitamento das sementes germinativas. Já as fibras das sementes são muitas vezes aproveitadas para a pavimentação de calçadas e para a produção de painéis.

No caso específico de Codajás, a produção de açaí gera o acúmulo de grande número de sementes sem destino manejado e sem aproveitamento. As sementes, descartadas pela despolpadeira, são despejadas na lateral da 
Cooperativa, e desse modo formam um amontoado de sementes, resultante da produtividade ao longo dos seis meses da safra. Uma parte das sementes é vendida para ser utilizada como ração de animais, outra parte, como adubo, mas este procedimento não é suficiente para acabar totalmente com o resíduo que é acumulado durante o semestre.

Neste sentido, propomos duas formas de aproveitamento do resíduo de açaí: uma como elemento constituinte para pavimentação de calçadas e outra como material base para a construção de painéis construtivos.

\section{- Aproveitamento das sementes: pavimentação de calçadas}

$\mathrm{Na}$ primeira forma de aproveitamento, as sementes de açaí não germinativas são utilizadas para a pavimentação de calçadas, pátios e caminhos, ao serem associadas a uma fina camada de argamassa como cobertura. Essa é uma prática construtiva padrão, bastante empregada (Figura 88), na qual os agregados mais utilizados são o seixo e a brita. Os seixos, segundo a NBR $6502^{8}$, são pedregulhos constituídos por minerais ou partículas de rocha, são pedras encontradas no fundo dos rios, transformadas pela ação das marés. A remoção dos seixos compro mete a qualidade dos rios, do mesmo modo, o uso intensivo da brita provoca impactos ambientais. Neste contexto, a substituição do seixo e da brita colabora para minimizar os danos ao meio ambiente.

Este processo de pavimentação, originalmente feito com seixos e brita, nessa proposta utiliza sementes de açaí como substitutivos. As calçadas da cidade de Codajás poderão ser pavimentadas com as sementes, reduzindo a extração de seixos dos rios, o que significa duas ações colaborativas ao meio ambiente: uma é a preservação dos rios, e a outra é proporcionar um destino adequado para o acúmulo das sementes de açaí.

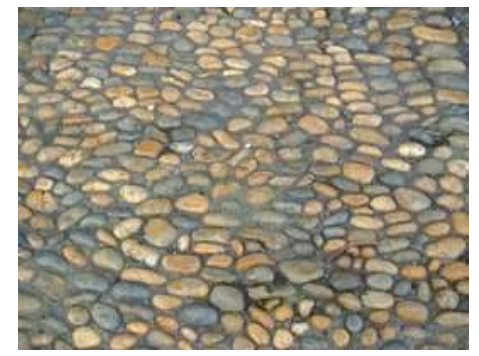

Figura 88 - Foto ilustrativa de calçada feita com seixo e argamassa.

Fonte - http://www.ehow.com.br/pavimentar-usando-pedras-rio-argamassa-como_81555/

\footnotetext{
${ }^{8}$ Normas Brasileiras - NBR 6502: 1995 - ABNT - Associação Brasileira de Normas Técnicas. Esta Norma define os termos relativos aos materiais da crosta terrestre, rochas e solos, para fins de engenharia geotécnica de fundações e obras de terra.
} 


\section{- Aproveitamento das sementes: produção de painéis}

$\mathrm{Na}$ segunda forma de aproveitamento das sementes, propomos sua utilização para a produção de painéis, conforme a metodologia de Quirino (2010. p.78 com algumas adaptações.

Esta produção será realizada no período da entressafra, com o propósito de contornar dois problemas identificados no estudo junto à Cooperativa de Codajás: o acúmulo de sementes e a estagnação das atividades na entressafra, tornando-a um período produtivo e lucrativo para a Cooperativa.

Para a produção dos painéis, será necessário montar uma oficina com bancadas que possibilitem a produção em série.

A produção dos painéis com as sementes de açaí foi adaptada à norma para painéis de madeira aglomerada, a NBR 14810-1, 2 e 3. Esta norma trata dos procedimentos de obtenção, preparação e acondicionamento de corpos-de- prova para ensaios.

A produção dos painéis envolve basicamente três etapas que serão discutidas separadamente: preparo das misturas; prensagens; e estabilização.

Primeira etapa: preparo das misturas.

Esta etapa consiste em homogeneizar gradativamente as sementes com os dois adesivos. Inicialmente, as sementes e a resina são gradativamente homogeneizados manualmente para a retirada de grumos (concentração de adesivo nas sementes) como mostra a Figura 89.

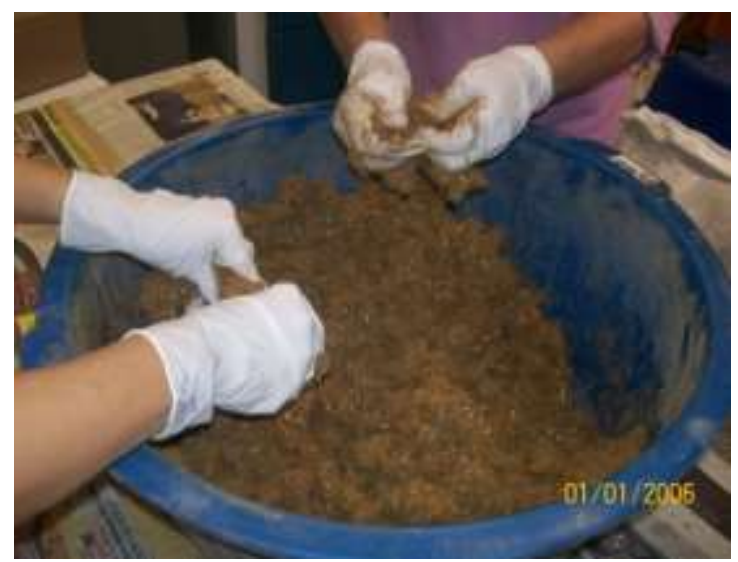

Figura 89 - Homogeneização manual: mistura das sementes do açaí com o adesivo. Fonte - Quirino (2010).

Em seguida, o material é colocado na encoladeira (máquina industrial de homogeneização) por cinco minutos (Figura 100). Após esta etapa, a mistura está pronta para ser pré-prensada. 


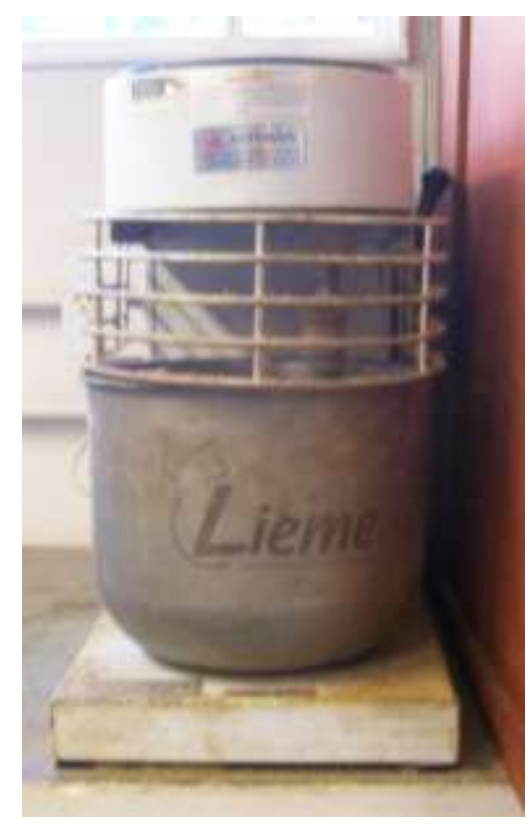

Figura 90 - Homogeneização mecânica (encoladeira): mistura das sementes do açaí com as resinas dentro do recipiente de inox.

Fonte - Quirino (2010. p.80).

\section{Segunda etapa: prensagens}

Esta etapa abrange duas prensagens: a pré-prensagem (prensa mecânica) e a prensagem (prensa hidráulica).

\section{- Pré-prensagem (prensa mecânica)}

Após o material ser totalmente homogeneizado, ele é colocado em um molde feito de madeira, de $40 \times 40 \mathrm{~cm}$ que, por sua vez, encontra-se sobre uma bandeja metálica revestida de material antiaderente. $O$ molde é posicionado numa prensa mecânica, e submetido a uma força de $150 \mathrm{Kg}$ (Figura 101). Nesta etapa, é formada uma placa pré-prensada denominada colchão, pronta para a próxima etapa, a prensagem

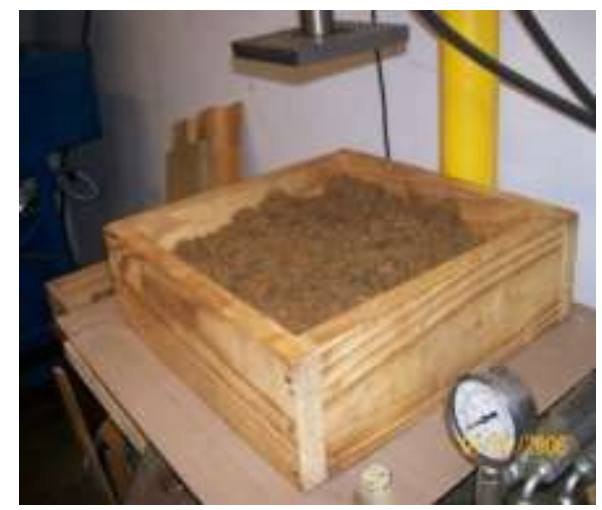

Figura 91 - Pré-prensa (prensa mecânica). Fonte - Quirino (2010). 


\section{- Prensagem (prensa hidráulica)}

Retira-se o molde do colchão, levando-se o colchão na bandeja metálica para ser colocado na prensa hidráulica térmica. O painel preliminar foi submetido a uma pressão durante um período de quinze minutos (Figura 102). Finalizado o processo, o painel segue para a estabilização (cura).
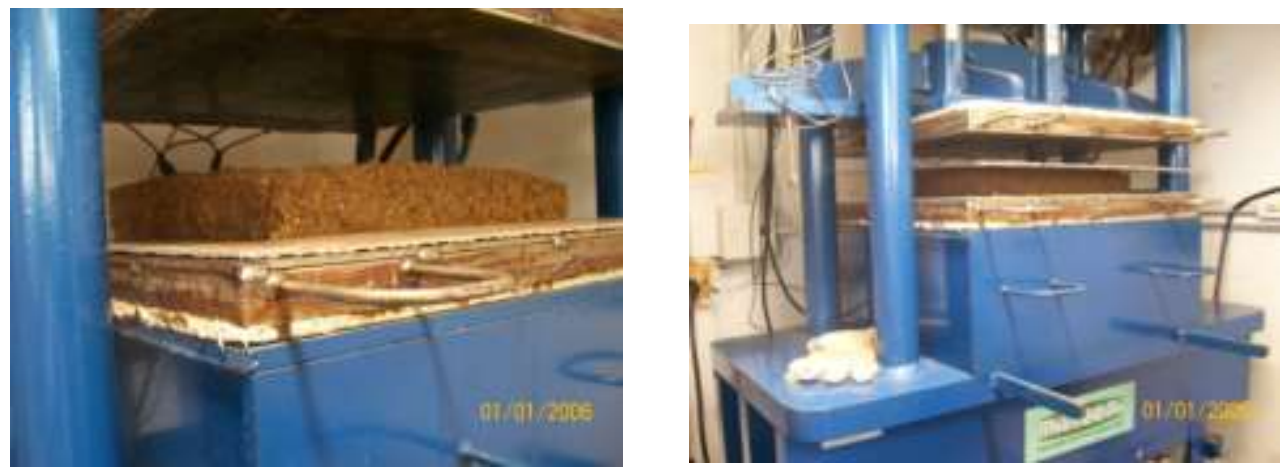

Figura 92a e 92b - (a) Prensa hidráulica da marca Marconi aberta com o colchão e (b) prensa hidráulica descendo a bandeja superior, início da prensagem.

Fonte - Quirino (2010. p.86)

\section{Terceira etapa: Estabilização}

Após quinze minutos de prensagem, o painel está concluído e é colocado em uma bancada para o período de setenta e duas horas de estabilização (Figura 103).
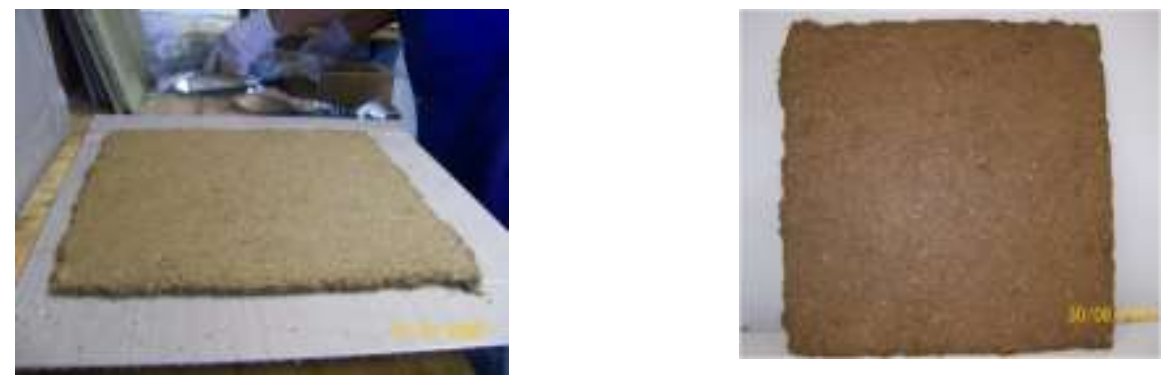

Figura 93a e 93b - (a) Painel finalizado sobre a bandeja metálica e (b) pronto para o período de estabilização (cura).

Fonte - Quirino (2010. p.87)

O leiaute do processo fabril dos painéis compreende a sequência de atividades exercidas em sua maior parte em três bancadas que comportam os materiais e equipamentos. A primeira bancada é destinada à homogeneização. Tal bancada deve permitir a homogeneização manual feita em bacia de plástico e, também, comportar a "encoladeira", máquina industrial que faz a mistura mecanicamente. A segunda bancada é destinada à prensagem, e deve abrigar tanto a prensa mecânica, quanto a prensa hidráulica. Por fim, a terceira bancada, 
destinada à terceira etapa, estabilização, deve ter um suporte onde os painéis são posicionados.

A oficina para o aproveitamento das sementes abrange o processo de produção dos painéis feitos com as sementes do açaí.

Os painéis serão empregados na construção dos elementos que farão parte do complexo turístico rural e cultural, a saber, a escada, as plataformas e as passarelas do arvorismo e as divisórias dos ambientes do espaço cultural.

Por fim, serão reunidas todas as etapas para se formar um modelo conceitual para a produção do açaí do açaí. Este modelo abre espaços para ampliação de soluções inovadoras socialmente, de baixa complexidade fabril e de fácil manejo.

Com base nos critérios norteadores listados no início do capítulo:

- Considerando-se princípios de ecodesign, buscou-se o aproveitamento de todas as sementes. As sementes germinativas foram selecionadas e encaminhadas para o açaizal, e as sementes não germinativas foram aproveitadas para a produção de artesanato, o consumo de ração animal, pavimentação de calçadas e produção de painéis.

- Considerando-se princípios de design social, buscou-se atender ao grupo menos favorecido, de extrativistas ou agricultores familiares, que dispõem de poucos recursos financeiros para manter o modelo produtivo do açaí, como também dispõem de poucas ou nenhuma ferramenta de trabalho.

- Considerando-se princípios de design participativo, o desenvolvimento do modelo conceitual para a produção do açaí buscou a participação dos extrativistas, dos envolvidos na cadeia produtiva do açaí, ou seja, buscouse o estabelecimento de uma colaboração com a comunidade rural.

- Considerando-se os princípios de design para sustentabilidade, buscou-se uma otimização para aumentar a produtividade da cadeia do açaí.

A seguir, apresentamos a proposta de modelo conceitual para a produção do açaí elaborada. O modelo foi definido após o confronto entre as atividades da cadeia produtiva $\mathrm{e}$ as melhorias propostas para $\mathrm{o}$ desenvolvimento da Cooperativa de açaí de Codajás.

Retomamos aqui o organograma das atividades do modelo produtivo do açaí do Amazonas, para transformá-lo na proposta de modelo conceitual para a produção do açaí elaborada a partir do levantamento e análise feitos em campo, da literatura sobre o assunto, de alternativas intermediadas pelo design sustentável, e do aproveitamento de sementes germinativas e não germinativas (Figura 104). 


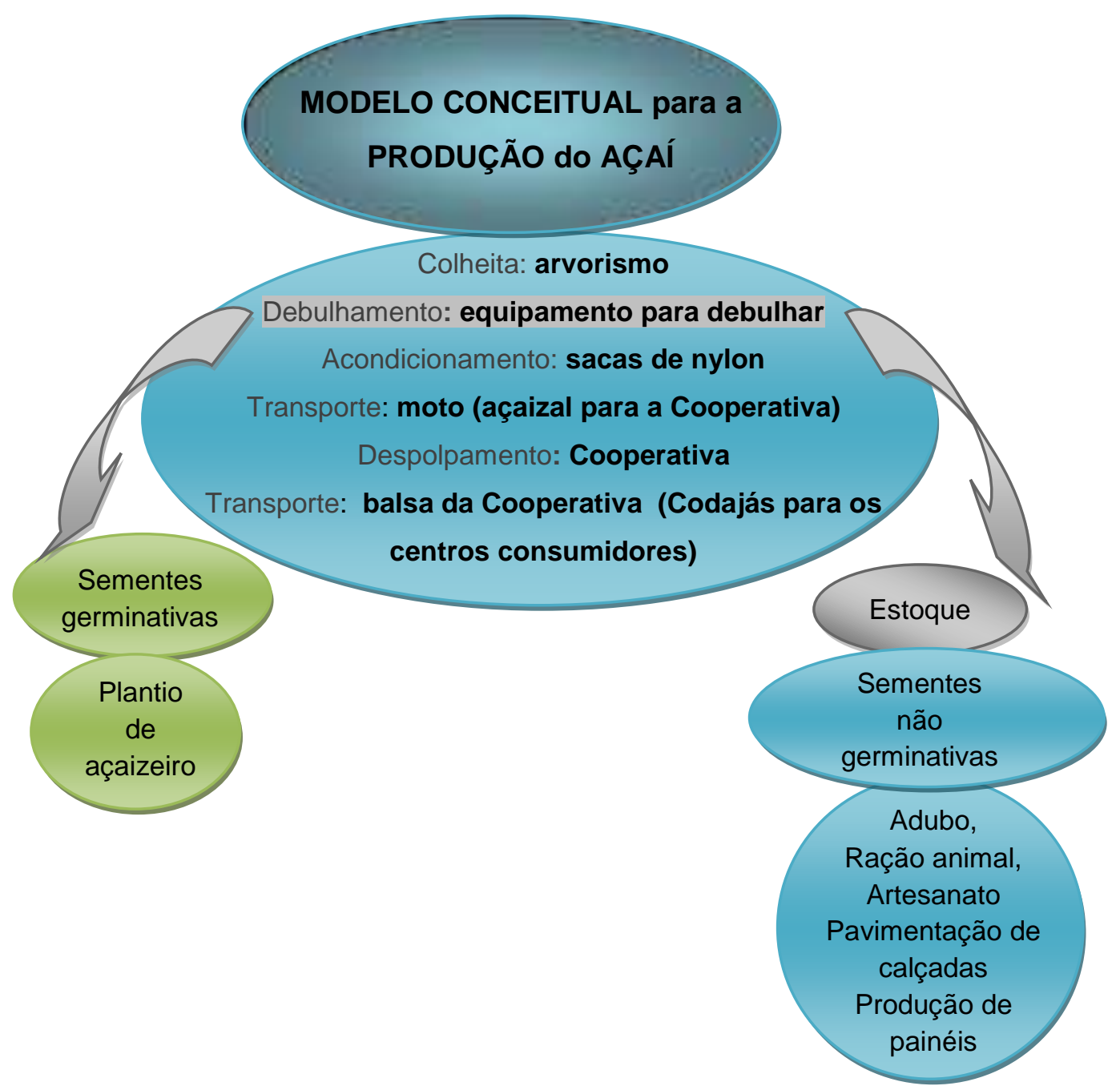

Figura 94 - Organograma do modelo conceitual para a produção do açaí.

Abaixo, apresentamos um organograma contendo propostas para o desenvolvimento da Cooperativa de Açaí de Codajás, com ênfase nas melhorias dos aspectos técnicos (Figura 105). 


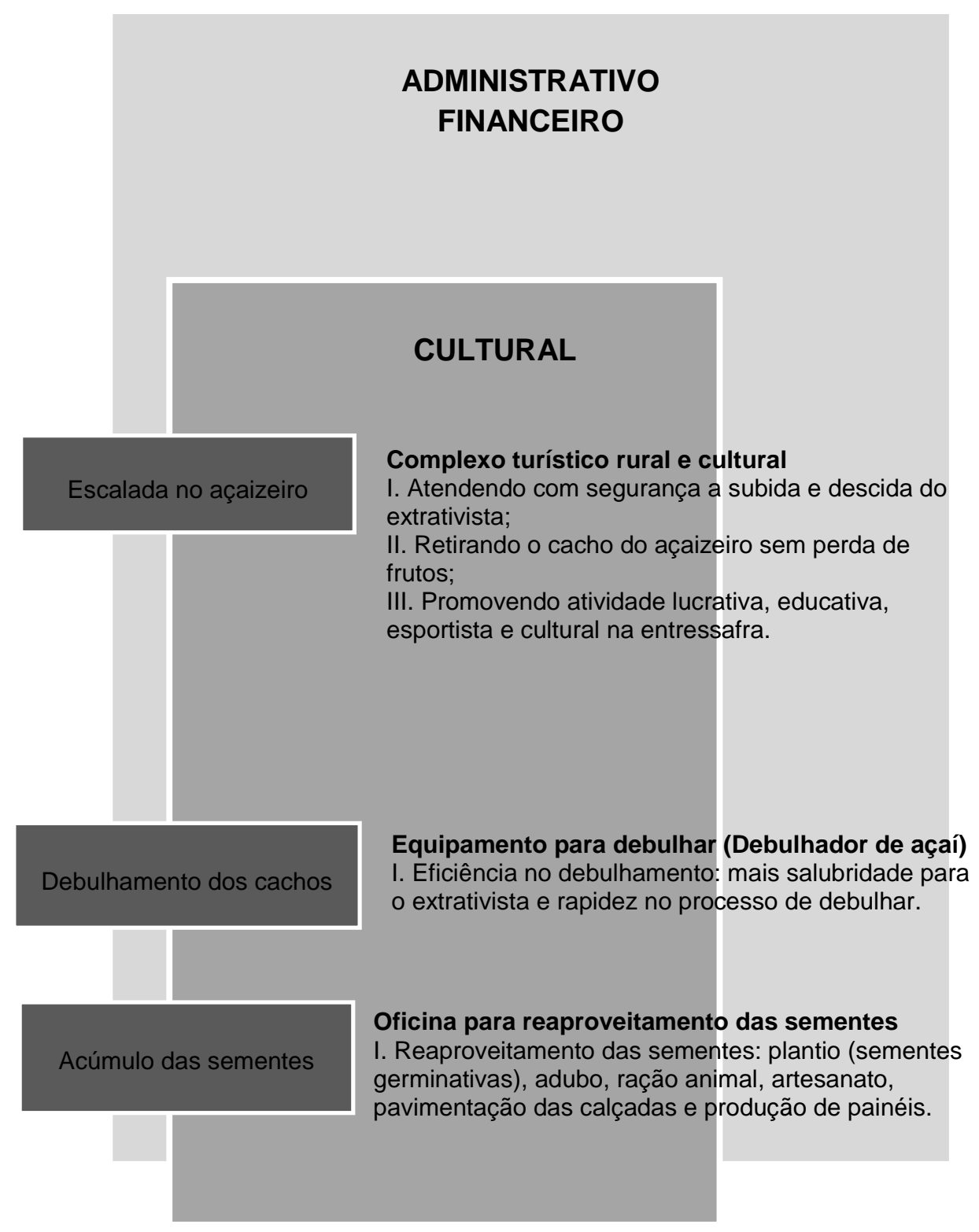

Figura 95 - Organograma das propostas para desenvolvimento da Cooperativa de açaí de Codajás com as melhorias.

O confronto entre o organograma do modelo conceitual para a produção do açaí e o organograma das propostas para o desenvolvimento da Cooperativa resulta em uma intersecção entre as melhorias de aspecto técnico com as melhorias de aspectos administrativo-finaceiro e cultural.

Neste contexto, o desenvolvimento do modelo conceitual para a produção do açaí define as seguintes atividades:

1. Açaizal - Complexo turístico rural e cultural;

2. Colheita do açaí - Arvorismo;

3. Debulhamento - Uso de sistema para debulhar;

4. Aproveitamento de sementes: 


\section{A Sementes germinativas utilizadas no plantio de açaizal;}

4. B Sementes não germinativas empregadas em artesanato, em ração animal, em substrato orgânico, em pavimentação de calçadas e na produção de painéis.

5. Acondicionamento - os frutos permanecem acondicionados em sacos de nylon ou caixas de plástico;

6. Transporte - sacos de nylon ou caixas de plástico serão conduzidos por meio de vagonetas até as margens do rio, e colocados nas embarcações com destino aos centros consumidores;

7. Consumo (maior) é realizado nos grandes centros afastados dos açaizais.

Foi realizado um confronto entre os dois organogramas: o do modelo conceitual para a produção do açaí e o das propostas para o desenvolvimento da Cooperativa. Após este confronto, foi elaborada uma lista de atividades que podem sofrer intervenções, a partir da abordagem do design sustentável, para o desenvolvimento do modelo conceitual para a produção do açaí.

A discussão e justificativas das intervenções propostas tiveram como base os conteúdos tratados nos capítulos 2 e 3.

No Brasil há bastante investimento na realização de grandes festas com visibilidade nacional e internacional, como o carnaval no Rio de Janeiro e as festividades gaúchas no Rio Grande do Sul. No nordeste, por exemplo, as festas juninas valorizam o folclore, a culinária e a cultura regional. Estes grandes eventos, além de proporcionar lazer e cultura, de certo modo promovem desenvolvimento econômico na região. Estes eventos são delineados valorizando-se as peculiaridades de cada região, ou seja, adotando-se uma abordagem endógena como estratégia para o desenvolvimento da região.

Essa abordagem endógena foi comentada no capítulo 2 como um dos pontos favoráveis da tecnologia apropriada. Ela busca encontrar as soluções dos problemas a partir das características locais, como por exemplo, valorizando os seus recursos humanos e materiais. Este procedimento não afasta o emprego de elementos externos, mas evita soluções padronizadas que foram destinadas para uma outra realidade e são forçosamente impostas como modelos. O propósito da abordagem endógena é valorizar internamente o potencial da comunidade e avaliar as suas fragilidades para buscar alternativas que possam fortalecer e consolidar seus aspectos sociais, culturais e políticos, e em virtude deste feito esta comunidade consiga projeção econômica e visibilidade externa. Como nos exemplos de eventos citados acima.

Tais eventos estão sendo mencionados como exemplos de casos bem sucedidos, que estimam o desenvolvimento endógeno e podem ser reaplicados 
em outras regiões. Mas, na própria região do Amazonas temos eventos que podem ser trazidos como referência, como é o caso do Festival Folclórico de Parintins ou Festa do Boi, como também é conhecida, que é uma das maiores festas populares do Brasil e ocorre em Junho na ilha Tupinambarana - Parintins . Tal festa trata de uma disputa entre os bois Garantido (representado pela cor vermelha) e Caprichoso (representado pela cor azul), e o evento também tem uma versão que se realiza em Manaus.

O Festival Folclórico de Parintins surgiu no ano de 1965, e desde então vem realizando grandes eventos, sendo um dos maiores vetores de divulgação da cultural local. A partir desta referência, em 1987 o município de Codajás criou seu próprio evento, a Festa Cultural do Açaí.

Os exemplos de sucesso de festas brasileiras e a existência de um evento cultural consolidado em Codajás, que valoriza a atividade produtiva local do açaí, nos fazem considerar pertinente e adequada a proposta de intensificação do turismo rural e cultural na região, com ênfase no arvorismo e em ambientes construídos adaptados para eventos culturais.

Vale ainda retomarmos questões geopolíticas da Amazônia, que foram abordadas no capítulo 3, que nos ajudam a fundamentar as intervenções do design sustentável propostas para o desenvolvimento do modelo conceitual para a produção do açaí. Isso porque a configuração urbana atual em vários municípios do Amazonas, como no município de Codajás, foi influenciada pelas variáveis do "fenômeno urbano"

É pertinente fazer uma analogia entre as variáveis do "fenômeno urbano" e suas implicações que comprometem o desenvolvimento econômico, cultural, social e político de Codajás. Após a entrevista com a presidente da Cooperativa, a senhora Franciani, foi possível constatar que a continuidade dos problemas da Cooperativa está em parte relacionada ao comportamento indígena que se mantém desde a formação urbanística do estado. A conduta indiferente que os cooperativados mantém perante as atividades produtivas do açaí, como já comentado anteriormente, pode ser comparada à formação das alianças entre os índios e os portugueses que renderam construções de vilas, porém não foi determinante para a formação urbana. (MACHADO,1999. p. 2)

Os índios possuem costumes e dinâmica de trabalho diferentes das dos portugueses. Estes fatos contribuíram para frustrar a expectativa dos portugueses com relação aos índios. O comportamento dos índios é resumido, na visão dos portugueses, como indiferença indígena, ou melhor, como o índio sendo um povo preguiçoso. Entretanto, a questão é que o índio só trabalha quando motivado 
conforme seus valores e seus costumes. Valores e costumes que são desrespeitados, e por este motivo, a civilização indígena acaba sendo mal interpretada.

O fato é que esse comportamento apático dos índios vem sendo reproduzido por gerações e influencia o desempenho do povo ribeirinho, que por sua vez se reflete na conduta dos cooperativados. Os cooperativados, na maioria jovens, mostram-se indiferentes e desinteressados pela atividade produtiva da Cooperativa, apesar dela ser uma atividade lucrativa, segundo a senhora Franciani.

Para amenizar esta indiferença dos cooperativados jovens é necessário compreender seu universo e encontrar motivações para atrair estes jovens. Os jovens são arrebatados pelos esportes e pelas artes, por suas características desafiadoras e liberdade de criação. E devemos pensar tanto no esporte como na arte como fortes aliados estratégicos para aproximar os jovens das atividades produtivas da Cooperativa.

Portanto, é fundamental pensar em intervenções do design sustentável para o desenvolvimento do modelo conceitual para a produção do açaí, considerando as questões ambientais, sociais e culturais envolvidas neste cenário revelado pela Cooperativa de Açaí de Codajás. É necessário encontrar alternativas que favoreçam o envolvimento dos cooperativados; que dinamizem as atividades na entressafra; que busquem melhorias nas condições e segurança de trabalho e por fim, que evitem o desperdício de matéria-prima.

A seguir, apresentamos o modelo produtivo do açaí vigente com a finalidade de entendermos visualmente as etapas do processo (Figura 106). 


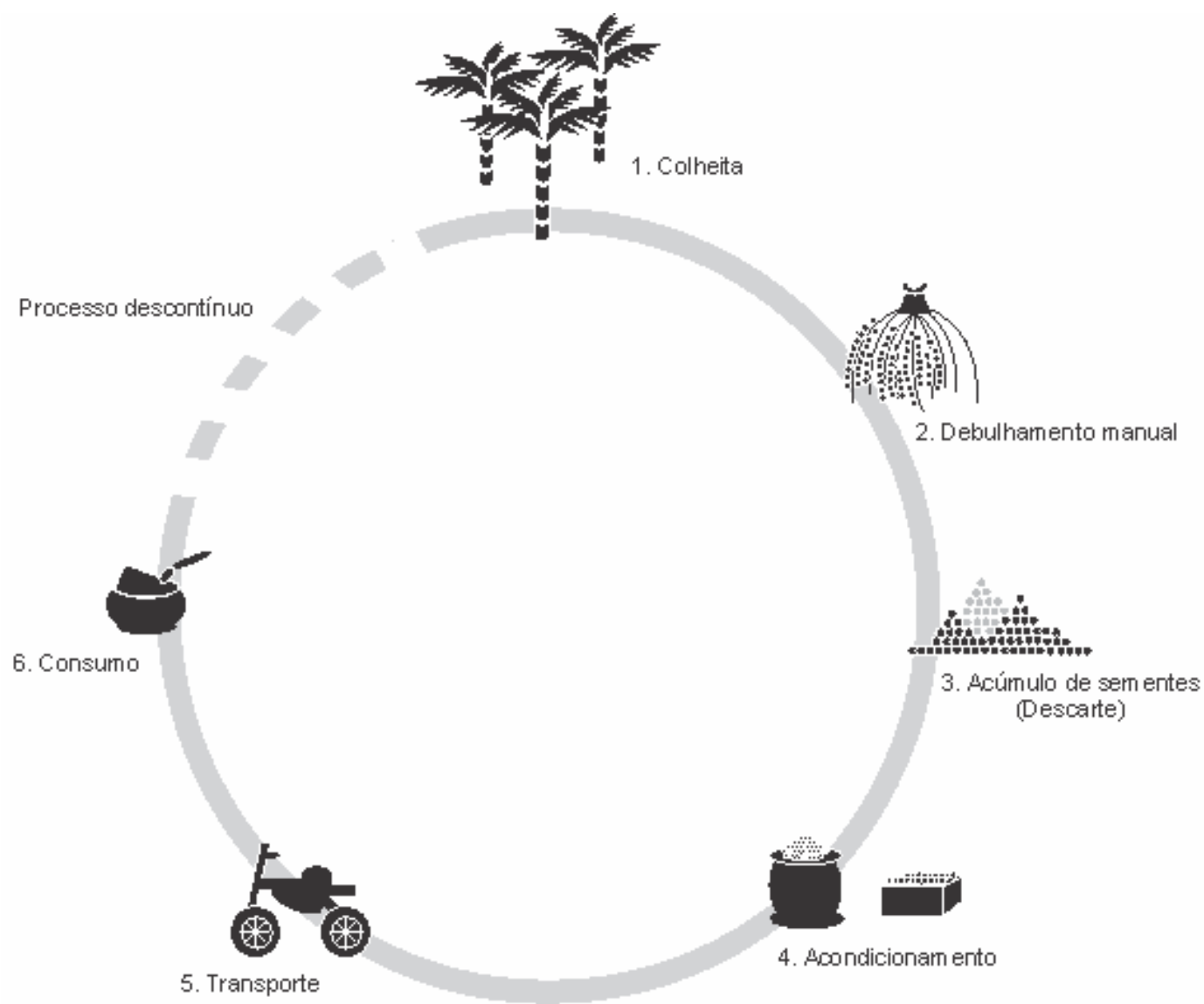

Figura 96 - Desenho ilustrativo do modelo de açaí vigente.

O modelo produtivo do açaí vigente é um processo descontínuo que não atende a segurança do agricultor na colheita; não viabiliza a retirada dos frutos, de modo ágil; e não busca alternativas para o aproveitamento total das sementes; enfim, não vislumbra melhorias sociais e ambientais para os envolvidos no processo. A falta de segurança e a insalubridade para o agricultor podem provocar acidentes e interromper as atividades. Uma averiguação ergonômica pode minimizar estas questões. Do mesmo modo, o não aproveitamento das sementes representa um acúmulo de resíduos sem manejo adequado que provoca um problema ambiental necessitando de uma minuciosa avaliação. Nestes moldes, uma avaliação ambiental colabora para a elaboração de um processo produtivo contínuo.

O atual modelo produtivo do açaí abrange procedimentos descaracterizados da averiguação ergonômica e da avaliação ambiental. Estas avaliações evitam os transtornos e as interrupções das atividades favorecendo a continuidade do processo produtivo. 
Neste sentido, como já foi citado anteriormente, apresentamos uma proposta de modelo conceitual para a produção do açaí no Estado do Amazonas que inclui a implementação do arvorismo e de um espaço cultural, em paralelo, com o desenvolvimento do debulhador de açaí e uma oficina para o aproveitamento de sementes (Figura 107). Em seguida, apresentamos a Tabela 3 com as respectivas melhorias técnicas, ambientais, sociais e culturais propostas no modelo conceitual. 


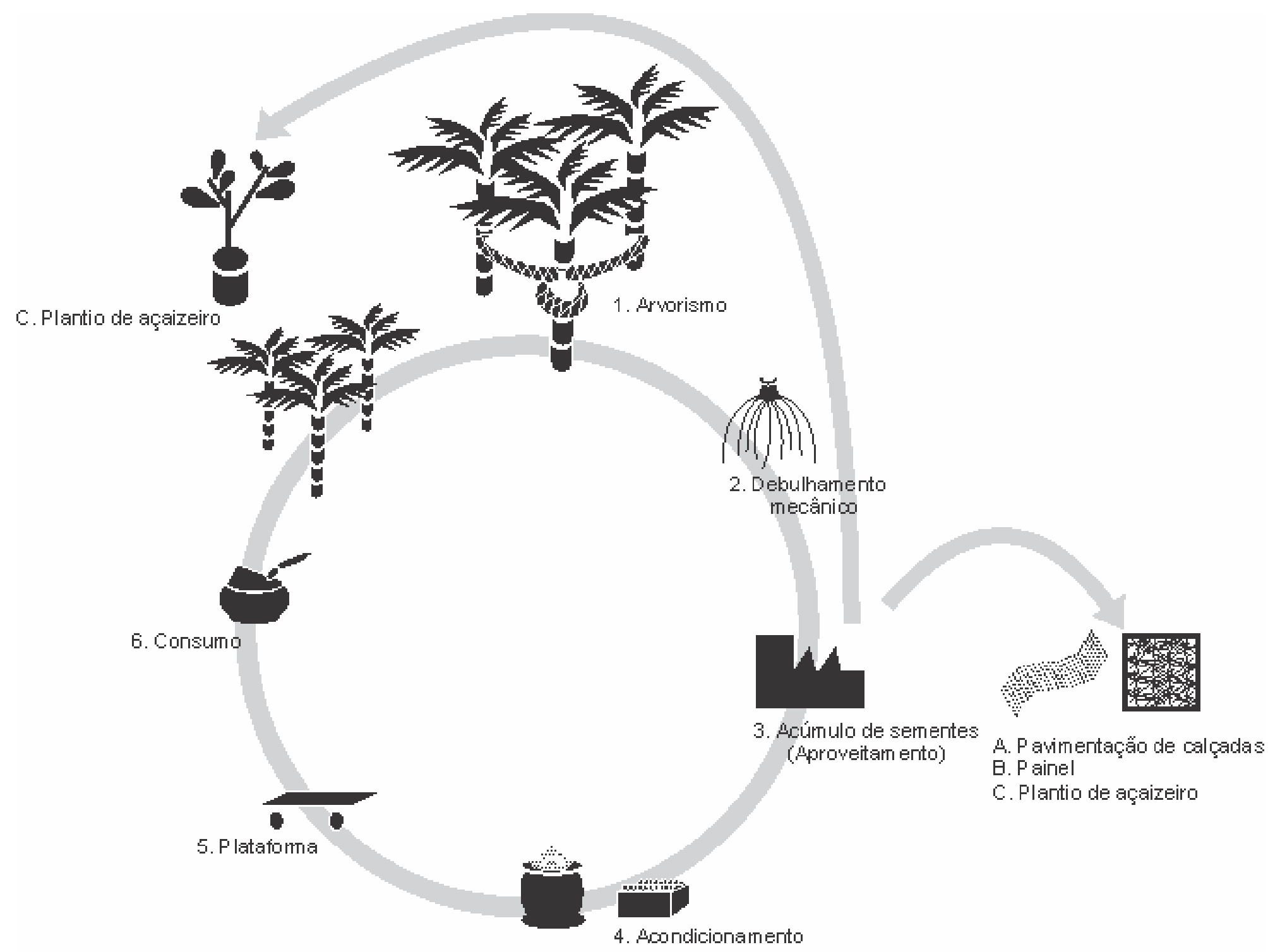

Figura 97 - Proposta de um modelo conceitual para a produção do açaí no Estado do Amazonas. 


\begin{tabular}{|c|c|c|c|}
\hline & $\begin{array}{l}\text { MELHORIA } \\
\text { TÉCNICA }\end{array}$ & $\begin{array}{l}\text { MELHORIA } \\
\text { AMBIENTAL }\end{array}$ & $\begin{array}{l}\text { MELHORIA SOCIAL } \\
\text { e CULTURAL }\end{array}$ \\
\hline \multirow[t]{2}{*}{ 1. Açaizal } & Plantio do açaizal & $\begin{array}{l}\text { Conservação do } \\
\text { ambiente }\end{array}$ & $\begin{array}{l}\text { Valorização das } \\
\text { atividades do açaí }\end{array}$ \\
\hline & $\begin{array}{l}\text { Complexo turístico } \\
\text { rural e cultural }\end{array}$ & $\begin{array}{l}\text { Conservação do } \\
\text { ambiente }\end{array}$ & $\begin{array}{l}\text { Envolver os jovens; } \\
\text { Otimizar a Festa } \\
\text { Cultural do Açaí; } \\
\text { Promover cursos } \\
\text { técnicos e } \\
\text { educacionais; } \\
\text { Dinamizar entressafra }\end{array}$ \\
\hline 2. Colheita & Arvorismo & $\begin{array}{l}\text { Conservação do } \\
\text { ambiente }\end{array}$ & $\begin{array}{l}\text { Segurança para o } \\
\text { escalador; } \\
\text { Aumento da } \\
\text { produtividade; } \\
\text { Envolvimento dos } \\
\text { jovens. }\end{array}$ \\
\hline $\begin{array}{l}\text { 3. Debulhamento } \\
\text { dos cachos }\end{array}$ & $\begin{array}{l}\text { Debulhador dos } \\
\text { cachos }\end{array}$ & $\begin{array}{l}\text { Proteção para o } \\
\text { coletor }\end{array}$ & $\begin{array}{l}\text { Aumento da } \\
\text { produtividade; } \\
\text { Valorização das } \\
\text { atividades do açaí }\end{array}$ \\
\hline $\begin{array}{l}\text { 4. Aproveitamento } \\
\text { das sementes }\end{array}$ & $\begin{array}{l}\text { Oficina de } \\
\text { aproveitamento } \\
\text { das sementes }\end{array}$ & $\begin{array}{l}\text { Manejo de } \\
\text { resíduo }\end{array}$ & $\begin{array}{l}\text { Valorização das } \\
\text { atividades do açaí }\end{array}$ \\
\hline $\begin{array}{l}5 . \\
\text { Acondicionamento }\end{array}$ & Sacos de nylon & $\begin{array}{l}\text { Conservação do } \\
\text { ambiente }\end{array}$ & $\begin{array}{l}\text { Valorização das } \\
\text { atividades do açaí }\end{array}$ \\
\hline 6. Transporte & Vagonetas & $\begin{array}{l}\text { Conservação do } \\
\text { ambiente }\end{array}$ & $\begin{array}{l}\text { Valorização das } \\
\text { atividades do açaí }\end{array}$ \\
\hline 7. Consumo & Centros urbanos & $\begin{array}{l}\text { Conservação do } \\
\text { ambiente }\end{array}$ & $\begin{array}{l}\text { Valorização das } \\
\text { atividades do açaí }\end{array}$ \\
\hline
\end{tabular}

Tabela 3 - Melhorias: técnicas, ambientais, sociais e culturais do modelo conceitual para a produção do açaí. 


\title{
5.4 \\ Considerações sobre o Modelo Conceitual para a Produção do Açaí no Estado do Amazonas
}

\begin{abstract}
Esta proposta de modelo conceitual para a produção do açaí é resultante do desenvolvimento de processos e de produtos. $O$ desenvolvimento compreendeu a proposta de exploração e instalação do arvorismo na região; a adaptação de ambiente construído para abrigar um espaço cultural; a criação da oficina e capacitação de pessoal para o aproveitamento de sementes; a criação e desenvolvimento de debulhador de açaí. Estes processos e produtos foram fundamentados em metodologias emergentes de design, como ecodesign, design social, design participativo, design sustentável e tecnologia apropriada. Todas comentadas no capítulo 2.
\end{abstract}

O design social, o design participativo e o design sustentável influenciaram diretamente o desenvolvimento de processos e produtos, e os princípios de tecnologia apropriada foram essenciais nos aspectos técnicos do projeto do debulhador de açaí.

O arvorismo, o espaço cultural e a oficina para o aproveitamento de sementes do açaí colaboram para o aprimoramento da cultura do açaí, ressaltando as questões de sustentabilidade para os cooperativados.

$\mathrm{Na}$ banca de defesa desta tese recebemos preciosas contribuições e sugestões a respeito das melhorias para o processo produtivo do açaí que mereceram incorporação no texto e uma reflexão, que se segue.

Uma sugestão dizia respeito ao desenvolvimento de um sistema de compostagem dos resíduos, cujos equipamentos pudessem ser desmontáveis em caso de necessidade de transporte para outro local. Já havíamos proposto um processo semelhante à compostagem nas páginas 156 e 157, tratando do reaproveitamento das sementes germinativas e não germinativas como substrato orgânico (adubo). Sem dúvida a compostagem não apenas como parte de um processo interno, mas também como um negócio para a Cooperativa de Codajás poderia ser pensada, ampliando a visão de reaproveitamento dos resíduos.

Uma outra sugestão apontada referia-se ao uso de tecnologia local disponível e sucatas de bicicleta e motos, entre outros, para a construção e manutenção de equipamentos a serem utilizados nos processos de colheita, debulhamento e transporte do açaí . Desta forma, se dependeria minimamente de peças e materiais vindos de fora, uma vez que sempre haverá na região técnicos 
e oficinas com equipamentos de solda, corte, viradeiras para metal, entre outros. A autonomia na fabricação local e manutenção dos produtos propostos se apresenta como uma necessidade. Esta sugestão já havia sido contemplada, de certa forma, na Tecnologia Apropriada que foi empregada para o desenvolvimento da proposta do debulhador (página 152).

Em relação a caminhos e trilhas para facilitar o transporte das sacas entre os locais de colheita, de debulhamento e de distribuição para os centros de consumo, foram sugeridos estrados suspensos do solo, modulados e encaixáveis entre si. Estes estrados seriam suspensos sobre estacas para não prejudicarem a conectividade biológica dos locais onde fossem instalados. Na página 154, de acordo com Müller e Vasconcelos (2006. p. 4), descrevemos o uso de vagonetas (Figuras 84 e 85) que se deslocam sobre trilhos, de dentro do açaizal até a margem dos rios, com o objetivo de obter celeridade no transbordo e de minimizar o peso das rasas para o carregador. Trabalharmos com a ideia de trilhos suspensos certamente enriquece nossa proposta

Um outro ponto levantado foi a promoção de festivais para dinamizar a região. Como abordado na página 147, uma das propostas pensadas para a programação do espaço cultural foi de exploração da Festa Cultural do Açaí em seus aspectos de valorização da cultura local, fazendo com que mais pessoas conheçam e se envolvam na produção do açaí.

Em relação ao turismo cultural e rural, comentou-se ser ele uma fonte inesgotável de ideias para "o bom design", adaptado aos recursos, tecnologias e saberes locais. O turismo cultural e rural como conceito aplicado a uma proposta de modelo conceitual para a produção do açaí, aproximando a economia e o meio-ambiente, se mostrou bastante pertinente e adequado.

Outras sugestões como por exemplo a fabricação de papel a partir dos resíduos do açaí; projetos de rasas e ou caixas modulares dobráveis, para serem estocadas, e tecidas com as técnicas dos cestos do Mercado Ver o Peso de Belém, onde a grande tônica é permitir rigidez e a melhor aeração possível do fruto; a fabricação de bebidas de açaí (vinhos e cervejas); a construção de pousadas na beira do rio para receber visitantes; e a criação de um clube atlético social com time de futebol oficial, e estímulo à prática da canoagem, vela e esportes aquáticos em geral também foram levantadas, mas fugiam um pouco do foco da pesquisa, direcionado às possibilidades de atuação do design na colheita, no debulhamento e no aproveitamento das sementes. Algumas, contudo, poderão ser incorporadas na programação do centro cultural. 
Três sugestões, entretanto, se mostraram muito pertinentes e gostaríamos de comentá-las: o desenho de uma nova peconha; um sistema de cabos e roldanas para transportar os frutos; e uma armação desmontável para a coleta dos frutos.

O desenho de uma nova peconha, talvez usando percintas de nylon. poderia conciliar peconhas para os braços e as pernas. Para o seu desenvolvimento, sugeriu-se a realização de um levantamento detalhado junto ao Corpo de Bombeiros, a verificação da logística de aeroportos, Para-sar, Batalhão da Selva e outros com a finalidade de se estudar detalhes de equipamentos, principalmente para escaladas e transporte.

O desenho de uma nova peconha em princípio se mostra semelhante ao desenho de equipamentos de alpinismo industrial. $O$ alpinismo compreende uma técnica para escalar locais de difícil acesso, utilizando cordas e equipamentos específicos de descida e subida, em atividades que envolvem risco de queda e dificuldades de acessibilidade. O equipamento de alpinismo industrial é utilizado conforme a Norma Regulamentadora - 18 (Condições e Meio Ambiente de Trabalho na Indústria da Construção).

Aprofundando um pouco mais o estudo, verificamos que um equipamento similar ao do alpinismo se apresenta como uma alternativa interessante no que tange aos quesitos de segurança. Entretanto, quanto à praticidade do equipamento, surgem algumas questões que merecem ser colocadas em pauta.

O equipamento dispõe de várias peças em metal resultando em um sobrepeso e requerendo um vestuário específico produzido com material resistente e encorpado, o que pode restringir a mobilidade corporal. Além disso, em geral este tipo de equipamento é favorável em atividades que são executadas por uma equipe de trabalhadores que são remanejados ou substituídos em intervalos de horas trabalhadas. Desse modo, o sobrepeso e a restrita mobilidade proporcionada pelo equipamento são compartilhados entre os trabalhadores e os esforços físicos são amenizados.

A escalada no açaizeiro compreende um trabalho individual, praticamente isolado, sem substituição de trabalhador e requer uma agilidade corporal. Além de ser necessário um esforço físico para subir no açaizeiro, o escalador precisa desprender energia para realizar um longo trajeto até o açaizal, transportando as sacas de açaí e suportando o calor e a umidade da floresta, o que representa mais um incomodo proporcionado pelo vestuário. Portanto, o escalador está habituado a levar consigo para o interior do açaizal apenas uma faca e um saco 
de nylon vazio, considerando que o seu retorno estará condicionado ao carregamento das sacas cheias de açaí.

Um sistema de cabos e roldanas, penduradas em árvores ou mesmo no equipamento de arvorismo, para transportar os fardos de frutas diretamente da floresta para as embarcações esperando nas margens, foi uma outra sugestão inovadora, que tornaria o processo mais rápido e menos cansativo para o agricultor. Este sistema propõe uma infraestrutura simples e de baixo custo, admitindo as árvores como elementos estruturais de fixação para os cabos e as roldanas. No entanto, devemos ressaltar que esta sugestão seria implementada em um ambiente de floresta. Um ambiente que não é padronizado, apresentando ora áreas densas e ora vazios de vegetação.

Uma floresta compreende em geral árvores de vários tamanhos. Especificamente nesta região, o esboço geográfico da floresta é diversificado e imprevisível. Algumas árvores poderão ser aproveitadas como elementos estruturais para a fixação dos cabos e roldanas, outras árvores serão inviáveis como elementos estruturais. Ressaltamos, também, a questão das variáveis climáticas (sol forte e chuva intensa) que colocam em cheque a eficácia e a vida útil dos equipamentos instalados na floresta. Neste sentido, devem ser considerados a formação vegetativa e as condições climáticas da floresta como variáveis para o desenvolvimento do sistema de transporte de frutos. Além das variáveis mencionadas, deve-se projetar um plano de monitoramento para o trajeto entre o açaizal e as margens do rio onde se encontram as embarcações, uma vez que ele é um trajeto longo e repleto de incidentes.

Apesar dessa proposta de sistema de transporte de frutos empregar uma infraestrutura simples e de baixo custo, o desenvolvimento do sistema, sua execução e operação não são tão simples como parece, pois requerem um estudo minucioso e cauteloso em razão das adversidades da floresta.

Temos uma percepção romântica de que a floresta é um ambiente acolhedor, no entanto, ela se revela inóspita e de difícil monitoramento de todas as suas ações.

Acreditamos que esse sistema de transporte de frutos seja mais adequado em um ambiente fabril, um local onde seja possível se prever os incidentes e monitorar a trajetória. O ambiente fabril, contudo, é antagônico ao ambiente da floresta, existindo pouca ou nenhuma semelhança entre eles. Entretanto, entendemos ser possível a implementação de um sistema apesar do confronto de situações. 
Por fim, gostaríamos de comentar a proposta de uma armação desmontável, composta de lona coletora e estacas desmontáveis para suportar essa lona coletora de frutos na debulha. As estacas, no caso, servem para manter a lona longe do chão e da possível contaminação com o solo. O conjunto todo poderá ser desmontado, enrolado e colocado num suporte provido de alças para ser levado no ombro.

A armação desmontável para a debulha é viável e factível, se configurando como um método simples, inovador e confortável para os agricultores. Além destas vantagens, a armação valoriza a conectividade biológica, um conceito que possui estreita relação com a sustentabilidade.

A conectividade biológica se caracteriza pela livre circulação de espécies diferentes entre os diversos habitats, sem interrupções e sem causar danos para os envolvidos. Esta circulação busca vários recursos que facilitam o fluxo, como por exemplo, corredores, pontes, trilhas suspensas do solo, entre outros. A conectividade biológica é um procedimento também adotado pelo ser humano.

Essa última alternativa é similar à sugestão do sistema de transporte de frutos. Propõe-se projetar e detalhar veículos movidos por força humana, especializados para o transporte de fardos (vide Papanek). O mesmo se aplica a projetos de tirolesas e cestos utilizados no sistema de cabos suspensos para transporte da carga desde a origem até a fábrica ou o transporte.

Neste sentido, as sugestões mencionadas são interessantes para esta pesquisa, podendo com alguns ajustes e adaptações ser aplicadas à realidade de Codajás. 


\section{Considerações finais}

A pesquisa tratou de um tema ainda pouco explorado na literatura, no que tange ao desenvolvimento de um modelo conceitual para a produção do açaí no Estado do Amazonas, diferentemente da literatura e pesquisa encontradas, referente ao valor nutricional da polpa do açaí, que favorece a economia regional e estabiliza o consumo do fruto nos mercados nacional e internacional. A pesquisa aqui desenvolvida é, portanto, pontual, e busca indicar melhorias nas diversas etapas do modelo conceitual para a produção do açaí, em diferentes atividades, com vistas a um modelo sustentável.

Para a realização deste modelo conceitual para a produção do açaí, foi feito um levantamento teórico a respeito do design e sua interface com a sustentabilidade. Como pano de fundo para esta discussão, foram estudados o Design Orientado ao Meio Ambiente (DfE - Design for Environment), a Análise do Ciclo de vida do Produto - ACV (Life-Cycle Assessment - LCA), conceitos de ecodesign, design social, design participativo, design sustentável e, por fim, a tecnologia apropriada.

Em seguida, uma visão da geopolítica do Amazonas foi trazida, para que a complexidade dos parâmetros de desenvolvimento da região fossem conhecidos e, desse modo, fosse possível o entendimento de um modelo conceitual para a produção do açaí e suas implicações ambientais, políticas, sociais e econômicas. Apesar da complexidade geopolítica do Amazonas, a ocorrência de iniciativas sustentáveis tem sido relatada com bons resultados, levando-nos a crer que é possível e desejável a implementação de projetos sustentáveis na região. Nesta pesquisa, foram comentados dois exemplos como referência de modelos sustentáveis em cenários complexos. Estes modelos estão sendo implementados no interior do estado do Amazonas, coordenados pela Fundação Amazonas Sustentável - FAS, e pela Zona Franca de Manaus - ZFM.

Na sequência, foi realizada uma pesquisa de campo em duas localidades: em um açaizal nas proximidades do município de Iranduba; e no município de Codajás, na Cooperativa de Açaí. A partir desses levantamentos de campo foi definida a Cooperativa de Açaí de Codajás como objeto de estudo para o desenvolvimento de um modelo conceitual para a produção do açaí.

A Cooperativa de Açaí de Codajás, nesta pesquisa, foi colocada como o cerne do modelo conceitual para a produção do açaí no estado do Amazonas. Foi 
feito um levantamento dos seus problemas e apontadas soluções inspiradas em um design sustentável que, por sua vez, cumpre um papel estrategista para o desenvolvimento econômico da região.

A comprovação da hipótese foi se revelando na medida em que foram sendo aprofundados os problemas e soluções para a Cooperativa de Açaí de Codajás. O trabalho de avaliação dos problemas e suas conexões nos âmbitos administrativo-financeiro; social e cultural; e técnico foi fundamental para a proposição de soluções adequadas à realidade da Cooperativa de Açaí de Codajás.

Ao longo da pesquisa, foram apresentados e estudados dois documentos marcantes para a área do Design: Desenvolvimento pelo design e Diretrizes Básicas para Políticas de Design Industrial em Países em Desenvolvimento, ambos elaborados pelo Conselho Internacional das Sociedades do Desenho Industrial (ICSID) e pela Organização das Nações Unidas para o Desenvolvimento Industrial (UNIDO). Estes documentos foram ressaltados nesta pesquisa por apontarem temas e questões norteadores para o desenvolvimento do modelo conceitual para a produção do açaí.

Do mesmo modo, a Declaração de Ahmedabad colaborou para o entendimento da importância da valorização das características existentes nos países em desenvolvimento e do poder da ciência e da tecnologia no empreendimento de estratégias de desenvolvimento econômico com ênfase no setor industrial.

Apesar destes documentos estarem voltados ao desenvolvimento industrial para os países em desenvolvimento, suas recomendações são pertinentes para o design sustentável em geral.

Além desses documentos, outros autores contribuíram para a fundamentação do modelo conceitual para a produção do açaí que foi elaborado, Por exemplo Sachs, com suas recomendações para se ouvir os moradores da floresta e aprender com eles como conservar o meio ambiente e fazer uso dos recursos renováveis, respeitando os limites da natureza, foi bastante importante. O autor aponta que os moradores devem elaborar suas estratégias de uso produtivo e se beneficiar com suas próprias ideias, proclamando o modelo endógeno.

A partir do resultado deste estudo, concluímos que um modelo conceitual para a produção do açaí implica em complexas atividades. Porém, estas são ações factíveis, que podem partir da iniciativa privada como também da iniciativa 
pública. O modelo pode ser reaplicado, com as devidas adaptações, em outras localidades do estado do Amazonas.

Este trabalho resultou de uma avaliação minuciosa, de uma investigação e da transformação dos conhecimentos e informações coletados. Neste sentido, se apresenta como uma contribuição para a literatura acerca da região, favorecendo o desenvolvimento da agroindústria regional. Por tratar-se de um exemplo de modelo conceitual para a produção do açaí, espera-se, também, que o estudo funcione como um referencial, capaz de mobilizar a continuidade e o aprimoramento de pesquisas nesta área, por acadêmicos, designers e profissionais de áreas correlatas. Espera-se, ainda, que os resultados alcançados tenham justificado a realização da pesquisa.

Finalmente, pretende-se que a proposta de um modelo conceitual para a produção do açaí contribua para o desenvolvimento econômico da região, com ênfase na sustentabilidade e na responsabilidade social. Neste contexto, fica evidente o ganho ambiental e socioeconômico para as comunidades ribeirinhas e para a agroindústria do Estado do Amazonas. 


\section{Glossário}

Paneiro - Cesto de vime com asas. Segundo o Novo Dicionário da Língua Portuguesa. Editora Nova Fronteira. Rio de Janeiro. 1975.

Peconha - Laço de corda ou de embira preso ao tronco das árvores sem ramos, para nele se colocarem os pé a fim de subir. Segundo Novo Dicionário da Língua Portuguesa. Editora Nova Fronteira. Rio de Janeiro. 1975.

Ráquila - Eixos primários das inflorescências (cacho). No caso específico do açaizeiro, são os ramos do cacho onde se fixam os frutos. http://minhasfrutas.blogspot.com.br/2008/12/glossario-do-aa.html 


\section{Referências Bibliográficas}

ACSELRAD, Henri. Sustentabilidade e articulação territorial do desenvolvimento brasileiro. In: Seminário Internacional sobre Desenvolvimento Regional. Santa Cruz do Sul, RS. 2004.

ALBIERO, Daniel; MACIEL, Antonio José da Silva; MION, Renildo Luiz, VILIOTTI, Carlos Alberto; Gamero, Carlos Antonio. Proposta conceitual de colhedoras autopropelidas de açaí (Euterpe oleracea Mart.) para a Região Amazônica. Revista Ciência Agronômica, v. 43, n. 2. ISSN 1806 6690. 2012.

Associação Brasileira de Ciclo de Vida (ABCV). Copyright (c) 2013. http://www.abcvbrasil.org.br/o-que-e-acv.php

Associação Brasileira de Normas Técnicas. NBR 14810-1 - Chapas de madeira aglomerada, Terminologia. Rio de Janeiro: ABNT, Março, 2002.

NBR 14810-2 - Chapas de madeira aglomerada, Requisitos. Rio de Janeiro: ABNT, Março, 2002.

. NBR 14810-3 - Chapas de madeira aglomerada, Métodos de ensaio. Rio de Janeiro: ABNT, Março, 2002.

Associação Brasileira de Normas Técnicas. NBR 6502 - Rochas e solos Terminologia de 1995,

BACELLAR, Atlas A.; SOUZA, Rubem C. R.; XAVIER, Diogo J. C.; SEYE, Omar; SANTOS, Eyde C. S.; FREITAS, Katriana T. Geração de Renda na Cadeia Produtiva do Açaí em Projeto de Abastecimento de Energia Elétrica em Comunidades Isoladas no Município de Manacapuru-Am. 
2006. Artigo do Centro de Desenvolvimento Energético Amazônico CDEAM, Universidade Federal do Amazonas - UFAM.

BECKER, Bertha K. Geopolítica da Amazônia. Estudos Avançados. 2005.

BONSIEPE, Gui. Design: como prática de projeto. Editora Edgard Blücher Ltda. São Paulo. 2012.

CARVALHO, Mônica Maranha Paes de. Design sustentável ou social? Como os designers que fazem projetos para inclusão social e desenvolvimento sustentável caracterizam seu trabalho. Dissertação de Mestrado. Pontifícia Universidade Católica do Rio - PUC - Rio. Rio de Janeiro. 2012.

CERVO, Amado Luiz; BERVIAN, Pedro Alcino. Metodologia Científica. $5^{\underline{a}}$ Edição. São Paulo: Prentice Hall, 2002.

CIPINIUK, Alberto; PORTINARI, Denise B; BOMIM, Gustavo Amarante. COELHO, Luiz Antonio L. (Org.) Conceitos-chave em design. Rio de Janeiro. Ed. PUC-Rio Novas Ideias. 2008.

CHITARRA, M. I. F. Pós-colheita de frutos e hortaliças: fisiologia e manuseio. Lavras: ESAL/FAEPE, 1990. 320 p.

DHAL, Debajani; PATTNAIK, Binay Kumar. ATDA. Hand Washing Machine. Appropriate Technology Development Association Lucknow. India. 1977.

EEA, European Environment Agency. Life Cycle Assessment - A guide to approaches, experiences and information sources. Bruxelas, Bélgica. 1997.

EICHENBERG, Carolina Hermes; REYES, Paulo Edison Belo. INOVAÇÃo SOCIAL: arquitetura da rede ideia. Rio Grande do Sul. 2014. 
ELESBÃO, Ivo; SOUZA, Marcelino de; KLEIN, Ângela Luciane.Temáticas emergentes em Turismo Rural. Funções educativas do turismo rural pedagógico: o Projeto "Turismo Rural e Escola - Fazendo Eco" no Distrito Federal. São Paulo. 2014.

FARIAS NETO, João Tomé de; MÜLLER, Carlos Hans; MÜLLER, Antonio Agostinho; CARVALHO, José Edmar Urano de carvalho; VIÉGAS, Ismael de Jesus Matos. Sistema de Produção do Açaí (Cultivar e produção de mudas). Embrapa Amazônia Oriental; Sistemas de Produção; Num. 04; ISSN1809-4325 Versão Eletrônica; Belém, PA. 2006.http://sistemasdeproducao.cnptia.embrapa.br/FontesHTML/Acai/Siste maProducaoAcai_2ed/paginas/apresentacao.htm. Acesso em: 20 de setembro 2014.

FRASCARA, Jorge. Comunicação para mudança: estratégias e dificuldades. Arcos Design 5, 2009.

Design and the social sciences. Making connections. Taylor \& Francis. London. 2002.

GIL, Antonio Carlos. Como elaborar projetos de pesquisa. $5^{\underline{a}}$ Edição. São Paulo. Editora Atlas S.A, 2010.

GAUDIO, Chiara Del; OLIVEIRA, Alfredo Jefferson de; FRANZATO, Carlo. O Tempo do Design Participativo. Congresso Brasileiro de Pesquisa e Desenvolvimento em Design: $11^{\circ}$ Pesquisa e Desenvolvimento Design - 11 P\&D Design. Gramado, Rio Grande do Sul, 2014.

GUIMARÃES, Luiz Eduardo Cid; DANTAS, Leiliam Cruz. Participatory Design: Possibilities of Interventions for Low-Income Populations Northeast - Brazil. XIV International Conference on Industrial Engineering and Operations Management. The integration of productive chain wit an approach to sustainable manufacturing. Rio de Janeiro. 2008. 
HEISKANEN, E. The institutional logic of life cycle thinking. Journal of Cleaner Production 10, p. 427-437. Elsevier Science Ltd. 2002.

HOMMA, Alfredo Kingo Oyama. Sistema de Produção do Açaí (Colheita e pós-colheita). Embrapa Amazônia Oriental; Sistemas de Produção; Num. 04; ISSN1809-4325 Versão Eletrônica; Belém, PA; Dezembro, 2006.

HOMMA, Alfredo Kingo Oyama; CARVALHO, José Edmar Urano de Antônio; MENEZES, José Elias Amorim de; FARIAS NETO, João Tomé de; MATOS, Grimoaldo Bandeira de. Custo Operacional de Açaizeiro Irrigado com Microaspersão no Município de Tomé-Açu. Embrapa Amazônia Oriental; ISSN 1983-0505 Versão Eletrônica; Belém, PA. 2009.

HOMMA, Alfredo Kingo Oyama; Nogueira, Oscar Lameira; Menezes, Antônio José Elias Amorim de; Carvalho, José Edmar Urano de; Nicoli, Clarisse Maia Lana; Matos, Grimoaldo Bandeira de. Açaí: novos desafios e tendências. Amazônia: Ciência \& Desenvolvimento. Belém, v. 1, n. 2. 2006.

MACHADO, Lia Osório. Urbanização e mercado de trabalho na Amazônia Brasileira. Cadernos IPPUR.1999.

MARTINS, Maria Alice; MATTOSO, Luiz Henrique Capparelli; PESSOA, José Dalton Cruz. Rev. Comportamento Térmico e Caracterização Morfológica das Fibras de Mesocarpo e Caroço do Açaí (Euterpe Oleracea Mart.). Bras. Frutic., Jaboticabal - SP, v. 31, n. 4, p. 1150-1157, 2009.

MANZINI, Ezio. Design para a inovação social e sustentável: comunidades criativas, organizações colaborativas e novas redes projetuais. Rio de Janeiro: E-papers, 2008. (Cadernos do Grupo de Altos Estudos; v. 1). 
MARGOLIN, Victor. Design e a situação mundial. Design Issues v.12. n. 2. 1996.

Um Modelo Social de Design: questões de prática e pesquisa. Revista Design em Foco, vol. I, núm. 1, 2004. Universidade do Estado da Bahia, Bahia, Brasil.

Poíticas do artificial: ensaios e estudos sobre o design. Editora José Olympio LTDA. Rio de Janeiro. 2014

"Design para o desenvolvimento: mapeamento do contexto". PATROCÍNIO, Gabriel; NUNES, José Mauro (org.) Design e Desenvolvimento: 40 anos depois. editora Edgard Blücher Ltda. São Paulo. 2015.

MÜLLER, Antonio Agostinho. Sistema de Produção do Açaí (Ambiente edafo climático). Embrapa Amazônia Oriental; Sistemas de Produção; Num. 04; ISSN1809-4325 Versão Eletrônica; Belém, PA; Dezembro, 2006.

MÜLLER, Carlos Hans; MÜLLER, Antonio Agostinho; CARVALHO, José Edmar Urano de carvalho; VIÉGAS, Ismael de Jesus Matos. Sistema de Produção do Açaí (Cultivo do açaizeiro em terra firme). Embrapa Amazônia Oriental; Sistemas de Produção; Num. 04; ISSN1809-4325 Versão Eletrônica; Belém, PA; Dezembro, 2006.

NOGUEIRA, Oscar Lameira. Sistema de Produção do Açaí (Cultivo de açaizeiro em várzea). Embrapa Amazônia Oriental; Sistemas de Produção; Num. 04; ISSN1809-4325 Versão Eletrônica; Belém, PA; Dezembro, 2006.

OLIVEIRA, Alfredo Jefferson de. Eco-Design e remanufatura: algumas contribuições para o projeto de produto eco-eficiente. Tese (Doutorado em Engenharia de Produção), Universidade Federal do Rio de Janeiro: COPPE/UFRJ, 2000. 
OLIVEIRA Jr., Aristides da R.; MACHADO, José Alberto da C. O Polo Industrial de Manaus e sua Dinâmica. Curitiba, Paraná, 2009.

PAPANEK, Victor. Design for the Real World. Great Britain.Thames \& Hudson Ltda. 1972.

PATROCÍNIO, Gabriel; NUNES, José Mauro. Design e Desenvolvimento: 40 anos depois. Editora Edgard Blücher Ltda. São Paulo. 2015.

PAZMINO, Ana Verónica. Uma reflexão sobre Design Social, Eco Design e Design Sustentável. I Simpósio Brasileiro de Design Sustentável. Curitiba, Paraná, 2007.

PESSOA, José Dalton; ALMEIDA, Gustavo Henrique de. Tecnologias para inovação nas cadeias euterpe. Teixeira editores. Brasília, DF: Embrapa, 2012.

Portal Brasil. http://www.brasil.gov.br/economiaeemprego/2014/08/zonafranca-de-manaus-esta-oficialmente-prorrogada-ate-2073 Acesso: 11/9/2015.

QUIRINO. Magnólia Grangeiro. Estudo de matriz polimérica produzida com resina natural e fibra da semente de açaí (Euterpe precatoria). Dissertação (Mestrado em Engenharia Civil), Universidade Federal do Amazonas, Manaus, 2010.

RIOS, Layana. SUFRAMAHOJE. Informativo da SUFRAMA. Ano XIV. Edição 73. Março 2015.

ROSE, Catherine Michelle. Design for Environment: a method for formulating product end-of-life strategies. A dissertation submitted to the department of mechanical engineering and the committee on graduate studies of Stanford University in partial fulfillment of the requirements for the degree of Doctor of Philosophy. 2000. 
SACHS, Ignacy. Caminhos para o desenvolvimento sustentável. Rio de Janeiro. Garamond. 2009.

SANTOS, Milton. A Natureza do Espaço: Técnica e Tempo, Razão e Emoção. 4. ed. São Paulo: Editora da Universidade de São Paulo, 2006.

A urbanização brasileira. São Paulo: Editora da Universidade de São Paulo, 2008.

SUFRAMA 48 Anos. Disponível: http://www.fazpartedasuavida.com.br Acesso em: 12 maio 2015.

VASCONCELOS, Marcus Arthur Maçal de; ALVES, Sérgio de Melo. Sistema de Produção do Açaí (Colheita e pós-colheita). Embrapa Amazônia Oriental; Sistemas de Produção; Num. 04; ISSN1809-4325 Versão Eletrônica; Belém, PA; Dezembro, 2006.

VIANA, Virgílio M. Envolvimento Sustentável e Conservação Das Florestas Brasileiras. Ambiente \& Sociedade.1999.

YAMANAKA, Eric Seiti. Cultivo, extração e beneficiamento do açaí orgânico. 2012. Dossiê Técnico. Universidade Estadual Paulista SIRT/UNESP. 
9

\section{Apêndices}

Apêndice 1 - Entrevistas realizadas com a presidente da Cooperativa de Açaí de Codajás, a senhora Franciani Sobreira da Silva.

Quatro entrevistas foram realizadas com a senhora Franciani Sobreira da Silva. Todas tiveram roteiros estruturados. As informações contidas nestas entrevistas foram colocadas no corpo da tese. As entrevistas foram feitas presencialmente e por mensagens telefônicas. Todas as entrevistas foram realizadas em forma de perguntas diretas. 


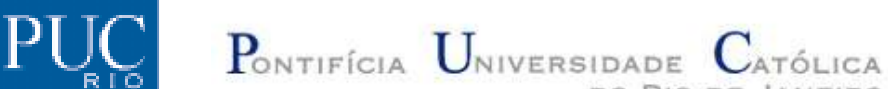 DO RIO DE JANEIRO}

Pontifícia Universidade Católica do Rio de Janeiro - PUC-Rio

Departamento de Artes e Design

Programa de Pós-Graduação em Design

Primeira entrevista realizada com a Sra. Franciani Sobreira da Silva.

Título: Uma proposta de modelo conceitual para a produção do açaí no estado do Amazonas.

Pesquisadora: Magnólia Grangeiro Quirino.

Orientadora: Prof. ${ }^{a}$ Dra. Luiza Novaes e coorientador Prof. Dr. Fernando Betim Paes Leme.

A primeira entrevista faz parte da coleta de dados a respeito da cadeia produtiva do açaí, realizada no município de Codajás. A entrevista com a presidente da Cooperativa de Açaí de Codajás, Sra. Franciani Sobreira da Silva, foi conduzida por meio de perguntas e respostas, presencialmente. As perguntas foram agrupadas de acordo com os seguintes temas: Cooperativa de Açaí de Codajás; extrativistas; colheita do açaí; debulhamento; transporte, despolpamento e comercialização.

\section{Cooperativa de Açaí de Codajás}

1. Qual o nome da presidente da Cooperativa de açaí de Codajás?

Franciani Sobreira da Silva.

2. Há quanto tempo você exerce esta função?

Faz um ano. Minha atuação como presidente da Cooperativa iniciou no ano de 2014.

3. Quem era responsável pela gestão anterior da Cooperativa?

Foi o José Vieira de Oliveira.

4. Por que saiu o antigo presidente da Cooperativa?

Porque expirou o tempo para o exercício da presidência. 
5. De quem foi a iniciativa de formar uma cooperativa?

Foram os agricultores que perceberam seu potencial agrícola e recorreram ao poder público para montar a cooperativa.

\section{Em que ano surgiu a Cooperativa de Açaí de Codajás?}

A Cooperativa de açaí de Codajás, compreende um prédio projetado para atender o beneficiamento do fruto do açaí, foi fundada no ano de 2002. O prédio foi construído em 2004 e as atividades iniciaram no ano seguinte, no ano de 2005.

\section{A Cooperativa é iniciativa pública ou privada?}

A Cooperativa é pública.

8. Quantos cooperativados fazem parte da cooperativa?

São setenta e seis cooperativados.

\section{Qual a média de idade dos cooperativados?}

Os cooperativados tem entre sessenta a setenta anos de idade.

10. Como é a divisão de trabalho?

Os agricultores são os cooperativados. Eles exercem as atividades no campo.

Os processadores são terceirizados, exercem as atividades na Cooperativa são responsáveis pelo processamento e beneficiamento da polpa do açaí.

\section{Como é a divisão de lucro?}

Cada cooperativado recebe pelo que vende, ou seja, sua produção diária.

12. O que é necessário fazer para participar da cooperativa?

São os agricultores de açaí do município que buscam a Cooperativa e seguem os critérios do Estatuto da Cooperativa. Não existe um regimento interno destinado para a Cooperativa.

13. Após a criação da Cooperativa foi feita alguma benfeitoria na estrutura física do prédio da Cooperativa?

Não. São dez anos de existência da Cooperativa de Açaí de Codajás e nunca foi feito nenhuma benfeitoria. 
14. Ocorrem cursos de profissionalização na Cooperativa?

Há dois anos atrás, no ano de 2013, foi promovido cursos pelo Serviço Brasileiro de Apoio às Micro e pequenas Empresas - SEBRAE e pela Organização das Cooperativas do Brasil - OCB.

15. Quais foram os cursos?

Cooperativismo e Associativismo; Conselheiro Fiscal e Administrativo; Beneficiamento do Açaí; e Saber Empreender.

16. Quais as dificuldades da Cooperativa?

São várias dificuldades, mas a principal é a financeira: os clientes desvalorizam o preço. Outras dificuldades são: a paralisação das atividades na entressafra, a concorrência com a agroindústria vinda do Pará e por fim, a falta de apoio dos próprios cooperativados junto com a senhora Franciani.

\section{Existe apoio governamental?}

Nenhum.

18. Em que aspecto?

Sem resposta, porque não existe apoio, os cooperativados operam por conta própria.

19. Qual a ligação da Cooperativa com os extrativistas?

Os cooperativados são os extrativistas.

\section{Extrativistas}

\section{Quantos extrativistas são?}

São setenta e seis extrativistas (cooperativados).

2. Quantas propriedades fornecem o fruto?

O mesmo número de cooperativados: são setenta e seis extrativistas (cooperativados).

\section{Qual a idade média dos extrativistas?}

Os extrativistas (cooperativados) tem entre sessenta a setenta anos de idade. 
4. Que horas começam a escalar o açaizeiro?

O escalador começa a escalar às seis horas e termina às dezessete horas e trinta minutos.

5. Quantos cachos são retirados por dia?

São retirados de seis a sessenta cachos por dia.

6. Qual o preço médio de venda de uma saca?

O preço médio de uma saca de cinquenta quilos custa sessenta reais.

7. Existe um modo mais simples de retirar os cachos?

Com a peconha.

8. Existe uma maneira mais simples de debulhar os frutos?

Com as mãos dedilhando uma ráquila cada vez, em seguida, bate os cachos na lona de plástico.

9. Como é a divisão do trabalho?

Cada cooperativado colhe em sua propriedade os frutos maduros.

10. Como é a divisão do lucro?

Cada cooperativado recebe pelo o que vende, produção diária.

11. Você conhece o "Pente debulhador"?

Não.

12. Funciona bem?

Não sei responder.

\section{Colheita do açaí}

1. Quanto tempo existe a prática da exploração comercial do açaí, aqui em Codajás?

Não sei responder. 
2. Com que idade se aprende a escalar o açaizeiro, existe uma idade para escalar (tempo cronológico)?

Entre oito a dez anos de idade.

3. Quem ensinou a escalar nas palmeiras?

Foram os pais.

4. Quais os artefatos utilizados para a escalada?

A peconha.

5. Entre a peconha produzida com fibras naturais e a peconha improvisada com saco de nylon, qual é a melhor peconha e por que?

A peconha improvisada com saco de nylon porque, as fibras naturais apodrecem.

6. Ocorrem acidentes na escalada do açaizeiro?

Sim. Com poucos registro de acidentes.

7. Que tipo de acidentes?

Quedas.

8. Os acidentes são considerados rotineiros (formigas no corpo), leves (arranhões no corpo), medianos (necessitam intervenção farmacêutica) ou graves (necessitam intervenção hospitalar)?

Os acidentes são considerados rotineiros (formigas no corpo) e leves (arranhões no corpo).

8. Existem quedas que levam à morte do escalador?

Sim. Casos raros.

9. Existe estímulo para os jovens ou crianças para escalar as palmeiras?

Desconheço.

10. Existe campeonato ou disputas nas festividades para apreciar a escalada? Não.

11. Conhece algum artefato que possa realizar a colheita do açaí?

Terçado (facão) e a peconha são utilizados em Codajás. 
A vara com um gancho na extremidade conheço por meio de comunicação: televisão e internet.

12. Conhece o "Equipamento e Métodos para a Colheita de Cachos de Frutas" (PI 0803992-5)? Funciona Bem?

Sim. Não sei se funciona bem, vi na televisão.

13. É possível a substituição de um novo artefato para a escalada?

Sim, é possível a substituição de um novo artefato para a escalada. Porém, até o momento desconheço outro artefato além da peconha.

14. Em caso positivo à substituição, é considerado como uma perda dos costumes e tradição da comunidade?

Acredito que não.

15. Quantos açaizeiros são escalados por dia?

Os cooperativados escalam de quinze a trinta açaizeiros por dia.

16. O que poderia ser feito com segurança para o escalador no sentido de realizar a colheita do açaí?

Adaptação da vara com o cinto de segurança para o escalador.

17. Qual sua opinião ou sugestão a respeito de escalar o açaizeiro? É uma atividade perigosa.

\section{Debulhamento}

1. Existem artefatos para debulhar o açaí dos cachos?

Não.

2. Quais os artefatos utilizados para debulhar o açaí dos cachos?

Nenhum. O debulhamento é feito manualmente.

3. Conhece o "Pente debulhador" dos cachos de açaizeiro? Não. 
4. O que fazem com as ráquilas?

Uma pequena porção é utilizada para o artesanato.

5. Existem malefícios para a saúde humana provocada pelo debulhamento? Sim.

6. Quais são estes males?

Calos nas mãos.

7. O que poderia ser feito com segurança para o debulhador retirar os frutos dos cachos?

O uso de luva.

8. Qual sua opinião ou sugestão a respeito do debulhamento?

Criar um artefato que agilize o debulhamento.

\section{Transporte}

1. Onde são colocados os frutos após o debulhamento?

Os frutos depois do debulhamento são colocados nas sacas.

2. Entre a rasa e a caixa de plástico qual é o mais utilizado? E por que?

São as caixas de plástico conhecidas como basquetas. As caixas são mais resistentes do que as rasas.

3. Quem produz as rasas?

Desconheço.

4. Quais são as fibras das rasa?

Desconheço.

5. Quem ensinou a tecer as rasas?

Desconheço. 
6. Com que idade se aprende a tecer as rasas, existe idade para aprender a tecer as rasas (tempo cronológico)?

Desconheço.

7. Como é realizado o carregamento das rasas até o transporte (rodoviário ou fluvial)?

O carregamento das basquetas é feito com a força física.

8. O que poderia ser feito para realizar este carregamento?

Não sei responder.

\section{Despolpamento}

1. Quantas sacas são despolpada por dia?

Aproximadamente, duzentas e cinquenta sacas por dia.

2. Quais são os meses da safra do açaí?

A safra do estado do Amazonas corresponde do mês de janeiro ao mês de junho (seis meses). A safra do estado do Pará inicia no mês de julho e vai até o mês de janeiro.

3. Como é a divisão do trabalho?

Cada cooperativado debulha o açaí que retira da sua propriedade.

\section{Comercialização}

1. Quem é o responsável pela comercialização?

A senhora Franciani.

2. Como é a divisão do lucro?

A presidente compra a produção dos cooperativados e depois vende a polpa de açaí, em seguida paga as despesas da Cooperativa.

3. Quem são os compradores da polpa?

Os maiores compradores são os clientes da cidade de Manaus. 
4. A polpa é exportada? Para onde?

A polpa foi exportada. Para o Canadá e os Estados Unidos no ano de 2006 e 2007.

5. Desde quando vocês exportam?

As exportações foram finalizadas, ocorridas apenas no ano de 2006 até 2007. 
Pontifícia Universidade Católica do Rio de Janeiro - PUC-Rio

Departamento de Artes e Design

Programa de Pós-Graduação em Design

Segunda entrevista realizada com a Sra. Franciani Sobreira da Silva.

Título: Uma proposta de modelo conceitual na produção do açaí para o estado do Amazonas.

Discente: Magnólia Grangeiro Quirino.

Orientadores: Prof. Dra. Luiza Novaes e coorientador Prof. Dr. Fernando Betim Paes Leme.

A segunda entrevista realizada com a presidente da Cooperativa de Açaí de Codajás, Sra. Franciani Sobreira da Silva, foi conduzida por mensagens telefônicas. Faz parte da coleta de dados a respeito do modelo produtivo do açaí. Trata das atividades realizadas no campo.

1. Na propriedade visitada o plantio é nativo ou manejado?

O plantio é manejado.

2. Quantos hectares tem a propriedade visitada?

A propriedade visitada tem quatro hectares.

3. Qual a distância entre os açaizeiros, entre as palmeiras (aproximadamente)? A distância entre os açaizeiros correspondem a cinco metros.

4. Quantos cachos são debulhados por dia, por cada cooperativado?

São debulhados de seis a sessenta cachos por dia, pois em uma saca de cinquenta quilos cabem seis cachos.

5. Quantas sacas cada cooperativado faz por dia?

Cada cooperativado faz de uma saca a dez sacas. 
6. Quantos cachos são retirados por açaizeiro em um dia?

São retirados de um a dois cachos por palmeira, pois nem todos amadurecem ao mesmo tempo.

\section{Quantos açaizeiros os cooperativados escalam por dia?}

Os cooperativados escalam de quinze a trinta açaizeiros por dia, pois se o fruto estiver verde eles escalam até mais para conseguirem tirar uma quantidade de sacas que atinja a média estimada entre seis e sessenta cachos. 


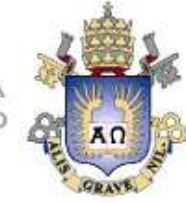

\section{Pontifícia Universidade Católica do Rio de Janeiro - PUC-Rio \\ Departamento de Artes e Design \\ Programa de Pós-Graduação em Design}

Terceira entrevista com a Sra. Franciani Sobreira da Silva.

Título: Uma proposta de modelo conceitual na produção do açaí para o estado do Amazonas.

Discente: Magnólia Grangeiro Quirino.

Orientadora: Prof. ${ }^{\text {a }}$ Dra. Luiza Novaes e coorientador Prof. Dr. Fernando Betim Paes Leme.

A terceira entrevista realizada com a presidente da Cooperativa de Açaí de Codajás, Sra. Franciani Sobreira da Silva, foi conduzida por mensagens telefônicas. A entrevista faz parte da coleta de dados a respeito do período da safra do açaí.

\section{Safra de janeiro a agosto de 2016.}

1. Quando se encerra seu mandato de presidente da Cooperativa de Açaí de Codajás?

Meu mandato se encerra em outubro de 2016.

Iniciou no ano de 2014 e finaliza em 2016. O mandato de presidente da Cooperativa de Açaí de Codajás compreende a dois anos.

2. No período da safra do ano de 2016 (janeiro a agosto) ocorreu algum curso motivacional para os jovens ou para os cooperados?

Infelizmente, não ocorreu nenhum curso. Apesar da carência de cursos motivacionais ou similares não foi ofertado nenhum curso.

3. Ocorreu algum curso técnico sobre a produção do açaí, no período da safra do ano de 2016 (janeiro a agosto)?

Não. 
4. Como foi a safra de açaí este ano de 2016 ?

A safra foi boa, deu bastante açaí.

\section{Como foi o funcionamento da Cooperativa?}

Este ano a Cooperativa não funcionou.

6. Qual o motivo do não funcionamento da Cooperativa?

Os motivos do não funcionamento da Cooperativa foram decorrentes dos problemas mencionados anteriormente.

7. A fábrica de beneficiamento do açaí que iria se instalar em Codajás funcionou neste período da safra?

Sim. Agora na cidade de Codajás existe uma nova fábrica de beneficiamento do açaí, filial da cidade de Belém - PA.

\section{Como foi a produção de açaí?}

Foi muito boa. A fábrica de beneficiamento do açaí de Belém instalada na cidade de Codajás não deu conta da produção de açaí. Estragou muitos frutos dos diversos agricultores da região, inclusive os frutos dos nossos cooperativados.

\section{Existe alguma iniciativa para a próxima safra?}

Acredito que o próximo presidente irá tomar uma providência a respeito. No mês de outubro encerra meu mandato de presidente na Cooperativa encerra também minha responsabilidade com a Cooperativa de Açaí de Codajás.

10. Existe algum órgão, entidade, instituição e ou indivíduo que possa colaborar com informações a respeito do universo do açaí?

Sim, no momento lembro de dois nomes: o primeiro é o da Sra. Diane Sobreira da Silva, a vice-presidente da Cooperativa de Crédito Rural e Economia Solidária de Codajás - CODCRED e o outro é o do Secretário de Cultura de Codajás, o Sr. Ebenézer de Alencar Bastos. 


\section{Pontifícia Universidade Católica do Rio de Janeiro - PUC-Rio \\ Departamento de Artes e Design \\ Programa de Pós-Graduação em Design}

Quarta entrevista com a Sra. Franciani Sobreira da Silva.

Título: Uma proposta de modelo conceitual na produção do açaí para o estado do Amazonas.

Discente: Magnólia Grangeiro Quirino.

Orientadores: Prof. Dra. Luiza Novaes e coorientador Prof. Dr. Fernando Betim Paes Leme.

A quarta entrevista realizada com a presidente da Cooperativa de Açaí de Codajás, Sra. Franciani Sobreira da Silva, foi conduzida presencialmente e abordou a da Festa do Açaí, realizada no município de Codajás.

1. Existe algum decreto de lei que oficializa a Festa de Açaí de Codajás?

Sim. O Decreto de Lei 003/88. Este Decreto oficializa a festa e acata dois dias de feriado para as escolas municipais de Codajás e um dia para o banco.

2. A festa movimenta economicamente o município?

Sim. Alguns comerciantes dos municípios circunvizinhos trazem seus produtos para venderem no período da festa.

3. Quais são os produtos comercializados?

São vendidos produtos alimentícios: polpa de açaí, frutas, legumes, hortaliças, pescado e carne de sol; são vendidos também produtos de artesanato feitos com os resíduos do açaizeiro: sementes, ráquilas, partes do tronco, folhas, fibras e fofoia. 
4. Após a festa do açaí ocorre desenvolvimento de técnicas e de equipamentos que facilitem o processo produtivo do açaí?

Sim. Em 2007, houve uma certa inquietação por parte dos cooperados para resolver as transações financeiras, então a partir deste ano, foi cogitado o desenvolvimento de um novo empreendimento que solucionasse este problema. No ano de 2012, surgiu a CODCRED, uma Cooperativa de Crédito Rural e Economia Solidária de Codajás. Esta cooperativa surgiu com o objetivo de facilitar as negociações financeiras dos comerciantes de açaí.

\section{Após a festa do açaí ocorre motivação empresarial?}

"Não. A cidade morre" (segundo Sra. Franciani).

Os comerciantes, em sua maioria, são dos municípios vizinhos. Eles vendem seus produtos e quando vão embora levam consigo o dinheiro, ou seja, os moradores de Codajás não são beneficiados com os produtos comercializados na Festa do Açaí.

Ocorre uma significativa venda de produtos alimentícios como a carne de sol, mas o lucro não fica no município. Do mesmo modo, acontece com as camisetas que são comercializadas durante o evento. Elas são produzidas fora, vendidas em Codajás e o lucro desta comercialização vai junto com o comerciante. 
Apêndice 2 - Entrevistas realizadas com o Secretário de Cultura de Codajás, o Sr. Ebenézer de Alencar Bastos.

Foram realizadas quatro entrevistas. Todas tiveram roteiros estruturados. As informações contidas nestas entrevistas foram colocadas no corpo da tese. As entrevistas com o Sr. Ebenézer de Alencar Bastos foram feitas por correio eletrônico. Todas as entrevistas foram realizadas em forma de perguntas diretas. 


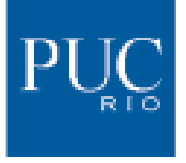

Pontifícia

$\mathrm{U}_{\text {NIVERSidade }} \mathrm{C}_{\text {atólica }}$

DO RIO DE JANEIRO

\section{Pontifícia Universidade Católica do Rio de Janeiro - PUC- Rio \\ Departamento de Artes e Design \\ Programa de Pós-Graduação em Design}

Primeira entrevista com o Sr. Ebenézer de Alencar Bastos.

Título: Uma proposta de modelo conceitual na produção do açaí para o estado do Amazonas.

Discente: Magnólia Grangeiro Quirino.

Orientadora: Prof. ${ }^{\text {a }}$ Dra. Luiza Novaes e coorientador Prof. Dr. Fernando Betim Paes Leme.

A primeira entrevista com o Secretário de Cultura de Codajás, o Sr. Ebenézer de Alencar Bastos, faz parte da coleta de dados a respeito da Festa do Açaí, que acontece anualmente no município de Codajás. A entrevista foi realizada pelo correio eletrônico e transcrita com alguns ajustes. Esta seção abrangeu os aspectos gerais da festa.

1. Sr. Ebenézer, qual sua função na Secretaria de Educação e Cultura do município de Codajás?

Secretário Municipal de Cultura.

2. Há quanto tempo você exerce esta função?

Três anos e oito meses, desde o ano de 2013 até agosto de 2016 (data em que foi realizada a pesquisa, em 24 de setembro de 2016).

3. Qual a data da festa de açaí de Codajás?

A primeira Festa do Açaí de Codajás - FAC, chamada semana cultural do açaí, foi programada para ter início no dia 09 de abril de 1988, segundo as prévias entrevistas, visitas de campo, contagem das sacas embarcadas para Manaus, a capital do estado, para se ter ideia mínima de quantidade e junto a outros parâmetros utilizados pelo idealizador da festa com vários 
colhedores/apanhadores de frutos e produtores de "vinho" de açaí e compradores/vendedores de açaí em sacas; balateiros, seringueiros etc. chegouse a conclusão que a primeira quinzena de abril era o período de maior pico de colheita do fruto do açaizeiro nos arredores da cidade, vistas as alterações nas micros regiões circunvizinhas.

Contudo, hoje, o usual é aproveitar os finais de semanas junto aos feriados de 21 de abril ou 01 de maio.

O Decreto Lei é de 08 de abril (alterado para 16) de 1988, pelo então prefeito Nathan da Silva Bastos tendo como o idealizador o tecnólogo Adoniron Nelson Bastos Rodrigues.

\section{Esta data tem alguma relação com a safra do açaí?}

Sim, o maior pico de produção é a primeira quinzena de abril.

\section{Quem são as pessoas que organizam a festa?}

A festa cultural do açaí é um grandioso evento realizado pela prefeitura através da

Secretaria Municipal de Cultura com a participação direta das escolas das redes municipal e estadual, dos comunitários e entidades locais.

\section{Qual o público alvo da festa?}

A população geral do município e visitantes de diversos lugares. A festa representa para o povo um momento de aconchego, visita aos parentes locais, congraçamento e entre os estudantes mobiliza a disputa da sua candidata ao título de "Garota açaí".

\section{A festa atrai turistas?}

Sim. Não temos estatísticas, mas chegam a centenas de turistas.

\section{Os turistas são de outro estado?}

Também, mas são principalmente das cidades vizinhas e da capital do estado.

\section{Quais os veículos de divulgação da festa?}

Televisão, rádio, jornal, folders, cartazes, pessoas, etc.

\section{A festa movimenta economicamente o município?}

Sim, é a segunda maior referência econômica do município. 
11. Quais os benefícios ou incentivos que a festa promove para a cultura do açaí? É um evento tradicionalmente importante na perpetuação da cultura. Surgiu em virtude da observação do idealizador quanto ao volume da produção, escoamento diário e o embrionário plantio, sobretudo pela fama de grandes feitores e tomadores do açaí então chamado sangue de boi ou "vinho" simplesmente; além da belíssima apresentação folclórica dos trajes típicos da eleição anual da (musa) garota açaí o que já nos deu tamanha fama - quiçá. 


\section{Pontifícia Universidade Católica do Rio de Janeiro - PUC- Rio \\ Departamento de Artes e Design \\ Programa de Pós-Graduação em Design}

Segunda entrevista com o Sr. Ebenézer de Alencar Bastos.

Título: Uma proposta de modelo conceitual na produção do açaí para o estado do Amazonas.

Discente: Magnólia Grangeiro Quirino.

Orientadora: Prof. ${ }^{a}$ Dra. Luiza Novaes e coorientador Prof. Dr. Fernando Betim Paes Leme.

A segunda entrevista faz parte da coleta de dados a respeito da Festa do Açaí, realizada no município de Codajás. A entrevista foi realizada com o Secretário de Cultura, o Sr. Ebenézer de Alencar Bastos, enviada pelo correio eletrônico e transcrita com alguns ajustes. Esta seção abrangeu os aspectos culturais da festa.

1. Quais as atrações da festa?

As atrações são em maioria de artistas locais e regionais com apenas uma atração nacional (banda ou cantor).

2. Como foi a programação cultural e musical?

Normalmente se divide em duas partes:

a) Cultural propriamente dita (concursos de poesias, músicas, danças, etc.);

b) Seminários, gastronomia, sociabilidade, etc.

3. Como foi o Seminário do Açaí?

Os seminários tem sido ótimos, contudo seus efeitos são lentos e graduais. Os palestrantes são convidados dos mais diversos órgãos. 
4. Quem promoveu o Seminário do Açaí?

A Prefeitura Municipal com suas secretarias afins e em parceria com o IDAM, EMBRAPA e outras empresas pesquisadoras ou produtoras de açaí.

\section{Qual a finalidade do Seminário do Açaí?}

Promover a real sustentabilidade com qualificação e equalização do sistema de produção, higienização e conservação desta palmeira (Euterpe precatoria) que é endêmica por nossa característica climática e que se torna economicamente especial para os codajaenses.

6. Em que local foi realizada a exposição de artesanato?

Em torno do Centro Cultural de nossa cidade.

\section{Os expositores foram locais?}

Sim, em sua grande maioria. Foram poucos expositores de fora. 


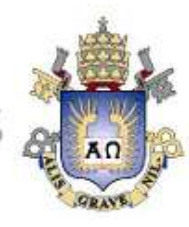

\section{Pontifícia Universidade Católica do Rio de Janeiro - PUC-Rio Departamento de Artes e Design Programa de Pós-Graduação em Design}

Terceira entrevista com o Sr. Ebenézer de Alencar Bastos.

Título: Uma proposta de modelo conceitual na produção do açaí para o estado do Amazonas.

Discente: Magnólia Grangeiro Quirino.

Orientadora: Prof. ${ }^{a}$ Dra. Luiza Novaes e coorientador Prof. Dr. Fernando Betim Paes Leme.

A terceira entrevista com o Secretário de Cultura de Codajás, Sr. Ebenézer de Alencar Bastos, faz parte da coleta de dados a respeito da Festa do Açaí que acontece no município de Codajás. A entrevista foi realizada pelo correio eletrônico e transcrita com alguns ajustes. Esta seção atendeu à necessidade de esclarecimentos adicionais sobre algumas questões mencionadas em entrevistas anteriores.

1. Existe algum decreto de lei que oficializa a festa de açaí de Codajás? Sim. O Decreto de Lei 003/88.

2. Na entrevista anterior foi feita a pergunta: A festa movimenta economicamente o município? Cuja resposta foi: Sim, é a segunda maior referência econômica do município. Com base nesta resposta suscita a seguinte questão: Qual a primeira referência econômica do município?

Por estimativa, o pescado é a primeira referência econômica de Codajás.

3. Quais foram os temas dos seminários ministrados durante a festa do açaí? No ano de 2015, foram realizados dois seminários: o primeiro seminário foi sobre a Assistência Técnica viabilizado pela Secretaria de Produção do Município; e o secundo seminário abordou a respeito do Cadastro Ambiental Rural - CAR 
promovido pelo Instituto de Desenvolvimento Agropecuário e Florestal do Amazonas - IDAM.

4. Quem foram os beneficiados diretos com os seminários?

Produtores: plantadores (donos de sítios); colhedores: tiradores e peconheiros; feitores (batedores) de vinho (suco) de açaí.

5. Os seminários proporcionam inovações tecnológicas para o processo produtivo do açaí?

Sim. Porém, em pequena escala direcionado para o aproveitamento das sementes. 


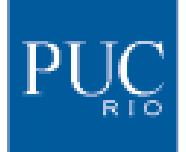

Pon

$\mathrm{U}$

DO RIO DE JANEIRO

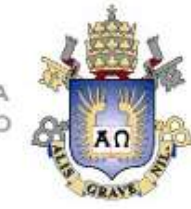

\section{Pontifícia Universidade Católica do Rio de Janeiro - PUC-Rio \\ Departamento de Artes e Design \\ Programa de Pós-Graduação em Design}

Quarta entrevista com o Sr. Ebenézer de Alencar Bastos.

Título: Uma proposta de modelo conceitual na produção do açaí para o estado do Amazonas.

Discente: Magnólia Grangeiro Quirino.

Orientadora: Prof. ${ }^{\text {a }}$ Dra. Luiza Novaes e coorientador Prof. Dr. Fernando Betim Paes Leme.

A quarta entrevista realizada com o Secretário de Cultura de Codajás, Sr. Ebenézer de Alencar Bastos, faz parte da coleta de dados a respeito da Festa do Açaí, que acontece no município de Codajás. A entrevista foi enviada pelo correio eletrônico e transcrita com alguns ajustes. Esta seção abrangeu a necessidade de esclarecimentos adicionais sobre algumas questões mencionadas em entrevistas anteriores.

1. Os seminários promoveram desenvolvimento de técnicas e de equipamentos que facilitem o processo produtivo do açaí?

Sim, esse é o objetivo. Existe trabalho acadêmico local visando a higienização do produto, pois naturalmente ele esconde impureza.

2. Após a festa do açaí ocorre motivação empresarial?

Sim, é sempre um incentivo para o crescimento do processo produtivo existente.

3. Após a festa do açaí surge novos investidores no processo produtivo do açaí? Sim. Uma empresa de médio porte já se instalou na cidade e produz quinhentas toneladas por safra.

4. Surge novos colhedores/apanhadores e compradores/vendedores de açaí? Sim, e desperta novos compradores em função da demanda, sempre crescente. 
5. Qual o sentimento dos envolvidos no processo produtivo do açaí, com o término da festa?

Bom. Confraternização, integração inter municipal, desenvolvimento cultural, entre outros.

6. Qual o sentimento dos munícipes de Codajás com relação ao processo produtivo do açaí, com o término da festa?

O sentimento dos munícipes de Codajás é de segurança econômica, de perspectiva futura, de inovação, entre outros. 
Apêndice 3 - Entrevistas realizadas com a vice-presidente da Cooperativa de Crédito Rural e Economia Solidária de Codajás - CODCRED, a Sra. Diane Sobreira da Silva.

Foram realizadas duas entrevistas. Todas tiveram roteiros estruturados. As informações contidas nestas entrevistas foram colocadas no corpo da tese. As entrevistas com a Sra. Diane Sobreira da Silva foram feitas presencialmente. Todas as entrevistas foram realizadas em forma de perguntas diretas, reproduzidas a seguir. 


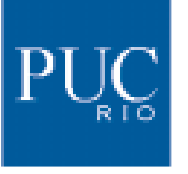

Pontificia

$\mathrm{U}_{\mathrm{N}}$

IVERSIDADE DO RIO DE JANEIRO

\section{Pontifícia Universidade Católica do Rio de Janeiro - PUC- Rio \\ Departamento de Artes e Design \\ Programa de Pós-Graduação em Design}

Primeira entrevista com a Sra. Diane Sobreira da Silva.

Título: Uma proposta de modelo conceitual na produção do açaí para o estado do Amazonas.

Discente: Magnólia Grangeiro Quirino.

Orientadora: Prof. ${ }^{\text {a }}$ Dra. Luiza Novaes e coorientador Prof. Dr. Fernando Betim Paes Leme.

A primeira entrevista realizada com a Sra. Diane Sobreira da Silva, a vicepresidente da Cooperativa de Crédito Rural e Economia Solidária de Codajás CODCRED. Esta seção abrangeu a questão de transações bancárias para os cooperativados da Cooperativa de Açaí de Codajás.

1. Em que ano surgiu a Cooperativa de Crédito Rural e Economia Solidária de Codajás - CODCRED?

A CODCRED foi fundada no dia 23 de fevereiro do ano de 2012, pelos seguintes organizadores: Sr. José Brito, Sra. Marlene Andrade, Sra. Maria Nézia e Sr. Antonio Ferreira (in memoriam).

\section{Como surgiu a CODCRED?}

Um grupo de pessoas preocupadas em solucionar o problema do pagamento dos agricultores recorreu ao SEBRAE que acenou a formação de uma cooperativa de crédito. A partir de 2007, este grupo de organizadores realizaram várias reuniões e visitas em outras cooperativas do Paraná e de Minas Gerais, com o propósito de entender como funcionava uma cooperativa de crédito e como trabalhar com o sistema financeiro, uma atividade bastante diferente da que eles estavam habituados, as pessoas envolvidas eram agricultores não estavam familiarizados com movimentações bancárias. 


\section{Qual a finalidade da CODCRED?}

A finalidade da CODCRED é auxiliar as negociações financeiras realizadas através das comercializações do açaí feitas pelos agricultores.

O único banco existente em Codajás é o BRADESCO que possui restrições de pagamento aos agricultores, limitando um valor máximo de pagamento em $R \$$ 2.000,00 (dois mil reais). Acima deste valor deve ser aguardado três dias para resgatar o pagamento. Este procedimento adotado pelo Bradesco é inviável para a demanda dos agricultores que almejam receber o pagamento logo que finalizam a venda. Não só almejam, como necessitam do pagamento para suprir as necessidades alimentares da sua família.

\section{Qual a outra finalidade da CODCRED?}

Outra finalidade é atender as pessoas que exercem atividades esporádicas relacionadas com a produção do açaí e não tem como comprovar a atividade, como por exemplo, um serviço de limpeza do açaizal, uma pessoa que realiza este tipo de serviço muitas vezes não faz parte do processo produtivo do açaí. Então, a CODCRED viabilizou um documento que facilite o pagamento para atividades temporárias.

\section{Quais os problemas que a CODCRED enfrentou?}

No ano de 2012 foi fundada a Cooperativa de Crédito Rural e Economia Solidária de Codajás autorizada pelo Banco Central. No ano seguinte, houve um atraso nos serviços decorrente da inexperiência dos organizadores com o sistema bancário. Novamente, o SEBRAE entra em cena e orienta a buscar auxílio com a CREDISOL.

\section{O que é CREDISOL?}

A CREDISOL é uma Instituição de Crédito Solidário criada no ano de 1999 por iniciativa da Agência de Fomento de Santa Catarina S.A. - BRADESCO com apoio técnico do SEBRAE para facilitar o acesso ao crédito para pessoas que trabalham por conta própria, mesmo que ainda na informalidade. Significa acesso ao crédito de forma simples e a oportunidade de receber orientação técnica gratuita para fortalecer o seu negócio. O Ministério da Justiça qualifica a CREDISOL como Organização da Sociedade Civil de Interesse Público - OSCIP, conforme o endereço eletrônico: http://www.credisol.org.br/quem-somos (acesso 18/10/2016). 


\section{Pontifícia Universidade Católica do Rio de Janeiro - PUC- Rio \\ Departamento de Artes e Design \\ Programa de Pós-Graduação em Design}

Segunda entrevista com a Sra. Diane Sobreira da Silva.

Título: Uma proposta de modelo conceitual na produção do açaí para o estado do Amazonas.

Discente: Magnólia Grangeiro Quirino.

Orientadora: Prof. ${ }^{\text {a }}$ Dra. Luiza Novaes e coorientador Prof. Dr. Fernando Betim Paes Leme.

A segunda entrevista realizada com a Sra. Diane Sobreira da Silva, a vicepresidente da Cooperativa de Crédito Rural e Economia Solidária de Codajás CODCRED. Esta seção abrangeu a conexão entre a CODCRED e a Instituição de Crédito Solidário, a CREDISOL; e a questão de empréstimos para os cooperativados da Cooperativa de Açaí de Codajás.

\section{Qual o objetivo da CREDISOL?}

A CREDISOL orienta a expansão da CODCRED no sentido de abrir outras filiais e aumentar a oferta de serviços para a comunidade.

Será ministrado um seminário em novembro de 2016 para esclarecer os requisitos que devem ser atendidos e as metas para prospecção de ampliação da CODCRED.

2. Quais os benefícios promovidos pela CREDISOL?

A partir da CREDISOL foi feito uma compra de um trator e um arado para a Cooperativa de Açaí.

A CREDISOL também facilita o financiamento individual aos agricultores para a compra de máquinas do tipo roçadeira.

Existe um caso de sucesso com uma cooperada que fez um financiamento para adquirir uma máquina que tritura as sementes do açaí e produz ração para sua 
criação de animais (porcos e galinhas). A máquina facilitou seu trabalho no campo e com a venda dos animais a cooperada está conseguindo pagar o financiamento. Todos estes benefícios obtidos pelo intermédio da CREDISOL estão na fase inicial de conversa, acreditamos que com a formalização da parceria os benefícios serão maiores e até extensivos para o município de Codajás.

\section{Qual é o limite de crédito?}

Em 2014 começamos com o limite máximo de crédito de $R$ \$1.500,00 (hum mil e quinhentos reais), atualmente, a CODCRED tem um limite máximo de $R \$$ $4.000,00$ (quatro mil reais).

\section{Qual a abrangência da clientela da CODCRED?}

Atendemos aos agricultores, piscicultores e produtores da zona rural, conforme o estatuto da CODCRED.

A CODCRED não consegue atender as pessoas que não tem meios legais de comprovar sua atividade profissional, como por exemplo, cabeleleiro, manicure, mototaxista, trabalhador braçal, entre outros.

\section{Qual o posicionamento do Banco Central perante a atuação da CODCRED?}

O Banco Central cobrou uma expansão da Cooperativa de crédito. Mas a CODCRED respondeu que o seu tímido progresso está amparado nos princípios do estatuto, que de certo modo, limita a clientela da CODCRED, como foi comentado anteriormente. Um outro motivo é corresponder com a documentação atualizada perante as auditorias do Banco Central, desse modo, a CODCRED possui uma clientela e um progresso restritos. 
10.

Anexos

Anexo 1:

Organização das Nações Unidas para o Desenvolvimento Industrial

Distr.

Restrito

UNIDO/ITD.180

18 de abril 1973 


\section{ORGANIZAÇÃO DAS NAÇÕES UNIDAS PARA O DESENVOLVIMENTO INDUSTRIAL \\ Distr. RESTRITO \\ UNIDO/ITD.180 \\ 18 de abril 1973}

ISENÇÃO DE RESPONSABILIDADE: As opiniöes expressas neste documento são exclusivas do seu autor e não refletem necessariamente a visão da Organização das Nações Unidas para o Desenvolvimento Industrial. (Como estabelecido pela Circular Administrativa UNIDO/DA/PS/AC.69 de 17 de dezembro de 1990). Este documento foi reproduzido sem edição formal. 
Sumário

Prefácio

Notas históricas

Descrição do design industrial

De interpretações orientadas pela arte a interpretações orientadas pela tecnologia

0 núcleo do design industrial

Condições tecnológicas para o design industrial

Áreas de produtos do design industrial

0 que o design indústrial não é

Design industrial e profissões limítrofes

Sua relação com engenharia mecânica e marketing

Sua relação com outros campos de design

Design de artes $\mathrm{e}$ artesanato

Design industrial e sua importância para os países em desenvolvimento

Possíveis campos de atuação do design industrial em países em desenvolvimento

Algumas regras gerais para políticas de design industrial

0 papel específico do design industrial em países em desenvolvimento

A situação nos paises industrializados

A abordagem diferente do design industrial em países em desenvolvimento

Definições para grupos de design industriais em desenvolvimento

Promoção do design industrial

Informações

Apoio logístico à promoção e à informação do design

Formação de designers industriais

Design industrial em programas de assistência técnica

0 papel do ICSID

\section{Anexo: Estudos de Caso ${ }^{1}$}

Design de uma máquina de semeadura agricola

Design de mobiliário de baixo custo

Design de uma embalagem de ovos para 0 atacado

Design de uma marmita

Design de uma caixa de correio

Design de equipamentos para jardins de infância

Exterior de uma calculadora eletrônica de mesa

Conjunto de porcelanas econômico

Toca-discos

Caixa de plástico para o transporte de frutos do mar

Sala de operação para um MIS (sistema de gerenciamento de informação) 


\section{Prefácio}

Este artigo foi elaborado em fevereiro de 1973, a fim de servir de base para a discussão entre os representantes da UNIDO e do ICSID.

As ideias e propostas expressas no presente documento não pretendem refletir uma opinião oficial, nem do ICSID nem de qualquer outra instituição ou grupo de designers industriais. $\mathrm{O}$ autor considerou as orientações dadas pela UNIDO no que se refere aos itens que este documento deve abranger e à sua finalidade: servir como um "abridor de olhos".

$\mathrm{O}$ autor tentou dar um relato do papel que o design industrial poderia desempenhar como fator de desenvolvimento nos paises em desenvolvimento.

Hste artigo é baseado em uma experiência de cinco anos de trabalho como designer industrial em paises da América Latina, parte dos quais foi sob contrato de uma agência internacional. Além disso, houve publicações consultadas que lidam com o assunto "design industrial/paises em desenvolvimento/desenvolvimento".

Existem hoje opiniões diferentes (refletindo diferentes interesses) sobre o papel que a indústria pode e deve desempenhar nos países em desenvolvimento. Como nenhuma opinião pode fingir que possui validade universal, o autor fez uso do direito de apresentar um ponto de vista que pode defender e que considera fazer justiça aos interesses dos paises em desenvolvimento.

\section{Notas históricas}

Como profissão, o desenho industrial tornou-se reconhecido há cerca de duas geraçōes, quando, pela primeira vez, cursos universitários nesta especialidade foram oferecidos na Europa e nos Estados Unidos.

Como atividade, no entanto, remonta ao século XIX, quando a industrialização começou a mudar a fisionomia do mundo material.

Como ferramenta para o desenvolvimento, especialmente a promoção das exportaçōes, seu papel foi reconhecido no início da primeira década deste século.

Como ferramenta de marketing, passou a ser usado no início dos anos 1930.

Como área de promoção governamental, estabeleceu-se em meados dos anos 1940.

\section{Descrição do design industrial}

(a) De interpretações orientadas pela arte a interpretações orientadas pela tecnologia Uma interpretação de desenho industrial é como um casamento entre arte e tecnologia ou arte e indústria. Essa interpretação mostra as dificuldades que surgem quando um novo acontecimento é explicado em termos de fenômenos já existentes, conhecidos. Ela não dá informaçōes suficientes sobre o caráter do design industrial para que se possa chamá-lo de uma mistura de arte e tecnologia. 
Em seus primórdios, ao design industrial, que não era chamado por esse nome, foi atribuida a tarefa de embelezar produtos industriais feios. Arte (com letra maiúscula) era vista como uma força "civilizatória" para a indústria (brutal).

De acordo com outra opinião, o design industrial pode ser explicado como um resultado do fracasso das profissões de engenharia; supondo que os engenheiros não possuem nem sensibilidade estética nem a capacidade de síntese, isto é, de ver o produto em seu conjunto. Enquanto o designer industrial é visto como um indivíduo especialmente dotado, cuja tarefa consiste em coordenar os esforços de outros profissionais. Essa opinião não tem base empírica e resulta de uma ilusão. Ela tem causado desconfiança justificada entre industrialistas e tecnólogos e não pode ser considerada um argumento adequado para introduzir o design industrial na indústria.

Os já citados pareceres salientam em excesso os aspectos estéticos e culturais do design industrial, negligenciando outros aspectos tão ou ainda mais importantes, tais como valor de uso, produtividade e inovação tecnológica.

$\mathrm{Na}$ história do design industrial, pode-se observar a mudança de interpretações orientadas pela arte para interpretações orientadas pela tecnologia, e até mesmo pela ciência.

(b) 0 núcleo do design industrial

$\mathrm{O}$ design industrial está estreitamente entrelaçado com e dependente do contexto socioeconômico em que é exercido. Portanto, é imprudente tentar formular uma definição universalmente aceita de design industrial. Pode existir um acordo geral sobre o que o designer industrial está fazendo, mas a discordância que pode surgir quanto à pergunta "para quê?" tem de ser resolvida. O método e o conteúdo desta atividade podem ser bastante semelhantes em diferentes partes do mundo onde o design industrial formou bases; os objetivos, por outro lado, serão diferentes.

No entanto, no decurso das duas últimas décadas, têm sido propostas diversas formulações de design industrial que coincidem em certos traços da atividade e que podem formar um ponto de encontro para um consenso geral.

O design industrial centra-se em torno dos seguintes tópicos:

(i) Está preocupado com a melhoria da usabilidade de produtos industriais, elemento integrante de sua qualidade geral. Do ponto de vista do design industrial, um produto é, em primeiro lugar, um objeto que oferece certos serviços, satisfazendo assim às necessidades do usuário.

(ii) Está preocupado com as "propriedades formais" de produtos industriais. Características formais referem-se a toda a aparência de um produto, incluindo sua configuração tridimensional, sua "fisionomia", sua textura e 
sua cor. (O termo "formal" é preferivel ao termo "estético", sendo mais descritivo do que avaliador.)

(iii) Trata-se de uma atividade inovadora. Ê um tipo especial de inovação tecnológica.

(iv) Está preocupado com a comerciabilidade do produto no que se refere a seu mercado de vendas, tanto em termos de fornecimento de matérias-primas como de demanda do produto.

\section{(c) Condiçōes tecnológicas para o design industrial}

$O$ design industrial está ligado à satisfação de necessidades, na medida em que tais necessidades podem ser satisfeitas por estruturas fisicas convencionalmente chamadas de "produtos". A fim de ser capaz de satisfazer a essas necessidades individuais, coletivas ou de grupo, o design industrial pressupōe uma tecnologia de produção (máquinas, materiais, mão de obra, métodos de organização industrial, técnicas de gestăo) e uma tecnologia de distribuição (marketing incluindo análise de necessidades, diversificação de produtos, publicidade, politica de sortimento, avaliação de produção, embalagem). Sem essas duas tecnologias, o design industrial não pode existir.

\section{(d) Áreas de produtos do design industrial}

Embora o designer industrial lide com inovação de produto, não é em toda variedade da produção industrial que ele se envolve. A divisão - emprestada da economia - entre bens de consumo e bens de capital não serve para fins de design industrial. $\mathrm{O}$ fator decisivo que determina quando e onde o design industrial poderia e deveria participar difere entre as taxonomias de produto existentes.

O núcleo do design industrial é formado por aqueles produtos em que exista uma interação operativa perceptiva e/ou operacional direta entre o usuário e 0 objeto.

Por essa razảo, o design industrial é de pouca importância quando o problema de design consiste no design de um cabo transoceânico - embora seja evidente que esse é um produto industrial.

Pela mesma razão, o design industrial é chamado ou deveria ser chamado quando o problema se encontra em um dos seguintes:

$$
\begin{aligned}
& \text { um assento de trator, } \\
& \text { um arado, } \\
& \text { uma ferramenta, } \\
& \text { um aparelho de cozinha, } \\
& \text { um instrumento médico, } \\
& \text { uma fonte de luz, }
\end{aligned}
$$


um recipiente de leite,

um pacote de alimento,

um dispositivo para conservação de alimento,

um equipamento de transporte,

um brinquedo,

um componente para casas pré-fabricadas,

um dispositivo para fins educativos,

- para nomear apenas alguns produtos.

As qualidades de uso desse espectro tão amplo de produtos são determinadas por uma série de fatores, tais como:

conforto,

simplicidade de uso,

durabilidade,

funcionalidade,

segurança,

facilidade de limpeza,

facilidade de manutenção e reparaçăo.

Esses fatores estão relacionados aos custos, que dependem de fatores tecnológicos, tais como:

montagem simples,

grau de padronização,

tolerâncias,

utilização do método de produção correto,

utilização do material correto,

acabamento.

\section{(e) 0 que o design industrial não é}

Diante dessas observações, uma conclusão pode ser estabelecida sobre o que o design industrial não é.

$O$ design industrial não é apenas envolver com novas formas agradáveis, atraentes e elegantes produtos (supostamente) feios.

$\mathrm{O}$ design industrial não é cirurgia plástica.

$O$ design industrial não é simplificação.

O design industrial não é tornar "sexy" antigas formas fora de moda. 
É claro, o design industrial pode ser tudo isso, e seria ingenuidade ignorar ou negar que ele é praticado nesse sentido. Mas essa orientação não é adequada para paises em desenvolvimento, e é altamente questionável em países industrializados (desperdício de recursos, crise ecológica).

\section{Design industrial e profissöes limitrofes}

\section{(a) Sua relação com engenharia mecânica e marketing}

O design industrial não é apenas uma atividade multidisciplinar, mas também é interdisciplinar, ou seja, é uma atividade realizada em interaçẫo direta, e não apenas em paralelo, com outras disciplinas envolvidas no processo de design. Salvo em raros casos (produtos de baixa complexidade), näo é só o designer industrial que projeta o produto, em esplêndido isolamento, podendo ser considerado como a única autoridade responsável pelo design.

$\mathrm{O}$ produto industrial, ao contrário dos produtos artesanais, resulta de um trabalho em equipe, com a participaçăo de um variado número de outras profissōes, incluindo profissões de design como engenharia mecânica.

Os vizinhos profissionais diretos do design industrial, especialmente no caso de produtos mais complexos, são a engenharia mecânica e a engenharia de produção, de um lado, e o marketing, do outro. Todos esses profissionais influenciam no design final de um produtó. Os designers industriais compartilham núcleos - como foi mencionado anteriormente - em torno das qualidades de uso, incluindo as qualidades formais dos produtos.

A divisão de funções entre "designer de entranhas" e "designer de pele" é errada e enganadora, pois nẫo existe uma clara linha divisória entre o interior e o exterior de um produto industrial. Estrutura e forma representam, ou deveriam representar, um todo coerente, e não uma mistura de componentes separados, muitas vezes incompativeis entre si.

A diferença entre design industrial e engenharia mecânica não é vista quanto ao método (arte versus ciência), mas sim quanto à ênfase colocada em certos aspectos do problema de design. O designer industrial lida predominantemente com aspectos não quantificáveis da soluçäo do problema de design.

\section{(b) Sua relação com outros campos de design}

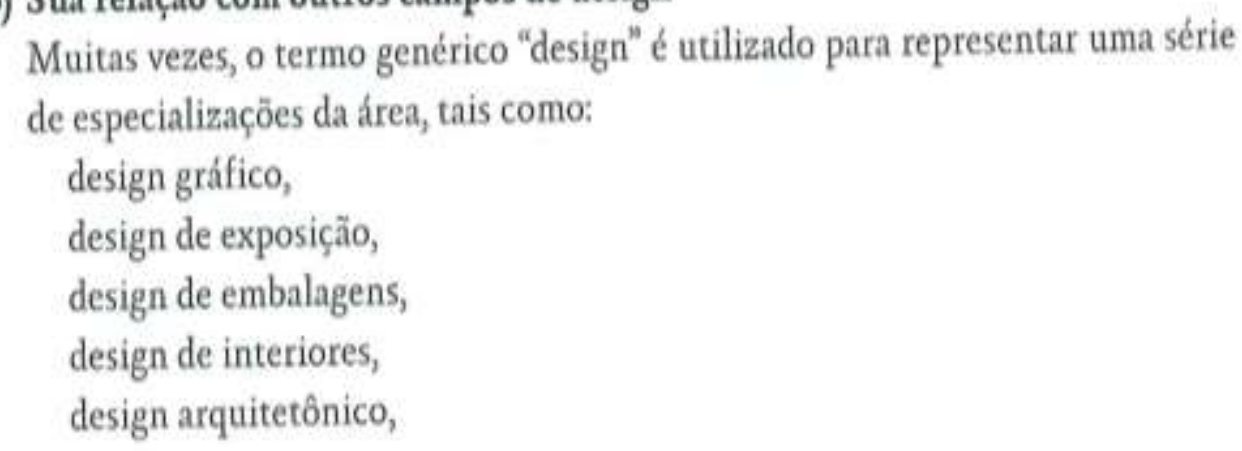


design de moda,

design de artes e artesanato (e artesanato com base em design).

$\mathrm{O}$ design de interiores é uma disciplina independente. $\mathrm{O}$ mesmo se aplica para arquitetura, design gráfico e design de moda.

$O$ design de embalagens fica na fronteira entre design gráfico, que se ocupa das informações bidimensionais da embalagem, e design industrial, que é o responsável por forma tridimensional, fechamento, empilhamento etc, da embalagem. $\mathrm{Na}$ verdade, escritórios de design industrial muitas vezes lidam com design de embalagem, e o ICSID considera a embalagem como parte do design industrial.

Assim, embora o design industrial esteja principalmente preocupado com essas duas áreas, design de produto e design de embalagem, há zonas intermediárias de atuação, tais como design de componentes arquitetônicos, que é um campo onde design industrial e arquitetura se mesclam, e design de exposição, que é muitas vezes visto como parte da atividade de design industrial.

\section{(c) Design de artes e artesanato}

$O$ design de artes e artesanato é muitas vezes, especialmente nos países em desenvolvimento sem infraestrutura tecnológica, considerado como precursor ou etapa preparatória do design industrial e, por vezes, até mesmo identificado como a entidade completa de desenho industrial. A última assunção é falsa.

Há uma distinta diferença entre design de artes e artesanato e design para indústrias artesanais. $\mathrm{O}$ primeiro refere-se à fabricação parte por parte, em áreas como cerâmica, tecelagem, tecelagem com cana e junco, joias e artigos de couro, com meios tecnológicos e organizaçẩo de trabalho simples. Enquanto o segundo refere-se especialmente a porcelana e têxteis, produzidos em escala industrial, com máquinas e organização de trabalho específicas. Esses produtos podem ser incluídos sob o título "design industrial", mas seria um erro tratar o design de artes e artesanato como única e principal estratégia para países em desenvolvimento. $\mathrm{O}$ potencial de desenvolvimento do design de artes e artesanato é bastante limitado. A industrialização é, precisamente, uma forma de superar os métodos de fabricação artesanais, e permanecer nesse nível leva a um autoinfligido corte nas possibilidades de desenvolvimento.

\section{Design industrial e sua importância para os países em desenvolvimento}

$O$ design industrial deve ser usado como uma ferramenta no processo de industrialização dos paises em desenvolvimento. De fato, ele constitui um instrumento indispensável para esforços rumo ao desenvolvimento.

Sua importância - e a necessidade de formular uma política de design nos países em desenvolvimento - é baseada no fato de que ele pode ajudar a resolver os seguintes problemas: 
(i) Economias dependentes contam com a importação de bens manufaturados (bens de capital, bens de consumo e bens de serviço social para hospitais e escolas). Essas importações exercem uma influência negativa sobre a já distorcida balança de pagamentos. Ao desenvolver e produzir seus próprios designs, países em desenvolvimento podem alocar suas reservas em divisas e seus rendimentos para fins produtivos, ou seja, direcionar esses recursos financeiros para a criação de uma diversificada infraestrutura tecnológica.

(ii) Produtos criados em países desenvolvidos não necessariamente se adequam aos requisitos $e$ às necessidades dos países em desenvolvimento. Por essa razão, é imperativo que os países em via de desenvolvimento comecem a criar produtos próprios, que correspondam às suas necessidades especificas e que possam ser fabricados com a ajuda da tecnologia existente, ou de tecnologia que não requeira grandes investimentos de capital, e de preferência com matérias-primas locais.

(iii) Nos países em desenvolvimento, um dos problemas mais urgentes a resolver é a criação de empregos, a fim de integrar a população em atividades produtivas. $\mathrm{O}$ design industrial nos países em desenvolvimento poderia ser direcionado para a elaboração de produtos que utilizam mão de obra intensiva, em vez de produtos de capital intensivo, que caracterizam a tendência dos países industrializados. Isso é importante, pois o mercado de trabalho local tem uma carência de mão de obra qualificada nos países manufatureiros.

(iv) Em geral, países em desenvolvimento sofrem com o fato, entre outros, de que suas economias não são diversificadas, e muitas vezes a capacidade de produção das indústrias transformadoras não é totalmente utilizada, por falta de projetos inovadores. $\mathrm{O}$ design industrial pode ajudar a promover a plena utilização das instalações de produção e diversificar a produção industrial.

(v) O design industrial como um tipo de inovação tecnológica é um meio muito eficaz para a promoção das exportações. Os projetos desenvolvidos internamente com caráter inovador possuem um potencial de exportação, especialmente nas regiões onde acordos comerciais entre diversos países têm sido estabelecidos, particularmente onde o design de produto tem sido orientado pelo mercado.

(vi) Os produtos industriais ou, em termos antropológicos, artefatos materiais constituem uma porção cada vez maior do meio ambiente criado pelo homem. Eles são a expressão de uma cultura. Cada nação tem, em maior ou menor grau, sua própria identidade cultural. No que diz respeito aos produtos industriais formarem parte de uma cultura, o design 
industrial pode ajudar a criar esta identidade, superando o estado de cultura de segunda mäo dos países em desenvolvimento.

(vii) Não parece existir uma lei ou um padrão histórico que a industrialização e o desenvolvimento devam seguir. Pelo contrário, a crise ecológica provocada pela tecnologia dos paises "desenvolvidos" coloca em questão a justificativa de chamar essas tecnologias de "desenvolvidas". Embora o design industrial esteja menos preocupado com a criação de novas tecnologias do que com a utilização das tecnologias para satisfazer a determinadas necessidades, ele pode, ainda assim, estimular o desenvolvimento de outras tecnologias compativeis com o ambiente.

(viii) Distribuição de renda é também um dos graves e explosivos problemas dos paises em desenvolvimento. Muitas vezes, a maioria da populaçăo se encontra excluída do acesso a produtos industriais porque estes estão além do alcance de suas possibilidades financeiras. $O$ design industrial poderia encontrar um de seus mais nobres objetivos, e uma de suas poucas justificativas que realmente valem a pena, no desenvolvimento de produtos para atender às necessidades das maiorias pobres.

(ix) Países em desenvolvimento precisam utilizar seus recursos limitados de uma forma otimizada, com o mínimo desperdício possivel. Eles não estäo bem aconselhados quando copiam estilos de vida e variedades de produtos dos paises industrializados. Confrontada com a inegável escassez de meios, a formulação de políticas de produtos e a definição de prioridades tornam-se necessárias; priorizar quais necessidades serão satisfeitas em primeiro lugar, e quais necessidades serão satisfeitas em uma fase posterior de maior desenvolvimento, com um nivel mais elevado de produtividade. Racionalização e formulação de politicas de diversificação de produtos podem se tornar algumas das principais áreas de design industrial nos países em desenvolvimento.

O design industrial é, portanto, importante para os países em desenvolvimento, pois ele pode ajudar a resolver nove problemas básicos:

1. Aliviar a balança de pagamentos.

2. Satisfazer a requisitos específicos e necessidades do mercado relevante.

3. Criar novos empregos.

4. Diversificar a produção industrial.

5. Criar mercados de exportação.

6. Criar identidade cultural.

7. Estimular o desenvolvimento de tecnologias alternativas.

8. Responder às necessidades das maiorias.

9. Racionalizar a saída da produção industrial. 
V. Possiveis campos de atuaçĩo do design industrial em países em desenvolvimento Embora, na opiniāo pública geral, o design industrial esteja em grande medida associado a bens de consumo, existem muitas áreas de produto nas quais designers industriais podem tornar-se, e já são, ativos.

Estas áreas incluem por exemplo:

equipamento para transporte de passageiros (bicicletas, ônibus, trens), transporte de carga (caminhões),

equipamentos de saúde (salas de operaçâo móveis para zonas rurais, instrumentos cirúrgicos),

material escolar (mobiliário escolar, equipamento pré-escolar, brinquedos educativos),

máquinas e ferramentas agrícolas,

componentes para construção de habitações de baixo custo,

ferramentas e máquinas para indústrias médias e leves,

embalagens de produtos alimentares, bem como métodos de distribuição $\mathrm{e}$ conservação de alimentos,

móveis para habitações de baixo custo,

bens de consumo duráveis de todos os tipos.

\section{Algumas regras gerais para políticas de design industrial}

Quando um país em desenvolvimento começa a trabalhar nos campos acima mencionados - lista que năo pretende ser exaustiva -, pode ser útil ter em mente as seguintes observações sobre uma política de design:

(i) Realizar atividade de design industrial nos paises em desenvolvimento não significa desenvolver réplicas baratas ou versões de baixa qualidade de designs existentes, desenvolvidos nos países industrializados. Em vez disso, ela requer uma definição e uma soluçăo do problema de design em termos de meios (escassos) e necessidades (abundantes) existentes.

(ii) A atividade de design em países em desenvolvimento näo deveria derivar seus padrōes de avaliaçâo dos países industrializados; mas extrair seus pontos de referência a partir de sua própria realidade. Só essa realidade pode produzir padrōes de avaliação dos esforços em design feitos por países em desenvolvimento.

(iii) Em geral, não seria viável visar a uma autarquia completa do design nos países em desenvolvimento. Portanto, torna-se necessário estabelecer prioridades para os projetos de design ou áreas de design de acordo com seus benefícios sociais globais e seu potencial de desenvolvimento (efeito multiplicador). 
(iv) Quando se exercita a transferência de design como um tipo de transferência de tecnologia, podem-se seguir duas estratégias:

a) $\mathrm{O}$ design estrangeiro importado é adaptado para as possibilidades tecnológicas dos países em desenvolvimento, sem sacrificar as qualidades de usabilidade. Essa adaptação exige uma reformulação levando em conta os recursos tecnológicos e os parâmetros. Máquinas, materiais, nível de execução, tolerâncias possíveis, mão de obra, o volume de produção existente ou alcançável no país em questão. O objetivo é reproduzir um design estrangeiro com os recursos existentes, o que requer modificaçōes. Por causa da reformulação, a ideia da cópia rápida e fácil de designs estrangeiros é uma ilusão.

b) $\mathrm{O}$ design estrangeiro importado é adaptado para os requisitos funcionais e as necessidades específicas dos paises em desenvolvimento. Essa adaptação implica uma nova formulação de especificações de desempenho, e pode levar a grandes modificações do design existente, e até mesmo ao desenvolvimento de um novo produto.

É importante observar que, em ambos os casos, o design estrangeiro serve de ponto de partida, e não, como em uma mera cópia, de ponto final. $\mathrm{Na}$ adaptação de designs, o país adaptador precisa criar uma capacidade para trabalho inovador que ajude a reduzir o seu estado de dependência. Essa prática é o oposto da transferência de tecnologia reprodutiva, caso das licenças ou regimes de royalties.

(v) A transferência de design na forma de informação ou conhecimento prático, especialmente em metodologia de design, deveria ser feita de forma flexível, ou seja, a informação dos países industrializados deve ser adaptada às necessidades $\mathrm{e}$ às contingências dos países em desenvolvimento, $\mathrm{e}$ não vice-versa. Caso contrário, o conhecimento em design tende a se tornar imposto a uma realidade que não pode assimilar os conhecimentos transferidos. A transferência de design sem modificações, tanto em equipamento quanto em informações, dos paises industrializados para os países em desenvolvimento é praticamente impossivel, e causaria efeitos contraproducentes.

(i) Países em desenvolvimento que querem utilizar o design industrial como uma estratégia para o desenvolvimento necessitam atribuir prioridade máxima à formação de recursos de mão de obra local nas áreas de: gestão do design, pesquisa em design, projetos de design. 
A segunda prioridade refere-se ao apoio logístico, especialmente a equipamentos de oficinas de protótipo e a laboratórios, com mecanismos adequados e equipamentos de escritórios de design.

\section{A diferença específica no papel do design industrial nos países em desen- volvimento e nos países industrializados}

(a) A situação nos paises industrializados

Em geral, o design industrial nos países industrializados tem à sua disposição tecnologia sofisticada, com uma grande variedade de materiais, processos de fabricação e mäo de obra especializada. Além disso, existe uma estrutura de mercado altamente diversificada, com uma grande variedade de preferências sutis do consumidor.

A taxa de obsolescência, tanto tecnológica quanto psicológica, é geralmente muito alta. Nessas "economias de abundầncia", o design industrial tem uma participação decisiva na criação de inovaçäo formal (estética, visual), especialmente em bens de consumo - um papel cada vez mais criticado por um número crescente de membros da profissão. Essa atitude crítica defende que a inovação formal, com sua alta rotatividade de mercadorias, tem de ser repensada por consideraçôes ecológicas, para não mencionar as consideraçōes sociais.

Assim, as empresas e organizações corporativas nos paises industrializados utilizam design industrial como um instrumento de sua estratégia global de crescimento. No planejamento corporativo, o design industrial desempenha um papel importante, coordenando as diversas manifestações de uma empresa no mercado e com o público em geral. Essas "mensagens" que constroem a imagem da empresa podem ser emitidas por produtos, arquitetura interior e exterior, embalagens, gráficos de estagnação, veículos, publicidade etc. Esses elementos em conjunto criam o chamado estilo da casa ou estilo corporativo.

O design industrial nos países industrializados encontra-se em uma situação na qual a relação entre os meios (tecnologia) e as necessidades (demanda) é precisamente a oposta à dos paises em desenvolvimento. Nos primeiros, o volume de necessidades é menor do que o volume das forças ou meios produtivos, ao passo que nos paises em desenvolvimento o volume de necessidades é maior do que a capacidade das forças produtivas.

(b) A abordagem diferente do design industrial nos países em desenvolvimento A diferença fundamental entre esses dois contextos opostos implica, naturalmente, em uma abordagem diferente de design industrial pelos paises em desenvolvimento. A abordagem diferente pode ser descrita como segue:

(i) Sobre a importância atribuida aos aspectos formais: embora indubitavelmente importantes, e dificilmente eliminados de qualquer esforço de design 
industrial, fatores formais desempenham um papel secundário nos países em desenvolvimento em comparaçäo aos paises industrializados, que podem se dar ao luxo de satisfazer demandas de inovação e sofisticaçẫo estéticas. Assim, o "bom design" tem lugar secundário nos paises em desenvolvimento, a menos que o mercado de exportação seja visado.

(ii) Sobre custos: se o design industrial visa à satisfação das necessidades das maiorias pobres, ele é exposto a constrangimentos econômicos pesados. Portanto, o problema é: como obter um bom, e näo simplório, valor de uso com baixo custo e baixo preço! $\mathrm{Em}$ geral, a flexibilidade da faixa de preço nos países industrializados é maior do que nos países em desenvolvimento.

(iii) Sobre recursos tecnológicos: em razão da falta de infraestrutura tecnológica, a gama de materiais, processos de fabricação e mão de obra qualificada, sobre os quais o designer industrial pode se apoiar, é bastante limitada. $\mathrm{O}$ design industrial nos paises em desenvolvimento é forçado a trabalhar sob condiçōes "imperfeitas" e limitadas.

(iv) Sobre volume de produção: os paises em desenvolvimento frequentemente têm mercados bastante limitados, enquanto os paises industrializados podem contar com enormes mercados. $\mathrm{O}$ uso de certas tecnologias é apenas econômico quando há uma grande oferta e um mercado potencial que possa absorver os produtos. $O$ design industrial nos paises em desenvolvimento deve, portanto, considerar suas limitaçōes de mercado e possiveis economias de escala.

(v) Sobre valor de uso: a escassez de meios impõe a busca por um máximo de valor de uso para um mínimo relativo dos custos. Isso não significa design de produtos mais baratos. Designs "baratos" não são necessariamente produtos com menor custo. Muitas vezes eles são o resultado de falsas economias.

(vi) Sobre utilização de recursos: os recursos limitados de países em desenvolvimento requerem uma abordagem racional, que garanta a sua utilização otimizada. A preocupação com o benefício social total das atividades de design é um pré-requisito. Qualquer erro cometido neste campo pesa muito mais do que nos paises industrializados.

(vii) Sobre implicações econômicas: os países ainda não industrializados têm também a possibilidade, pelo menos teoricamente, de optar por um padrão diferente de industrialização, que preste atenção à ecologia e que contenha medidas preventivas inerentes contra a liquidação do meio ambiente.

(viii) Sobre problemas alimentares: as populações de grande parte dos paises em desenvolvimento não recebem alimento suficiente, nem em quantidade nem em qualidade, especialmente alimentos ricos em proteínas. 
A imaginação e o esforço do design podem se concentrar na soluçāo deste problema básico: produção e conservação de mais e melhores alimentos para centenas de milhōes de pessoas. 0 design industrial pode contribuir para a solução do problema por meio do desenvolvimento de ferramentas adequadas e máquinas para a agricultura e, no futuro, talvez de aquicultura ou outras dessas inovaçōes.

\section{Definições para grupos de trabalho em desenvolvimento}

$O$ design industrial torna-se mais eficaz quando incluido como parte de uma equipe de desenvolvimento de produtos. Com a crescente complexidade dos problemas de design, torna-se cada vez mais necessário o trabalho em equipes interdisciplinares. A prática de empregos "um homem certo para o posto" é adequada apenas para problemas de baixa complexidade.

Uma equipe de desenvolvimento de produtos é composta geralmente por representantes

das ciências de engenharia,

das ciências comportamentais,

das ciências de gestāo,

do marketing,

do design industrial,

dos consumidores,

dos trabalhadores.

Por exemplo, quando o problema é design de equipamento hospitalar, médicos e pessoal técnico de hospitais devem ser incluídos na equipe; ou, no caso de design de máquinas agrícolas, a colaboração dos agrônomos não pode ser perdida.

Além disso, outros participantes podem ser representantes do patrocinador do projeto, por exemplo, oficiais de exportação, oficiais de ministérios da indústria etc.

Existem quatro diferentes configurações institucionais nas quais o design industrial pode ser exercido como uma profissão:

1. Estúdios de design industrial privados (design autônomo).

2. Design industrial como parte ou equipe de desenvolvimento de produtos em uma empresa de manufatura.

3. Design industrial exercido em uma faculdade de uma universidade.

4. Design industrial em um instituto ou agência governamental, de preferência com participação da indústria. 
A primeira alternativa requer um certo volume de demanda por design industrial e recursos financeiros nas indústrias. Muitas vezes, pequenas e médias indústrias, que prevalecem em países em desenvolvimento, não têm condições de investir em inovação tecnológica. A existência de estúdios de design autônomos pode não ser possivel dentro da estrutura comercial de um pais em desenvolvimento.

A segunda alternativa só é viável para uma empresa que possa financiar uma equipe interna permanente para o desenvolvimento de produtos. Uma equipe desse tipo requer um certa "massa crítica" antes que possa se tornar efetiva, caso contrário não irá funcionar em uma base interdisciplinar. Embora essa massa crítica possa não ser grande, a exigência existe, mas pode ser superada pela formação adequada de designers da disciplina apropriada.

A terceira alternativa sofre com a dificuldade de associar as universidades a problemas imediatos e urgentes da indústria, que muitas vezes precisam de equipes internas. A organização de uma faculdade ou departamento que trate de design industrial ou desenvolvimento de produtos, em geral, deve ser muito flexível, a fim de permitir um trabalho eficaz.

A quarta alternativa parece ser a forma mais promissora de organizar grupos de trabalho de design industrial em países em desenvolvimento. Como já foi mencionado antes, indústrias de pequena e média escala geralmente não têm orçamento suficiente para financiar atividades de design industrial como parte da inovação tecnológica. Muitas vezes, elas não consideram como sua a tarefa de investir em inovação tecnológica. Nesse caso, é o governo quem pode assumir a responsabilidade de promover e financiar atividades de design industrial. $\dot{\mathrm{E}}$ também nesse nível que organismos internacionais podem se tornar eficazes.

Dependendo de situações especificas, atividades de design industrial poderiam ser exercidas sob a responsabilidade do ministério da economia, ou do ministério de comércio exterior, ou do ministério da indústria. Além disso, poderiam ser criadas equipes de desenvolvimento de produtos especializadas para certos setores de produtos, como agricultura, habitação e saúde.

\section{Promoção do design industrial}

\section{(a) Informações}

Uma vez que o design industrial deve ser utilizado como uma ferramenta para o desenvolvimento, o primeiro pré-requisito a ser cumprido é clarear as ideias sobre o papel e a função do design industrial.

Por conseguinte, o primeiro passo da introdução e/ou da promoção do design industrial consiste em tornar disponíveis informações sobre a natureza da atividade.

Sem informações sobre design industrial, não pode haver objetivos bem definidos para programas de assistência e políticas em design.

A informação deve ser voltada para: 


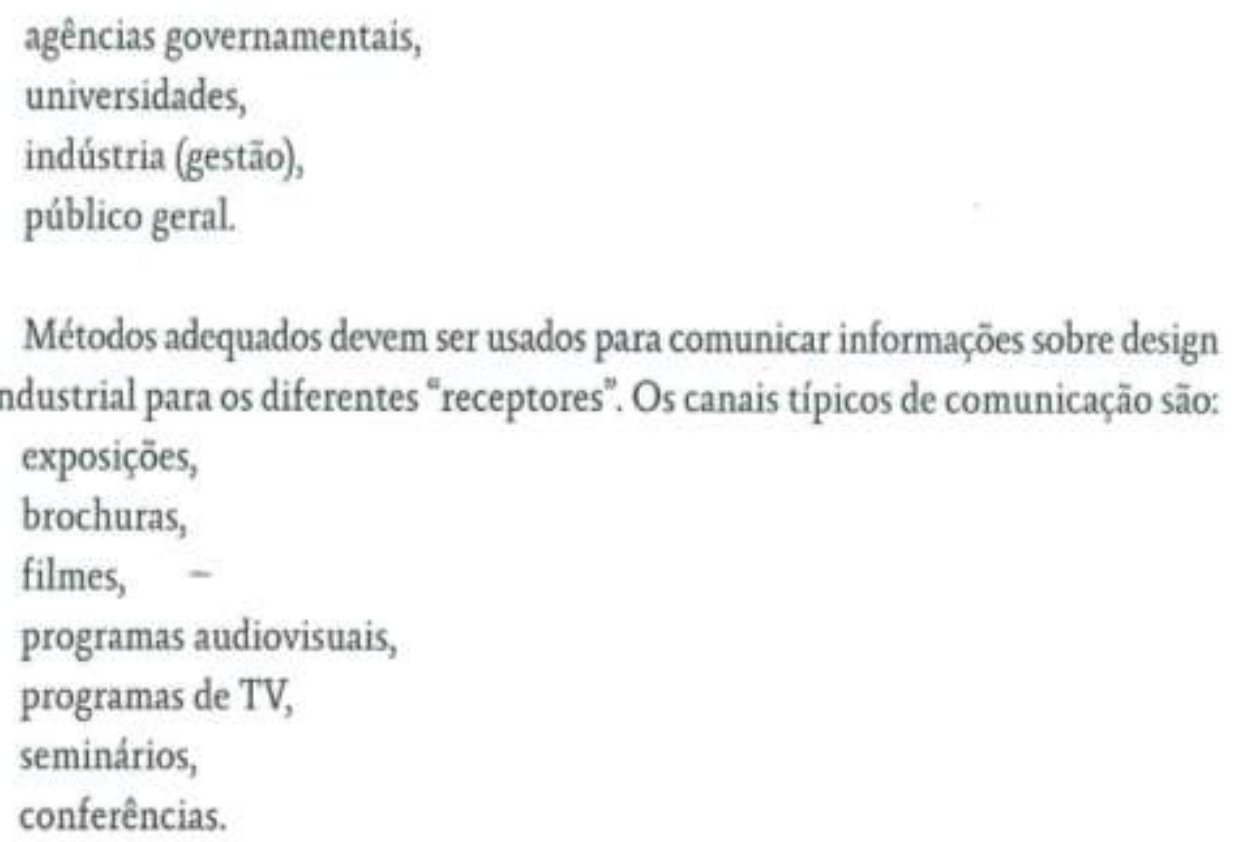

A informação deve ser orientada para os interesses especificos dos espectadores e abrange os seguintes itens:

1. História do design industrial.

2. Definição de design industrial.

3. Funções e objetivos do design industrial.

4. Definições institucionais.

5. Método de trabalho (metodologia) do design industrial.

6. Estudos de caso sobre desenvolvimento de produtos.

7. Fontes ou informaçōes sobre desenho industrial (bibliografia).

8. Prática profissional.

9. Educação dos designers industriais.

\section{(b) Apoio logístico à promoção e à informação do design}

Em muitos países industrializados, os governos criaram centros de design. Sua finalidade é basicamente a promoçăo do design, e eles utilizam os métodos a seguir:

1. Organização de exposições.

2. Organização de mostras permanentes de produtos selecionados.

3. Organização de índices de design (informações detalhadas sobre produtos de diversos setores industriais).

4. Organização de conferências.

5. Organização de premiaçöes anuais a realizações no campo do design industrial. 
6. Organização de seminários e workshops de design.

7. Organização de uma biblioteca especializada.

8. Organização de uma coleção de slides.

9. Publicação de um periódico sobre design industrial.

Além disso, esses centros de design podem trabalhar como consultores para a indústria e como pontos de articulação para entrar em contato com as organizações internacionais, como o ICSID.

Além dessas duas funções principais, informar e promover centros de design industrial pode gerar serviços de design industrial. Esse ponto é muito importante para os países em desenvolvimento, porque a promoção do design sem o oferecimento de serviços de design poderia facilmente causar frustrações e até mesmo ter efeitos contraproducentes. A indústria pode reconhecer o papel do design industrial e estar disposta a introduzi-lo em suas políticas; mas isso requer a disponibilidade de designers industriais.

\section{(c) Formação de designers industriais}

Uma das principais desvantagens de países em desenvolvimento consiste na falta de mão de obra qualificada em design industrial. Portanto, alta prioridade deve ser atribuída à formação de designers industriais nos países em desenvolvimento. Programas e projetos de desenvolvimento industrial devem atender a essa necessidade.

Hoje, não existe consenso geral sobre a questão de onde o design industrial deve ser ensinado. Até que exista uma universidade de design, que "abrace todas as especializações do design" (tanto vertical quanto horizontalmente), cada solução será apenas um "remendo".

O design industrial é ensinado, hoje, nas seguintes instituições:

Academias de Belas Artes,

Escolas de Artes Aplicadas,

Departamentos ou faculdades de Arquitetura,

Institutos de tecnologia (geralmente como uma matéria do curso de engenharia mecânica),

Escolas politécnicas,

Escolas ou institutos de design,

Faculdades ou departamentos de design ambiental.

Conteúdo (currículo), métodos de ensino (didática) e orientações gerais de design industrial na educação ainda são questões controversas que terão de ser resolvidas no futuro. Mas, levando em conta que o design industrial é uma profissão exercida 
em um ambiente tecnológico (indústria), ele também deve ser ensinado em um ambiente educacional técnico e cientifico, com orientação correspondente. Só assim ele pode se tornar uma ferramenta séria e eficaz para o desenvolvimento.

Embora se saiba que o treinamento em design está em processo de evolução, os países em desenvolvimento devem participar de cursos existentes, a fim de garantir que os currículos cheguem ao ponto de incluir seus requisitos, bem como os dos países desenvolvidos.

Bolsas de estudo dadas para estudantes de paises em desenvolvimento, a fim de estudar nos países industrializados, podem ser úteis até certo ponto, quando esses estudos estão ligados a problemas específicos que precisam ser resolvidos nos países em desenvolvimento, por exemplo, design de máquinas agrícolas. A esse respeito, as instituições de ensino dos paises industrializados não estão bem preparadas, pois programas de estudo não podem (e dificilmente conseguem) atualmente corresponder às necessidades $\mathrm{e}$ às realidades dos países em desenvolvimento. Programas de estudo de desenho industrial que fingem "ajudar" o mundo em desenvolvimento têm, no melhor dos casos, uma função ideológica e servem mais para apaziguar a consciência pesada ou o descontentamento com a sociedade de consumo dos estudantes e professores nos países industrializados. Seu valor prático para os países em desenvolvimento é nulo, porque soluções de design para os paises em desenvolvimento só podem ser encontradas e trabalhadas dentro dos países em desenvolvimento, e näo ser importadas do exterior.

Além disso, pode ocorrer que o estudante fique alienado de seu próprio país, cedendo às tecnologias avançadas e às condiçōes de trabalho dos países industrializados.

(d) Design Industrial em programas de assistência técnica

Agências internacionais como a UNIDO, preocupadas com o desenvolvimento industrial, podem se tornar um instrumento eficaz para introduzir e implementar atividades de design industrial em países em desenvolvimento por meio da iniciação de programas adequados.

No âmbito desses programas de desenvolvimento industrial, designers industriais poderiam contribuir com o seu conhecimento em diferentes fases do processo de desenvolvimento do produto, por exemplo:

(i) Detecção e formulação de necessidades. Definição de uma política de design industrial para determinados ramos industriais.

(ii) Formulação de um cronograma de tarefas de design, com especificações de desempenho e restrições financeiras, tecnológicas, sociais e culturais que definam o espaço de decisão no qual a solução de design tem de ser encontrada. 
(iii) Análise das soluçōes de design existentes e avaliação.

(iv) Desenvolvimento de possíveis alternativas básicas para resolver o problema.

(v) Avaliação crítica e seleção da alternativa mais promissora (ou alternativas).

(vi) Detalhamento da alternativa selecionada em termos de detalhes ergonômicos, técnicos e formais: acabamento, cor, produtos gráficos etc.

(vii) Construçāo de modelos e protótipos.

(viii) Adaptação da proposta de design para a criação de instalações particulares de produçẫo.

Ao trabalhar na solução dos verdadeiros problemas de design em países em desenvolvimento, o especialista em design industrial deveria treinar equipes homólogas.

Além disso, ele pode dar palestras de valorização do design industrial e cursos para outras profissões relacionadas, como engenharia e gestão. Pode também dar sua contribuição para o estabelecimento de oficinas de protótipos e a promoçã̃o do design industrial.

Além da assistência a projetos de design, deve ser colocada ênfase na gestão e na pesquisa de design. Todas as três especializaçōes dentro da área de design industrial devem ser promovidas, pois elas dependem mutuamente uma da outra.

A gestão do design sem projetos de design torna-se um mero passatempo burocrático.

A pesquisa de design sem projetos de design torna-se um mero passatempo acadêmico.

Projetos de design sem pesquisa e gestão se tornam mera rotina de trabalho sem inovação e implementação.

\section{O papel do ICSID}

O ICSID (Conselho Internacional de Sociedades de Design Industrial), como uma organização que representa entidades profissionais de paises de todo o mundo, poderia oferecer assistência à UNIDO nas seguintes áreas:

(i) Preparação de material de informação e promoção sobre design industrial para os países em desenvolvimento.

(ii) Elaboração de programas e projetos de desenvolvimento de design industrial.

(iii) Organização de seminários sobre design industrial nos paises em desenvolvimento.

(iv) Transmissão de solicitações por pessoal especializado para as sociedades nacionais de design industrial. 
(v) Estabelecimento de contato com especialistas de países ainda não formalmente representados no ICSID, e informação à UNIDO sobre a situação do design industrial nesses países.

(vi) Informação à ONUDI sobre ensino e cursos de design industrial que possam ser úteis para estudantes de países em desenvolvimento.

(vii) Coordenação das informaçōes sobre projetos de design industrial e pesquisas relevantes na área para os paises em desenvolvimento.

(viii) Preparação de literatura técnica especializada sobre design industrial. 
Anexo 2:

Organização das Nações Unidas para o Desenvolvimento Industrial

Distr.

Restrito

UNIDO/ITD.326

17 de março 1975 


\section{ORGANIZAÇÃO DAS NAÇÕES UNIDAS PARA O DESENVOLVIMENTO INDUSTRIAL Distr. RESTRITO \\ UNIDO/ITD.326 17 de março 1975}

ISENÇĀO DE RESPONSABILIDADE: Este documento foi produzido sem edição oficial das Naçōes Unidas. As designaçōes empregadas e a apresentação do material neste documento nāo implicam a expressão de qualquê opiniāo por parte do Secretariado da Organização das Naçōes Unidas para o Desenvolvimento Industrial (UNIDO), relativa ao estatuto legal de qualquer país, território, cidade ou região ou de suas autoridades, ou relativamente à delimitação das suas fronteiras ou limites, ou seu sistema econômico ou grau de desenvolvimento. Designaşōes, como "desenvolvido", "industrializado" e "em desenvolvimento" destinam-se à conveniência estatística e não expressam necessariamente um julgamento sobre o estágio alcançado por um determinado pás ou regiäo no processo de desenvolvimento. A menção de nomes de empresas ou produtos comerciais não constitui um endosso pela UNIDO. 


\section{Sumário}

\section{INTRODUÇÃO}

2. GRUPO A - O lugar do design industrial no desenvolvimento Recomendação 1-Design industrial como componente de inovação tecnológica Recomendação 2 - Localização do design industrial em programas de assistência tecnológica

Recomendação 3 - Design industrial como atividade de planejamento

Recomendação 4 - Política de diversificação de produtos Recomendação 5 - Transferência de tecnologia

3. GRUPO B - Objetivos e requerimentos, e áreas de atuação

Recomendação 6-Desenvolvimento de produtos para os mercados locais Recomendação 7 - Designn para substituiçãa de importações

Recomendação 8 - Design para mercados de exportação

Recomendação 9 -Designs de trabalho intensivo

Recomendação 10 - Design para produção alimentícia

Recomendação 11 - Compatibilidade ambiental

Recomendação 12 - Tecnologia "apropriada"

Recomendação 13- Utilização de capacidades de produção existentes

4. GRUPO C - Componentes dos programas de desenvolvimento do design industrial

Recomendação 14-Criação de centros de desenvolvimento de produtos

Recomendação 15 - Direitos autorais do design

Recomendação 16 - Treinamento de capacidades locais de design

Recomendação 17 - Promoção do design industrial

Recomendação 18 - Informação sobre design industrial 


\section{Introdução}

As recomendações presentes neste documento são resultado de uma reunião conjunta entre oficiais da UNIDO, de outras agências internacionais e de instituições nacionais preocupadas com os países em desenvolvimento, e membros do ICSID (Conselho Internacional de Sociedades de Design Industrial). O encontro foi realizado no início de junho de 1973 em Viena, onde foi decidida a elaboração deste documento. Como será visto, o design industrial constitui um instrumento indispensável para a industrialização dos países em desenvolvimento.

$\mathrm{O}$ documento consiste em um conjunto de recomendações que pretendem funcionar como diretrizes a partir das quais um programa integrado de design industrial e desenvolvimento de produtos para países em desenvolvimento possa ser formulado.

Em razão do fato de que o contexto específico de cada país em desenvolvimento difere vastamente - por exemplo, em nível tecnológico, grau de industrialização, recursos naturais, condições climáticas, força de trabalho, tradições culturais e tipo de economia - seria autodestrutivo tentar formular uma política específica a ser aplicada indistintamente em todos os países em desenvolvimento.

Logo, este documento oferece apenas um conjunto de recomendações a partir das quais políticas especiais possam ser derivadas.

As recomendações foram divididas em três grupos distintos, a saber:

GRUPO A: As recomendações de 1 a 5 definem o lugar do design industrial no desenvolvimento de uma planta geral de industrialização.

Grupo B: As recomendações de 6 a 13 definem os objetivos, requerimentos e áreas de atuação que deveriam ser considerados apropriados para enfatizar a elaboração de programas de design industrial particulares.

Grupo C: As recomendaçōes de 14 a 18 definem os componentes a partir dos quais um programa específico de desenvolvimento do design industrial possa ser composto de acordo com as necessidades particulares de um país ou região.

\section{GRUPO A - O lugar do design industrial no desenvolvimento}

Recomendação 1 - Design industrial como componente de inovação tecnológica

O design industrial deve ser considerado e promovido como um componente da inovação tecnológica, especialmente como uma disciplina do desenvolvimento de produtos.

O processo de desenvolvimento de produto está preocupado com usabilidade, produtividade, comerciabilidade, lucratividade e qualidade formal (ou estética) de um produto.

Usabilidade refere-se à relação entre usuário e produto, o que implica que o produto deve ser prático, seguro, fácil de usar, e de simples manutenção e reparo. A usabilidade leva em conta também fatores ergonômicos, como requisitos antropométricos. 
Produtividade refere-se ao uso adequado dos recursos tecnológicos, compreendendo estoque de maquinários, materiais disponiveis, habilidades e experiência da força de trabalho, conhecimento dos processos de fabricação e métodos organizacionais.

Comerciabilidade refere-se à demanda potencial de um consumidor ou comprador por um produto, não sendo necessariamente um indivíduo, mas podendo ser também uma agência governamental ou da administração pública.

Lucratividade refere-se à manufatura no sentido de proporcionar um valor de uso adequado a custos razoáveis, levando em consideração a disponibilidade de trabalho $\mathrm{e}$ as habilidades potenciais.

Qualidade formal ou estética refere-se às propriedades visuais e ópticas de um produto, à coerência das partes que constituem a forma global de um produto - textura, cor, acabamento.

Assim, está relacionada a contexto cultural, padrões sociais e comportamento dos usuários/compradores de um produto.

\section{Recomendação 2 - Localização do design industrial em programas de assistência tecnológica}

A atividade de design industrial deve ser incluida em programas gerais de industrialização, uma vez que o design industrial é um instrumento essencial de desenvolvimento. Logo, ao formular programas e projetos relacionados a indústrias de fabricaçâo de bens de capital, bens de consumo, embalagens e componentes de construção, o design industrial deve ser incluído na medida em que desempenha um papel importante no desenvolvimento de indústrias manufatureiras.

\section{Recomendação 3 - Design industrial como atividade de planejamento}

O design industrial complementa disciplinas já existentes, como economia, engenharia etc., envolvidas com o processo de planejamento industrial ao trazer ao foco de interesse considerações quanto à qualidade dos produtos, à política de diversificação, à padronização, ao potencial de exportação etc.

Assim, quando um país em desenvolvimento está interessado em utilizar o design industrial como um fator de industrialização, seus designers industriais devem ser introduzidos às equipes de planejamento pertinentes no nivel correspondente de poder de decisão.

Recomendaçảo 4 - Politica de diversificação de produtos Em face dos recursos limitados de trabalho e especialmente de capital, o uso racional dos meios disponiveis torna-se pré-requisito, e a definição de prioridades, inevitável. Desse modo, o designer industrial deve contribuir para a formulação de políticas de diversificaçäo de produtos nos países em desenvolvimento. 


\section{Recomendação 5 - Transferência de tecnologia}

Quando a tecnologia, em forma de produtos ou técnicas, é transferida para um país em desenvolvimento, o designer industrial deve participar da avaliação das alternativas oferecidas e contribuir para a formulação de recomendaçōes à agência governamental responsável pela importação da tecnologia. Assim, designs de produto e tecnologia apropriados podem ser mais bem avaliados em relação à cultura $\mathrm{e}$ às necessidades do país.

\section{GRUPO B - Objetivos e requerimentos, e áreas de atuação}

Recomendação 6 - Desenvolvimento de produtos para os mercados locais

Se a satisfação da demanda local é o objetivo do governo de um país em desenvolvimento, as necessidades reais de todos os estratos sociais devem ser estudadas cuidadosamente, e a criação de soluções de design deve ser estimulada, levando em conta restrições tecnológicas, culturais e econômicas.

Uma análise cuidadosa pode revelar que soluções completamente novas teriam de ser desenvolvidas, para as quais não existe nenhuma experiência comparável nos países desenvolvidos.

Deve ser dada ênfase ao design de produtos para a população rural, que geralmente constitui a maioria esmagadora da população dos paises em desenvolvimento.

Isso é particularmente um processo inovador de design.

Recomendação 7 - Design para substituição de importações

A substituição de importações como uma política formulada nos anos 1950 nem sempre levou aos efeitos econômicos esperados. Ela favoreceu, principalmente, produtos de consumo fabricados por indústrias leves. Além disso, essa política geralmente é orientada para a tentativa de substituir bens que foram projetados para satisfazer às necessidades de paises já industrializados, que não são necessariamente idênticas àquelas dos países em desenvolvimento.

As áreas nas quais os serviços de design industrial são utilizados devem, então, ser estendidas para encorajar a inovaçẫo não apenas no campo das indústrias leves, mas também das médias e pesadas.

Recomendação 8 - Design para mercados de exportação

O design industrial é uma ferramenta essencial para a promoção da exportação, e ênfase deve ser dada, então, a uma estratégia de inovação, como também à concorrência com tipos de produtos e mercados já "ocupados".

A promoção da exportação não deve ser apenas direcionada a economias industrializadas, mas também a áreas regionais cujos membros tenham estabelecido acordos comerciais entre eles. 
Recomendação 9 - Designs de trabalho intensivo

Nos lugares onde a criação de empregos produtivos é pré-requisito, as políticas de desenvolvimento de produtos devem considerar o design de produtos de trabalho intensivo. No entanto, uma abordagem muito rigida e unilateral deve ser evitada. O critério principal a ser considerado em decisões a respeito da conveniência do desenvolvimento de designs de trabalho intensivo são as habilidades disponíveis, o potencial de treinamento da mão de obra e os efeitos comparativos sobre o rendimento nacional de investimentos em tecnologias baseadas em capital ou trabalho intensivo.

\section{Recomendação 10 - Design para produção alimenticia}

- Geralmente, uma grande parte da população dos países em desenvolvimento não recebe alimento suficiente, nem em quantidade nem em qualidade, especialmente alimentos ricos em proteínas. Para resolver esse problema básico, programas de desenvolvimento de produtos devem incluir o design de utensilios para produção, conservação e distribuição de alimentos.

Recomendação 11 - Compatibilidade ambiental

Programas de desenvolvimento de produtos devem levar em conta fatores ambientais: de um lado, problemas de recursos, de outro, problemas de poluição. Assim, a busca por fontes não convencionais de energia (vento, raios solares) em relação a certos produtos e o design de reúso de produtos e materiais devem ser incentivados.

\section{Recomendação 12 - Tecnologia "apropriada"}

Esforços de design devem ser ligados ao desenvolvimento de tecnologias "apropriadas". Esse termo implica uma tecnologia voltada para as habilidades existentes e potenciais e a necessidade de desenvolvimento do país em questão, e não apenas um tipo de tecnologia que foi utilizado há 30, 40 anos ou mais em países desenvolvidos durante seu período de desenvolvimento.

Em alguns casos, a tecnologia "apropriada" pode ser a tecnologia mais avançada à disposição.

Recomendação 13 - Utilização de capacidades de produção existentes Preferencialmente, deve ser dada ênfase a programas que não requerem grandes quantidades de investimento monetário, mas que se apoiam na utilização e/ou melhoria das instalações e métodos de produção presentes.

Frequentemente, a capacidade de design local, os designs desenvolvidos localmente e a tecnologia local são subestimados pelos próprios países em desenvolvimento. Desse modo, programas de desenvolvimento industrial devem ser sensiveis 
aos métodos de produção e ao design locais e tentar conservá-los ou melhorá-los, uma vez que métodos e designs desenvolvidos ao longo de décadas podem ser mais adequados às necessidades locais e capazes de se estender para a produção mais elevada necessária ao desenvolvimento de mercado.

\section{GRUPO C: Componentes dos programas de desenvolvimento do design industrial}

Recomendação 14 - Criação de centros de desenvolvimento de produtos

Centros de desenvolvimento de produtos devem ser organizados o quanto antes na área de desenvolvimento industrial, com uma base multidisciplinar que incorpore engenharia, marketing etc., todos componentes do design industrial. Os centros devem ser equipados com escritórios de design, oficinas para construção de protótipos e modelos, testes de protótipos, e instalações para treinamento e seminários, e devem fornecer serviços de informação industrial.

Os centros cumpririam as funções descritas nas Recomendações 15 a 18, a seguir.

Quando um país em desenvolvimento considerar apropriado, um relatório diagnóstico deve ser feito, preferencialmente por uma equipe de pesquisa formada por um especialista ou um grupo de especialistas estrangeiro, em conjunto com parceiros nacionais. $\mathrm{O}$ relatório deve servir de base para um programa de assistência técnica onde isso for considerado desejável.

Recomendação 15 - Direitos autorais do design

Quando uma base técnica para atividades inovadoras de design é criada em países em desenvolvimento, é necessário também elaborar procedimentos que garantam os direitos autorais dos designs desenvolvidos localmente. Assim, a formulação de normas de proteção ao design será necessária.

Recomendação 16 - Treinamento de capacidades locais de design $\mathrm{O}$ aumento da capacidade local de inovação deve ser incentivado. Países em desenvolvimento devem se tornar autossuficientes em design o mais rápido possivel. A fim de treinar a força de trabalho local, os seguintes passos devem ser seguidos:

1. Unir parceiros locais a especialistas estrangeiros em um programa de desenvolvimento de produto.

2. Criar oficinas locais, regionais e internacionais de design, nas quais designers de diferentes países em desenvolvimento possam trocar suas experiências.

3. Oferecer bolsas de estudo a alunos de países em desenvolvimento em instituições de países desenvolvidos, de modo a melhorar seus conhecimentos. Contudo, o programa dessa instituição deve ser voltado aos problemas dos países em desenvolvimento. 
4. Oferecer excursôes de estudo a designers em regiōes e paises apropriados, buscando a revisäo de métodos e treinamento de design e de exigências de produto.

Deve-se tomar cuidado para que os programas de treinamento nầo resultem na negligência pelos designers de sua própria cultura, em razâo da ênfase àquelas dos paises onde o treinamento é realizado.

\section{Recomendação 17 - Promoção do design industrial}

A fim de promover o design industrial local, os seguintes passos devem ser seguidos:

i. Organização de uma exposiçảo itinerante que será apresentada nas unidades de produção dos paises interessados, a fim de instigar o interesse de administradores, equipe técnica e trabalhadores em geral. 0 material deve enfatizar o processo de design, em vez do resultado.

ii. Preparação de uma brochura curta e de alto impacto, dirigida a decisores políticos de alto escalão dos paises em desenvolvimento.

iii. Preparação de um documento mais detalhado, direcionado aos conselheiros de decisores politicos de alto escalão.

iv. Preparação de um material de favorecimento do design, na forma de filme ou programa audiovisual.

v. Organização de uma premiação internacional de design na forma de bolsas de estudo para designers industriais de paises $\mathrm{em}$ desenvolvimento.

\section{Recomendação 18 - Informação sobre design industrial}

A fim de preencher as lacunas de informação, os seguintes passos devem ser seguidos:

i. Coleçâa e disseminação de estudos de caso de projetos de design, principalmente de paises em desenvolvimento (tanto com resultados positivos quanto negativos, explicando, no segundo caso, a razão do fracasso).

ii. Construção de um sistema de informações, em nivel nacional, regional e internacional, sobre questōes relevantes para o design, por exemplo, listas de projetos de desenvolvimento de produtos em execuçảo, lista de projetos de desenvolvimento de produtos concluidos, lista de projetos de pesquisa relevantes para o design em instituiçôes governamentais, públicas e possivelmente privadas, tanto nos paises desenvolvidos como nos em desenvolvimento.

iii. Construir e disseminar uma bibliografia classificada sobre design industrial para paises em desenvolvimento.

iv. Construir e disseminar uma bibliografia comentada sobre design. 
v. Elaborar e disseminar uma lista de filmes sobre design industrial e assuntos relacionados.

vi. Produzir um manual técnico de design industrial para paises em desenvolvimento.

vii. Construir e tornar acessível um arquivo de slides sobre design industrial.

viii. Elaborar uma lista de designers cuja experiência possa ser útil na solução de problemas de países em desenvolvimento.

ix. Disseminar conhecimento sobre tecnologias de baixo custo. 